\title{
POLIMENTO DE ROCHAS ORNAMENTAIS: UM ENFOQUE TRIBOLÓGICO AO PROCESSO
}

\section{LEONARDO LUIZ LYRIO DA SILVEIRA}

Tese apresentada à Escola de Engenharia de São Carlos, da Universidade de São Paulo, como parte dos requisitos para a obtenção do título de Doutor em Geotecnia.

ORIENTADOR: Prof. Dr. José Eduardo Rodrigues

\section{São Carlos/SP}


Dedica este trabalbo a Alice e wa Tutu. At duas pessoas mais importantes da minka vida. 


\section{AGRADECIMENTOS}

Ao Conselho Nacional de Desenvolvimento Científico e Tecnológico (CNPq) pela bolsa de estudos.

Ao Prof. Dr. José Eduardo Rodrigues pela orientação da minha pesquisa e pela grande ajuda dada nos momentos mais difíceis.

Ao Prof. Dr. Antenor Braga Paraguassú pelo companheirismo, amizade e ajuda dada em todos os aspectos, no período da minha vida passada nesta cidade.

Aos Professores Doutores Lázaro Valentin Zuquette e Benedito de Souza Bueno pelos conselhos em um dos momentos mais difíceis que tive nesses quatro anos.

Ao Prof. Dr. Antônio Carlos Artur pela grande ajuda dada ao longo de toda a pesquisa.

Ao Prof. Dr. Benedito Di Giacomo pelo grande auxílio dado no laboratório de Metrologia do Departamento de Engenharia Mecânica.

Ao Prof. Dr. Ely Borges Frazão pelas sugestões dadas, principalmente na minha qualificação.

Ao Prof. Dr. Casteletti pela disposição na parte de imageamento de todas minhas amostras realizadas no Departamento de Engenharia de Materiais.

Ao Prof. Dr. Rollo do Departamento de Engenharia de Materiais pelas conversar em empréstimo de material bibliográfico.

Ao Centro Tecnológico do Mármore e do Granito (Cetemag) na pessoa da Sra. Olívia Tirello por toda a ajuda dada desde o início de minha pesquisa.

Ao Centro de Tecnologia Mineral (CETEM) na figura do Prof. Dr. Adriano Caranassius pela trocas de idéias e sugestões dadas ao trabalho.

A empresa Granita Ltda. pelo fornecimento de parte das amostras necessárias para a realização do trabalho. 
A empresa Monte Sião Granitos Ltda. pelo fornecimento do restante do material utilizado na pesquisa.

A empresa Cobral Abrasivos Ltda. pela doação dos abrasivos utilizados neste trabalho.

A minha querida esposa Alice Bonatto de Castro da Silveira pela ajuda na revisão final do trabalho.

A União de Ensino São Francisco (UNESF), na figura do diretor Claudemar Fiorotte por sempre me apoiar em todos os aspectos de minha vida acadêmica e profissional.

Aos meus alunos do Curso de Tecnologia em Rochas Ornamentais pela paciência e pelo carinho a mim dispensados desde o início.

Aos colegas de trabalho, em especial Isaura Regadas, Clébio Goulart, Rogério Ribeiro, pela amizade e ajuda ao logo de todo o trabalho.

Aos colegas de república Éder cabra, Júlio Zambrano, Júlio Fialho, Cleber e Ivan, pelo apoio logístico e companhia nas minhas idas e vindas.

Aos funcionários do Departamento de Geotecnia Herivelto, Maristela, Neiva, Álvaro, Toninho, Zé papão, "Seu” Antônio, Dito Cujo e Oscar pelo tanto que me ensinaram e pela amizade.

A todas as pessoas que de alguma forma colaboraram para que este trabalho chegasse ao fim. 
SUMÁRIO

Lista de Figuras $\mathrm{i}-\mathrm{xi}$

Lista de Tabelas xii

Lista de Quadros xiii

Resumo xiv

Abstract XV

1. INTRODUÇÃO 01

1.1. PANORAMA GERAL DO SETOR 01

1.2. OBJETIVO 03

2. REVISÃO BIBLIOGRÁFICA 04

2.1 BRILHO 04

2.1.1. PROPRIEDADE ÓPTICA 04

2.1.1.1. INTERAÇÕES DA LUZ COM SÓLIDOS 04

2.1.1.2 PROPRIEDADES ÓPTICAS DE MINERAIS NÃO-METÁLICOS 06

2.1.2. A QUALIDADE DO BRILHO DE CHAPAS DE ROCHA POLIDA 11

2.1.2.1 FATORES NO POLIMENTO DE ROCHAS ORNAMENTAIS 11

2.1.3 TÉCNICAS DE MEDIÇÃO DO BRILHO EM SUPERFÍCIES 16

2.2. DESGASTE 21

2.2.1. INTRODUÇÃO A TRIBOLOGIA 21

2.2.2. TIPOS DE DESGASTE 22

2.2.3. TIPOS DE ABRASIVOS 25

2.2.3.1. PRINCIPAIS FATORES QUE INFLUEM NA ABRASIVIDADE_28

2.2.4. MODELOS ANALÍTICOS DO PROCESSO ABRASIVO 37

2.3. TECNOLOGIA DE BENEFICIAMENTO FINAL 39

2.4. CARACTERIZAÇÃO TECNOL. DE ROCHA PARA ENGENHARIA_44

2.4.1. CARACTERIZAÇÃO TECNOL. DE ROCHAS ORNAMENTAIS

E DE REVESTIMENTO 45

2.4.1.1. ANÁLISE PETROGRÁFICA (ABNT NBR 12768) 47

2.4.1.2. ÍNDICES FÍSICOS (ABNT NBR 12766) 51 
3. MATERIAIS E MÉTODOS 53

3.1. MATERIAIS ROCHOSOS ESTUDADOS 53

3.1.1 VERMELHO BRASÍLIA___ 53

3.1.2 PRETO INDIANO__ 58

3.1.3 CINZA CASTELO__ 62

3.1.4 DESERT STORM__ 66

3.1.5 VERDE LABRADOR__ 71

3.1.6 CAPÃO BONITO__ 74

3.2. DEFINIÇÃO DO TRIBOSSISTEMA___ 78

4 - RESULTADOS E DISCUSSÕES___ 82

4.1. RUGOSIDADE DAS SUPERFÍCIES DOS MATERIAIS ESTUDADOS 82

4.1.1. PRIMEIRA ETAPA (\#24 MESH)___ 83

4.1.2. SEGUNDA ETAPA (\#36 MESH)__ 90

4.1.3. TERCEIRA ETAPA (\#60 MESH)___ 96

4.1.4. QUARTA ETAPA (\#120 MESH)___ 102

4.1.5. QUINTA ETAPA (\#220 MESH)___ 109

4.1.6. SEXTA ETAPA (\#400 MESH)___ 115

4.1.7. SÉTIMA ETAPA (\#600 MESH)___ 122

4.1.8. OITAVA ETAPA (\#800 MESH)___ 128

4.1.9. NONA ETAPA (\#1200 MESH)___ 134

4.1.10. DÉCIMA ETAPA (LUSTRO)___ 141

4.2 MEDIÇÃO DO BRILHO DOS MATERIAIS ESTUDADOS___ 147

4.3 ENSAIO DE SIMULAÇÃO DE POLIMENTO DE ROCHA (SPR)___ 157

4.3.1. FUNDAMENTAÇÃO TEÓRICA___ 157

4.3.2. SIMULADOR DE POLIMENTO DE ROCHA - SPR__ 159

4.3.3. PERPARAÇÃO DOS CORPOS-DE-PROVA___ 163

4.3.4. PROCEDIMENTOS DO ENSAIO__ 165

4.4 TRATAMENTO DOS DADOS NO EQUIPAMENTO SPR___ 169

4.4.1. RELAÇÕES DE PERDA DE MASSA DE ROCHA

E DE ABRASIVO 169 
4.4.2. MEDIÇÃO DO BRILHO DOS CORPOS-DE-PROVA ENSAIADOS NO EQUIPAMENTO SPR 191

5. CONCLUSÕES 198

6. REFERÊNCIAS BIBLIOGRÁFICAS 199 


\section{LISTA DE FIGURAS}

Figura 2.1- Transmitância da luz exibida por três amostras de óxido de alumínio 05

Figura 2.2 - Equipamento para medição do brilho de placas polidas 14

Figura 2.3 - Relação de estágios de tratamento da placa de rocha e valores de brilho 14

Figura 2.4 - Fotografia em MEV mostrando a superfície de uma folha de aço 17

Figura 2.5 - Medidor de brilho (glossmeter) em ladrilho de granito 17

Figura 2.6 - Comparação entre uma sup. real e o perfil medido com ponta stylus 19

Figura 2.7 - Efeito de uma ponta stylus com defeito na medição da rugosidade 19

Figura 2.8 - Tipos de irregularidades de superficie 20

Figura 2.9 - Esquema de desgaste a dois e a três corpos 23

Figura 2.10 - Rel. entre o tamanho do abrasivo, tipo de desgaste e rugosid. média 24

Figura 2.11 - Rebolos abrasivos magnesianos utilizados no polimento de rochas 27

Figura 2.12 - Dois dos principais tipos de ponta utilizados para microindentação 30

Figura 2.13 - Realização da caracterização da microdureza em rochas ornamentais 31

Figura 2.14 - Comparação entre várias escalas de dureza 32

Figura 2.15 - Relação entre tamanho do grão abrasivo e taxa de remoção 34

Figura 2.16 - Relação entre tamanho do abrasivo e rugosidade máxima (Rmax) 35

Figura 2.17 - Tenacidade e fragilidade da partícula sobre influência em desgastar 36

Figura 2.18 - Modelo de desgaste abrasivo causado por uma única partícula 38

Figura 2.19 - Modelo de politriz manual 40

Figura 2.20 - Linha de produção em ladrilhos: da calibração ao polimento 41

Figura 2.21 - Exemplo de politriz de ponte móvel de um cabeçote 42

Figura 2.22 - Exemplo de politriz de ponte móvel de dois cabeçotes 42

Figura 2.23 - Exemplo de politriz de ponte móvel de três cabeçotes 42 
Figura 2.24 - Modelo de politriz automática multicabeças 44

Figura 2.25 - Relação ente razão quartzo/feldspato e peso específico aparente seco 48

Figura 2.26 - Relação entre resistência à compressão e a razão quartzo/feldspato 48

Figura 2.27 - Relação entre resistência à tração e a razão quartzo/feldspato 49

Figura 2.28 - Relação entre percentagens de minerais e a resistência à compressão 49

Figura 2.29 - Relação entre o tamanho máximo dos grãos e a resist. à compressão 50

Figura 2.30 - Compressão uniaxial vs tamanho médio dos grãos 50

Figura 3.1 - Granito Vermelho Brasília 54

Figura 3.2 - Fotomicrografia com a visão geral das rel. de contato entre os minerais 57

Figura 3.3 - Fotomicrografia mostrando plagioclásio pigmentado por óxidos 57

Figura 3.4 - Fotomicrografia contendo microclínio com argilomineralização 58

Figura 3.5 - Gnaisse Preto Indiano 58

Figura 3.6 - Fotomicrografia com biotita separadas por porções granulares 61

Figura 3.7 -Fotomicrografia da porção leucossômica 62

Figura 3.8 - Fotomicrografia de cristais de feldspato plagioclásio 62

Figura 3.9 - Granito Cinza Castelo 63

Figura 3.10 - Fotomicrografia de textura fanerítica média a média/fina 65

Figura 3.11 - Fotomicrografia de cristais de feldspato plagioclásio 65

Figura 3.12 - Migmatito Desert Storm 66

Figura 3.13 - Charnoquito Verde Labrador 71

Figura 3.14 - Fotomicrografia de megacristal de feldspato potássico 73

Figura 3.15 - Fotomicrografia de microfissuramento, intragranular e intergranular 73

Figura 3.16 - Granito Vermelho Capão Bonito 74

Figura 3.17 - Fotomicrografia mostrando saussuritização dos cristais de plagioclásio 77

Figura 3.18 - Seqüência metodológica utilizada nesta pesquisa 80 
Figura 3.19 - Equipamento utilizado para a medição da rugosidade superficial 81

Figura 3.20 - Procedimento da determinação da rugosidade das amostras de rocha 81

Figura 3.21 - Conjunto lupa digital e imagem captada para análise qualitativa 81

Figura 3.22 - Captação da imagem da superfície da amostra de rocha 81

Figura 4.1 - Medição da rugosidade superficial dos materiais subm. ao polimento 83

Figura 4.2 - Tipos de superfícies possíveis de visualização nos perfis de rugosidade 83

Figura 4.3 - Rugosidade do “granito” Preto Indiano na $1^{\text {a }}$ etapa de desgaste 84

Figura 4.4 - “Granito” Preto Indiano subm. a desgaste com abrasivo 24 mês 85

Figura 4.5 - Rugosidade do granito Vermelho Brasília na $1^{\text {a }}$ etapa de desgaste 86

Figura 4.6 - Granito Vermelho Brasília subm. a desgaste com abrasivo 24 mesh 86

Figura 4.7 - Rugosidade do granito Cinza Castelo na $1^{\text {a }}$ etapa de desgaste 87

Figura 4.8 - Granito Cinza Castelo subm. a desgaste com abrasivo 24 mesh 87

Figura 4.9 - Rugosidade do “granito” Desert Storm na 1ª etapa de desgaste 88

Figura 4.10 - “Granito” Desert Storm subm. a desgaste com abrasivo 24 mesh 88

Figura 4.11 - Rugosidade do “granito” Verde Labrador na $1^{\mathrm{a}}$ etapa de desgaste 89

Figura 4.12 - “Granito” Verde Labrador subm. a desgaste com abrasivo 24 mesh 89

Figura 4.13 - Rugosidade do granito Vermelho Capão Bonito na $1^{\mathrm{a}}$ etapa de desgaste 90

Figura 4.14 - Granito Vermelho Capão Bonito subm. a desgaste com abrasivo 24 mesh 90

Figura 4.15 - Rugosidade do “granito” Preto Indiano na 2a etapa de desgaste 91

Figura 4.16 - “Granito” Preto Indiano subm. a desgaste com abrasivo 36 mesh 91

Figura 4.17 - Rugosidade do granito Vermelho Brasília na $2^{a}$ etapa de desgaste 92

Figura 4.18 - Granito Vermelho Brasília subm. a desgaste com abrasivo 36 mesh 92

Figura 4.19 - Rugosidade do granito Cinza Castelo na $2^{\mathrm{a}}$ etapa de desgaste 93

Figura 4.20 - Granito Cinza Castelo subm. a desgaste com abrasivo 36 mesh 93

Figura 4.21 - Rugosidade do “granito” Desert Storm na 2a etapa de desgaste 94 
Figura 4.22 - “Granito” Desert Storm subm. a desgaste com abrasivo 36 mesh 94

Figura 4.23 - Rugosidade do “granito” Verde Labrador na 2a etapa de desgaste 95

Figura 4.24 - “Granito” Verde Labrador subm. a desgaste com abrasivo 36 mesh 95

Figura 4.25 - Rugosidade do granito Vermelho Capão Bonito na $2^{\mathrm{a}}$ etapa de desgaste 96

Figura 4.26 - Granito Vermelho Capão Bonito subm. a desgaste com abrasivo 36 mesh 96

Figura 4.27 - Rugosidade do “granito” Preto Indiano na 3 $3^{\text {a }}$ etapa de desgaste 97

Figura 4.28 - “Granito” Preto Indiano subm. a desgaste com abrasivo 60 mesh 97

Figura 4.29 - Rugosidade do granito Vermelho Brasília na $3^{\mathrm{a}}$ etapa de desgaste 98

Figura 4.30 - Granito Vermelho Brasília subm. a desgaste com abrasivo 60 mesh 98

Figura 4.31 - Rugosidade do granito Cinza Castelo na $3^{\mathrm{a}}$ etapa de desgaste 99

Figura 4.32 - Granito Cinza Castelo subm. a desgaste com abrasivo 60 mesh 99

Figura 4.33 - Rugosidade do “granito” Desert Storm na 3ª etapa de desgaste 100

Figura 4.34 - “Granito” Desert Storm subm. a desgaste com abrasivo 60 mesh 100

Figura 4.35 - Rugosidade do “granito” Verde Labrador na $3^{\text {a }}$ etapa de desgaste 101

Figura 4.36 - “Granito” Verde Labrador subm. a desgaste com abrasivo 60 mesh 101

Figura 4.37 - Rugosidade do granito Vermelho Capão Bonito na $3^{\text {a }}$ etapa de desgaste 102

Figura 4.38 - Granito Vermelho Capão Bonito subm. a desgaste com abrasivo 60 mesh 102

Figura 4.39 - Rugosidade do “granito” Preto Indiano na 4ª etapa de desgaste 104

Figura 4.40 - “Granito” Preto Indiano subm. a desgaste com abrasivo 120 mesh 104

Figura 4.41 - Rugosidade do granito Vermelho Brasília na $4^{\mathrm{a}}$ etapa de desgaste 105

Figura 4.42 - Granito Vermelho Brasília subm. a desgaste com abrasivo 120 mesh 105

Figura 4.43 - Rugosidade do granito Cinza Castelo na $4^{\mathrm{a}}$ etapa de desgaste 106

Figura 4.44 - Granito Cinza Castelo subm. a desgaste com abrasivo 120 mesh 106

Figura 4.45 - Rugosidade do “granito” Desert Storm na 4 a etapa de desgaste 107

Figura 4.46 - “Granito” Desert Storm subm. a desgaste com abrasivo 120 mesh 107 
Figura 4.47 - Rugosidade do “granito” Verde Lavrador na 4a etapa de desgaste 108

Figura 4.48 - “Granito” Verde Labrador subm. a desgaste com abrasivo 120 mesh 108

Figura 4.49 - Rugosidade do granito Vermelho Capão Bonito na $4^{\mathrm{a}}$ etapa de desgaste 109

Figura 4.50 - Granito Vermelho Capão Bonito subm. a desg. com abrasivo 120 mesh 109

Figura 4.51 - Rugosidade do “granito” Preto Indiano na 5ª etapa de desgaste 110

Figura 4.52 - “Granito” Preto Indiano subm. a desgaste com abrasivo 220 mesh 110

Figura 4.53 - Rugosidade do granito Vermelho Brasília na 5a etapa de desgaste 111

Figura 4.54 - Granito Vermelho Brasília subm. a desgaste com abrasivo 220 mesh 111

Figura 4.55 - Rugosidade do granito Vermelho Brasília na 5a etapa de desgaste 112

Figura 4.56 - Granito Cinza Castelo subm. a desgaste com abrasivo 220 mesh 112

Figura 4.57 - Rugosidade do “granito” Desert Storm na 5a etapa de desgaste 113

Figura 4.58 - “Granito” Desert Storm subm. a desgaste com abrasivo 220 mesh 113

Figura 4.59 - Rugosidade do “granito” Verde Labrador na 5ª etapa de desgaste 114

Figura 4.60 - “Granito” Verde Labrador subm. a desgaste com abrasivo 220 mesh 114

Figura 4.61 - Rugosidade do granito Vermelho Capão Bonito na 5a etapa de desgaste 115

Figura 4.62 - Granito Vermelho Capão Bonito subm. a desg. com abrasivo 220 mesh 115

Figura 4.63 - Rugosidade do “granito” Preto Indiano na 6a etapa de desgaste 116

Figura 4.64 - “Granito” Preto Indiano subm. a desgaste com abrasivo 400 mesh 116

Figura 4.65 - Intercalação composicional presente no “granito” Preto Indiano 117

Figura 4.66 - Rugosidade do granito Vermelho Brasília na 6a etapa de desgaste 117

Figura 4.67 - Granito Vermelho Brasília subm. a desgaste com abrasivo 400 mesh 118

Figura 4.68 - Rugosidade do granito Cinza Castelo na $6^{\text {a }}$ etapa de desgaste 118

Figura 4.69 - Granito Cinza Castelo subm. a desgaste com abrasivo 400 mesh 119

Figura 4.70 - Rugosidade do “granito” Desert Storm na 6a etapa de desgaste 119

Figura 4.71 - “Granito” Desert Storm subm. a desgaste com abrasivo 400 mesh 120 
Figura 4.72 - Rugosidade do "granito” Verde Labrador na 6a etapa de desgaste 120

Figura 4.73 - “Granito” Verde Labrador subm. a desgaste com abrasivo 400 mesh 121

Figura 4.74 - Rugosidade do granito Vermelho Capão Bonito na $6^{\text {a }}$ etapa de desgaste 121

Figura 4.75 - Granito Vermelho Capão Bonito subm. a desg. com abrasivo 400 mesh 122

Figura 4.76 - Rugosidade do “granito” Preto Indiano na 7 a etapa de desgaste 122

Figura 4.77 - “Granito” Preto Indiano subm. a desgaste com abrasivo 600 mesh 123

Figura 4.78 - Rugosidade do granito Vermelho Brasília na $7^{a}$ etapa de desgaste 124

Figura 4.79 - Granito Vermelho Brasília subm. a desgaste com abrasivo 600 mesh 124

Figura 4.80 - Rugosidade do granito Cinza Castelo na $7^{\text {a }}$ etapa de desgaste 125

Figura 4.81 - Granito Cinza Castelo subm. a desgaste com abrasivo 600 mesh 125

Figura 4.82 - Rugosidade do “granito” Desert Storm na 7a etapa de desgaste 126

Figura 4.83 - “Granito” Desert Storm subm. a desgaste com abrasivo 600 mesh 126

Figura 4.84 - Rugosidade do “granito” Verde Labrador na 7ª etapa de desgaste 127

Figura 4.85 - “Granito” Verde Labrador subm. a desgaste com abrasivo 600 mesh 127

Figura 4.86 - Rugosidade do granito Vermelho Capão Bonito na $7^{\mathrm{a}}$ etapa de desgaste 128

Figura 4.87 - Granito Vermelho Capão Bonito subm. a desg. com abrasivo 600 mesh 128

Figura 4.88 - Rugosidade do “granito” Preto Indiano na 8a etapa de desgaste 129

Figura 4.89 - Superfície com baixa rugosidade verificada na $8^{a}$ etapa de desgaste no "granito” Preto Indiano 129

Figura 4.90 - Rugosidade do granito Vermelho Brasília na 8a etapa de desgaste 130

Figura 4.91 - Granito Vermelho Brasília subm. a desgaste com abrasivo 800 mesh 130

Figura 4.92 - Rugosidade do granito Cinza Castelo na $8^{\text {a }}$ etapa de desgaste 131

Figura 4.93 - Granito Cinza Castelo subm. a desgaste com abrasivo 800 mesh 131

Figura 4.94 - Rugosidade do “granito” Desert Storm na 8a etapa de desgaste 132

Figura 4.95 - “Granito” Desert Storm subm. a desgaste com abrasivo 800 mesh 132 
Figura 4.96 - Rugosidade do "granito” Verde Labrador na $8^{\text {a }}$ etapa de desgaste 133

Figura 4.97 - “Granito” Verde Labrador subm. a desgaste com abrasivo 800 mesh 133

Figura 4.98 - Rugosidade do granito Vermelho Capão Bonito na $8^{\mathrm{a}}$ etapa de desgaste 134

Figura 4.99 - Granito Vermelho Capão Bonito subm. a desg. com abrasivo 800 mesh 134

Figura 4.100 - Rugosidade do “granito” Preto Indiano na 9a etapa de desgaste 135

Figura 4.101 - Superfície com baixa rugosidade verificada na $9^{a}$ etapa de desgaste 135

Figura 4.102 - Rugosidade do granito Vermelho Brasília na 9a etapa de desgaste 136

Figura 4.103 - Granito Vermelho Brasília subm. a desgaste com abrasivo 1200 mesh 136

Figura 4.104 - Rugosidade do granito Cinza Castelo na 9a etapa de desgaste 137

Figura 4.105 - Granito Cinza Castelo subm. a desgaste com abrasivo 1200 mesh 137

Figura 4.106 - Rugosidade do “granito” Desert Storm na 9a etapa de desgaste 138

Figura 4.107 - “Granito” Desert Storm subm. a desgaste com abrasivo 1200 mesh 138

Figura 4.108 - Rugosidade do “granito” Verde Labrador na 9a etapa de desgaste 139

Figura 4.109 - “Granito” Verde Labrador sub. a desgaste com abrasivo 1200 mesh 139

Figura 4.110 - Rugosidade do granito Vermelho Capão Bonito na 9a etapa de desgaste 140

Figura 4.111 - Granito Vermelho Capão Bonito subm. a desg. com abrasivo 1200 mesh 140

Figura 4.112 - Rugosidade do “granito” Preto Indiano na 10a etapa de desgaste 141

Figura 4.113 - “Granito” Preto Indiano na 10a etapa de desgaste 142

Figura 4.114 - Rugosidade do granito Vermelho Brasília na 10ª etapa de desgaste 142

Figura 4.115 - Granito Vermelho Brasília subm. a desgaste com abrasivo de lustro, mostrando alguns trincamentos de borda e no interior dos minerais 143

Figura 4.116 - Granito Vermelho Brasília subm. ao lustro com alguns cristais riscados 143

Figura 4.117 - Rugosidade do granito Cinza Castelo na 10ª etapa de desgaste 144

Figura 4.118 - Granito Cinza Castelo subm. a desgaste com abrasivo de lustro 144

Figura 4.119 - Rugosidade do “granito” Desert Storm na 10ª etapa de desgaste 145 
Figura 4.120 - “Granito” Desert Storm subm. a desgaste com abrasivo de lustro 145

Figura 4.121 - Rugosidade do “granito” Verde Labrador na 10ª etapa de desgaste 146

Figura 4.122 - “Granito” Verde Labrador submetido ao lustro com alguns cristais riscados pelo abrasivo e microfissuras intragrão e intergrão 146

Figura 4.123 - Rugosidade do granito Vermelho Capão Bonito na $10^{\mathrm{a}}$ etapa de desgaste 147

Figura 4.124 - Granito Vermelho Capão Bonito submetido a solicitações de desgaste com abrasivo de lustro 147

Figura 4.125 - Disposição dos pontos de leitura do brilho nos corpos-de-prova 148

Figura 4.126 - Exemplo dos corpos-de-prova utilizados para a medição do brilho 148

Figura 4.127 - Procedimento de medida do brilho nas amostras estudadas 148

Figura 4.128 - Comparação entre os resultados de brilho 155

Figura 4.129 - Seção transv. de um sulco de desgaste produz. por uma part. abrasiva 158

Figura 4.130 - Esquema do ensaio de abrasão com o equipamento pin-on-disk 160

Figura 4.131 - Principais componentes do equipamento utilizado para a realização do ensaio de pin-on-disk tradicional 160

Figura 4.132 - Politriz para preparação de lâmina delgada para rochas utilizada como base para o desenvolvimento do SPR 161

Figura 4.133 Conjunto de dispositivos acoplados a politriz para a montagem SPR 162

Figura 4.134 - Equipamento para ensaio de simulação de polimento em rocha (SPR 162

Figura 4.135 - Detalhe do ensaio de SPR 163

Figura 4.136 - Amostragem do corpo-de-prova de rocha utilizado no ensaio SPR 163

Figura 4.137 - Retificação da geratriz do corpo-de-prova para o ensaio SPR 164

Figura 4.138 - Amostragem do corpo-de-prova de abrasivo utilizado no ensaio SPR 164

Figura 4.139 - Amostra retirada do rebolo abrasivo para o ensaio SPR 164

Figura 4.140 - Esquema do corpo-de-prova de rocha utilizado no ensaio SPR 165 
Figura 4.141 - Corpo-de-prova submetido ao ensaio SPR 166

Figura 4.142 - Modelo de planilha utilizado no SPR 168

Figura 4.143 - Perda de massa de rocha na $1^{\text {a }}$ fase de desgaste (24 mesh) 171

Figura 4.144 - Perda de massa de rocha na $2^{\mathrm{a}}$ fase de desgaste (36 mesh) 171

Figura 4.145 - Perda de massa de na $3^{\text {a }}$ fase de desgaste (60 mesh) 172

Figura 4.146 - Perda de massa de na $4^{\text {a }}$ fase de desgaste (120 mesh) 173

Figura 4.147 - Gráficos de superfície mostrando a intensidade do desgaste do "granito” Preto Indiano ao longo de diferentes condições de desgaste com os abrasivos de granulometrias 24, 36, 60 e 120 mesh 175

Figura 4.148 - Gráficos de superfície mostrando a intensidade do desgaste do granito Vermelho Brasília ao longo das diferentes condições de desgaste com os abrasivos de granulometrias 24, 36, 60 e 120 mesh 175

Figura 4.149 - Gráficos de superfície mostrando a intensidade do desgaste do granito Cinza Castelo ao longo das diferentes condições de desgaste com os abrasivos de granulometrias 24, 36, 60 e 120 mesh 176

Figura 4.150 - Gráficos de superfície mostrando a intensidade do desgaste do "granito" Desert Storm ao longo das diferentes condições de desgaste com os abrasivos de granulometrias 24, 36, 60 e 120 mesh 177

Figura 4.151 - Gráficos de superfície mostrando a intensidade do desgaste do “granito” Verde Labrador ao longo das diferentes condições de desgaste com os abrasivos de granulometrias 24, 36, 60 e 120 mesh 177

Figura 4.152 - Gráficos de superfície mostrando a intensidade do desgaste do granito Vermelho Capão Bonito ao longo das diferentes condições de desgaste com os abrasivos de granulometrias 24, 36, 60 e 120 mesh 178 
Figura 4.153 - Gráfico em linha mostrando taxas de desgaste dos abrasivos no "granito” Preto Indiano ao longo das etapas de desgaste com as granulometrias de abrasivo 24, 36, 60 e 120 mesh 179

Figura 4.154 - Gráfico em linha mostrando taxas de desgaste dos abrasivos no granito Vermelho Brasília ao longo das etapas de desgaste com as granulometrias de abrasivo 24, 36, 60 e 120 mesh 180

Figura 4.155 - Gráfico em linha mostrando taxas de desgaste dos abrasivos no granito Cinza Castelo ao longo das etapas de desgaste com as granulometrias de abrasivo 24, 36, 60 e 120 mesh 180

Figura 4.156 - Gráfico em linha mostrando taxas de desgaste dos abrasivos no "granito" Desert Storm ao longo das etapas de desgaste com as granulometrias de abrasivo 24, 36, 60 e 120 mesh 181

Figura 4.157 - Gráfico em linha mostrando taxas de desgaste dos abrasivos no "granito" Verde Labrador ao longo das etapas de desgaste com as granulometrias de abrasivo 24, 36, 60 e 120 mesh 182

Figura 4.158 - Gráfico em linha mostrando taxas de desgaste dos abrasivos no granito Vermelho Capão Bonito ao longo das etapas de desgaste com as granulometrias de abrasivo 24, 36, 60 e 120 mesh 182

Figura 4.159 - Perda de massa de abrasivo na $5^{\text {a }}$ fase de desgaste (220 mesh) 183

Figura 4.160 - Perda de massa de abrasivo na $6^{a}$ fase de desgaste (400 mesh) 184

Figura 4.161 - Perda de massa de abrasivo na $7^{\text {a }}$ fase de desgaste (600 mesh) 185

Figura 4.162 - Perda de massa de abrasivo na $8^{\text {a }}$ fase de desgaste (800 mesh) 186

Figura 4.163 - Perda de massa de abrasivo na $9^{\text {a }}$ fase de desgaste (1200 mesh) 187

Figura 4.164 - Perda de massa de abrasivo na $10^{\text {a }}$ fase de desgaste (lustro) 188

Figura 4.165 - Conjunto de todos os corpos-de-prova SPR 192 
Figura 4.166 - Detalhe do corpo-de-prova após ensaio no SPR 192

Figura 4.167 - Curva de freq. acumulada de brilho para o “granito” Preto Indiano 193

Figura 4.168 - Curva de freq. acumulada de brilho para o granito Vermelho Brasília 194

Figura 4.169 - Curva de freq. acumulada de brilho para o granito Cinza Castelo 194

Figura 4.170 - Curva de freq. acumulada de brilho para o “granito” Verde Labrador 195

Figura 4.171 - Curva de freq. acumulada de brilho para o “granito” Desert Storm 196

Figura 4.172 - Curva de freq. acum. de brilho para o granito Vermelho Capão Bonito 196 


\section{LISTA DE TABELAS}

TABELA 2.1 - Índice de refração para alguns materiais não metálicos 07

TABELA 4.1 - Valores de brilho nas amostras do granito Vermelho Brasília 149

TABELA 4.2 - Valores de brilho nas amostras do “granito” Preto Indiano 150

TABELA 4.3 - Valores de brilho nas amostras do granito Cinza Castelo 151

TABELA 4.4 - Valores de brilho nas amostras do "granito” Desert Storm 152

TABELA 4.5 - Valores de brilho nas amostras do “granito” Verde Labrador 153

TABELA 4.6 - Valores de brilho nas amostras do granito Vermelho Capão Bonito 154

TABELA 4.7 - Nomenclatura das amostras utilizadas no SPR 167 


\section{LISTA DE QUADROS}

QUADRO 2.1 - Estágios de polimento utilizados por Erdogan (2000) 14 


\section{RESUMO}

Este trabalho apresenta uma contribuição experimental cujo objetivo é fornecer elementos para o aprimoramento tecnológico das etapas de polimento de rochas ornamentais. Alguns aspectos da Tribologia, ramo do conhecimento amplamente utilizado nas Engenharias Mecânica e de Materiais, foram transferidos para o estudo do polimento de rochas ornamentais e subsidiaram a investigação da interação do tribossistema composto pela rocha, pelo abrasivo e por condições operacionais. Foi desenvolvido um equipamento em laboratório que possibilitou a simulação do processo de polimento, em diversas condições operacionais, considerando as variáveis tempo, velocidade de rotação e intensidade das cargas aplicadas. Foram comparados polimentos, em condições industrial e laboratorial de rochas graníticas, visando estabelecer as influências das suas características composicionais, texturais e estruturais no processo. Os resultados permitiram definir as condições ideais para a obtenção de melhor qualidade no brilho das rochas e representa uma contribuição tanto para o entendimento do processo de polimento propriamente dito como também para a otimização do processo industrial.

Palavras-chave: polimento, granitos, rugosidade, brilho 


\begin{abstract}
This work shows an experimental contribution which goal is to provide elements to the technological improvement of each step of dimension stones polishing. Some aspects of Tribology, a discipline of Mechanical and Material Engineering, has been used on the research of dimension stones polishing and has supported the investigation of the interaction of the tribosystem composed of rock, abrasive and operational conditions. For this research, a device was developed in the lab in order to make possible the simulation of the polishing process at different operational conditions, considering the variables time, rotation speed, and intensity of the loads applied. The polishing of granite rocks at industrial and lab conditions has been compared, aiming at determining the influence of each rock characteristics such as mineral composition, texture and structure during the process. The results allowed for the definition of the ideal conditions to obtain the best quality of rock brightness and they represent a contribution to the understanding of the polishing process itself as well as provide an optimization of the industrial process.
\end{abstract}

Key words: polishing, granites, rugosity, brightness 


\section{INTRODUÇÃO}

\subsection{PANORAMA GERAL DO SETOR}

O Brasil detém uma posição privilegiada na produção mundial de matérias-primas de origem mineral, principalmente em relação ao nióbio ( $\left.1^{\text {a }} ; 91,4 \%\right)$, podendo destacar também o ferro $\left(2^{\mathrm{a}} ; 20,8 \%\right)$, tântalo $\left(2^{\mathrm{a}} ; 20,1 \%\right)$, alumínio $\left(2^{\mathrm{a}} ; 13 \%\right)$, manganês $\left(3^{\mathrm{a}} ; 11,8 \%\right)$, grafita natural $\left(3^{\mathrm{a}} ; 10,1 \%\right)$, magnesita $\left(3^{\mathrm{a}} ; 9,6 \%\right)$, crisotila/amianto $\left(4^{\mathrm{a}} ; 11,1 \%\right)$, rochas ornamentais $\left(4^{\mathrm{a}} ; 8,2 \%\right)$, vermiculita $\left(4^{\mathrm{a}} ; 6,8 \%\right)$, caulim $\left(5^{\mathrm{a}} ; 5,4 \%\right)$ e estanho $(5 ; 5 \%)(\mathrm{DNPM}, 2006)$.

A indústria de rochas ornamentais no Brasil tem sido um dos poucos setores da economia que apresentou, ao longo dos anos 90, um crescimento nas taxas médias anuais de evolução da produção. Segundo dados do DNPM, a produção de rochas ornamentais no mundo, na década de 90, foi de 40 milhões t/ano e no início desta década foram atingidos os 50 milhões t/ano, gerando cerca de US\$ 9 bilhões no comércio de rochas em estado bruto, ou US\$ 25 bilhões referente à rocha beneficiada. A previsão para 2005 era alcançar uma produção mundial de 75 milhões de toneladas de rocha bruta, o que daria um acúmulo de divisas na ordem de US\$ 14 bilhões (FIRJAN, 1999).

Os países desenvolvidos que atuam de forma marcante na indústria de rochas ornamentais (Itália, França, Espanha, entre outros), além de terem tradição no setor, apresentam o domínio das técnicas de extração, beneficiamento e produção de equipamentos.

Especificamente no setor de rochas ornamentais, o Brasil, apesar de ter apresentado uma significativa melhora na qualidade operacional de seus parques industriais, principalmente se referindo às técnicas de beneficiamento primário (desdobramento) e secundário (polimento), ainda não tem atentado para a importância de desenvolver, de uma forma mais intensa, pesquisas nesse importante setor produtivo. 
Entre os motivos pelos quais não há uma maior incorporação tecnológica no setor de rochas ornamentais, Villaschi e Sabadini (1999) destacam: a falta de uma política pública para o setor, a baixa capacidade das empresas em investir em pesquisa e desenvolvimento, a dificuldade em mobilizar recursos e o período recessivo vivido pela economia brasileira nas últimas décadas.

Apesar do movimento de abertura comercial ter proporcionado uma maior absorção de máquinas e equipamentos com maior grau tecnológico, o que não significa dizer desenvolvimento local de inovação, a escala de produção das empresas brasileiras é menor do que as estrangeiras que produzem pesquisas e investem em novas tecnologias.

Em todo o processo de beneficiamento de rocha ornamental, existem lacunas no conhecimento que, em última análise, geram custos, contribuindo para uma inviabilidade da indústria nacional em competir com o seu produto, acabado ou semi-acabado, no mercado internacional.

Uma das etapas carente de pesquisa e que só tem sido tratada empiricamente é a referente ao processo do polimento de placas de rocha. A compreensão do polimento como sendo um processo de desgaste de uma superfície em que existe uma íntima relação entre as muitas variáveis envolvidas ainda não é completa. As características intrínsecas da rocha, os tipos de politriz, os tipos e formas de abrasivos são alguns dos fatores que influem no produto final e que ficam, quase sempre, colocados em segundo plano. O modo de abordagem deste processo, em muitos casos, se aproxima muito do enfoque adotado pela "tribologia", ramo da engenharia mecânica que estuda os mecanismos de desgaste em ligas metálicas. É nesse sentido que um trabalho desta natureza proporcionará uma contribuição efetiva no conhecimento dos mecanismos de desgaste existentes em um material natural (rocha) quando submetidos ao polimento. 


\subsection{OBJETIVO}

Este trabalho tem como objetivo entender o processo de polimento de rochas ornamentais a partir de uma abordagem abrangente, na medida em que considera as características do material rochoso como um dos principais elementos responsáveis pela qualidade final do polimento. Visa também identificar quais mecanismos que influem na qualidade do produto final e no consumo dos abrasivos. Pretende ainda gerar conhecimentos que possibilitem condições operacionais ideais, que levem em consideração os fatores intrínsecos do processo e as propriedades tecnológicas da rocha. 


\section{REVISÃO BIBLIOGRÁFICA}

\subsection{BRILHO}

A função da etapa de polimento de rochas ornamentais tem como função conferir brilho, além de dar um fechamento maior dos poros e com isso evitar infiltração de água, evitando assim a alteração da rocha por hidrólise. Serão apresentados a seguir alguns aspectos relacionados ao brilho.

\subsubsection{PROPRIEDADE ÓPTICA}

Entende-se por propriedade óptica a resposta que um material apresenta quando exposto à radiação eletromagnética e, em particular, à luz visível. No sentido clássico, a radiação eletromagnética é caracterizada como sendo ondulatória, consistindo em componentes de campo elétrico e de campo magnético, os quais são perpendiculares um ao outro e também à direção de propagação. O espectro eletromagnético da radiação abrange uma larga faixa que vai desde os raios $\gamma$ (emitidos pro materiais radioativos), com comprimentos de onda da ordem de $10^{-12} \mathrm{~m}\left(10^{-3} \mathrm{~nm}\right)$, e passa pelos raios $x$, ultravioleta, visível, infravermelho e, finalmente, as ondas de rádio, com comprimentos da ordem de $10^{5} \mathrm{~m}$. A luz visível está localizada dentro de uma região muito estreita do espectro, com comprimentos de onda que variam entre $0,4 \mu \mathrm{m}$ e $0,7 \mu \mathrm{m}$.

\subsubsection{INTERAÇÕES DA LUZ COM SÓLIDOS}

Quando a luz passa de um meio para outro, parte da radiação luminosa pode ser transmitida através do meio, uma parte será absorvida e uma parte será refletida na interface entre os dois meios. A intensidade $\left(I_{0}\right)$ do feixe incidente sobre a superfície do meio sólido 
deve ser igual a soma das intensidades dos feixes transmitido, absorvido e refletido $\left(\mathrm{I}_{t}, \mathrm{I}_{\mathrm{a}}, \mathrm{I}_{\mathrm{r}}\right.$, respectivamente), ou seja:

$$
I_{0}=I_{t}+I_{a}+I_{r}
$$

Os materiais capazes de transmitir a luz com absorção e reflexão relativamente pequenas são chamados de transparentes. Os materiais chamados translúcidos são aqueles através dos quais a luz é transmitida de modo difuso, isto é, a luz é dispersa no interior do material num grau em que os objetos não são claramente distinguíveis quando observados através de uma amostra desse material. Aqueles materiais que são impenetráveis à transmissão da luz visível são conhecidos por opacos (CALLISTER, 2000). A Figura 2.1 mostra um exemplo de diferentes graus de transmitância da luz através de um sólido.

Em mineralogia, a propriedade óptica que distingue estes três principais tipos de material é chamada de diafaneidade. Logo, a diafaneidade, considerando todos os minerais que compõem uma amostra de rocha polida, tem muita importância na sua capacidade de refletir a luz, o que, em última análise, influenciará o brilho da placa.

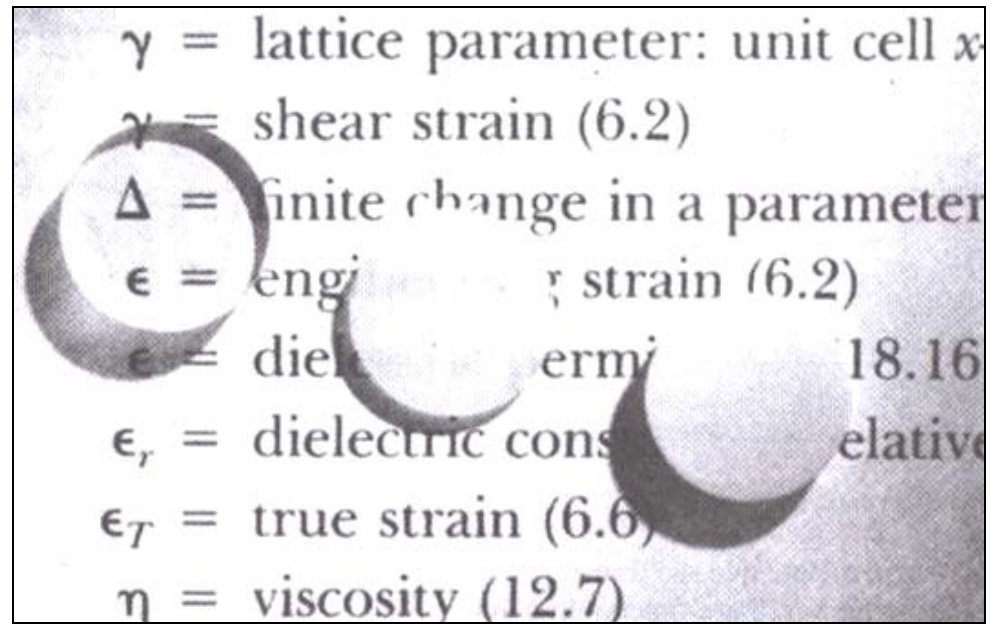

Figura 2.1 - Fotografia mostrando a transmitância da luz exibida por três amostras de óxido de alumínio (CALLISTER, 2000). 


\subsubsection{PROPRIEDADES ÓPTICAS DE MINERAIS NÃO-METÁLICOS}

Ao contrário dos minerais metálicos, os não-metálicos (que representam a maioria absoluta dos minerais formadores das rochas para fins ornamentais) podem ser transparentes à luz visível. Portanto, além da reflexão, os fenômenos da refração e da transmissão precisam ser considerados.

\section{REFRAÇÃO}

Este fenômeno ocorre quando a luz que é transmitida para o interior de minerais nãometálicos experimenta uma diminuição da velocidade e, como resultado, muda o ângulo de incidência na interface do material. O índice de refração de determinado material $(n)$ pode ser definido como sendo a razão entre a velocidade da luz no vácuo (c) e a velocidade da luz no meio ( $v)$, ou seja:

$$
n=\frac{c}{v}
$$

Por sua vez, a velocidade da luz em um referido meio sólido não-metálico pode ser obtida através da equação:

$$
v=\frac{1}{\sqrt{\varepsilon \cdot \mu}} \text { onde: }
$$

$\varepsilon$ - permissividade elétrica do meio;

$\mu$ - permeabilidade magnética do meio.

A equação que mostra a velocidade da luz no vácuo é a seguinte:

$$
c=\frac{1}{\sqrt{\varepsilon_{0} \cdot \mu_{0}}}
$$

A partir desta equação temos: 


$$
n=\frac{c}{v}=\frac{\sqrt{\varepsilon \cdot \mu}}{\varepsilon_{0} \cdot \mu_{0}}=\sqrt{\varepsilon_{r} \cdot \mu_{r}}
$$

Uma vez que a maioria dos minerais não-metálicos é apenas ligeiramente magnética, $\mu \cong 1, \mathrm{e}:$

$$
n \cong \sqrt{\varepsilon_{r}}
$$

Na Tabela 2.1 é mostrada uma relação dos valores de índice de refração para alguns materiais não metálicos.

TABELA 2.1 - Índice de refração para alguns materiais não metálicos (CALLISTER, 2000).

\begin{tabular}{|l|c|}
\hline \multicolumn{1}{|c|}{ MATERIAL } & ÍNDICE DE REFRAÇÃO MÉDIO $(n)$ \\
\hline Vidro de sílica & 1,458 \\
\hline Vidro borossilicato (Pyrex) & 1,47 \\
\hline Vidro de cal de soda & 1,51 \\
\hline Quartzo & 1,55 \\
\hline Vidro óptico de sílex denso & 1,65 \\
\hline Espinélio & 1,72 \\
\hline Periclásio & 1,74 \\
\hline Córindon & 1,76 \\
\hline
\end{tabular}

\section{REFLEXÃO}

Quando a radiação luminosa passa de um meio para outro com índice de refração diferente, uma parte da luz é dispersa na interface entre os dois meios, mesmo se ambos os materiais forem transparentes. A refletividade (R) representa aquela fração da luz incidente que é refletida na interface, ou seja:

$$
R=\frac{I_{R}}{I_{0}} \quad \text { onde: }
$$


$I_{0}$ e $I_{R}$ são as intensidades dos feixes incidente e refletido, respectivamente.

Se a luz incidir em direção normal à interface, então:

$$
R=\left(\frac{n_{2}-n_{1}}{n_{2}+n_{1}}\right)^{2} \text { onde: }
$$

$\mathrm{n}_{1}$ e $\mathrm{n}_{2}$ são os índices de refração dos dois meios.

Se a luz incidente não incidir em direção normal à interface, o valor de $\mathrm{R}$ irá depender do ângulo de incidência. Quando a luz é transmitida do vácuo ou do ar para o interior de um sólido (s), uma vez que o índice de refração do ar é muito próximo a 1, tem-se:

$$
R=\left(\frac{n_{s}-1}{n_{s}+1}\right)^{2}
$$

É possível notar que, quanto maior for o índice de refração de um sólido, maior será a sua refletividade (CALLISTER, 2000).

\section{ABSORÇÃO}

Os materiais não-metálicos podem ser opacos ou transparentes à luz visível; e, no caso de serem transparentes, com freqüência exibem uma aparência colorida. Em princípio, a radiação luminosa é absorvida nesse grupo de materiais segundo dois mecanismos básicos, os quais também influenciam as características de transmissão desses materiais. Um desses mecanismos é a polarização eletrônica. A absorção por polarização eletrônica é importante apenas para freqüências da luz na vizinhança da freqüência de relaxação dos átomos constituintes. O outro mecanismo envolve transições eletrônicas da banda de valência para a banda de condução, as quais dependem da estrutura da banda de energia dos elétrons do material (CALLISTER, op. cit). 
A absorção de um fóton de luz pode ocorrer pela promoção ou excitação de um elétron de uma banda de valência praticamente preenchida, através do espaçamento entre bandas, para um estado vazio dentro da banda de condução; são criados um elétron livre na banda de condução e um buraco na banda de valência. Novamente, a energia de excitação $(\Delta E)$ está relacionada à freqüência do fóton absorvido. Tais excitações, com suas conseqüentes absorções de energia, podem ocorrer somente se a energia do fóton for maior que a energia do espaçamento entre banda $\left(E_{e}\right)$, isto é, se:

$$
h v>E_{e}
$$

ou, em termos de comprimento de onda:

$$
\frac{h c}{\lambda}>E_{e}
$$

De acordo com o exposto, nenhuma luz visível é absorvida por materiais nãometálicos que possuem energias do espaçamento entre bandas maiores do que aproximadamente 3,1 eV (eletrovolt); tais materiais, se forem de alta pureza, terão aparência transparente e incolor. Por outro lado, o comprimento de onda máximo para a luz visível ( $\lambda$ max) é de aproximadamente $0,7 \mu \mathrm{m}$, o cálculo da energia mínima do espaçamento entre bandas ( $\left.\mathrm{E}_{\mathrm{e}} \mathrm{min}\right)$, para a qual existe absorção da luz visível se dá conforme:

$$
\begin{gathered}
E_{e}(\min )=\frac{h c}{\lambda \max } \\
=\frac{\left(4,13 \times 10^{-15} \mathrm{eVs}\right) \cdot\left(3 \times 10^{8} \mathrm{~m} / \mathrm{s}\right)}{7 \times 10^{-7} \mathrm{~m}}=1,8 \mathrm{eV}
\end{gathered}
$$

Esse resultado significa que toda luz visível é absorvida por transições eletrônicas da banda de valência para a banda de condução naqueles materiais semicondutores que possuem energias do espaçamento entre bandas menores do que aproximadamente 1,8 eV; dessa forma, 
estes materiais são opacos. Apenas uma fração do espectro visível é absorvida pelos materiais que possuem energias do espaçamento entre bandas entre 1,8 e 3,1 eV, conseqüentemente, estes materiais podem apresentar uma aparência colorida (CALLISTER, 2000).

\section{TRANSMISSÃO}

Os fenômenos de absorção, reflexão e transmissão podem ser aplicados à passagem de luz através de um sólido transparente. Para um feixe incidente com intensidade $I_{0}$ que cai sobre uma superfície anterior de uma amostra com espessura $l$ e com um coeficiente de absorção $\beta$, a intensidade transmitida na face posterior, $I_{t}$, é de:

$$
I_{t}=I_{0}(1-R)^{2} e^{-\beta l} \quad \text { onde, }
$$

$\mathrm{R}$ representa a refletância; para esta expressão considera-se que o mesmo meio exista tanto fora da face anterior como fora da face posterior. Dessa forma, a fração da luz incidente que é transmitida através de uma material transparente depende das perdas que são incorridas pela absorção e reflexão.

\section{COR}

Os materiais transparentes têm uma aparência colorida como conseqüência da absorção seletiva de faixas específicas de comprimentos de ondas da luz. A cor observada é o resultado da combinação dos comprimentos de onda que são transmitidos. Se a absorção da luz é uniforme para todos os comprimentos de onda visíveis, o material tem uma aparência incolor; exemplos dessa situação são os vidros inorgânicos de alta pureza e os monocristais de alta pureza de diamantes e safiras. 


\subsubsection{A QUALIDADE DO BRILHO DE CHAPAS DE ROCHA POLIDA}

O processo de polimento e lustro de placas de rochas ornamentais se caracteriza por ser uma série de operações que reduzem a rugosidade da superfície trabalhada com vista a transformá-la em uma placa com determinada intensidade de brilho. A intensidade do brilho que determinada superfície apresenta é função das propriedades refletivas do material, sendo também inversamente proporcional à rugosidade da superfície. Logo, o brilho e o lustro de uma rocha ornamental são conseguidos pela eliminação destas rugosidades herdadas na etapa de beneficiamento primário e pelo "fechamento dos poros" entre os diferentes minerais que formam a rocha. Isto se dá pela ação de elementos abrasivos que, conduzidos em movimentos de atrito sobre o material, vão desbastando-o até atingir o grau de polimento desejado, através do uso de abrasivos com granulometria decrescente (KASCHNER, 1996).

Para Cayless e Marseden (1991) o brilho de uma superfície pode ser definido como sendo a razão entre a intensidade de luz incidente pela intensidade de luz refletida.

A qualidade final do polimento de uma placa de rocha ornamental é determinada apenas por métodos empíricos. Como regra geral, tal parâmetro é inferido pela granulometria dos abrasivos utilizados durante as etapas de levigamento e polimento. Porém, a escolha do tipo de abrasivo, a carga e velocidade de rotação das cabeças de polimento e a velocidade de avanço da placa também são variáveis que assumem uma grande importância no brilho da placa (BLASI et. al., 1995).

\subsubsection{FATORES QUE INFLUEM NO POLIMENTO DE ROCHAS}

\section{ORNAMENTAIS}

Certas características inerentes à rocha e outras relativas aos processos de beneficiamento são de fundamental importância para a melhor compreensão da etapa de polimento em rocha. Os principais fatores são detalhados a seguir: 


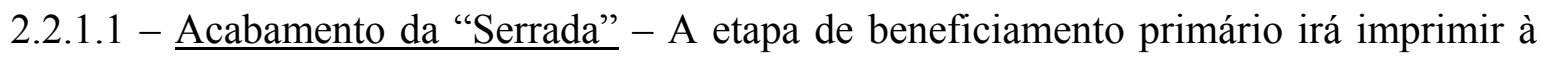
superfície da placa uma determinada rugosidade. Esta rugosidade será função da qualidade da serragem que o bloco de rocha sofreu. Quanto melhor for a qualidade da serrada menos rugosa será a superfície da chapa, e por conseqüência menor também o gasto de abrasivos nas primeiras etapas de polimento. De acordo com Cetemag (2003) para se definir se a serrada foi de boa qualidade, deve-se fazer as seguintes análises:

- Correr por toda a extensão da chapa, nas direções vertical, horizontal e diagonal, com o auxílio de uma régua de alumínio grande, para verificar se há empeno;

- Observar a presença de canaletas e entradas de lâminas nas cabeceiras de chapas, causadas por mal tensionamento de lâminas ou quebra de bico de lâminas inadequada.

2.2.1.2 Dureza da Rocha - Antes de começar o polimento, deve-se estabelecer a seqüência correta dos grãos abrasivos, em função do tipo de rocha que será polida, levando-se em conta a sua dureza e o grau de dificuldade de fechamento entre as fases minerais presentes. As rochas ornamentais são divididas em: duras, médias e macias. Os critérios para esta divisão são puramente empíricos. Faz-se seguindo características operacionais (tempo gasto na serrada, velocidade de polimento, etc.), não se tendo um real entendimento de quais características das rochas que podem influir neste processo (mineralogia, textura, estrutura, grau de alteração, etc.).

2.2.1.3 "Fechamento" do Polimento - A Indústria da Pedra convenciona chamar de fechamento uma característica relacionada com espaços e depressões que algumas placas já polidas podem apresentar. Tal fator está relacionado principalmente com a mineralogia: rochas sem quartzo, granada e biotita, (os sienitos, por exemplo) tendem a apresentar bom fechamento. Porém, não se deve esquecer da qualidade do processo a que a rocha foi submetida. Muitas vezes a pressão de carregamento nos satélites pode ter superado a resistência mecânica do mineral, levando-o assim ao quebramento e a abertura de poros. 
De acordo com Erdogan (2000), as variáveis que mais influem na capacidade de uma determinada superfície de rocha polida refletir a luz são:

- Irregularidades de superfície - tais feições podem refletir a luz incidente em diferentes ângulos gerando uma diminuição no brilho da superfície;

- Propriedades do material rochoso - mineralogia, massa específica e tamanho dos cristais, direção de corte em relação à orientação dos cristais e preenchimentos de macro e micro descontinuidades. O brilho de uma superfície de rocha polida também é função da diafaneidade dos cristais, visto que os mesmos, muitas vezes refratam a luz incidente diminuindo assim, a quantidade de luz refletida.

As propriedades da rocha são influenciadas pela composição mineralógica, textura (tamanho e forma), fabric (arranjo mineral e vazios) e grau de alteração. Especificamente em granitos, as variáveis que mais influem nas propriedades mecânicas são: tamanho e forma dos grãos, grau de imbricamento, tipo de contato e composição mineralógica (IRFAN,1996 apud TUGRUL e ZARIF, 1999).

Rochas constituídas essencialmente por apenas um mineral, por exemplo, mármores e calcários, mostram aumento nos valores de brilho com a diminuição da granulação, enquanto que rochas magmáticas com alto conteúdo em micas e com granulação grosseira têm uma diminuição nesta propriedade (ERDOGAN, op. cit.).

O mesmo autor conciliou tal procedimento com métodos de análise de imagens (Figura 2.2). Tal experimento consiste de um sistema que utiliza a luz refletida (d) à $60^{\circ} \mathrm{em}$ uma placa de rocha, sendo o brilho (luz refletida) captado por uma câmera de vídeo de alta resolução (c), que por sua vez é conectada a um conjunto computador (a) e impressora (b). O produto final é uma figura que expressa as diferenças de brilho ao longo da superfície na escala de tons de cinza, que foi chamado de mapa de isobrilho. 


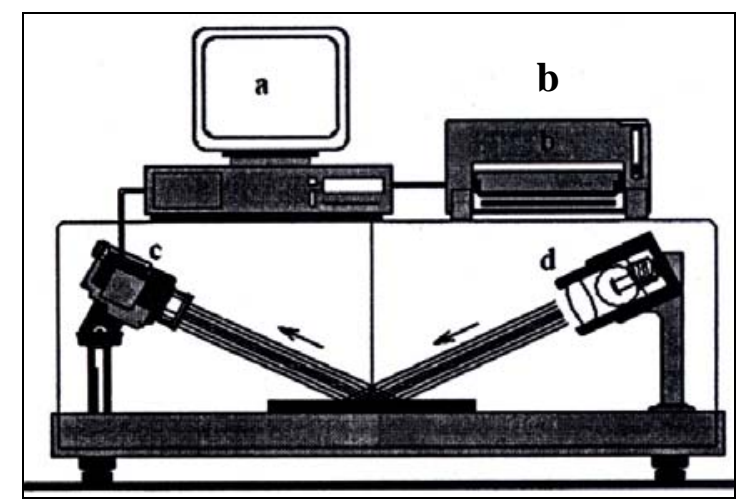

Figura 2.2 - Equipamento para medição do brilho de placas polidas (ERDOGAN, 2000).

A preparação de todas as amostras de duas rochas ornamentais foi feita em oito estágios de polimento (Quadro 2.1), sendo constatado que em ambos materiais estudados os valores do brilho são inversamente proporcionais à rugosidade da superfície (Figura 2.3).

QUADRO 2.1 - Estágios de polimento utilizados por Erdogan (200)
\begin{tabular}{|ccc}
\hline $\begin{array}{c}\text { Estágio de Tratamento } \\
\text { da Superflcie }\end{array}$ & Granulonnetrĩa do Abpasivo \\
\hline Levigamento & G1 & 180 \\
& G2 & 180,200 \\
& G3 & $180,200,220$ \\
& G4 & $180,200,220,280$ \\
& G5 & $180,200,220,280,360$ \\
& G6 & $180,200,220,280,360,400$ \\
& G7 & $180,200,220,280,360,400,600$ \\
& P & Polimento padpão \\
\hline
\end{tabular}

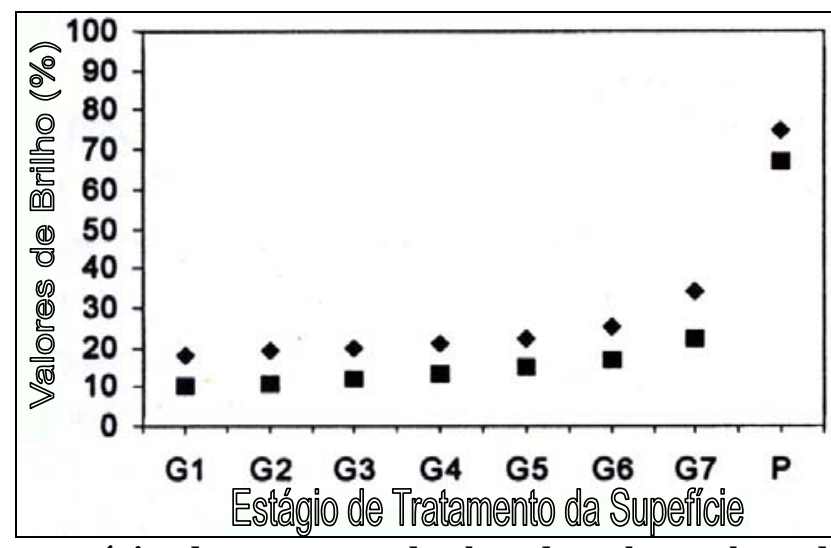

Figura 2.3 - Relação entre estágios de tratamento da placa de rocha e valores de brilho Erdogan (2000). Notar a relação diretamente proporcional entre estas variáveis. 
De acordo com o autor, as variáveis que mais influíram na qualidade do brilho foram:

1 - Micro e macro-poros - Uma certa quantidade da luz incidente na superfície da chapa é absorvida por micro e macro descontinuidades presentes na rocha. Limites entre os minerais juntamente com planos de clivagem e micro feições herdadas na gênese do material são as principais fontes de descontinuidades.

Simmons e Richter (1976, apud Kranz 1983) subdividem as micro-descontinuidades, chamadas por eles de microfissuras, em:

- Fissuras de borda de grão - Podem ser subdivididas em coincidentes ou não coincidentes ao limite atual do cristal. É normalmente difícil fazer a distinção entre estes dois tipos pelo fato de que a visualização do limite do grão muitas vezes não é óbvia. Em rochas que sofrem solicitação térmica ou mecânica as fissuras de borda de grãos podem se propagar e se tornarem contínuas ao longo de vários espaços intercristalinos.

- Fissuras intracristalinas - Se caracterizam por serem relativamente pequenas, geralmente muito menores do que o diâmetro do grão (em comprimento) e cerca de $1 \mu \mathrm{m}$ ou menos em espessura. Tais fissuras, quando naturais, podem estar preenchidas por outro material.

- Fissuras intercristalinas - Tais fissuras se caracterizam por serem maiores do que as fissuras intracristalinas, mas são morfologicamente similares. Em solicitação mecânica, as fissuras intercristalinas são normalmente orientadas subparalelamente à direção de maior tensão.

- Fissuras de clivagem - É um importante subitem das fissuras do tipo intracristalina e merece ser considerada separadamente. Elas são separações ao longo dos planos de clivagem de um mineral e ocorrem freqüentemente com vários comprimentos dentro de um determinado mineral. Vários planos de clivagem dentro do grão podem se fissurar. Em certas rochas, fissuras de clivagem podem estar preenchidas por materiais de alteração. 
Um dos desafios no tocante ao polimento de rochas ornamentais é saber se o processo de polimento, por si só, ajuda a criar novas fissuras ou interfere nas preexistentes, abrindo-as ou fechando-as. Tal constatação poderá mudar a forma de ver o material pétreo como apenas um coadjuvante do processo de beneficiamento. Todas as variáveis relacionadas à rocha, de certa forma, influem no seu comportamento quando submetidas ao polimento, mas não se sabe, exatamente, quais, nem o quanto.

A agressão que o material pétreo sofre, desde a lavra até o lustro é, na maioria dos casos não levada em consideração. As características de resistência mecânica dos diferentes constituintes minerais (ou fases minerais) são diferentes entre si. Logo, a melhor situação de beneficiamento da rocha é aquela que contempla tais variáveis, que, dedutivamente é específica para cada tipo litológico;

2 - Limites entre cristais - Rochas que apresentam as relações de contato entre minerais relativamente fracas podem apresentar micro descontinuidades nestes locais, refletindo assim a luz incidente em várias direções;

3 - Diferença angular entre a direção da serragem e a orientação dos cristais;

4 - Micro-fraturas preenchidas;

5 - Tipos de minerais que constituem a rocha.

\subsubsection{TÉCNICAS DE MEDIÇÃO DO BRILHO EM SUPERFÍCIES DE}

\section{ROCHA POLIDA.}

Para propósitos de engenharia, o termo superfície pode ser entendido como sendo o limite entre a peça trabalhada e o meio em que ela se encontra. A textura, ou rugosidade superficial, é definida por micro-descontinuidades deixadas na superfície do material trabalhado (Figura 2.4) decorrentes do processo de fabricação (CARPINETTI, et al., 2000). 


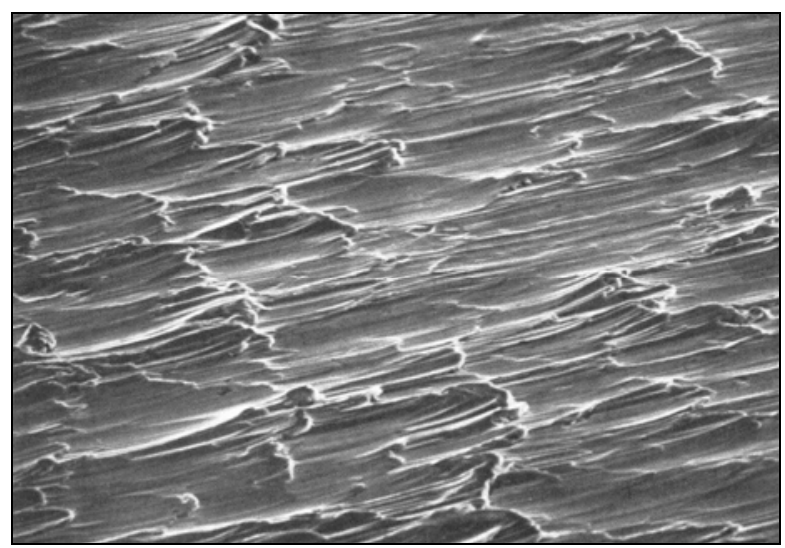

Figura 2.4 - Fotografia em MEV mostrando a superfície de uma folha de aço (MUMMERY, 1992).

O polimento de rochas ornamentais visa a transformação de mármores e granitos, feita através do atrito de rebolos abrasivos refrigerados com água em abundância, numa seqüência granulométrica definida, em que cada granulometria visa retirar as irregularidades deixadas pela antecessora. Tal procedimento visa conferir à superfície do material planicidade, fechamento e brilho (CETEMAG, 2003).

Um dos equipamentos mais utilizados para a medição do brilho é o Glossmeter (Figura 2.5). Tais equipamentos foram desenvolvidos baseados no procedimento padrão ditado pela norma ASTM D 523-94.

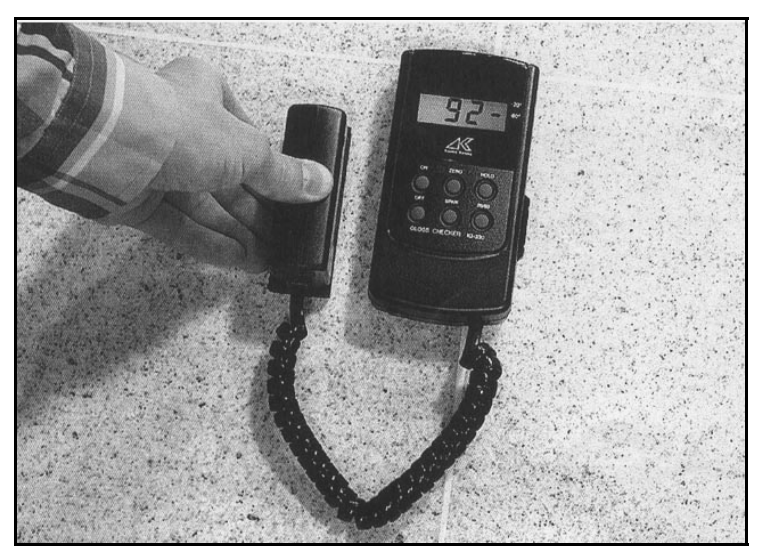

Figura 2.5 - Medidor de brilho (glossmeter) em ladrilho de granito (CETEMAG, 2003).

As superfícies de peças trabalhadas, independentemente de sua natureza e processos, por mais perfeitas que sejam, sempre apresentam irregularidades em relação à superfície geométrica ideal. A rugosidade influi no comportamento das superfícies em várias de suas 
utilizações como, por exemplo: atrito, ajuste, desgaste, corrosão, aparência, resistência à fadiga, propriedades ópticas, etc.

De acordo com ABNT-NB 93 (1964) os desvios da superfície real em relação à geométrica podem ser considerados:

1- $\quad$ Erros macrogeométricos (Erros de Forma): podem ser medidos com instrumentos de medição convencionais;

2- $\quad$ Erros microgeométricos (Rugosidade): só podem ser avaliados com o auxílio de aparelhos especiais (rugosímetros, perfilômetros, etc.).

A separação entre estes dois tipos de irregularidades de superfície é arbitrária.

Para a Engenharia Mecânica, em trabalhos de precisão, a rugosidade afeta várias propriedades físicas do material, como níveis de atrito, desgaste, tipos de lubrificação em peças de deslizamento, transmissão de calor, resistência mecânica, entre outras. Para uma superfície rochosa a rugosidade afeta o brilho final, o fechamento e conseqüentemente a durabilidade da placa. A rugosidade está intimamente relacionada à qualidade do processo que a rocha passou. Uma placa de rocha polida menos rugosa é sinônimo de maior qualidade final. Logo, a medição (ou controle) da rugosidade ao longo do processo de polimento é o melhor indicador de controle de qualidade nessa etapa de beneficiamento.

Rugosímetro é o nome genérico dado a aparelhos que medem a textura de uma dada superfície. Em geral, o desempenho de um rugosímetro é condicionado por vários fatores, que podem ser agrupados em determinadas propriedades (resolução, geometria stylus, etc). Os efeitos dos parâmetros podem ser plotados como linhas em gráficos que consideram a variação da amplitude e o comprimento de onda, para mostrar a melhor opção para medir determinada superfície (STEDMAN, 1987). Os resultados obtidos por um rugosímetro não são a expressão pura da realidade, mas sim a representação, o mais próximo possível, da realidade. Porém, caso o equipamento escolhido não seja o mais indicado para medir 
determinada superfície, o resultado será uma informação falseada a respeito da rugosidade da mesma (Figura 2.6). Defeitos na ponta stylus, como trincas, por exemplo, também poderão falsear os resultados medidos (Figura 2.7).

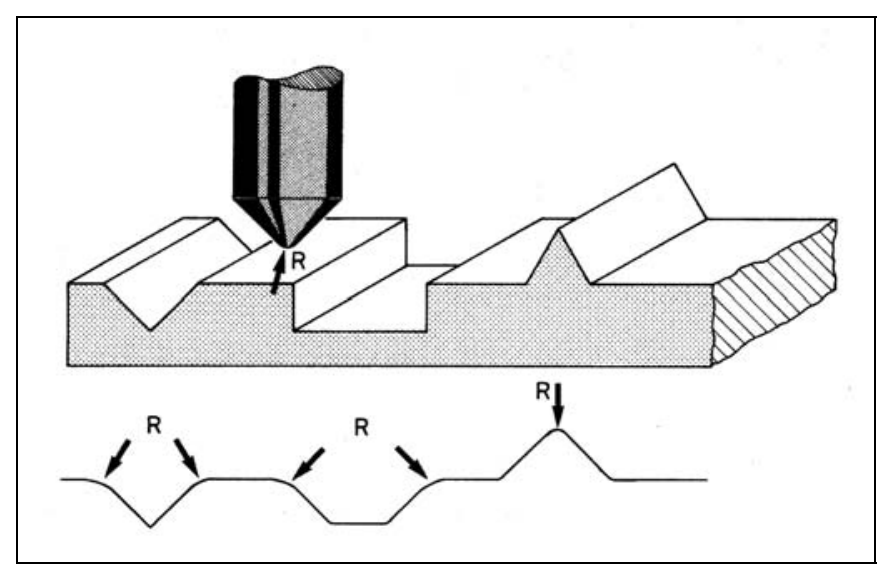

Figura 2.6 - Comparação entre uma superfície real e o perfil medido com uma ponta stylus (MUMMERY, 1992).

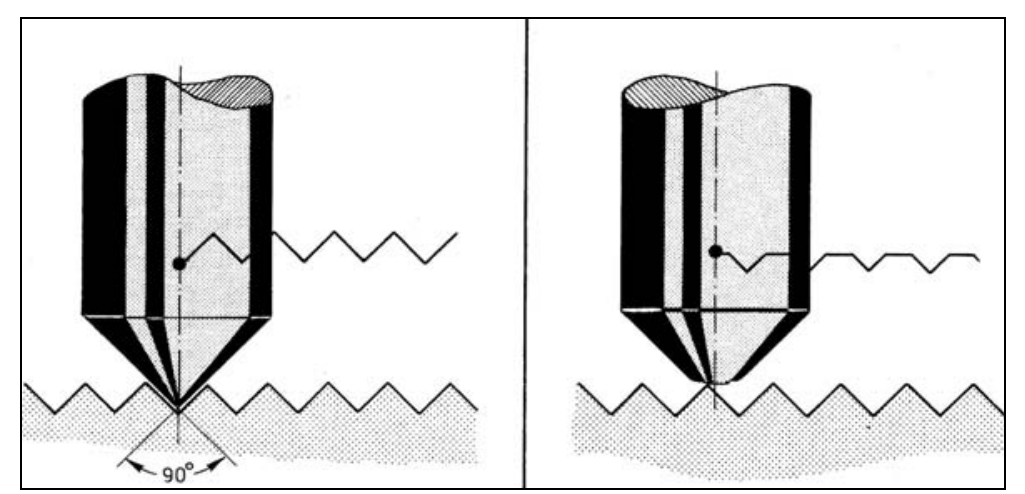

Figura 2.7 - Efeito de uma ponta stylus com defeito na medição da rugosidade (MUMMERY, 1992).

Existem vários métodos utilizados para a medição das irregularidades de uma superfície. Dentre tais métodos, um já citado, e que vem sendo utilizado com freqüência é o chamado método Stylus, sendo este idealizado inicialmente para a medição de imperfeições em superfícies de equipamentos mecânicos.

Blasi et al. (1995), realizaram ensaios com rochas ornamentais visando uma padronização européia para a determinação da qualidade do acabamento final de superfícies polidas utilizando o método stylus. Determinaram três principais tipos de irregularidades 
(Figura 2.8) que podem ocorrer e que interferem no brilho final de uma placa de rocha, a saber:

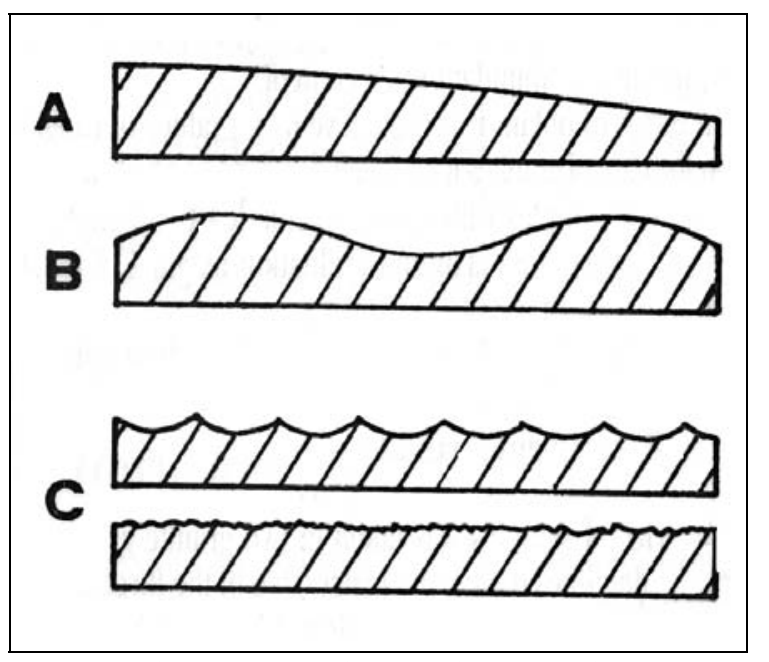

A) Forma “defeituosa”;

B) Forma ondulada;

C) Forma rugosa.

Figura 2.8 - Tipos de irregularidades de superficie (BLASI et al., 1995).

Estes três tipos de irregularidades foram definidos em função do comprimento de onda da superfície. A forma defeituosa ocorre quando o comprimento de onda da superfície é, pelo menos, mil vezes sua altura. Pode-se chamar de ondulação quando a razão entre o comprimento de onda e amplitude estiver entre cem e mil, enquanto que a forma rugosa é caracterizada quando esta relação variar entre cinco e cem.

A rugosidade de uma superfície é basicamente quantificada através de parâmetros relacionados à altura (amplitude) e largura (espaçamento) das irregularidades, ou uma combinação destes atributos. Existem inúmeros parâmetros referentes à rugosidade, não sendo objetivo deste trabalho, detalhar cada um. Porém, será apresentada uma relação dos parâmetros mais utilizados para a medida de irregularidades de superfícies. 


\subsection{DESGASTE}

A importância do atrito e da resistência ao movimento é reconhecida em vários exemplos práticos no nosso dia-a-dia e ao longo da História da nossa civilização. Registros do antigo Egito mostram serviços de transporte de objetos pesados que envolviam desde o simples arrasto, até a utilização de toras ou rolos. Para arrastar os blocos de várias toneladas que usavam em suas construções os egípcios utilizavam destas ferramentas simples para diminuir, de maneira ainda instintiva, o coeficiente de atrito entre as superfícies.

Em muitos setores das atividades humanas o desgaste é um fator indesejável, pois o mesmo pode causar perda da vida útil de algum componente, perda de desempenho, etc. No caso do polimento de rochas ornamentais, entretanto, é o desgaste da superfície rochosa que imprime o brilho, a beleza e a durabilidade destes materiais. Logo, é de suma importância a compreensão dos processos de atrito e desgaste envolvidos no polimento de rochas e a definição de um modelo tribológico, em que seja possível a definição de taxas de desgaste, sendo considerados todos os atributos intervenientes neste processo.

\subsubsection{INTRODUÇÃO A TRIBOLOGIA}

O termo Tribologia pode ser definido como sendo a "ciência e tecnologia de superfícies que se interagem em movimento relativo a das práticas a elas relacionadas". O atrito e o desgaste não são propriedades intrínsecas dos materiais, mas sim características da interação destes materiais com variáveis operacionais, sendo estes responsáveis, respectivamente, por dissipações de energia e matéria. $\mathrm{O}$ atrito é a resistência ao deslocamento e é gerado a partir da interação de sólidos em determinadas áreas de contato e o desgaste é a perda progressiva de material da superfície de um corpo sólido devido ao contato e movimento relativo deste com outro corpo sólido, líquido ou gasoso (ZUM GAHR, 1987). 
A resistência ao desgaste é considerada como parte de um sistema tribológico, sendo muitos os parâmetros que acabam por influir na taxa de desgaste, incluindo as características do projeto, condições de operação, tipo de abrasivo e propriedades do material (ZUM GAHR, 1987). A parte de modelagem analítica para previsão de taxas de desgaste será mostrada mais a frente.

De acordo com ASTM (2001) os fatores que mais influem num determinado sistema tribológico são:

- Composição dos materiais;

- Acabamento da superfície de cada sólido;

- Natureza das condições de contorno;

- Carga aplicada;

- Velocidade relativa entre os corpos;

- Natureza do movimento entre os corpos (unidirecional, para trás e para frente, etc.);

- Natureza do contato;

- Temperatura da região interfacial;

- Características da máquina a ser utilizada.

\subsubsection{TIPOS DE DESGASTE}

Existem inúmeras classificações de processos de desgaste. Uma característica em comum entre todas elas é o uso do mecanismo para definir o processo de desgaste. Noble (1985) caracteriza quatro tipos principais de desgaste, a saber:

- Desgaste abrasivo (abrasão);

- Desgaste por deslizamento;

- Desgaste erosivo (erosão); 
- Desgaste por atrito acelerado devido a vibrações diferenciais na zona interfacial (fretting).

Dentre estes tipos de desgaste, o que ocorre no processo de polimento de uma placa de rocha ornamental é o de abrasão.

Para Zum-Gahr (1987) o desgaste por abrasão se caracteriza por movimento relativo entre um corpo "duro" e uma superfície mais "mole". Neste processo, o corpo duro pode ser fraturado e a superfície mais mole pode ser trincada e/ou deformada, sendo tais materiais removidos da superfície, resultando mensurável perda de volume.

De acordo com este autor, o desgaste abrasivo pode, por sua vez, ser dividido em relação ao tipo de contato. Podem ser contatos a dois e a três corpos. O primeiro ocorre quando um abrasivo desliza ao longo de uma superfície, e o segundo quando um abrasivo desliza entre duas superfícies. A Figura 2.9 mostra, de forma esquemática, os dois tipos de processos abrasivos em relação ao contato.

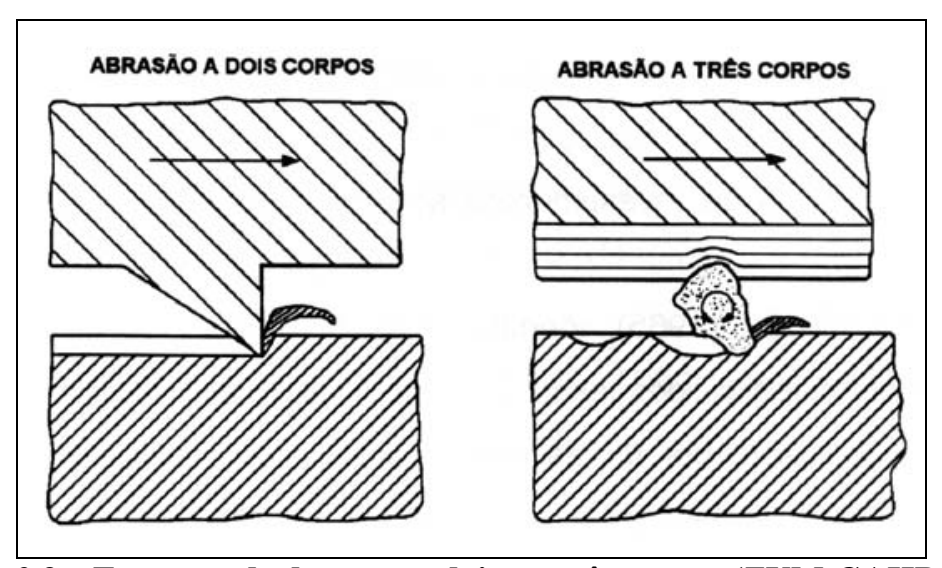

Figura 2.9 - Esquema de desgaste a dois e a três corpos (ZUM-GAHR, 1987).

O beneficiamento de uma peça com abrasivo preso ao rebolo (abrasão a dois corpos) é muito diferente se comparado ao processo que utiliza abrasivos soltos (abrasão a três corpos). Uma superfície gerada por desgaste abrasivo a dois corpos é mais lisa do que uma gerada por abrasivos livres. Comparado com os abrasivos livres, a rugosidade média (Ra) 
obtida por processo a dois corpos é de 1/5 a 1/10 (KUMAGAI et. al 1965 apud TOMITA e EDA, 1996) (Figura 2.10).

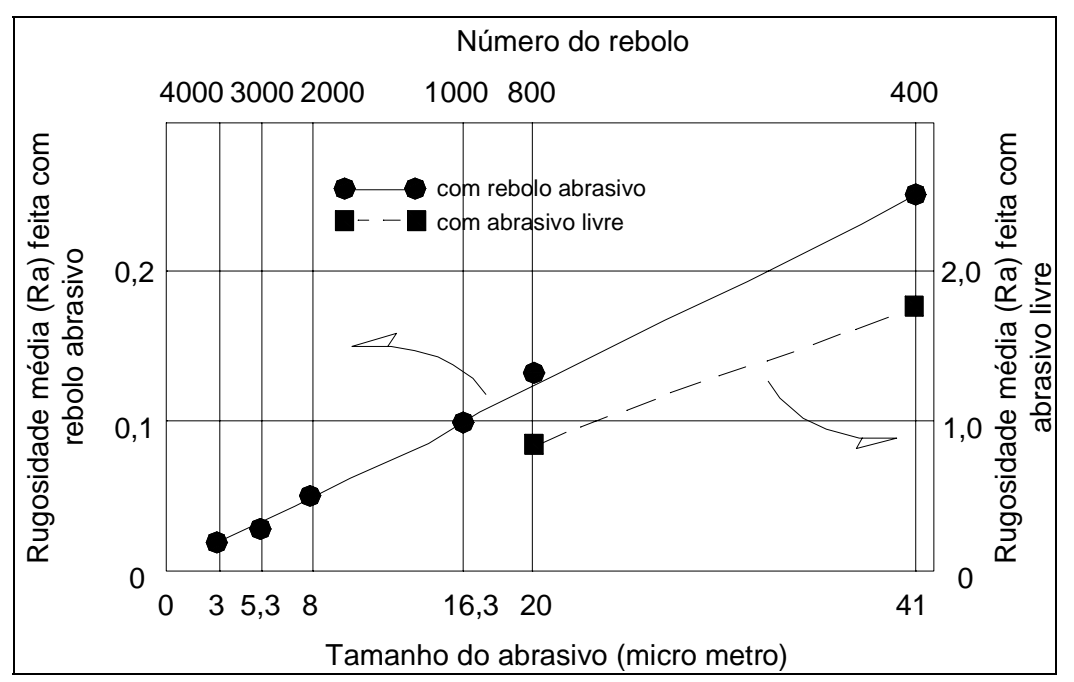

Figura 2.10 - Relação entre o tamanho do abrasivo, tipo de desgaste e rugosidade média (TOMITA e EDA, 1996).

O desgaste abrasivo pode também ser dividido em relação ao carregamento (tensão) em que o sistema apresenta, a saber:

- Abrasão por riscamento - Também conhecido com abrasão em baixas tensões, este tipo se dá por contato da superfície com partículas abrasivas, em que, devido à baixa tensão envolvida, não ocorre fragmentação do abrasivo. As tensões causadas são devidas, principalmente, a velocidade relativa entre os corpos (velocidade de corte);

- Abrasão por goivamento - Devido às altas tensões envolvidas neste processo, o goivamento envolve a remoção de partículas relativamente grosseiras da superfície do corpo. Este tipo de desgaste envolve a fragmentação das partículas abrasivas e remoção de grande quantidade de material da peça de trabalho (RABINOWICZ, 1966). 


\subsubsection{TIPOS DE ABRASIVOS}

O termo abrasivo pode ser definido como sendo uma partícula ou grão capaz de causar rápido ou eficiente desgaste em uma superfície sólida (STACHOWAIAK e BATCHELOR, 1993).

A palavra abrasão provém do latim "abradere" o que significa arrancar partículas de um material por atrito com outro material, quase sempre mais duro (CETEMAG, 2003).

A capacidade de determinado abrasivo em remover material submetido ao processo de desgaste é chamada de abrasividade.

De acordo com o tipo de obtenção, os abrasivos podem ser classificados como:

- Abrasivos naturais não silicosos: - Diamante;

- Coríndon;

- Abrasivos naturais silicosos: - Quartzo;

- Granada;

- Pó vulcânico;

- Diatomita.

- Abrasivos naturais moles: $\quad$ - Feldspato;

- Dolomita;

- Óxido de estanho (potéia);

- Óxidos metálicos (Cr, Zn, etc.) 
- Abrasivos artificiais: - Diamante industrial;

- Nitreto cúbico de Boro;

- Carbeto de Boro;

- Carbeto de Silício;

- Carbeto de Tungstênio;

- Óxido de Alumínio (alumina).

No setor de Rochas Ornamentais os abrasivos para polimento são divididos em dois grupos, a saber:

- Abrasivos Magnesianos - Usa como ligante o Óxido de Magnésio e como elemento abrasivo o Carbeto de Silício (SiC), também conhecido como "carborundum”. O Carbeto de Silício apresenta ligação covalente e é caracterizado por ser muito duro (9,5 na escala de Mohs), infusível e quimicamente inerte. Este composto é produzido a partir do aquecimento de quartzo ou areia com excesso de coque, num forno elétrico a $2.000-2.500{ }^{\circ} \mathrm{C}$, de acordo com a seguinte reação:

$$
\begin{gathered}
\mathrm{SiO}_{2}+2 \mathrm{C} \rightarrow \mathrm{Si}+2 \mathrm{CO} \\
\mathrm{Si}+\mathrm{C} \rightarrow \mathrm{SiC}
\end{gathered}
$$

$\mathrm{O} \mathrm{SiC}$ é muito pouco reativo e não é atacado por ácidos (exceto $\mathrm{H}_{3} \mathrm{PO}_{4}$ ). Geralmente apresenta cor púrpura escura, preta ou verde escura, devido a pequenas quantidades de ferro e outras impurezas, mas amostras puras são amarelas pálidas ou incolores. Apresenta uma estrutura tridimensional de átomos de $\mathrm{Si}$ e $\mathrm{C}$, sendo cada átomo rodeado tetraedricamente por quatro átomos do outro tipo. Há um grande número de formas cristalinas, baseadas nas estruturas do diamante ou da wurtzita (LEE, 1996). 
Estes abrasivos são fabricados em todas as granas necessárias ao beneficiamento de chapas, do \#16 ao \#1200 mesh (Figura 2.11). De tecnologia ultrapassada, estão sendo destinados àqueles que utilizam máquinas de polimento manual ou semi-automáticas. As empresas possuidoras de politrizes automáticas praticamente aboliram sua utilização nos primeiros satélites, que vão da grana (mesh) 16 ao 120 .

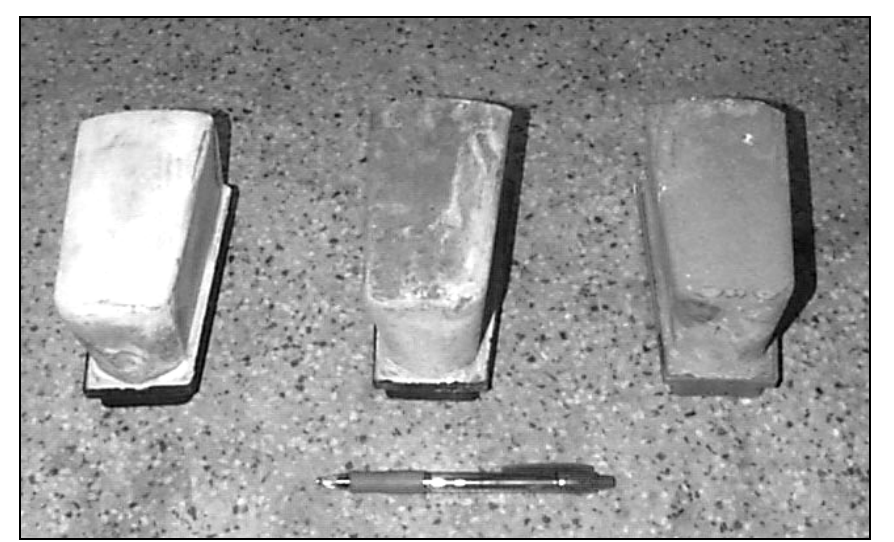

Figura 2.11 - Rebolos abrasivos magnesianos utilizados no polimento de rochas ornamentais (Foto do Autor).

- Abrasivos Diamantados - Fabricados em liga de ferro e cobalto (ente outros metais) ou em resina epoxídica, estes abrasivos são os que representam a maior evolução tecnológica dos últimos anos referente a polimento de rocha. Utilizados a cerca de dez anos na Europa e a cerca de 5 anos no Brasil, estes abrasivos trazem inúmeras vantagens na sua utilização em máquinas multi-cabeças. Os principais ganhos que este material pode dar são: aumento de produtividade e qualidade final, melhor qualidade da água reciclada, diminuição no consumo de energia elétrica, menor pressão de trabalho, redução do tempo morto, entre outras. Este tipo de abrasivo é muito eficiente em remover marcas de chapas mal serradas (CETEMAG, 2003).

Xie \& Bhushan (1996), estudando o diamante e a alumina no polimento de metais, verificaram que as partículas de alumina causaram menor desgaste e produziram uma superfície mais rugosa no material do que o diamante. 


\subsubsection{PRINCIPAIS FATORES QUE INFLUEM NA ABRASIVIDADE}

De acordo com Momber e Kovacevic (1998), a avaliação de um material para ser usado como abrasivo deve envolver a caracterização dos seguintes parâmetros:

- Estrutura do material;

- Dureza do material;

- Comportamento mecânico;

- Forma do grão;

- Distribuição granulométrica;

- Tamanho médio dos grãos.

Agus et al. (1995 e 1996) introduziram um parâmetro para a avaliação do material abrasivo:

$$
P_{A b r}=H_{p} \cdot S \cdot \rho_{p} \cdot d_{p} \cdot m_{A} \text { onde: }
$$

Hp - Dureza do material abrasivo;

$\mathrm{S}$ - Forma da partícula;

$\rho$ - Peso específico do material;

d - Diâmetro da partícula;

$\mathrm{m}$ - Taxa de fluxo de massa.

\section{DUREZA}

A dureza é a resistência que determinada superfície oferece ao risco, sendo esta considerada como uma das propriedades mais importantes do material que sofre desgaste. Cabe salientar que quando se fala de dureza, pode estar se tratando tanto do abrasivo quanto do material a ser desgastado. 
Como as outras propriedades físicas dos minerais, a dureza depende da estrutura atômica do mesmo. Quanto mais forte for a união entre os átomos, mais duro será o material (DANA, 1983).

Albertin e Filho (1994), estudando a relação entre a dureza de dois diferentes abrasivos (hematita e quartzo) com o desgaste de bolas de ferro fundido concluíram que as maiores perdas de massa de ferro fundido ocorreram nos ensaios com quartzo. Tal mineral apresenta valor 7 na escala de Mohs, enquanto que a hematita apresenta valores entre 5,5 e 6,5 .

A dureza pode ser quantificada através de vários métodos. Um dos métodos mais utilizados para medir a dureza de materiais, principalmente ligas e metais, são os ensaios de Rockwell, normatizado pela ASTM E 18. Diversas escalas podem ser utilizadas a partir de combinações possíveis de vários penetradores de diferentes cargas, as quais permitem o ensaio de virtualmente todos os metais e ligas, desde os mais duros até os mais macios. Os penetradores incluem esferas de aço endurecido com diâmetros de 1/16, 1/8, 1/4 e 1/2 polegada $(1,588,3,175,6,350$ e $12,70 \mathrm{~mm})$, e um penetrador cônico de diamante (Brale) que é usado para os materiais mais duros (CALLISTER, 2000).

Nos ensaios de dureza Brinell, como nas medições Rockwell, um penetrador esférico e duro é forçado contra a superfície do metal a ser testado. O diâmetro do penetrador de aço endurecido (ou carbeto de tungstênio) é de 10,00 mm (0,394"). As cargas padrões variam entre 500 e $3000 \mathrm{~kg}$, em incremento de $500 \mathrm{~kg}$; durante o ensaio, a carga é mantida constante por um tempo específico (entre 10 e 30 segundos). Materiais mais duros exigem cargas aplicadas maiores. O índice de dureza Brinell, HB, é uma função tanto da magnitude da carga quanto como do diâmetro da impressão resultante (CALLISTER, op. cit).

Em rocha, uma técnica que vem sendo cada vez mais utilizada é a determinação da dureza por microindentação, também chamada de microdureza. Existem dois tipos principais 
de pontas de diamante, que são adotadas em função do tipo de mineral que será efetuado o ensaio (Figura 2.12). A ponta Vickers não apresenta um bom resultado em materiais não maleáveis, como vidro, cerâmica, e minerais não metálicos (grande maioria dos minerais encontrados em rochas ornamentais). Pesquisas do setor ceramista mostraram que a determinação da dureza Knoop apresentava uma menor dispersão do que as medidas de dureza Vickers, para os mesmos materiais (ULNER, GERMAK, LE DOUSSAL, 2001 apud QUITETE, 2002).

A ponta no formato Knoop apresenta uma forma alongada, sendo mais indicada para minerais menos maleáveis que os metálicos, como por exemplo, o quartzo (QUITETE \& RODRIGUES, 1998).

Em materiais dúcteis, como minerais metálicos e polímeros, a dureza de micro impressão, tanto Vickers quanto Knoop, é determinada com uma extensa gama de cargas, comumente de $0,049 \mathrm{~N}$ a $19,6 \mathrm{~N}$ ( $5 \mathrm{gf}$ a $2 \mathrm{kgf}$ ). Em materiais quebradiços, como os minerais não-metálicos e cerâmicos, a utilização de cargas elevadas gera um fissuramento intenso, o que impede uma leitura confiável das diagonais; por isso em tais materiais é comum a utilização de cargas inferiores a 1,96N (QUITETE, 2002).
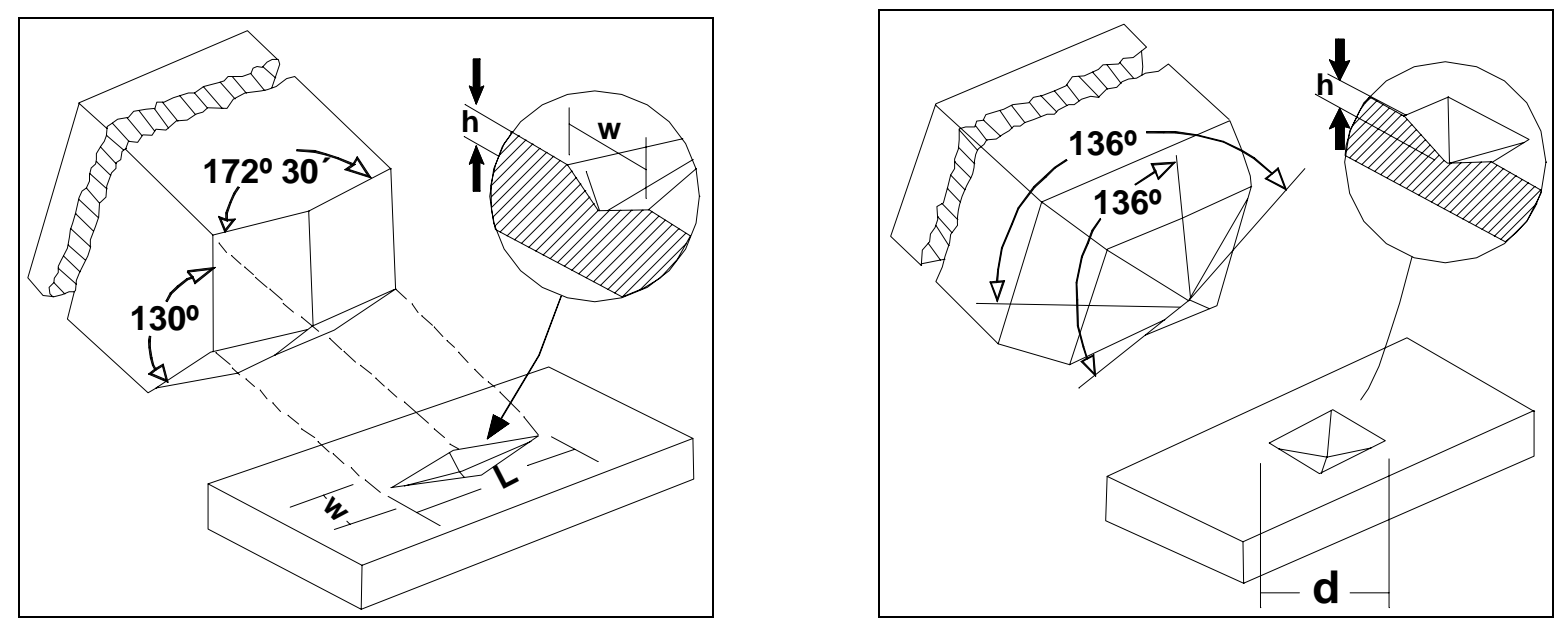

Figura 2.12 - Dois dos principais tipos de ponta de diamante utilizados para microindentação: Knoop (á esquerda) e Vickers (à direita). 
Quitete (2002) trabalhando com a dureza Knoop com o objetivo de correlacioná-la com resultados de desgaste Amsler criou um esquema para a realização das medições de microdureza (Figura 2.13). Neste trabalho o autor concluiu que "os valores obtidos na microindentação e no ensaio Amsler apresentaram uma proporcionalidade direta, ou seja, quanto maior a dureza menor o desgaste. Entretanto, essa associação não é precisa, sendo baixa a correlação entre estas duas propriedades $\left(R^{2}=0,49\right.$ para $H K_{25}$ e 0,32 para $\left.H K_{\text {média }}\right)$.

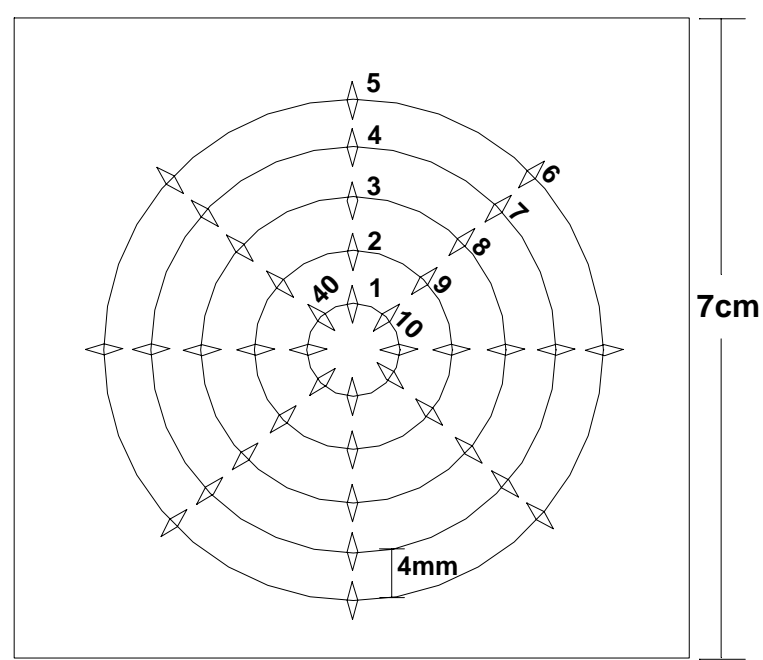

Figura 2.13 - Esquema utilizado para a realização da caracterização da microdureza em placas de rochas ornamentais (QUITETE, 2002).

O mesmo autor mostra que os principais parâmetros obtidos da determinação da

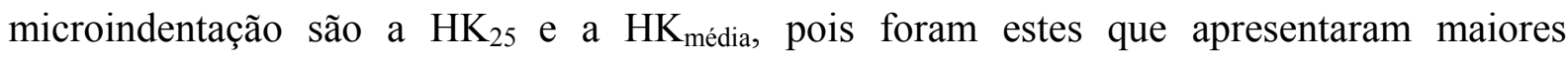
correlações com outros indicadores, como granulação, desgaste e teor de quartzo. Ele propõe ainda, a utilização da dureza knoop na previsão da durabilidade do lustro das rochas submetidas ao tráfego de pedestres.

Gong e Guan (2001), enfatizam que, no ensaio knoop, quando ocorre um pequeno carregamento, o valor da dureza tende a ser mais alto se comparado com valores de dureza obtidos a partir de carregamentos maiores. Tal fenômeno está relacionado ao chamado "efeito do tamanho de indentação" (ISE) e que, para realmente se conhecer a dureza de um material, se faz necessário uma completa caracterização quantitativa deste fenômeno. 
Callister (2000) apresenta um quadro comparativo entre os diferentes métodos utilizados para a determinação da dureza em diferentes tipos de material (Figura 2.14).

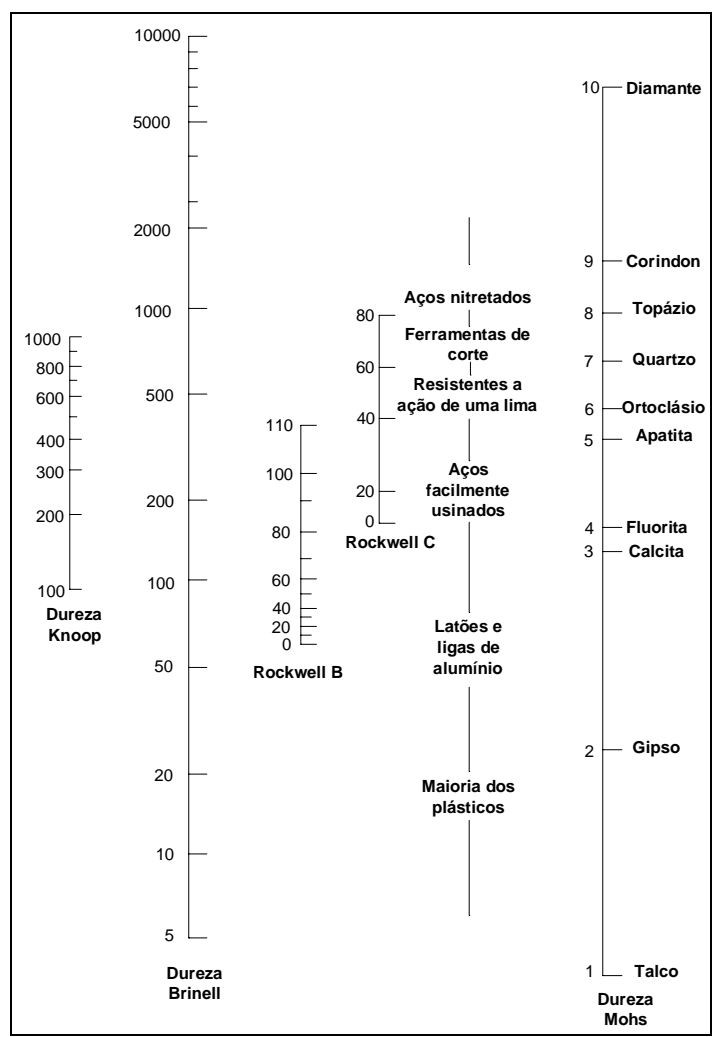

Figura 2.14 - Comparação entre várias escalas de dureza (Adaptado de KINNEY, 1957 apud CALLISTER, 2000).

Em relação à característica de dureza do abrasivo relacionado com o processo de polimento de rochas ornamentais, Scognamiglio (1995) lembra que tal fator é importante, porém, não o único atributo que deve ser considerado. Segundo o autor, ao utilizar abrasivos muito duros, a pressão usual de trabalho da politriz será ineficiente e, no intuito de torná-lo produtivo, pode-se aumentar gradualmente a pressão de trabalho do equipamento, o que acarreta distanciamento dos padrões normais da máquina, o que pode gerar vários problemas, pois com o aumento da pressão de trabalho:

- aumenta-se a amperagem dos motores;

- cresce o consumo de energia elétrica;

- chapas e abrasivos começam a se romper mais freqüentemente;

- aumenta substancialmente o número de riscos na chapa; 
- ladrilhos de $1 \mathrm{~cm}$ de espessura não resistem à altas pressões;

- motores elétricos passam a trabalhar em regime de sobrecarga e, por conseguinte, vão aquecer e queimar mais freqüentemente;

- cabeçotes terão uma redução drástica de sua vida útil devido aos excessivos esforços sobre os rolamentos, provocando também superaquecimento e fuga de graxa;

Este autor lembra que o princípio do trabalho do abrasivo não é o da pressão e sim o da diferença de dureza entre seu componente básico, o Carbeto de silício ( $\mathrm{SiC}$ ) - dureza 9,5 na escala de Mohs - e o granito que, mesmo o mais duro não ultrapassa o índice 7 na mesma escala. Deve-se então estabelecer uma faixa de pressão de trabalho entre 1 Bar e, no máximo, 2 Bars $\left(1 \mathrm{Bar}=0,987 \mathrm{~atm}\right.$ ou $\left.1 \mathrm{kgf} / \mathrm{cm}^{2}\right)$. Se algum abrasivo necessitar de pressão superior a 2 Bars para se tornar produtivo, convém também considerar os fatores negativos que advém desta pressão.

\section{TAMANHO DAS PARTÍCULAS}

Santana e Mello (1994) verificaram que quanto maior o tamanho da partícula maior a taxa de desgaste. Isto é devido a uma remoção mais eficiente de material face à maior carga exercida por cada partícula de abrasivo quando, sob as mesmas condições de ensaio, o tamanho desta é aumentado.

Misra e Finnie (1983) analisando a resistência de metais puros para diferentes tamanhos de abrasivos, também notaram que a taxa de desgaste é crescente com o aumento do tamanho das partículas abrasivas até próximas de $100 \mu \mathrm{m}$. Acima deste tamanho o crescimento da taxa de desgaste tende a diminuir. De modo geral, pode-se dizer que a resistência ao desgaste é inversamente proporcional ao tamanho do abrasivo. 
Tomita e Eda (1995) mostram que a taxa de remoção de material apresenta uma relação constante com abrasivos até o rebolo com granulometria $800(20 \mu \mathrm{m})$. A partir deste ponto ocorre uma grande diminuição na taxa de remoção (Figura 2.15).

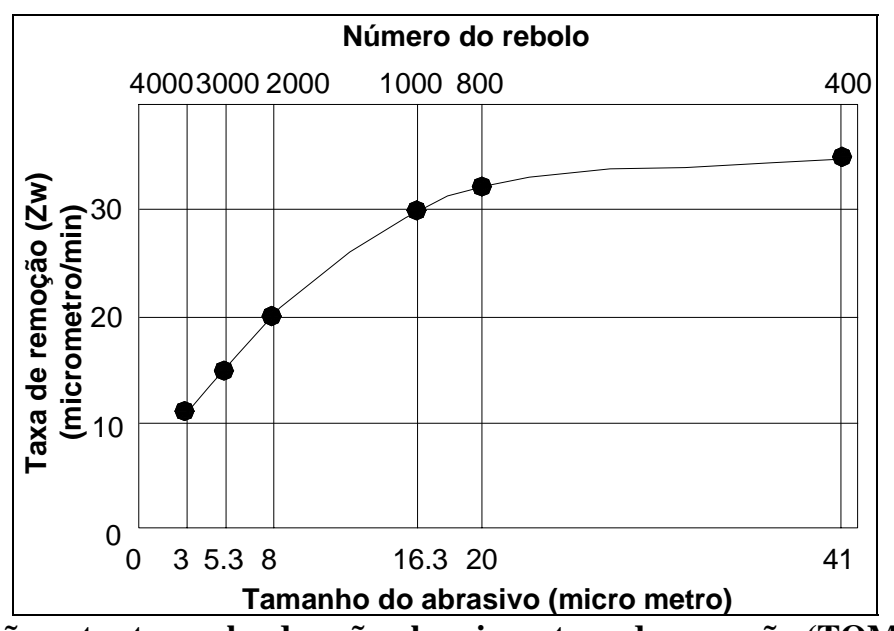

Figura 2.15 - Relação entre tamanho do grão abrasivo e taxa de remoção (TOMITA e EDA, 1996).

Os mesmos autores estudaram também a relação entre a rugosidade máxima $\left(R_{\max }\right)$ e o tamanho do grão abrasivo. Tal parâmetro se apresentou constante ao longo de todo o processo de polimento (Figura 2.16). Algumas equações foram desenvolvidas, a partir dos dados por eles apresentados, relacionando rugosidade média $\left(R_{\mathrm{a}}\right)$, taxa de remoção $\left(\mathrm{Z}_{\mathrm{w}}\right)$ e tamanho do grão abrasivo (D) e são apresentadas a seguir:

$$
R a=0.006 D+0.002
$$

$$
Z_{w}=1.8 D+5.6
$$




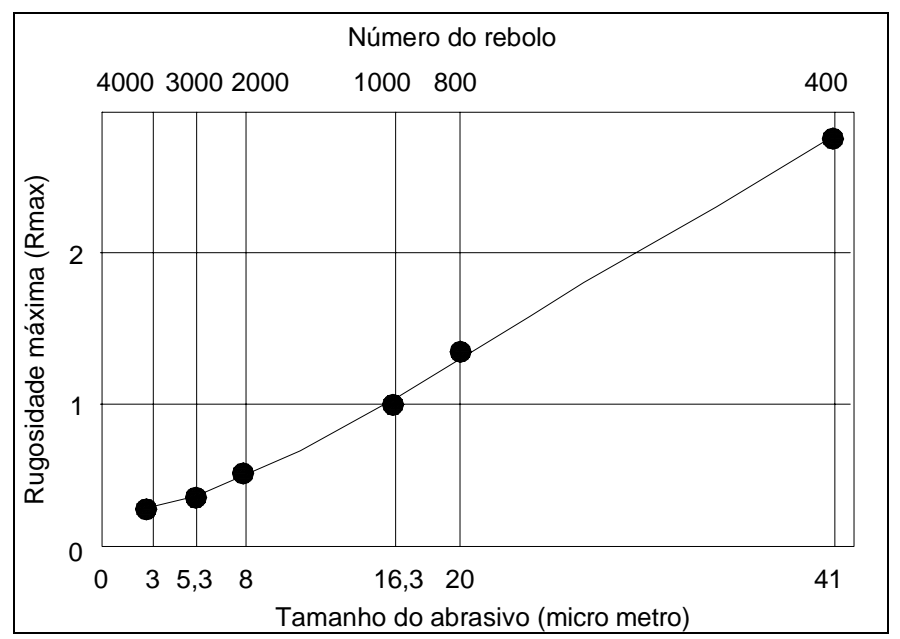

Figura 2.16 - Relação entre tamanho do abrasivo e rugosidade máxima (Rmax) (TOMITA e EDA, 1995).

\section{TENSÃO ENVOLVIDA NO PROCESSO DE DESGASTE}

Durante a abrasão, o tamanho das partículas pode variar em função das solicitações imperantes no sistema (Figura 2.17). Partículas muito duras e frágeis tendem a diminuir de tamanho, diminuindo também, o seu poder de desgaste. Partículas com alta tenacidade podem gerar arestas de corte arredondadas e deixarem de remover material por microcorte; e partículas com propriedades intermediárias, duras, porém não tão frágeis, podem ter arestas de corte renováveis durante seus movimentos, permitindo um desgaste rápido do material em contato (STACHOWAIAK e BATCHELOR, 1993).

O conceito oposto ao da tenacidade é o de friabilidade, que corresponde à facilidade para se romper um material sob uma determinada força ou impacto. A friabilidade define bem uma classificação dos abrasivos: materiais de maior friabilidade são utilizados em operações de retífica e de polimento (ex.: $\mathrm{SiC}$ e alumina eletrofundida branca), já os materiais menos friáveis (ex.: alumina eletrofundida marrom) são utilizados em operações envolvendo grande volume de material a ser removido (MORAIS e SUSTER, 2001). 


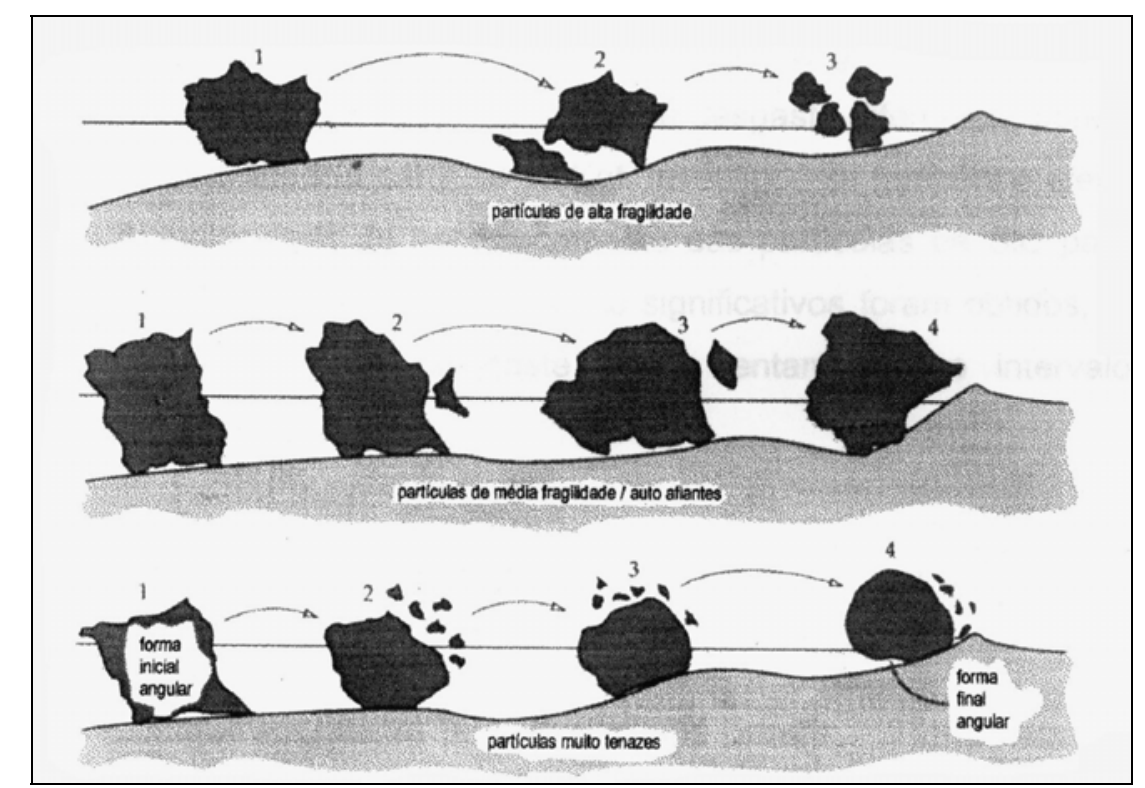

Figura 2.17 - Efeito da tenacidade e da fragilidade da partícula sobre sua eficiência em desgastar (STACHOWAIAK e BATCHELOR, 1993).

\section{VELOCIDADE RELATIVA E CARGA APLICADA}

A influência da carga aplicada e da velocidade relativa entre as partículas abrasivas e o material que sofre desgaste despertou interesse logo nos primeiros estudos de desgaste por abrasão.

Um dos primeiros trabalhos acerca deste assunto foi o de Haworth (1949). Este autor, ensaiando amostras temperadas de aço SAE 1045, variou a carga e a velocidade da roda de borracha. Foi possível observar que a mudança na velocidade de $250 \mathrm{rpm}$ para $1035 \mathrm{rpm}$, mantendo-se constante os outros parâmetros, gerou um aumento de, aproximadamente, duas vezes na taxa de perda de massa; enquanto que, dobrando-se a carga e mantendo a velocidade constante a $250 \mathrm{rpm}$, ampliou-se o valor da taxa de desgaste do abrasivo em duas vezes e meia. 


\section{TEMPERATURA}

O aumento da temperatura, geralmente, causa uma diminuição na dureza do material. Por este motivo é de se esperar que a temperatura influa na resistência ao desgaste dos materiais (TYLCZAK, 1992).

Apesar disto, poucos trabalhos têm sido realizados para quantificar o efeito da temperatura na abrasão, pois muitas dificuldades são encontradas pelos laboratórios para adaptar os equipamentos de tal forma que permitam a realização de ensaios a temperaturas controladas. Morais e Suster (2001), trabalhando com polimento de materiais cerâmicos, citam que outra propriedade que o abrasivo deve apresentar é a refratariedade, pois durante o trabalho do grão sobre uma superfície, grande quantidade de calor é gerada e sendo o material refratário, o desempenho e a vida útil do mesmo aumentam.

\subsubsection{MODELOS ANALÍTICOS DO PROCESSO ABRASIVO}

Existem alguns trabalhos voltados ao desenvolvimento de modelos analíticos que estudam a dinâmica do contato entre partículas abrasivas e superfícies de materiais, visando principalmente, a quantificação das taxas de desgaste.

Um dos primeiros modelos criados para a compreensão do mecanismo de desgaste foi o elaborado por Archard (1959, apud Tylczac, op. cit.). Tal modelo tenta quantificar o desgaste volumétrico (W), devido a passagem de uma partícula abrasiva sobre uma superfície com uma carga normal $\left(\mathrm{F}_{\mathrm{N}}\right)$, uma distância percorrida $(\mathrm{S})$ e a dureza da superfície desgastada (H). Tal modelo ficou conhecido como a Lei de Desgaste de Archard e pode ser expressa pela seguinte equação:

$$
W=K \cdot F_{N} \cdot S / H
$$


O $K$ desta equação é conhecido como "coeficiente de desgaste" e é função da forma, tamanho, tipo e distribuição das asperidades. Esta equação foi formulada para desgaste por adesão, porém, pode ser utilizado para o desgaste abrasivo a dois corpos.

Rabinowicz (1965) apud Stachowaiak e Batchelor (1993) considerou uma única partícula abrasiva, de forma cônica, sendo arrastada sobre uma superfície produzindo uma ranhura uniforme (Figura 2.18). De acordo com este modelo, o volume de material removido (W) é o produto entre a área da seção transversal do sulco produzido, $\left(d^{2} \cdot \cot \alpha\right)$ e a distância percorrida pelo indentador cônico (I).

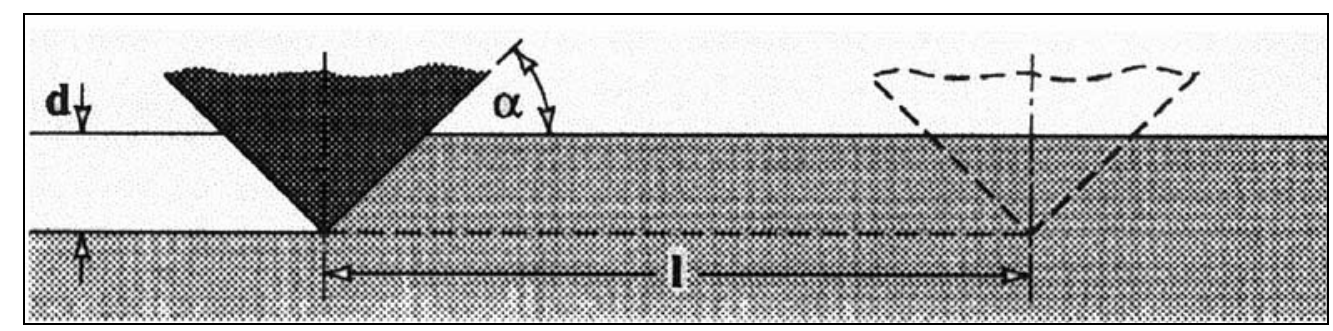

Figura 2.18 - Modelo de desgaste abrasivo causado por uma única partícula (RABINOWICZ, 1965 apud STACHOWAIAK e BATCHELOR, 1993).

$$
W=d^{2} \cdot \cot \alpha \cdot S \quad \text { (1) onde: }
$$

W - volume de material removido;

d - Profundidade da indentação;

$\alpha$; - ângulo do cone;

$\mathrm{S}$ - distância percorrida pelo indentador cônico. 


\subsection{TECNOLOGIA DE BENEFICIAMENTO FINAL}

O termo beneficiamento final pode ser entendido como todas as tecnologias aplicadas nos processos que conferem as características dimensionais, de conformação e especificação ao produto final. Assim, estão reunidos neste estágio os processos de acabamento superficial ou polimento (que ressaltam a coloração, a textura e a aparência do material), o corte (que lhes conferem as dimensões, formas e desenhos), os acabamentos de bordas e outros especiais. Embora não esteja no escopo de trabalho da Geotecnia, o processo mecânico de polimento merece ser estudado com atenção, visto que são as máquinas de polir que imprimem à rocha suas propriedades de brilho e de fechamento, sendo a identificação das variáveis operacionais que influem no processo de polimento de suma importância para um entendimento completo da interação entre os abrasivos e as rochas. Dentre tais processos será detalhado o de acabamento superficial, que será o tema central da pesquisa.

\subsubsection{HISTÓRICO DA EVOLUÇÃO TECNOLÓGICA DE POLITRIZES}

Desde a década de trinta, quando se iniciou o processo de polimento de mármores e similares, em escala industrial, no início com uso de areia e posteriormente de carbeto de silício, até o final dos anos sessenta, a técnica de polimento e lustro de rochas ornamentais pouco evoluiu. As evoluções apresentadas ocorreram, basicamente, na forma de acionamento e na construção das politrizes manuais (Figura 2.19), que funcionavam com um grande prato giratório, como responsável pelo movimento e contato do elemento abrasivo com o material polido. 


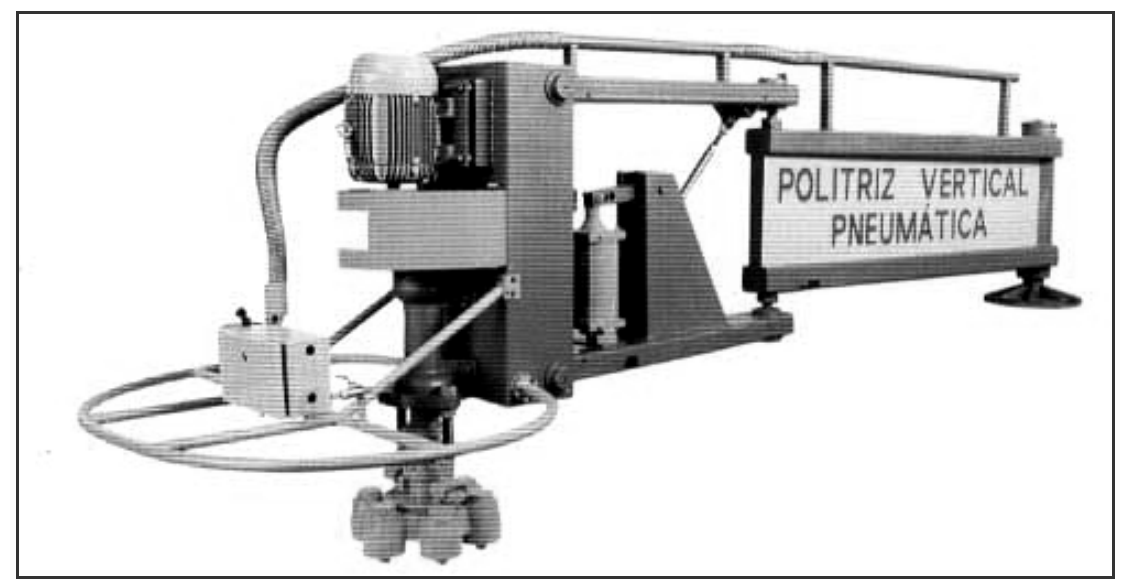

Figura 2.19 - Modelo de politriz manual (CETEMAG, 2003).

Este equipamento é constituído de uma coluna que sustenta um braço, o qual tem na sua extremidade o conjunto cabeçote onde são fixados os rebolos abrasivos. As chapas de rocha são colocadas deitadas sobre bancadas fixas de concreto, construídas ao lado da coluna de sustentação do braço da politriz.

Apesar de serem as primeiras máquinas utilizadas para o polimento de placas de rocha, são ainda muito empregadas, sobretudo nas pequenas marmorarias, cujo volume de produção (1 a $2 \mathrm{~m}^{2} /$ hora, dependendo do operador e da qualidade da superfície serrada) não justifica o investimento em equipamentos mais modernos.

Nas politrizes manuais a pressão do cabeçote e a trajetória do seu movimento sobre a superfície a ser polida dependem exclusivamente da ação direta do operador. Por este fato, são freqüentes as variações da qualidade do polimento ao longo de uma mesma chapa.

Devido às limitações em termos de qualidade do produto e produtividade, o uso destas politrizes é bastante restrito, não sendo recomendadas para empresas de beneficiamento que desejam trabalhar com produtos de alta qualidade e elevado nível de produção. Porém, mesmo em indústrias maiores e modernas, é comum a existência destes equipamentos, pois existe sempre um volume de chapas onde defeitos originados da serrada ou a presença de micro trincas, não se recomenda o polimento em politriz de esteira, pois o risco de quebra é muito elevado (KASCHNER, 1996). 
No final dos anos 60 e início da década de 70 surgiu a politriz de esteira para mármore, para o polimento de ladrilhos ou produtos já cortados em dimensões menores do que as chapas originadas do corte com o tear (Figura 2.20). O polimento de peças com pequenas dimensões era possível porque estas não se quebravam tão facilmente quanto às chapas, quando submetidas a pressões de trabalho mais altas, necessárias ao polimento automatizado.

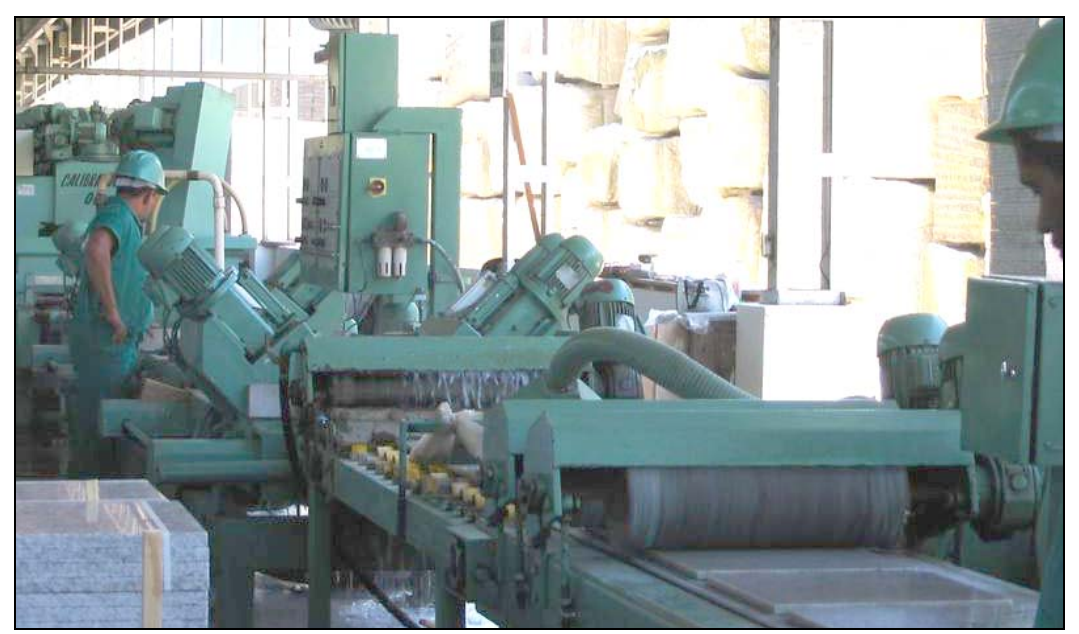

Figura 2.20 - Linha de produção em ladrilhos: da calibração ao polimento (CETEMAG, 2003).

Em meados dos anos 70 surgiram as politrizes de ponte móvel com bancada fixa (Figuras 2.21, 2.22 e 2.23). São equipamentos constituídos de um conjunto moto redutor, que aciona um cabeçote de polimento, suportado por uma ponte que se desloca sobre trilhos, obtendo-se assim uma variedade de movimentos simultâneos sobre a superfície a ser polida, semelhante ao aplicado pelo operador na politriz manual e ainda podendo-se imprimir uma pressão de trabalho uniforme, constante e mais elevada. 


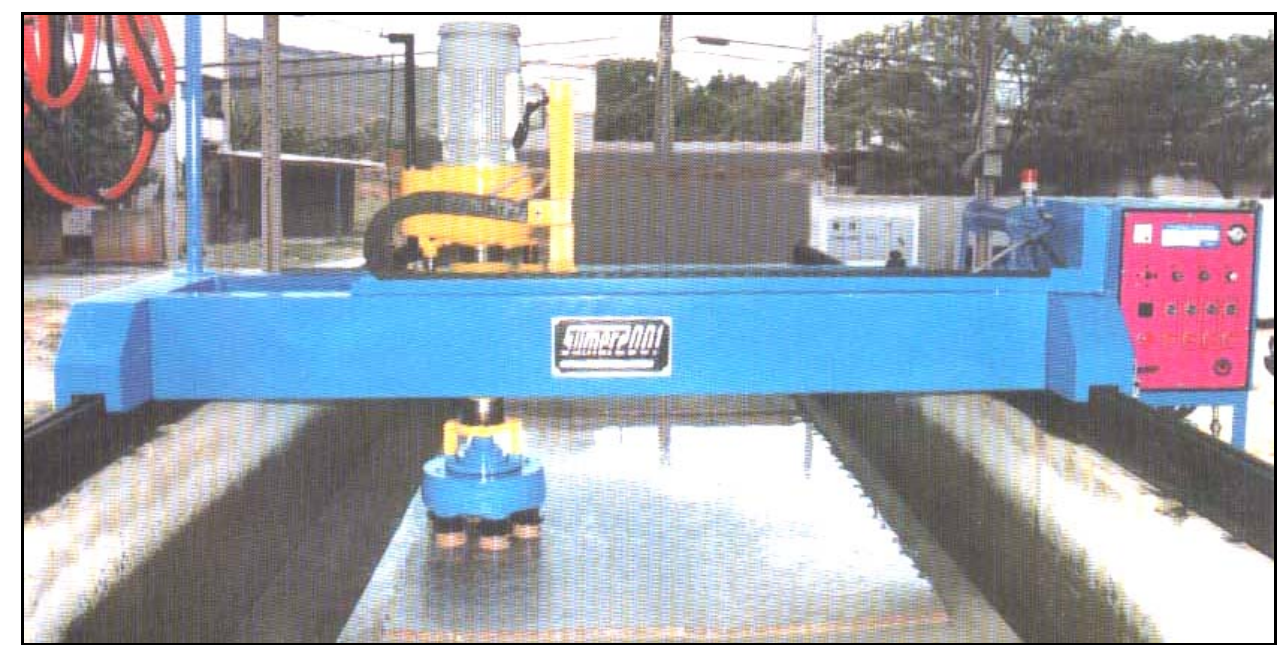

Figura 2.21 - Exemplo de politriz de ponte móvel de um cabeçote (CETEMAG, 2003).

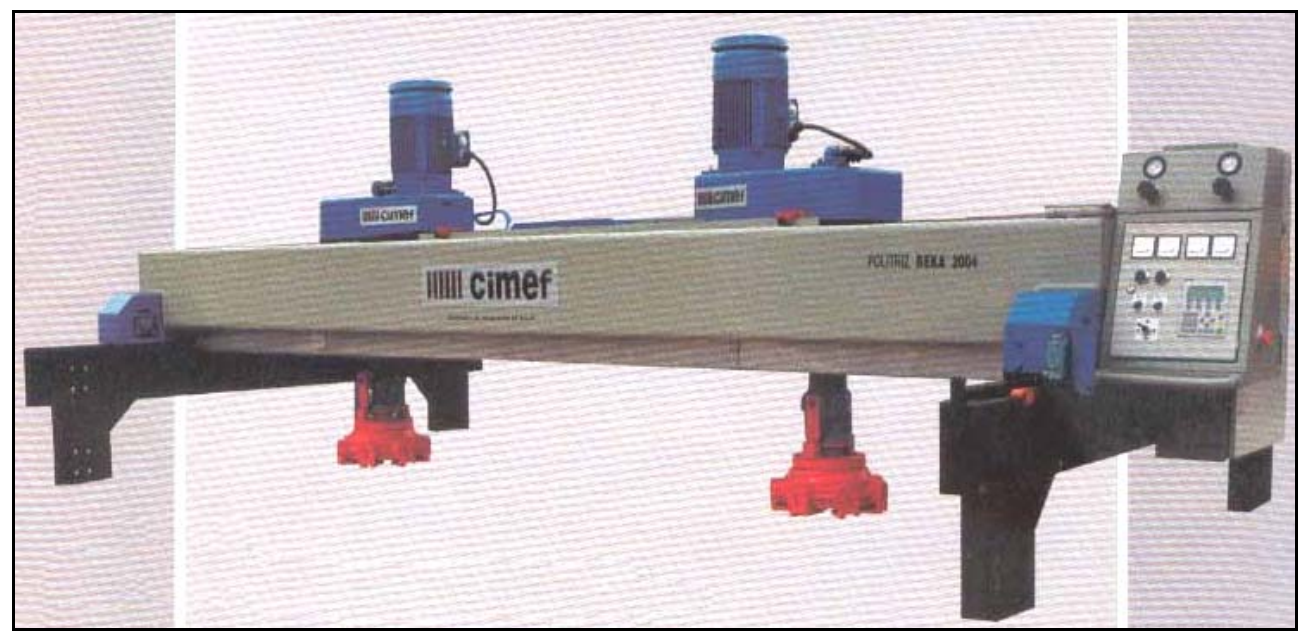

Figura 2.22 - Exemplo de politriz de ponte móvel de dois cabeçotes (CETEMAG, 2003).

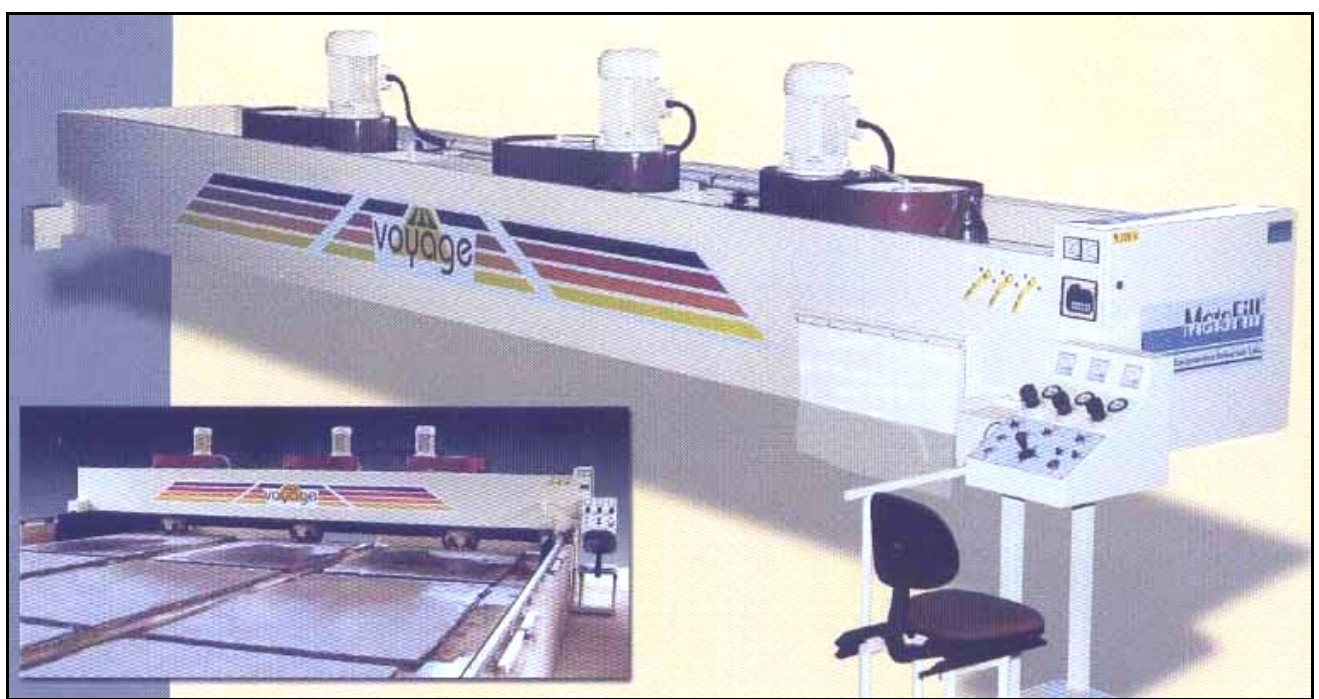

Figura 2.23 - Exemplo de politriz de ponte móvel de três cabeçotes (CETEMAG, 2003). 
Embora tenha sido inegável o avanço no processo de polimento de granitos com a politriz de ponte, a mesma possui algumas limitações em relação à produtividade, à qualidade e à uniformidade no acabamento. Dentre tais limitações pode ser citada a necessidade de troca constante dos abrasivos do (s) cabeçote (s), o grande tempo de parada entre as cargas e descargas das chapas na bancada, a dependência da sensibilidade do operador para saber o momento ideal para trocar um abrasivo mais grosso por um mais fino e a grande possibilidade de um polimento não uniforme entre chapas de um mesmo material (KASCHNER, 1996).

A grande inovação referente ao polimento de placa de rocha ocorreu no final da década de 70. Com a invenção das politrizes multicabeças automáticas, ocorreu um aumento considerável na produção de placas polidas. Este equipamento é composto por um chassi de ferro fundido ou aço que assenta uma bancada ou mesa perfeitamente plana, sobre a qual corre uma esteira de borracha que transporta as chapas a serem polidas. Sobre esta esteira e disposta longitudinalmente a ela, é montada uma trave que sustenta os conjuntos moto-redutor e cabeçote e realiza um movimento transversal sobre a mesa. A conjugação do movimento da esteira que conduz as chapas, com o movimento de rotação dos cabeçotes e o movimento transversal da trave, proporciona todos os movimentos necessários à ação dos abrasivos no processo de polimento. Os abrasivos são colocados nos cabeçotes em seqüência, do grão maior para o menor, no sentido de movimentação das placas, de modo que ao sair no final da esteira o material esteja polido (KASCHNER, op. cit).

Os diversos modelos disponíveis no mercado oferecem configurações que vão de 8 a 20 cabeçotes por equipamento. Quanto maior o número de cabeçotes maior a produtividade para o determinado nível de qualidade do polimento (Figura 2.24). 


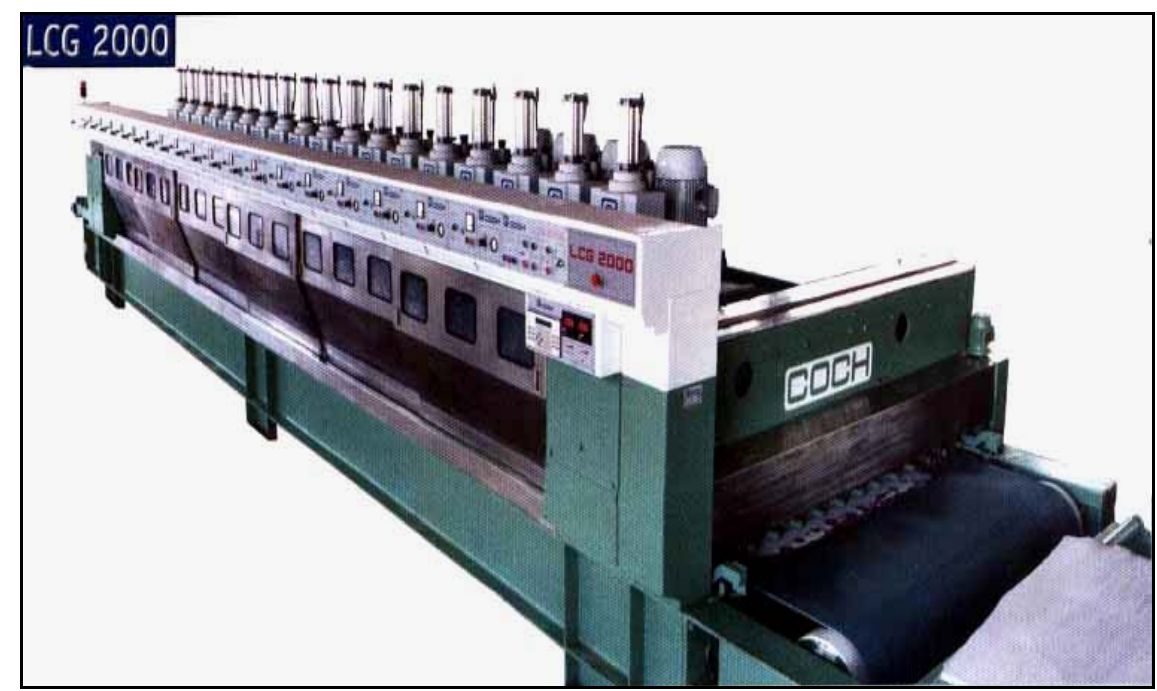

Figura 2.24 - Modelo de politriz automática multicabeças (CETEMAG, 2003).

O nível de automação é muito elevado e oferece facilidades operacionais como, programação das velocidades de esteira e trave, alarme indicando o fim dos rebolos abrasivos em cada cabeçote e abastecimento e desabastecimento automático sem o manuseio do operador (KASCHNER, 1996).

\subsection{CARACTERIZAÇÃO TECNOLÓGICA DE ROCHA PARA}

\section{ENGENHARIA}

A caracterização tecnológica tem como finalidades principais a de determinar quais são as propriedades e parâmetros que são importantes para a utilização do material para fins de engenharia e prever seu comportamento ao longo do tempo.

Godoy (2003) lembra que a crescente utilização de rochas ornamentais em obras civis tem despertado os usuários para os problemas decorrentes da escolha inadequada desses materiais. A melhor medida preventiva para minimizar estes problemas é a correta especificação das rochas frente ao uso pretendido observando-se, além do efeito estético desejado, as características tecnológicas dos materiais.

Muitos dos insucessos relatados na literatura sobre comportamento indesejado de rochas, ou de materiais pétreos em geral, usados na construção civil, poderiam ter sido 
evitados se tivesse havido um maior entendimento das propriedades destes materiais e um melhor entendimento de seu comportamento ante as diferentes solicitações em serviço (FRAZÃO, 2002).

Diante de tantas solicitações que o material rochoso necessita atender para esta ou aquela finalidade, uma grande quantidade de ensaios foi, e está sendo desenvolvida para simular tais solicitações e avaliar o comportamento das rochas frente a tais situações. A grande maioria destes ensaios encontra-se normatizada. As principais entidades normatizadoras que tratam de caracterização tecnológica de rocha são:

- ABNT - Associação Brasileira de Normas Técnicas;

- ASTM - American Society for Testing and Materials;

- DIN - Deutsch Institut fur Normung;

- AFNOR - Association Française de Normalization;

- AENOR - Asociación Española de Normalización;

- BSI - British Standard Institute;

- CEN - Comitê Europeu de Normatização.

\subsubsection{CARACTERIZAÇÃO TECNOLÓGICA DE ROCHAS ORNAMENTAIS}

\section{E DE REVESTIMENTO}

Em um mercado cada vez mais exigente, não é mais aceita a utilização dos materiais pétreos sem o real conhecimento de suas qualidades e limitações. A indústria cerâmica tem crescido nos últimos anos devido, principalmente, ao fato de que apresenta ao cliente final um produto, embora não-natural, completamente caracterizado no seu ponto de vista tecnológico.

Relativo a este assunto Fioreti (2003) diz que é mais fácil para profissionais de arquitetura especificar a cerâmica do que o granito, pois se tem, em geral, pouca informação disponível sobre os aspectos físicos da pedra, enquanto que na cerâmica, tem-se as 
especificações referentes à cor, dureza, porosidade, etc. A pedra, por ser um produto natural, a cada descoberta há um novo produto no mercado e se faz necessário um constante trabalho de levantamento e atualização dos dados.

As propriedades de uma rocha são influenciadas pela composição mineralógica, textura (tamanho do grão e forma), fabric (arranjo dos minerais e vazios) e o grau de alteração. Grandes variações nas propriedades mecânicas podem ser atribuídas a variações nas características petrográficas das rochas. As características petrográficas que influem no comportamento mecânico das rochas incluem tamanho e forma dos minerais, grau de imbricamento, tipos de contato e composição mineralógica (TUGRUL e ZARIF, 1999).

De modo geral, a resistência de uma rocha tende a diminuir à medida que o tamanho dos minerais aumenta, existindo uma relação linear inversa entre a granulação e a resistência (ONODERA e KUMARA, 1980).

Chiodi Filho (2002a) enfatiza que além das feições estéticas desejáveis para as rochas ornamentais e de revestimento, a seleção e o uso dos materiais deve levar em conta suas características tecnológicas. Tais características refletem, basicamente, o comportamento físico-mecânico das rochas nas condições normais de utilização, permitindo ainda diagnosticar problemas estéticos decorrentes da seleção e aplicação inadequada desses materiais. Os ensaios de caracterização tecnológica objetivam balizar os campos de aplicação dos materiais e seu comportamento frente às solicitações, sendo já exigidos pelos consumidores e constando como item obrigatório em catálogos fotográficos promocionais dos grandes fornecedores.

Os principais ensaios relacionados com a caracterização tecnológica de rocha para fins ornamentais são: análise petrográfica, índices físicos, desgaste Amsler, compressão uniaxial, resistência à tração na flexão e coeficiente de dilatação térmica linear, dentre outros. Tais ensaios serão pormenorizados a seguir: 


\subsubsection{ANÁLISE PETROGRÁFICA (ABNT NBR 12768)}

É realizada a partir do exame por microscopia óptica de luz transmitida em lâminas delgadas com espessuras na ordem de $30 \mu \mathrm{m}$. A petrografia de seções delgadas constitui o único método de investigação laboratorial que possibilita a visualização detalhada dos constituintes da rocha, permitindo avaliar as implicações de suas propriedades no comportamento posterior dos produtos aplicados.

Tugrul e Zarif (1999), estudando cerca de dezenove tipos de granitos turcos, correlacionaram algumas características petrográficas com propriedades mecânicas e físicas. As amostras passaram por uma descrição sumarizada de suas características petrográficas (tamanho médio dos grãos, forma, tipo de contato intergranular, e composição modal) e, das mesmas, foram obtidos os seguintes parâmetros: peso específico aparente seco, peso específico aparente saturado, absorção d'água, porosidade total e efetiva, velocidade das ondas $\mathrm{P}$, dureza de Schmidt, índice de resistência a carga pontual, resistência à compressão uniaxial, resistência à tração e módulo de elasticidade. Os principais resultados obtidos pelos autores são descritos a seguir:

- Correlação entre razão quartzo/feldspato e tamanho dos minerais - A porosidade é a proporção relativa de sólidos e vazios e o peso específico aparente seco dá informações sobre a mineralogia e os constituintes minerais (GOODMAN, 1989 apud TUGRUL e ZARIF, op. cit.). O conteúdo de quartzo tem uma grande influência nos valores de peso específico e porosidade, visto que, por ser o último a ser formar em rochas ígneas, muitas vezes preenche vazios preexistentes. O peso específico aparente seco é diretamente proporcional a razão quartzo/feldspato (Figura 2.25). 


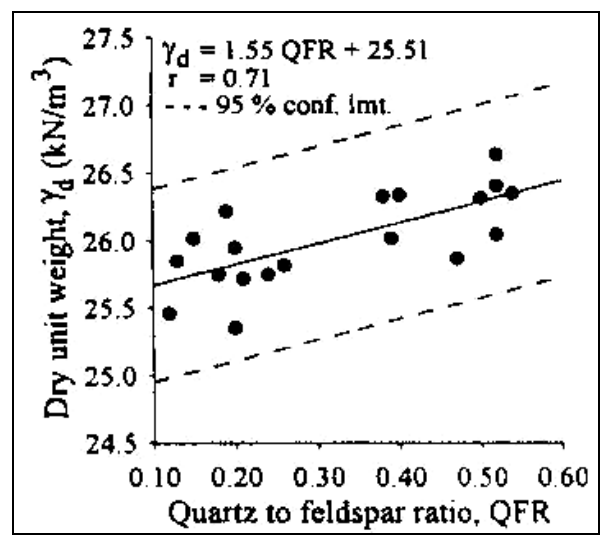

Figura 2.25 - Relação ente razão quartzo/feldspato e peso específico aparente seco (TUGRUL e ZARIF, 1999).

- Correlação entre razão quartzo/feldspato e resistência à compressão - De acordo com a Figura 2.26 existe uma relação linear entre tais variáveis. A presença de mineral com plano de clivagem e microfissuras nos feldspatos tende a diminuir a resistência à compressão.

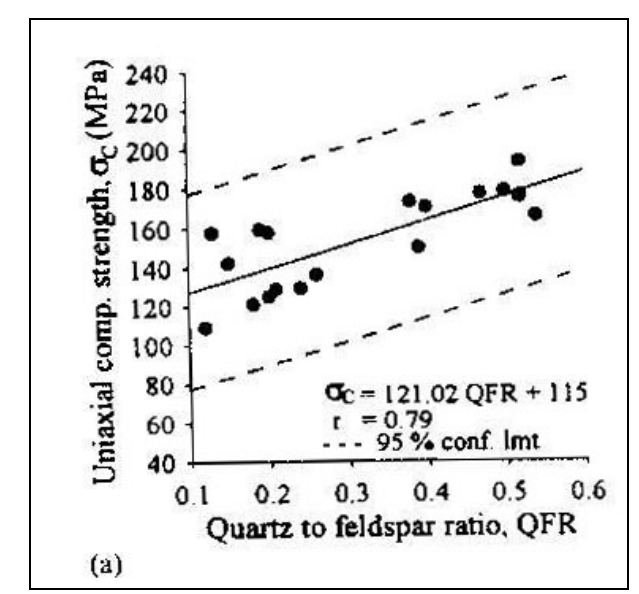

Figura 2.26 - Relação entre resistência à compressão e a razão quartzo/feldspato (TUGRUL e ZARIF, 1999).

- Correlação entre razão quartzo/feldspato e resistência à tração - A resistência à tração é controlada pelos mesmos fatores que condicionam a resistência à compressão, que são: composição, textura e granulação (Figura 2.27). 


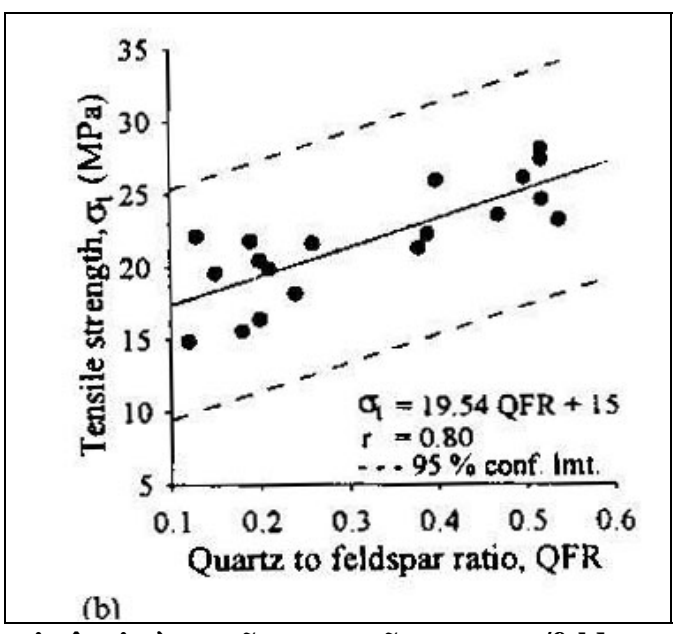

Figura 2.27 - Relação entre resistência à tração e a razão quartzo/feldspato (TUGRUL e ZARIF, 1999).

Como é possível notar na Figura 2.28 o feldspato apresenta um importante papel na diminuição da resistência.

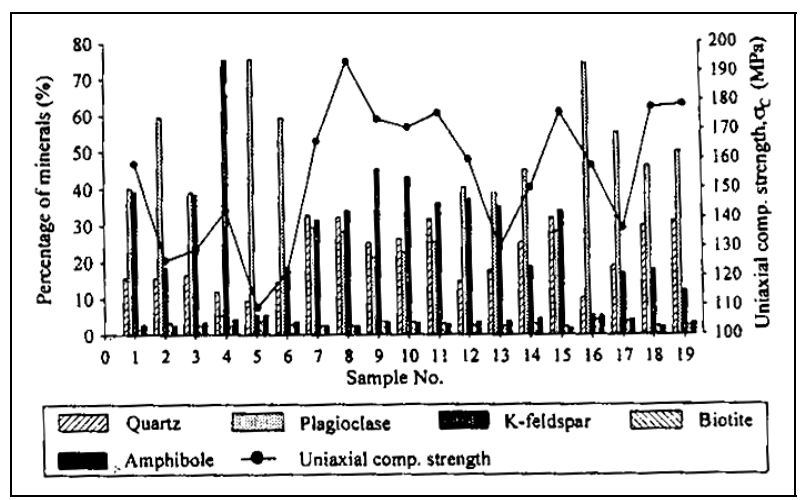

Figura 2.28 - Gráfico em barras mostrando a relação entre percentagens de minerais e a resistência à compressão (TUGRUL e ZARIF, 1999).

\section{- Correlação entre o tamanho máximo dos grãos e resistência à compressão uniaxial}

- Como é possível notar na Figura 2.29 o tamanho dos grãos é o principal condicionante da resistência à compressão uniaxial. Em granitos, quanto menor for o tamanho médio dos grãos maior será a resistência. O coeficiente de correlação entre a resistência à compressão uniaxial e o tamanho do feldspato potássico (mostrada na Figura 2.30) é o mais significante $(r=0,91)$ entre os minerais constituintes. 


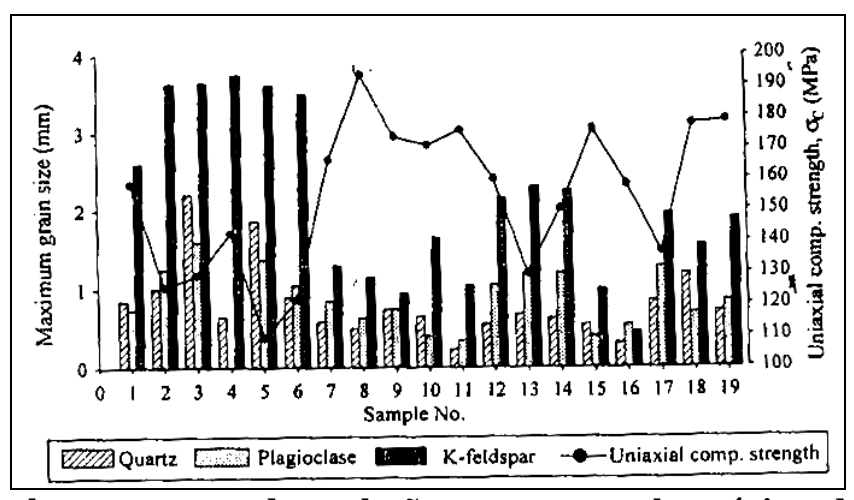

Figura 2.29 - Gráfico em barras mostrando a relação entre o tamanho máximo dos grãos e a resistência à compressão (TUGRUL e ZARIF, 1999).
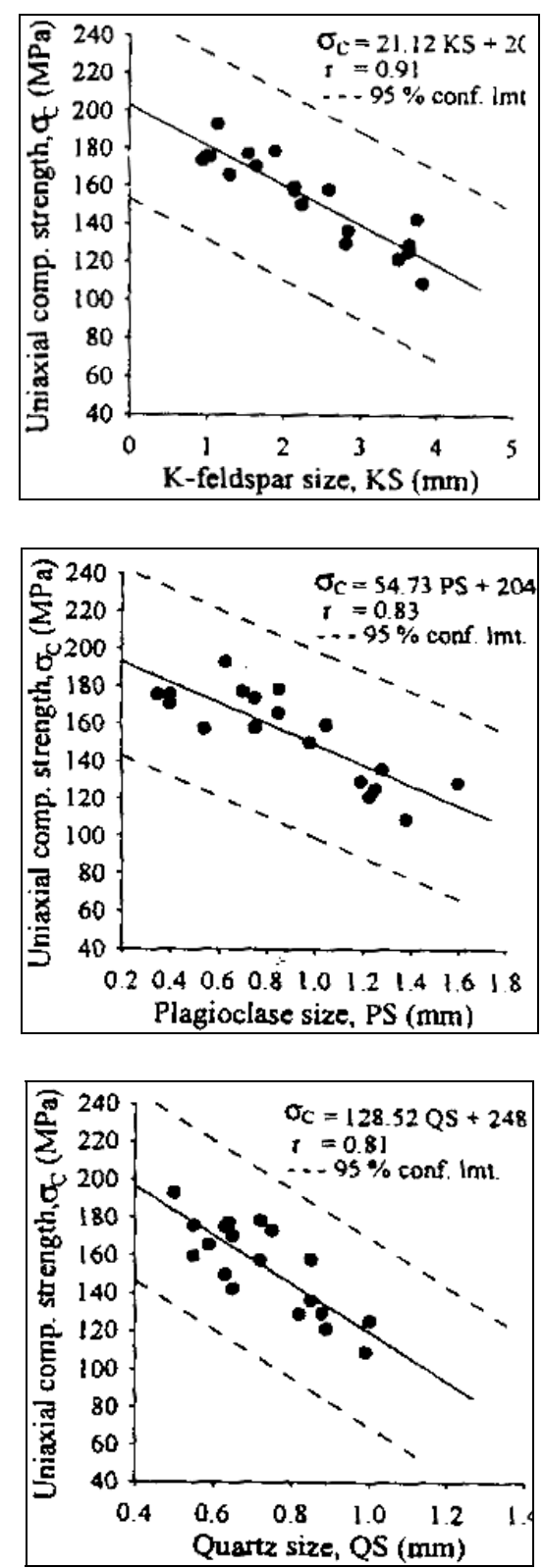

Figura 2.30 - Resistência à compressão uniaxial vs tamanho médio dos grãos: (a) Feldspato potássico, (b) Feldspato plagioclásio e (c) quartzo (TUGRUL e ZARIF, 1999). 
Frascá e Quitete (2000) utilizaram a análise petrográfica, juntamente com outras ferramentas, para justificar problemas ocorridos em uma placa de um monzogranito denominado comercialmente de granito Capão Bonito. Tal material apresentava cavidades superficiais, com 4 a $8 \mathrm{~mm}$ de diâmetro e $3 \mathrm{~mm}$ de profundidade, resultantes do desprendimento de fragmentos de minerais. Uma análise revelou intenso microfraturamento, tanto na superfície polida quanto no seu interior, e forte alteração de plagioclásio em argilominerais. A difração de raios X detectou a predominância de argilas do grupo da illita, com quantidades menores de esmictita e vermiculita, sendo concluído que a pressão de expansão das esmictitas, quando hidratadas, aliada ao intenso microfissuramento da rocha e à forte alteração do plagioclásio contribuíram expressivamente no desprendimento dos fragmentos minerais.

\subsubsection{2. ÍNDICES FÍSICOS (ABNT NBR 12766)}

No setor de rochas ornamentais, o termo índices físicos abrange ensaios que determinam as relações básicas entre massa e volume de determinado material. Os índices físicos são descritos a seguir:

- Massa específica e porosidade - Uma rocha no seu estado natural apresenta-se como um conjunto de minerais interligados ocupando um determinado volume, constituído pelos minerais e pelos vazios entre eles. A maior ou menor quantidade de vazios gera menor ou maior compacidade da rocha, que refletirá numa maior ou menor massa específica, por conseqüência, maior ou menor porosidade. Uma relação entre a massa dos minerais (M) e o volume real dos minerais $(\mathrm{Vr})$ define a massa específica real ou absoluta $\left(\rho_{\mathrm{r}}\right)$ :

$$
\rho_{r}=\frac{M}{V r}
$$


O índice de absorção d'água nunca é maior que o índice de porosidade aparente, destacando-se que uma rocha com alta porosidade não tem obrigatoriamente alta absorção d'água, pois seus poros e cavidades podem não ser comunicantes.

A massa específica aparente e a porosidade aparente fornecem indicações sobre a resistência físico-mecânica da rocha, mediante esforços compressivos e de flexão. O índice de absorção d'água, por sua vez indica a capacidade da rocha em ser encharcada por líquidos.

Frazão (2002) lembra que as propriedades da rocha são muito influenciadas pela absorção d'água. Rochas com alta absorção d'água apresentam aumento na massa específica aparente saturada e na condutividade térmica, dentre outras, enquanto que a resistência mecânica diminui, por enfraquecimento das ligações intergranulares. É recomendável, portanto, que os ensaios mecânicos sejam executados também no estado saturado. 


\section{MATERIAIS E MÉTODOS}

A Metodologia adotada é embasada em conceitos de Tribologia, cujo enfoque permite obter uma visão abrangente dos fenômenos que regem a interação entre os elementos responsáveis por um sistema de desgaste. A primeira fase, de levantamento bibliográfico, mostrou um farto compêndio de referências que tratava do tema, porém, sem considerar a rocha como o elemento a ser desgastado, mas sim materiais metálicos.

Foi possível observar que, apesar de não terem sido concebidos na área geotécnica, os conhecimentos dos mecanismos de desgaste, utilizados principalmente nas engenharias Mecânica e de Materiais, poderiam servir como base para uma melhor compreensão do polimento de rochas ornamentais.

Para a tentativa de utilização de tais conhecimentos em materiais pétreos optou-se pela escolha de seis rochas que ao mesmo tempo fossem materiais conhecidos no setor e apresentassem aspectos petrográficos, texturais e estruturais distintos, justamente para comparar os resultados obtidos e tentar relacionar quais variáveis da rocha que mais pesariam na iteração deste sistema. Os materiais escolhidos foram o gnaisse Preto indiano e o sienogranito Vermelho Brasília, o monzogranito Cinza Castelo, o migmatito Desert Storm, o charnoquito Verde Labrador e o sienogranito Vermelho Capão Bonito e serão descritos a seguir:

\subsection{MATERIAIS ROCHOSOS ESTUDADOS}

\subsubsection{VERMELHO BRASÍLIA}

Esta rocha é extraída no município de Jaupací, Estado de Goiás (Figura 3.1). Suas principais características petrográficas serão descritas a seguir: 


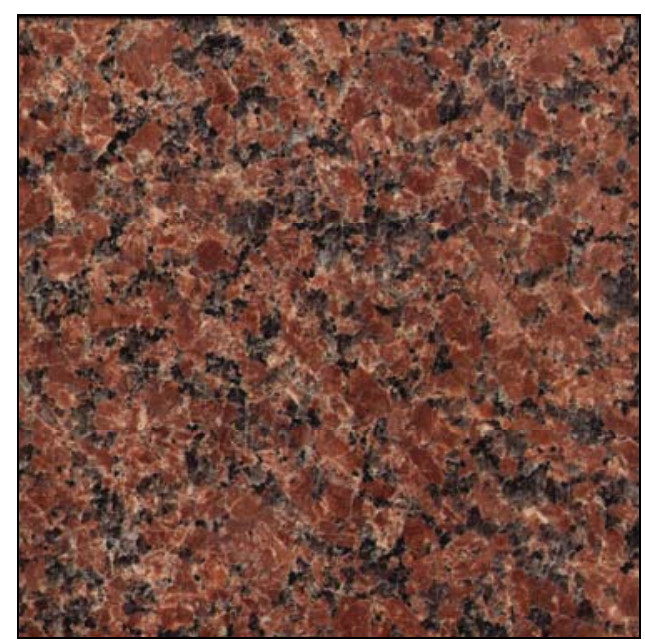

Figura 3.1 - Granito Vermelho Brasília.

\section{ANÁLISE PETROGRÁFICA}

Sigla Amostra: VB

Rocha: Sienogranito

Nome Comercial: Vermelho Brasília

\section{Descrição Macroscópica}

Rocha de coloração vermelha com estrutura discretamente orientada, inequigranular, de granulação grossa. A granulação oscila desde $0,3 \mathrm{~mm}$ até cerca de 5,0 $\mathrm{cm}$ ou mais, com predominância entre 0,5 e 3,0 cm, caracterizada por bom entrelaçamento mineral. Os cristais maiores são de microclínio, os quais exibem formas variadas, podendo ser irregulares, alongados ou ovalados (com dimensões que podem atingir até 2,5 $\times 5,0 \mathrm{~cm}$ ) a prismáticos (nestes casos apresentam dimensões que vão desde $0,5 \times 0,5 \times 1,5 \mathrm{~cm}$ a $1,5 \times 2,0 \times 5,0 \mathrm{~cm}$ ). Apresentam contornos irregulares (devido a corrosão durante cristalização magmática) e mais raramente retilíneos (situação mais freqüente nos cristais prismáticos), o que, apesar da granulação grossa da rocha, se reflete em bom imbricamento mineral e conseqüentemente na coesão da rocha.

Os cristais de quartzo constituem agregados com formas irregulares a predominantemente alongados, homogeneamente distribuídos pela rocha, que podem atingir 
até cerca de 3,0 $\mathrm{cm}$ ao longo do maior estiramento. Apresenta baixo grau de microfissuramento intragrãos e, localmente, intergrãos.

A discreta feição orientada exibida pela rocha é definida por certa isorientação, mais ou menos evidente, dos cristais prismáticos ou alongados de feldspato potássico. A disposição levemente orientada dos cristais de feldspato potássico resulta, provavelmente, de fluxo magmático; conclusão esta embasada na ausência de efeitos deformacionais tanto sobre a rocha quanto nos cristais de feldspato.

Destaca-se, também, o freqüente intercrescimento entre feldspato potássico e plagioclásio (observáveis mesmo macroscopicamente), sendo que em alguns casos o plagioclásio desenvolve semi-anéis ao redor do microclínio. Os cristais maiores de feldspato potássico apresentam moderado grau de microfissuramento, de âmbito intragrãos.

A biotita constitui, com certa freqüência, agregados de cristais lamelares (livretos), o que pode conduzir a descamamento das mesmas.

A face polida é praticamente paralela ao plano da (discreta) foliação da rocha, o que produz, a grosso modo, um leve aspecto amendoado para a referida superfície. Tal feição é resultante do corte dos cristais de feldspato potássico em planos paralelos aos seus maiores eixos cristalográficos. Nestas superfícies os cristais de microclínio expõem com maior nitidez seus planos de clivagem, o que se reflete em um maior grau de microfissuramento intragrãos quando comparadas com as faces tabulares dos referidos cristais presentes nas superfícies de corte perpendiculares à foliação de fluxo.

A superfície de corte perpendicular à foliação de fluxo, segundo maior estiramento mineral realça o fluxo magmático, o qual é evidenciado pelas faces tabulares alongadas (faces laterais) dos cristais prismáticos de microclínio grosseiramente alinhados. 


\section{Descrição Microscópica}

Composição Mineralógica
(\% modal contada:

macro e microscopicamente)

Quartzo: ...................................................................... 32,

Microclínio: ............................................................................. 41,0

Plagioclásio (oligoclásio) ....................................................... 16,0

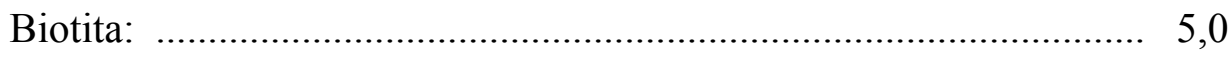

Acessórios: opacos, apatita, zircão, granada ……...................... 2, $\quad 2$

Minerais Secundários: sericita, muscovita, epidoto, clorita, carbonatos, argilo-minerais, hidróxidos de ferro …................. 4,0

Estrutura: Discreta orientação de fluxo, evidenciada basicamente por grosseira orientação preferencial dos cristais alongados de microclínio.

Textura: Microscopicamente exibe textura fanerítica média a grossa, inequigranular, hipidiomórfica. A granulação média oscila entre 0,5 a $1,5 \mathrm{~cm}$, sendo que o microclínio representa os cristais com as maiores dimensões. Os contatos minerais variam de interlobados (côncavo/convexos) a parcialmente retilíneos, refletindo, no geral, em bom entrelaçamento mineral. Registra-se que os contatos entre os agregados monominerálicos de quartzo e os cristais de feldspatos são irregulares, e que internamente aos referidos agregados os cristais de quartzo exibem entre si contatos preferencialmente retilíneos a levemente lobulados. Já os cristais de microclínio e de plagioclásio exibem contornos externos côncavo/convexos a irregulares, devido a freqüentes feições de corrosão magmática, o que contribui para o melhor imbricamento global da rocha (Figura 3.2). 
Estado Microfissural: Baixo microfissuramento, predominantemente intergranular, preferencialmente nos cristais de quartzo. As microfissuras mostram-se tanto fechadas quanto abertas, nestes casos, preenchidas por minerais opacos, sericita e algum epidoto.

Transformações minerais: Fraca a moderada alteração mineral caracterizada por visível argilomineralização dos cristais de feldspatos, manifestando-se sob forma de manchas pulverulentas, de coloração acastanhada devido ao efeito da pigmentação por óxidos e hidróxidos de ferro (Figura 3.3). Os cristais de plagioclásio são os mais afetados, principalmente em seus núcleos, além de exibirem discreto efeito de sericitização. Já nos cristais de microclínio, apesar de menos afetados, a argilomineralização distribui-se homogeneamente por toda a extensão de sua superfície (Figura 3.4). Os cristais maiores de biotita encontram-se praticamente inalterados, por vezes com discreta cloritização em bordas com texturas simplictíticas, além de conterem algumas micro-inclusões lineares de agregados de opacos disseminados dispostos ao longo dos planos de clivagem.

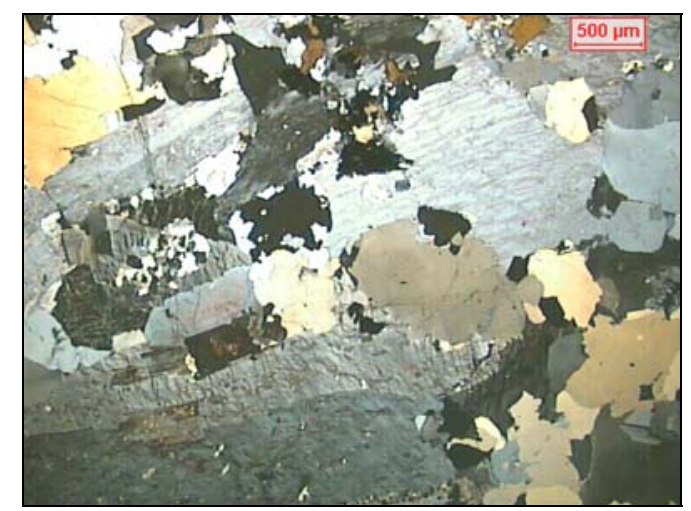

Figura 3.2 - Fotomicrografia com a visão geral das relações de contato entre os minerais (nicóis cruzados).

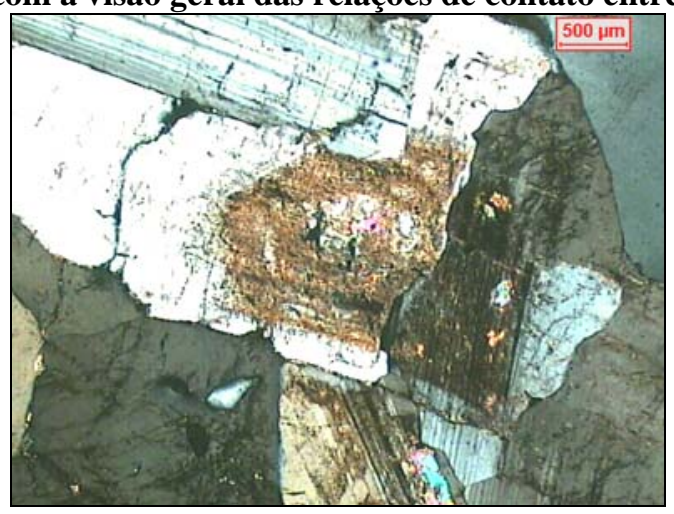

Figura 3.3 - Fotomicrografia mostrando plagioclásio pigmentado por óxidos e hidróxidos de ferro, evidenciando argilomineralização (nicóis cruzados). 


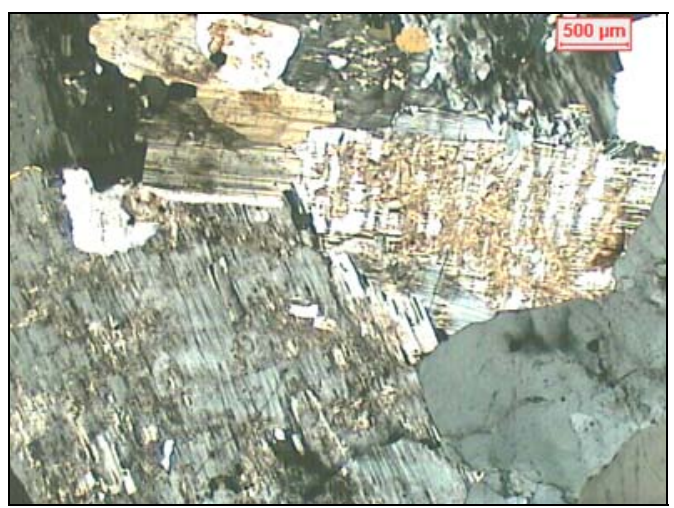

Figura 3.4 - Fotomicrografia contendo microclínio com argilomineralização em toda a sua superfície (nicóis cruzados).

\subsubsection{PRETO INDIANO}

Esta rocha é lavrada no município de Vargem Alta, próximo ao pólo industrial de Cachoeiro de Itapemirim, no Estado do Espírito Santo (Figura 3.5). São detalhadas a seguir, suas características petrográficas.

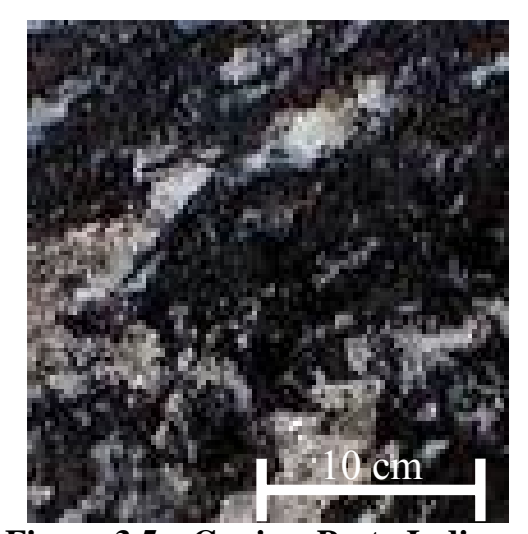

Figura 3.5 - Gnaisse Preto Indiano.

\section{ANÁLISE PETROGRÁFICA}

\section{Sigla Amostra: PI}

Rocha: Migmatito com estrutura dobrada e parcialmente gnaissificado (rocha movimentada)

Composição geral: Paleossoma tonalítico

\section{Leucossoma monzogranítica/granodiorítica}

Nome Comercial: Preto Indiano 


\section{Descrição Macroscópica}

Migmatito cinza escuro com estrutura dobrada, do tipo metatexítico, exibindo diferente intensidade de gnaissificação, responsável pelo maior ou menor grau de paralelismo entre os leitos paleossômicos e leucossômicos. A estrutura dobrada caracteriza-se pela presença de dobras normalmente fechadas a pouco abertas, com marcante adelgaçamento dos flancos e espessamento dos ápices, regiões estas com acúmulo de material leucossômico.

O paleossoma apresenta cor cinza escuro, composição tonalítica, constituído predominantemente por plagioclásio (andesina), quartzo e biotita, além de sillimanita, muscovita e menos freqüentemente granada, cordierita parcial a totalmente alterada para esmictita e opacos. Apresenta textura granolepidoblástica parcialmente recristalizada, de granulação média, predominantemente entre 1,5 e 4,0 $\mathrm{mm}$.

O leucossoma apresenta cor esbranquiçada, composição monzogranítica/granodiorítica, com estrutura orientada e textura fanerítica média $(2,0$ a 4,0mm) e com a presença de porções de granulação média/grossa $(5,0$ a 10,0mm). Localmente encontra-se parcialmente envolvida por delgados leitos descontínuos de melanossoma essencialmente biotítico contendo sillimanita e alguma muscovita.

A face polida corresponde a uma seção levemente oblíqua em relação aos planos de alternância entre os leitos paleossômicos e leucossômicos, situação esta que permite uma boa visualização da estrutura migmatítica, mais ou menos gnaissificada da rocha, realçando, desta forma, seu aspecto movimentado. Assim, as espessuras dos referidos leitos, bem como a dos filetes melanossômicos, são mais largos nas faces polidas, o que conduz a uma maior exposição das faces dos "livretos de biotita". 


\section{Descrição Microscópica}

\section{Composição Mineralógica}

(\% modal)

\section{$\underline{\text { Paleossoma }} \underline{\text { Leucossoma }}$}

Quartzo:

23,0 32,0

Microclínio:

4,5 25,0

Plagioclásio (andesina / oligoclásio) 42,0 40,0

Biotita: 21,0 3,0

Sillimanita 5,0

Muscovita 3,0
Granada

Cordierita parcialmente alterada $\mathrm{p} /$ esmictita $\ldots .$.

Opacos

0,2

Zircão

$\operatorname{Tr}$

$\operatorname{Tr}$

$\operatorname{Tr}$

$\operatorname{Tr}$

Argilo-minerais

1,0

0,3

2

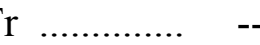

Sericita

Estrutura: Estrutura geral foliada evidenciada pela alternância entre leitos paleossômicos, leucossômicos e melanossômicos. Os microleitos enriquecidos em minerais máficos (biotita lamelar, acículas de sillimanita e muscovita) mostram-se fortemente foliados, seguidos pela marcante isorientação dos cristais alongados de feldspatos e de quartzo da fração paleossômica.

Textura: Paleossoma com textura granoblástica a granolepidoblástica, de granulação média a média/fina, e leucossoma fanerítico hipidiomórfico com granulação média a média/grossa. Os raros leitos melanossômicos apresentam texturas lepidoblásticas (Figura 3.6). Os contatos 
minerais são predominantemente côncavo-convexos, e apenas localmente retilíneos, principalmente relacionados a agregados melanossômicos ou em concentrações biotíticas e de acículas de sillimanita, produzindo, no geral, trama com bom engrenamento mineral.

Estado Microfissural: Baixo microfissuramento, predominantemente intragrãos, preferencialmente nos cristais maiores de feldspatos e de quartzo da porção leucossômica (Figura 3.7). As microfissuras são de pequena extensão e normalmente preenchidas por sericita e muscovita. Já as acículas de sillimanita são fortemente fraturadas, mas de caráter bastante localizado.

Transformações minerais: Fraca alteração mineral. A alteração mineral relaciona-se principalmente aos cristais de sillimanita, a alguns cristais de plagioclásio e à cordierita. Esta última volumetricamente inexpressiva altera-se quase que totalmente para argilo-mineral (esmictita). A sillimanita transforma-se desde parcial a totalmente para finos agregados filossilicáticos, às vezes com intenso efeito de muscovitização. Alguns cristais de plagioclásio, tanto da fração paleossômica quanto da leucossômica, encontram-se de parcial a totalmente saussuritizados (Figura 3.8).

Nota: O migmatito ora analisado é produto de metamorfismo sobre metassedimentos aluminosos, enriquecidos em ferro. Corresponde, provavelmente, a um xisto quartzofeldspático (rico em ferro) migmatizado.

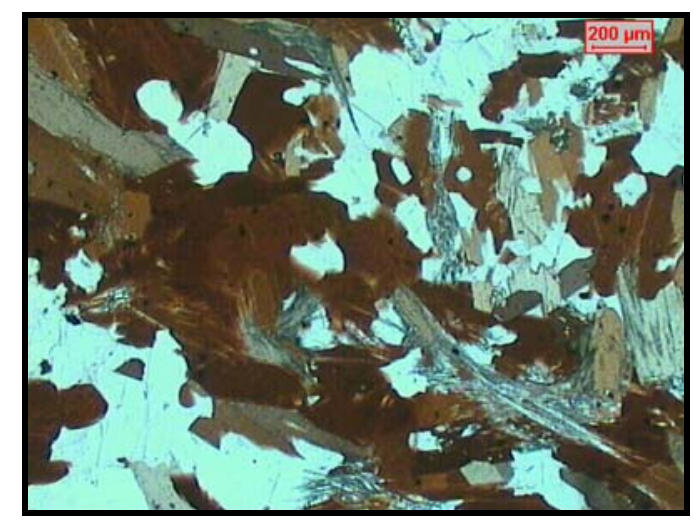

Figura 3.6 - Fotomicrografia evidenciando faixa de concentração de biotita separadas por porções granulares, o que define uma textura granolepidoblástica (nicóis paralelos). 


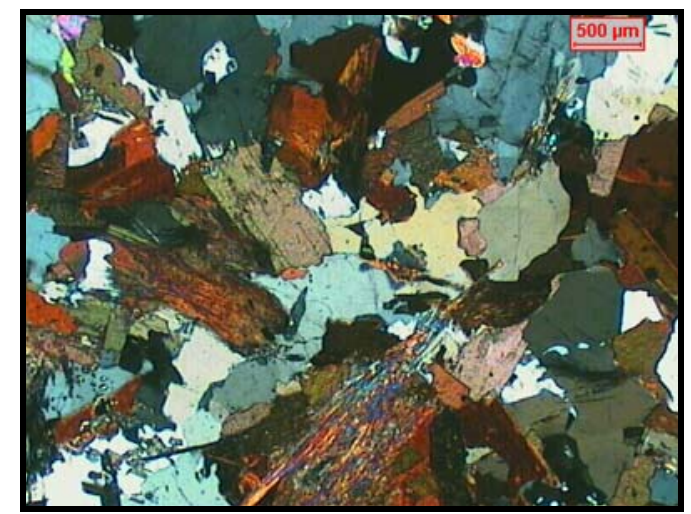

Figura 3.7 -Fotomicrografia da porção leucossômica mostrando pequeno grau de microfissuramento, principalmente nos cristais de quartzo (nicóis cruzados).

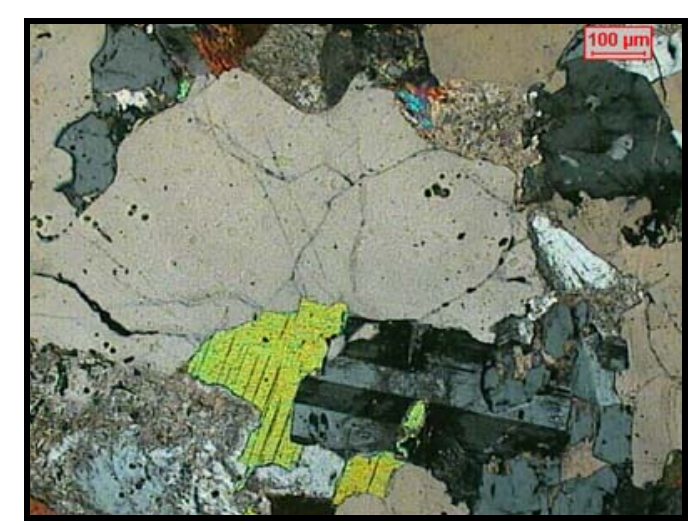

Figura 3.8 - Fotomicrografia de cristais de feldspato plagioclásio com diferentes graus de saussuritização (nicóis cruzados).

\subsubsection{CINZA CASTELO}

O monzogranito Cinza Castelo é lavrado nas proximidades do município de Castelo, localizado na porção sul do Estado do Espírito Santo (Figura 3.9). A descrição petrográfica pode ser vista a seguir. 


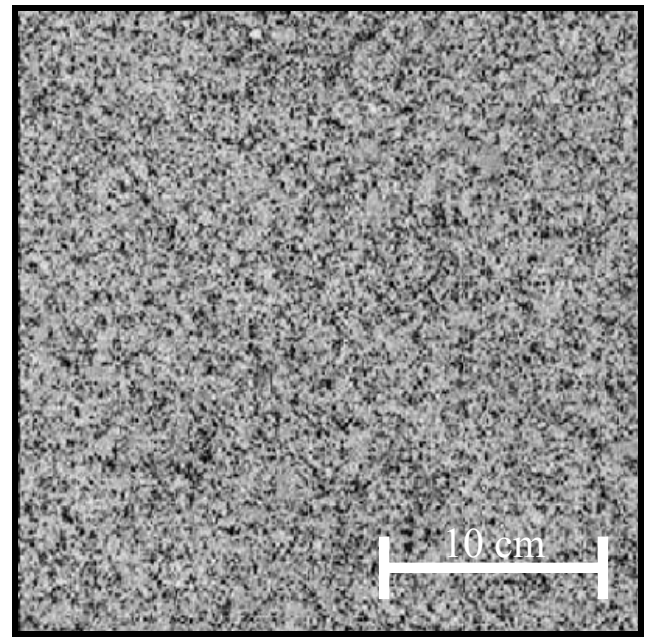

Figura 3.9 - Granito Cinza Castelo.

\section{ANÁLISE PETROGRÁFICA}

Sigla Amostra: CC

Rocha: Monzogranito

Nome Comercial: Cinza Castelo

\section{Descrição Macroscópica}

Rocha de coloração cinza claro, com estrutura maciça e textura equigranular a levemente inequigranular, de granulação média tendendo a fina, e de aspecto geral bastante homogêneo. A granulação varia de submilimétrica a no máximo 5,0mm, com predominância entre 1,0 e $2,5 \mathrm{~mm}$. A biotita perfaz cerca de $7 \%$ a $8 \%$ da rocha e ocorre essencialmente sob forma de pequenas lamelas, com dimensões essencialmente submilimétricas a milimétricas, homogeneamente distribuída pela rocha.

Os cristais maiores estão representados por feldspatos de coloração rósea claro. O quartzo ocorre tanto sob forma de cristais isolados, com dimensões normalmente inferiores a $1,5 \mathrm{~mm}$, com formas irregulares a arredondados, quanto intersticialmente.

Apesar do aspecto geral homogêneo e isotrópico exibido pela face polida, apresenta, localmente, discretos sinais de fluxo magmático, evidenciado por sutil alinhamento de cristais de quartzo pouco alongados e por pequenos cordões descontínuos de lamelas de biotita. Estes 
locais definem feições planares difusas, descontínuas, com disposição perpendicular ou oblíqua em relação à face polida da rocha.

\section{Descrição Microscópica}

\section{Composição Mineralógica}

Quartzo: 29,0

Microclínio: 34,0

Plagioclásio (oligoclásio) 22,5

Biotita: 8,0

Acessórios: opacos $(0,6 \%)$, titanita $(0,7 \%)$, allanita $(0,3 \%)$, apatita $(0,2 \%)$, zircão e fluorita 2,0

Minerais Secundários: sericita (2,5\%), muscovita (1,0\%), clorita (0,5\%), epidoto, carbonatos, argilo-minerais 4,5

Estrutura: Microscopicamente, apresenta estrutura tipicamente isotrópica, compacta.

Textura: Fanerítica média a média/fina, equigranular, hipidiomórfica, com granulação predominantemente entre 1,0 e 2,5mm. Os contatos minerais são dos tipos côncavo/convexos, por vezes denteados, e localmente retilíneos, casos estes comuns nos poucos agregados de cristais de quartzo, produzindo, no geral, um excelente engrenamento mineral.

Estado Microfissural: Baixo microfissuramento, predominantemente intragrãos, preferencialmente nos cristais maiores de feldspatos (transversais à maior elongação mineral) e, por vezes, nos cristais de quartzo. As microfissuras são de pequena extensão e normalmente preenchidas por sericita e muscovita (Figura 3.10). 
Transformações minerais: Fraca alteração mineral, praticamente restrita aos cristais de plagioclásio e a algumas lamelas de biotita. Nos cristais de plagioclásio concentram-se essencialmente nas suas porções centrais, caracterizadas por marcante saussuritização (Figura 3.11), com a produção de sericita, microcristais de epidoto, algum carbonato e geração de cristais de muscovita com dimensões que podem superar a 1,0mm. Por vezes estes produtos de alteração percolam microfissuras, preenchendo-as, chegando a precipitar nas interfaces dos minerais vizinhos. Efeitos de argilização dos feldspatos são bastante raros. As biotitas se apresentam, por vezes, parcial a totalmente cloritizadas.

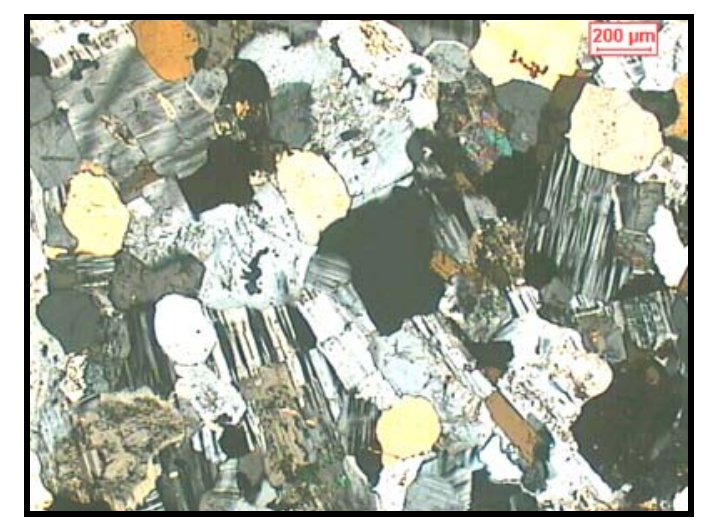

Figura 3.10 - Fotomicrografia de textura fanerítica média a média/fina, com cristais apresentando baixo grau de microfissuramento (nicóis cruzados).

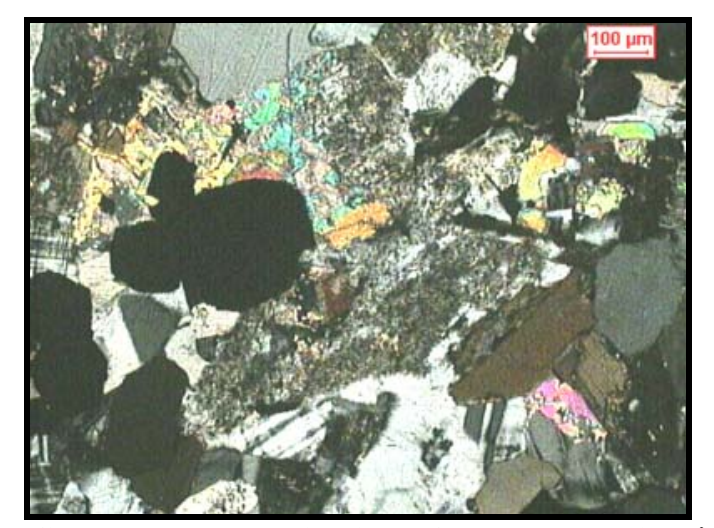

Figura 3.11 - Fotomicrografia apresentado cristais de feldspato plagioclásio em diferentes graus de saussuritização (nicóis cruzados). 


\subsubsection{DESERT STORM}

O migmatito Desert Storm é lavrado no distrito de Paulista, município de Barra de São Francisco, norte do Estado do Espírito Santo (Figura 3.12).

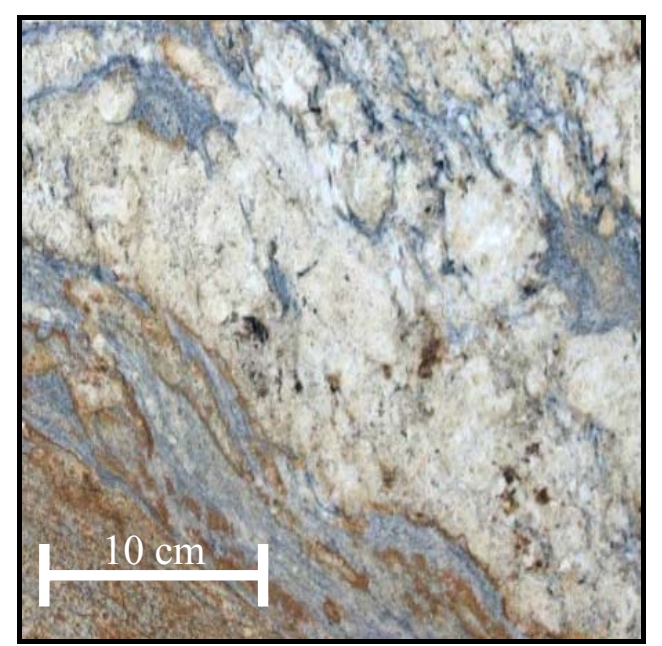

Figura 3.12 - Migmatito Desert Storm.

\section{ANÁLISE PETROGRÁFICA}

Sigla Amostra: DS

Rocha: Migmatito nebulítico gnaissificado róseo amarelado (Granito Pegmatóide Gnaissificado)

Nome Comercial: Desert Storm

\section{Descrição Macroscópica}

Rocha quartzo-feldspática pegmatóide grosseiramente gnaissificada (migmatito nebulítico pegmatóide gnaissificado) róseo claro a discretamente amarelado, devido a evidentes sinais de oxidação e de aspecto geral movimentado. Trata-se de rocha com estrutura e textura bastante heterogênea, caracterizada pela interação entre uma massa (arcabouço) quartzo-feldspática de granulação média a grossa (dimensões dos cristais oscilando de cerca de 5,0 $\mathrm{mm}$ a mais ou menos 1,5 cm) contendo: - leitos/bandas e bolsões alongados a lenticulares pegmatóides; - porções graníticas equigranulares, de granulação média; - difusas faixas gnáissicas mesossômicas descontínuas; - além da presença de veios feldspáticos. No 
conjunto, a heterogeneidade composicional/textural imprime uma feição geral bandada e localmente dobrada, caracterizando um padrão estético movimentado.

Os leitos e/ou bolsões pegmatóides são quartzo-feldspáticos, com ampla predominância de microclínio, podendo conter agregados (livretos) de biotita com dimensões que podem ultrapassar a $1,0 \mathrm{~cm}$ e por vezes marcada por evidentes sinais de oxidação. Estes leitos ou bolsões pegmatóides apresentam granulação variável, desde sub-centimétrica a cerca de 3 a $4 \mathrm{~cm}$, que podem exibir contatos bruscos ou difusos com a massa quartzo-feldspática (granítica) do arcabouço da rocha, ou ainda delineados lateralmente por delgadas faixas de material mesossômico de aspecto schiliericos.

As porções mesossômicas são pouco freqüentes e representam faixas difusas, irregulares e descontínuas, normalmente situadas nos contatos das frações pegmatóides. Apresentam leucossomas de aspectos nebulíticos a schiliericos, de coloração branco acinzentada, constituídos por plagioclásio, microclínio, quartzo e certo teor de biotita, contendo freqüentes microleitos melanossômicos biotíticos. Os cristais de biotita do leucossoma e principalmente das concentrações do melanossoma encontram-se relativamente oxidados, inclusive com evidentes percolações dos respectivos óxidos e hidróxidos de ferro ao longo de fraturas e microfissuras dos minerais vizinhos, responsáveis, em parte, pelo aspecto amarelado exibido pela rocha.

Os veios feldspáticos apresentam espessuras de poucos centímetros, são mais ou menos persistentes, irregularmente distribuídos e apresentam bordas irregulares e contatos normalmente difusos. Apresentam granulação variável, mas normalmente fina a média/fina. No geral encontram-se ligeiramente concordantes com a foliação geral da rocha, podendo localmente mostrar-se ondulados e mesmo com feições ptigmáticas.

A rocha exibe alguns planos descontínuos de microfalhas que ocasionam discretos deslocamentos transversais das estruturas da rocha. Também cabe destacar a presença dos 
planos melanossômicos, definidos pelas concentrações lineares de cristais de biotita, que representam descontinuidades físicas e que podem diminuir a resistência mecânica das chapas. Já o grau geral do microfissuramento da rocha, perceptível à vista desarmada, é baixo.

\section{Composição Mineralógica}

Obs.: Devido a heterogeneidade composicional e textural da rocha, a composição modal foi estimada através da combinação da visualização macroscópica das fotos das chapas e microscópica de seções delgadas e apresentada por faixa percentual.

\section{Mineralogia}

Quartzo:

Feldspato potássico (microclínio):

Plagioclásio (oligoclásio)

Biotita:

Acessórios: opacos, sillimanita, granada, apatita e zircão

Minerais Secundários: sericita, muscovita, epidoto, clorita, carbonatos, argilo-minerais, óxidos/hidróxidos de ferro
(\% modal)

$28,0-32,0$

$30,0-34,0$

$26,0-30,0$

$3,0-5,0$

2,5

$<3,5$

\section{Descrição Microscópica}

Obs.: A descrição microscópica foi embasada em seções delgadas confeccionadas a partir das porções quartzo-feldspáticas da massa predominante e de porções gnáissica mesossômicas.

Estrutura: Microscopicamente exibe estrutura foliada, com intensidade variável, ou seja, mais evidente nas porções mesossômicas. Nestes últimos casos exibem discreta alternância entre leitos quartzo-feldspáticos e delgados filetes enriquecidos em sillimanita, biotita e granada de granulação mais fina. 
Textura: Textura granoblástica média a média/grossa, inequigranular. As porções quartzofeldspáticas (de composição granítica) apresentam granulação média a grossa (pegmatóide), sendo que os cristais superam as dimensões de visualização do campo microscópico. Já as porções/leitos mesossômicos apresentam granulação média, oscilando entre submilimétrica a cerca de 5,0 a 6,0 mm, com predominância entre 1,0 e 3,0 mm.

Estado Microfissural: Moderado a elevado microfissuramento, que apesar da predominância do tipo intergranular também apresenta certo teor de microfissuras intergrãos. Os cristais maiores de quartzo e de feldspato potássico são os que exibem os maiores teores de microfissuramentos, tanto fissuras fechadas quanto abertas, nestes casos preenchidos por sericita, epidoto e por vezes contendo carbonatos e opacos disseminados. Muitas das microfissuras preenchidas mostram-se coloridas por hidróxidos de ferro, imprimindo coloração e/ou manchas vermelho alaranjadas.

Transformações minerais: A alteração mineral é relativamente expressiva, principalmente concentrada sobre os cristais de plagioclásio, os quais apresentam intensidade moderada a intensa em termos de saussuritização, inclusive podendo estar muscovitizado, e por vezes, produto de argilo-mineralização. Já no feldspato potássico, a sericitização e argilização se manifestam nos cristais com as maiores dimensões, mas com intensidade bastante inferior ao do plagioclásio. Os produtos da argilização imprimem, em nível microscópico, um aspecto pulverulento de coloração acastanhada sobre os cristais de feldspato, coloração esta resultante da pigmentação dos óxidos e hidróxidos que percolam a rocha.

Os cristais de feldspato potássico (microclínio) apresentam discreta geminação em grade e geralmente são mesopertíticos. Alguns cristais apresentam pertitização dos tipos filmes e, localmente, veios. Os cristais maiores apresentam ainda geminação Carlsbad e contém inclusões de minúsculos cristais de plagioclásio saussuritizados, grãos arredondados de quartzo e alguma biotita. 
O plagioclásio está representado essencialmente pelo oligoclásio, e apresenta formas, dimensões e intensidades variáveis em função da faixa analisada. Trata-se de mineral relativamente freqüente nas faixas mesossômicas, ocasiões em que apresenta formas subédricas a irregulares, pequenas dimensões e com menores intensidades de saussuritização. Nas porções pegmatóides são raros, e apresentam maiores dimensões e mais intensamente saussuritizados e argilizados.

O quartzo também apresenta teores, formas e dimensões que variam em função das porções ou faixas analisadas. Nas porções pegmatóides ou de natureza granítica são mais freqüentes e apresentam dimensões maiores, formas alongadas a estiradas e normalmente mais microfissurados que os cristais que ocorrem nas mesossômicas.

A biotita é rara nas porções pegmatóides e de natureza granítica, sendo relativamente comum nas faixas mesossômicas e básica nas microlentes/microleitos melanossômicos onde representam os minerais essenciais. No geral, os cristais de biotita encontram-se isentos de cloritizações, podendo, entretanto, exibir trilhas de minerais opacos ao longo dos planos de clivagens.

A sillimanita é bastante freqüente nas faixas mesossômicas, estando praticamente ausente nas demais porções da rocha. Nestas faixas constituem delgadas concentrações lineares, descontínuas, formadas por cristais prismáticos/aciculares submilimétricos, onde podem representar até cerca de $10 \%$ dos minerais desses microleitos.

A muscovita é rara e ocorre essencialmente como subproduto da saussuritização de alguns cristais de plagioclásio.

A granada também é bastante rara e ocorre sob forma de minúsculos cristais essencialmente ao longo das faixas mesossômicas. Igualmente os opacos são pouco comuns e 
ocorrem preferencialmente associados aos cristais de biotita das porções mesossômicas. Os demais minerais acessórios ocorrem na qualidade de traços.

\subsubsection{VERDE LABRADOR}

Rocha com procedência do Córrego Caciporé, entre os municípios de Vila Pavão e Barra de São Francisco, Estado do Espírito Santo (Figura 3.13).

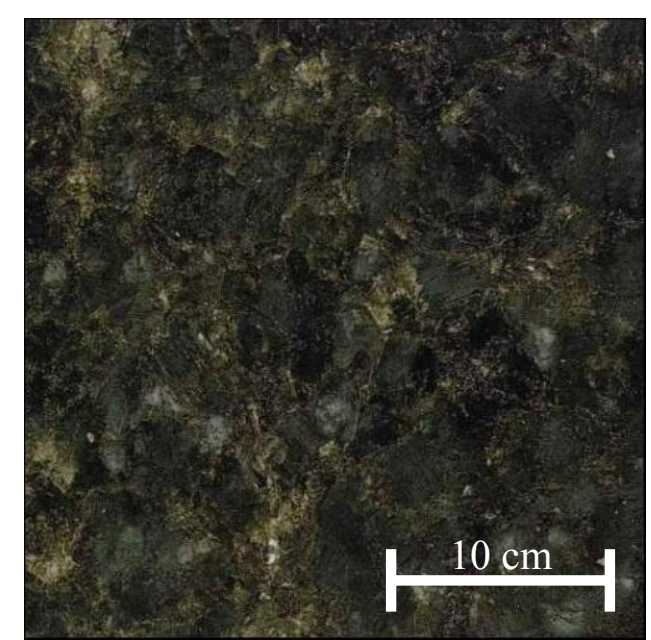

Figura 3.13 - Charnoquito Verde Labrador.

\section{ANÁLISE PETROGRÁFICA}

Sigla Amostra: VL

Rocha: Monzogranito

Nome Comercial: Verde Labrador

Designação: Charnoquito

\section{Descrição Macroscópica}

Rocha com estrutura isotrópica, compacta, de textura megaporfirítica serial com matriz inequigranular média a grossa. O feldspato potássico constitui cristais desde prismáticos a arredondados/ovalados com contornos retos a irregulares e dimensões oscilando ente cerca de 
1,0 a 4,5cm, imersos em matriz quartzo-feldspática com granulação média entre 0,4 e 1,5cm. O plagioclásio apresenta coloração esbranquiçada e dimensões bastante variadas, desde milimétrica até cerca de 2,5cm ao longo do maior eixo. O quartzo ocorre predominantemente sob a forma de agregados de grãos anédricos, responsável pela matriz que envolve os cristais de feldspatos. Os agregados de quartzo apresentam formas irregulares, alongadas e lenticulares, interligados entre si, e homogeneamente distribuídos pela rocha.

\section{Composição Mineralógica}

(\% modal contada)

Quartzo 32,0

Feldspato Potássico (ortoclásio mesopertítico) 40,0

Plagioclásio (oligoclásio) 17,0

Hiperstênio 3,0

Diopsídio

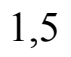

Granada 2,5

Acessórios: biotita, opacos, apatita, zircão e espinélio verde 1,5

Secundários: sericita/muscovita, epidoto, carbonatos, clorita, argilominerais e hidróxidos de ferro

Estrutura: isotrópica, maciça.

Textura: megaporfirítica serial com matriz fanerítica inequigranular de granulação média a grossa, interlobada. Contatos minerais côncavo/convexos a parcialmente retilíneos, refletindo, no geral, um bom entrelaçamento mineral. Ocorre a presença de megacristais de feldspato potássico com dimensões seriadas, desde as dimensões da granulação da matriz a cerca de $4,5 \mathrm{~cm}$ (neste caso observado microscopicamente) (Figura 3.14), em matriz oscilando de milimétrica (piroxênios e acessórios) a 1,5cm, com predominância ao redor de $1,0 \mathrm{~cm}$. 
Estado Microfissural: moderado microfissuramento, tanto intragranular quanto intergranular, principalmente em cristais piroxênios e de plagioclásio, com preenchimentos basicamente por fina massa filossilicática, além de algum epidoto, clorita, carbonatos e hidróxidos de ferro (Figura 3.15).

Transformações minerais: Incipiente alteração mineral, praticamente restrita ao hiperstênio que se encontra discretamente transformado para biotita verde e alguns minerais fibrosos com liberação de óxidos/hidróxidos de ferro.

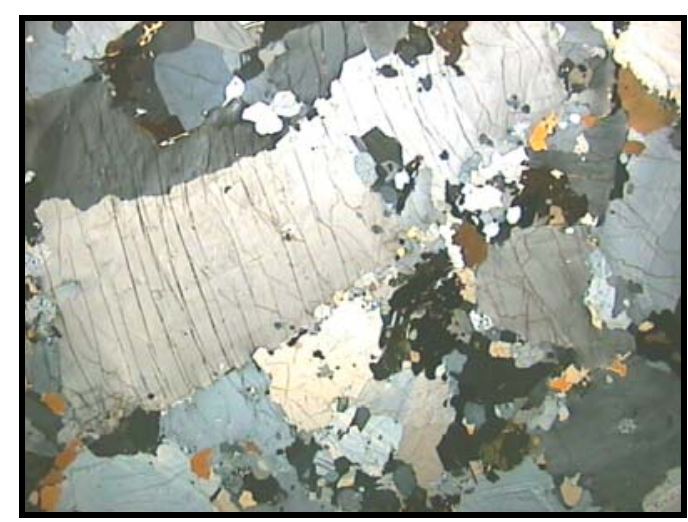

Figura 3.14 - Fotomicrografia de megacristal de feldspato potássico com intenso grau de microfissuramento intragrão (nicóis cruzados).

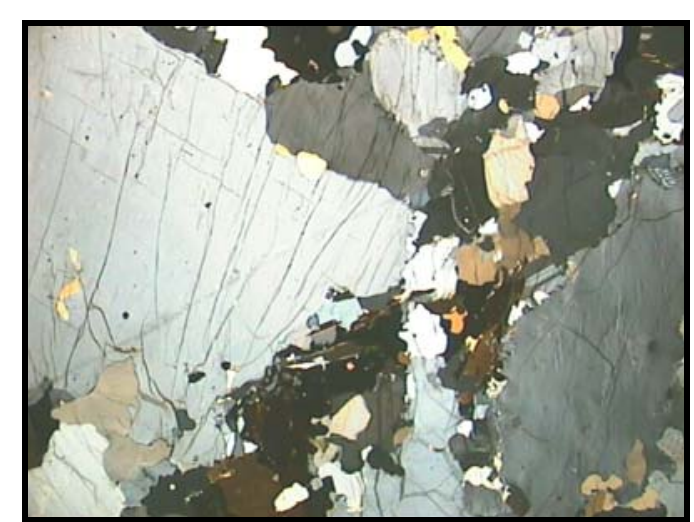

Figura 3.15 - Fotomicrografia de microfissuramento, intragranular e intergranular, verificado num cristal de feldspato potássico (nicóis cruzados). 


\subsubsection{VERMELHO CAPÃO BONITO}

Esta rocha é encontrada na região de Capão Bonito, localizado no Estado de São Paulo (Figura 3.16). As suas características petrográficas são descritas a seguir.

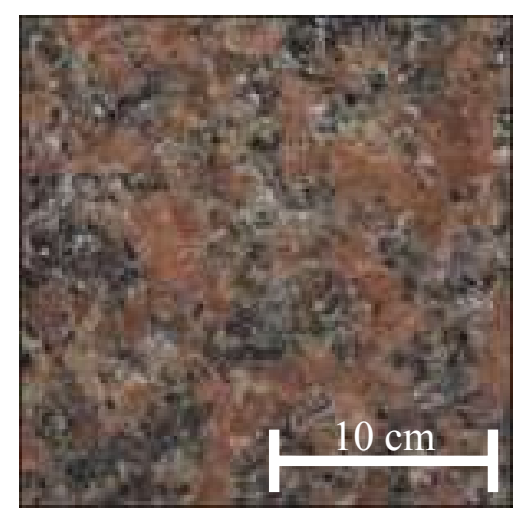

Figura 3.16 - Granito Vermelho Capão Bonito.

\section{ANÁLISE PETROGRÁFICA}

Sigla Amostra: CB

Rocha: Sienogranito

Nome Comercial: Vermelho Capão Bonito

\section{Descrição Macroscópica}

Rocha de coloração vermelha com estrutura maciça, marcadamente inequigranular, de granulação média a grossa tendendo a megaporfirítica. A granulação oscila desde $0,2 \mathrm{~cm}$ até cerca de $3,5 \mathrm{~cm}$, predominantemente entre 0,5 e $1,0 \mathrm{~cm}$. Os cristais com as maiores dimensões estão representados pelo microclínio, os quais apresentam formas variadas, podendo ser quadráticos (com seções basais que podem atingir até $1,0 \times 1,0 \mathrm{~cm})$, irregulares ou prismáticos alongados (com dimensões que vão desde $0,3 \times 0,3 \times 1,5 \mathrm{~cm}$ a cerca de $1,0 \times 1,0 \times 3,5 \mathrm{~cm}$ ) e invariavelmente caracterizados por contornos (formas externas) nitidamente irregulares, resultando em um excelente imbricamento mineral. Visualmente, os cristais maiores de microclínio exibem baixo microfissuramento intragrão, cujos planos mostram-se normalmente coincidentes com os respectivos sistemas de clivagem e com os planos de pertitização. 
No geral, o granito exibe textura tipicamente hipidiomórfica, caracterizada pela presença de cristais de plagioclásio subédricos. O plagioclásio constitui cerca de $16,0 \%$ do volume da rocha e forma cristais prismáticos com dimensões médias entre 3,0 e 4,0mm, podendo, entretanto, atingir até cerca de $1,0 \mathrm{~cm}$ ao longo do seu maior eixo.

O quartzo ocorre predominantemente sob a forma de agregados de grãos anédricos, responsável pela matriz que envolve os cristais de microclínio e de plagioclásio. Os agregados de quartzo apresentam formas irregulares, alongadas e lenticulares, interligadas entre si, e homogeneamente distribuídos pela rocha. Os cristais de quartzo apresentam dimensões médias ao redor de 3,0 a 4,0 mm, podendo atingir até cerca de 1,0 cm. Macroscopicamente apresentam baixo a moderado grau de microfissuramento intragrãos e, localmente, intergrãos.

O teor de minerais máficos é pouco expressivo (cerca de 5 a 6\%) os quais encontramse basicamente representados por delgados livretos de biotita.

\section{Composição Mineralógica}

Quartzo:

Microclínio:

Plagioclásio (oligoclásio)

Biotita:

Acessórios: opacos, apatita, zircão, titanita e fluorita

Minerais Secundários: sericita, muscovita, epidoto, clorita, carbonatos, argilo-minerais, óxidos de ferro
(\% modal contada)

34,5

40,5

6,0

1,5

2,0

Os cristais de microclínio de cor vermelha são os responsáveis pela coloração geral vermelha do granito. Apresentam nítida geminação em grade e fortemente pertitizados, com pertitas dos tipos filmes, veios e manchas. Os cristais maiores apresentam ainda geminação 
Carlsbad e contém inclusões de minúsculos cristais de plagioclásio saussuritizados, grãos arredondados de quartzo e alguma biotita.

O plagioclásio está representado pelo oligoclásio, com formas subédricas a irregulares, normalmente zonados, com núcleos mais cálcicos e caracterizados pela evidente saussuritização.

O quartzo forma cristais anedrais, com contornos irregulares, apresentando contatos lobulados a parcialmente planares. Exibe bom engrenamento com cristais de microclínio, e lobulados a planares nos agregados quartzosos monominerálicos. Apresentam extinção ondulante e baixo grau de microfissuramento intragrãos.

A biotita ocorre tanto sob a forma de lamelas isoladas quanto constituindo pequenos agregados irregularmente distribuídos pela lâmina. Apresentam forte desestabilização com liberação de óxido de ferro evidenciada pela existência de opacos disseminados e concentrados ao longo dos planos de clivagem. Localmente libera também titânio, chegando a desenvolver agregados lineares de minúsculos cristais de titanita secundária no seu interior. Mostram-se fracamente cloritizadas e, por vezes, com discreta muscovitização.

A fluorita é rara e ocorre sob forma de pequenos cristais e/ou agregados intersticiais ou nas interfaces minerais.

Estrutura: Isotrópica, localmente com discretas evidências de estrutura de fluxo, marcada por sutil orientação preferencial dos agregados lenticulares de quartzo.

Textura: Microscopicamente exibe textura fanerítica média a grossa, inequigranular, hipidiomórfica. Os contatos minerais variam de interlobados (côncavo/convexos) a parcialmente retilíneos, refletindo, no geral, em bom entrelaçamento mineral. Os contatos entre o microclínio e os cristais de quartzo se dão predominantemente por interpenetração, do tipo irregular, resultante da corrosão magmática do microclínio com preenchimento e 
cristalização dos cristais de quartzo. Já os contatos entre os grãos de quartzo dos respectivos agregados monominerálicos são de interlobulados a parcialmente planares.

Estado Microfissural: Baixo microfissuramento mineral, predominantemente intergranular, preferencialmente nos cristais de quartzo. Os cristais maiores de microclínio mostram, por vezes, planos de clivagens pouco abertos e parcialmente preenchidos por sericita e argilominerais. As microfissuras intergrão, pouco freqüentes, mostram-se abertas e preenchidas por sericita, biotita verde (às vezes cloritizadas), opacos disseminados, algum epidoto e raros carbonatos.

Transformações minerais: Fraca alteração mineral caracterizada pela saussuritização dos cristais de plagioclásio e por discreta sericitização do microclínio, o qual ainda pode apresentar algum efeito de argilomineralização (Figura 3.17). Os cristais de plagioclásio são os mais afetados, principalmente em seus núcleos, que além da saussuritização (inclusive com formação de cristais de muscovita bem desenvolvidos), encontram-se fortemente argilomineralizados. A biotita exibe forte desestabilidade, com intensa liberação de titânio e óxido de ferro, denotada pelas freqüentes micro-inclusões de opacos disseminados e de pequenos cristais alongados de titanita secundária preenchendo respectivos planos de geminação. A cloritização é rara nesta rocha.

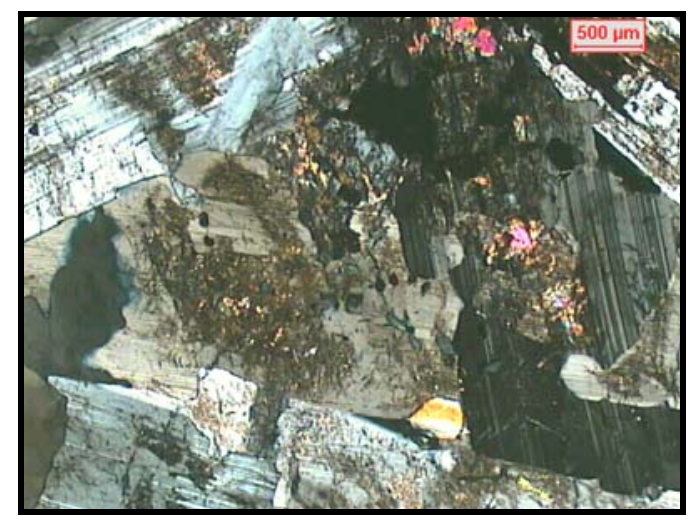

Figura 3.17 - Fotomicrografia mostrando saussuritização dos cristais de plagioclásio e leve sericitização do microclínio (nicóis cruzados). 


\subsection{DEFINIÇÃO DO TRIBOSSISTEMA}

Pelo fato das partes que compõem um tribossistema não poderem ser analisadas de modo isolado, pois se perderia assim a noção de um sistema integrado, em que as características de uma variável irão influir no resultado das outras, optou-se neste item pela apresentação destes grupos sem separação em subitens.

$\mathrm{Na}$ Tribologia original, voltado para o estudo de materiais metálicos, as variáveis relacionadas ao abrasivo utilizado na usinagem da peça (composição química, estrutura, dureza, angularidade, angulosidade, etc.) e às variáveis do processo industrial (velocidade de rotação, ângulo de ataque, etc.) têm exclusiva responsabilidade no registro do sulco na superfície da peça, sendo a amplitude do sulco função de suas propriedades físicas. No caso do polimento de rocha, a seqüência metodológica utilizada nesta pesquisa é descrita na Figura 3.18 .

As diferentes fases minerais irão responder de maneira distintas às solicitações impostas pelo abrasivo e pelas condições operacionais, gerando diferentes graus de rugosidade. Sendo assim, deve-se considerar no caso de rochas, suas características petrográficas como fator de fundamental importância para o resultado final.

Para testar tal hipótese, um primeiro passo dado foi a coleta de amostras dos granitos ornamentais submetidos ao polimento industrial em condições operacionais idênticas (giro de satélite de $600 \mathrm{rpm}$, carga de 2 bars e tempo por etapa de 6 minutos para uma área de aproximadamente $4 \mathrm{~m}^{2}$ ). Esse trabalho foi realizado nas dependências da empresa Granita, situada na cidade de Cachoeiro de Itapemirim, no Estado do Espírito Santo. O número de etapas de desgaste adotado pela empresa para processar o polimento dos materiais foi ao todo dez, na seguinte seqüência: 24 mesh, 36 mesh, 60 mesh, 120 mesh, 220 mesh, 400 mesh, 600 mesh, 800 mesh, 1200 mesh e rebolo de lustro (este último utilizando alumina como abrasivo), totalizando sessenta amostras. Posteriormente, tais amostras foram submetidas a identificação 
da rugosidade da superfície com o auxílio de um rugosímetro de contato modelo Talysurf 1205 de propriedade do Departamento de Metrologia da Escola de Engenharia de São Carlos USP (Figuras 3.19 e 3.20), equipamento este que registra qualquer rugosidade acima de 10 microns . Em seguida, os resultados foram comparados com imagens captadas por uma lupa digital modelo ScalarW50, com capacidade de aumento de 50X, de propriedade do Departamento de Rochas Ornamentais da União de Ensino São Francisco - UNESF (Figuras 3.21 e 3.22). Por fim, foi determinado o brilho de cada amostra com o auxílio de um glossmeter.

Após a análise dos perfis de rugosidade das seis rochas chegou-se a constatação de que rochas com propriedades distintas respondem de maneira diferenciada a uma mesma solicitação de desgaste, se mostrando parte integrante do sistema de desgaste encontrado no polimento de rochas ornamentais. Houve a necessidade de desenvolver um equipamento de laboratório que realizasse ensaios de simulação de polimento, com vista a analisar qual o comportamento de tais materiais frente a diferentes condições operacionais. Tal equipamento recebeu o nome de Simulador de Polimento de Rocha (SPR).

Detalhes do projeto construção do SPR bem como o tratamento dado aos resultados obtidos com tais amostras serão mostrados no Capítulo 4. 


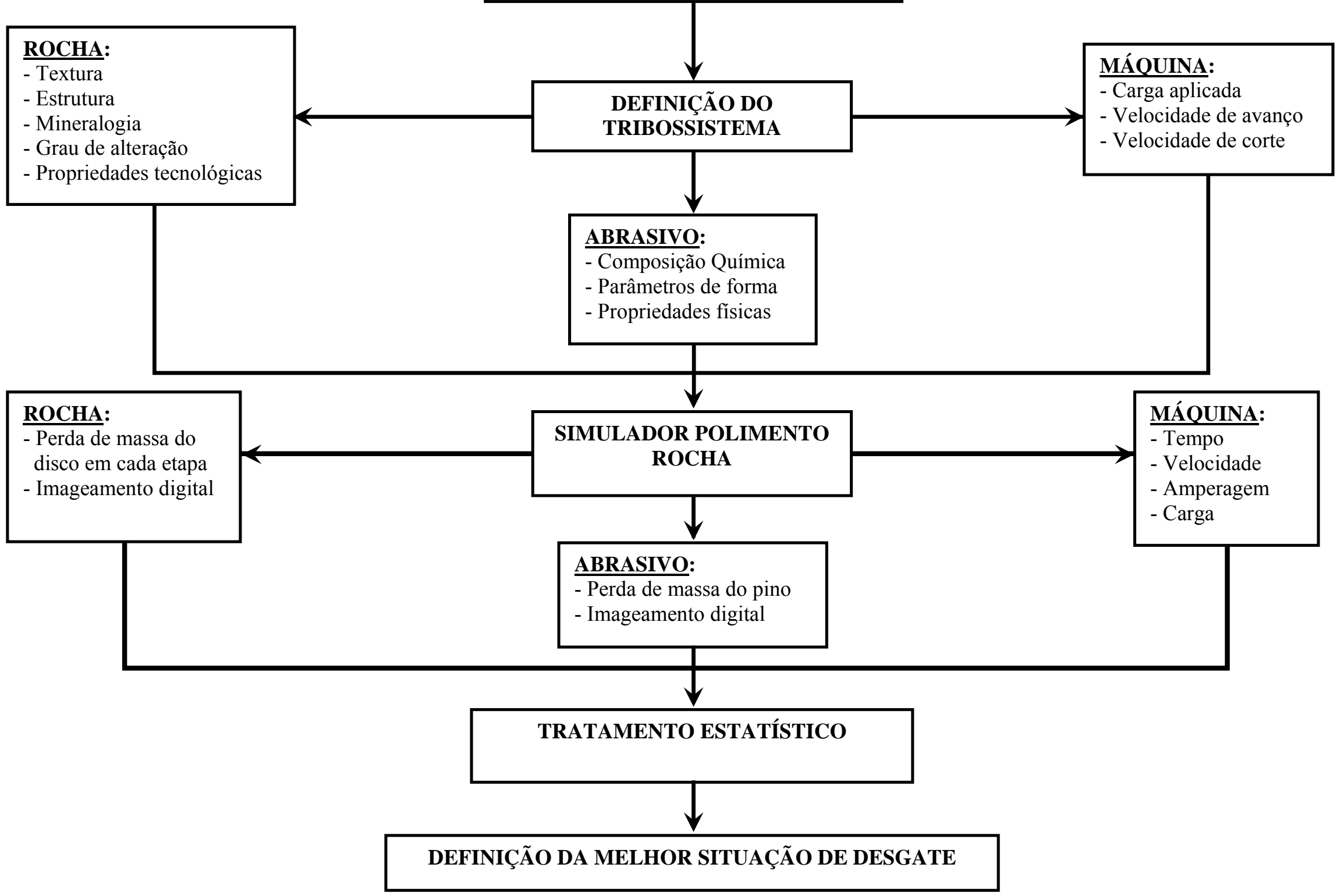

Figura 3.18 - Seqüência metodológica utilizada nesta pesquisa. 


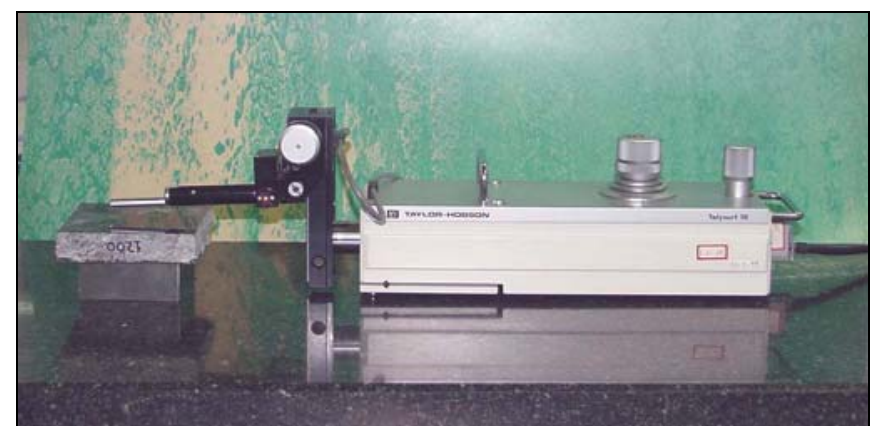

Figura 3.19 - Equipamento utilizado para a medição da rugosidade superficial das amostras de rocha (Talysurf).

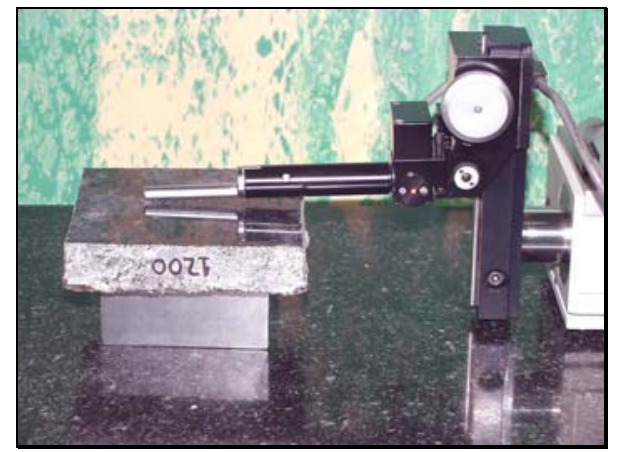

Figura 3.20 - Detalhe do procedimento da determinação da rugosidade das amostras de rocha (Talysurf).

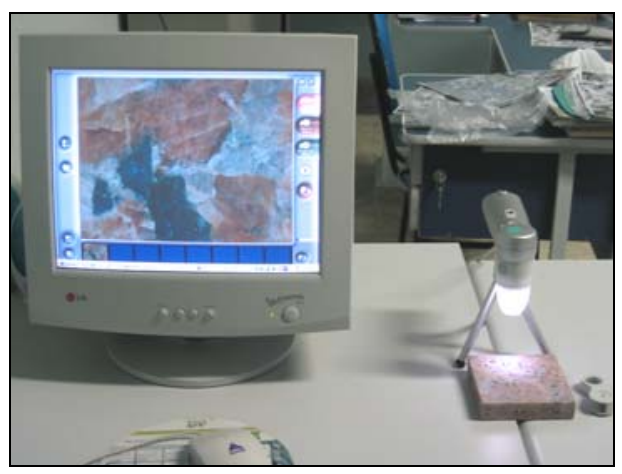

Figura 3.21 - Conjunto lupa digital e imagem captada para análise qualitativa das superfícies das rochas submetidas ao polimento industrial (Scalar W50).

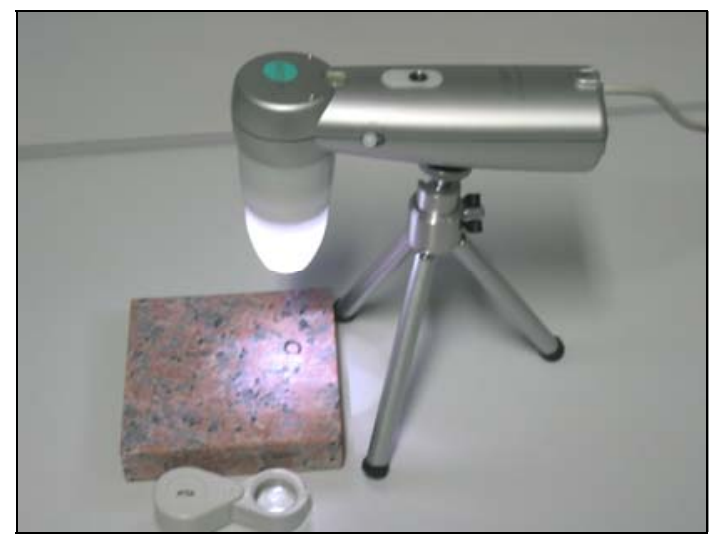

Figura 3.22 - Captação da imagem da superfície da amostra de rocha (Scalar W50). 


\section{4 - RESULTADOS E DISCUSSÕES}

\subsection{RUGOSIDADE DAS SUPERFÍCIES DOS MATERIAIS ESTUDADOS}

Os programas adotados para a geração dos gráficos de superfície foram o Statistica 5.0 e o Excel 2003, a partir de dados absolutos coletados do rugosímetro. A distância percorrida foi colocada no eixo das abscissas e os valores de amplitude do perfil, em valores absolutos (medidos em micrometro), nos eixos das ordenadas. Aproximadamente 800 pontos foram medidos para a geração de cada gráfico, aproximadamente cinco centímetros de caminhamento, sendo realizado um ponto de medida a cada $0,0625 \mathrm{~mm}$. O sentido e a posição de início das medidas foram marcadas em cada amostra, como ilustra a Figura 4.1. As rochas graníticas strictu sensu serão chamada a partir daqui de granitos (Vermelho Brasília, Cinza Castelo e Capão Bonito) e as outras rochas silicatadas não graníticas serão denominadas de “granitos” (Preto Indiano, Desert Storm e Verde Labrador).

Nos perfis que serão apresentados a seguir, foram definidos dois tipos principais de rugosidade. A primeira seria uma superfície com rugosidade de menor amplitude, relacionada com a aspereza da superfície mineral, enquanto que a segunda, em geral com amplitudes maiores, seria devido a contatos entre minerais ou quebra da superfície do mineral (principalmente segundo planos de clivagem), nos quais, provavelmente se desenvolveriam depressões mais acentuadas. A Figura 4.2 ilustra um exemplo dos dois tipos de rugosidade. 


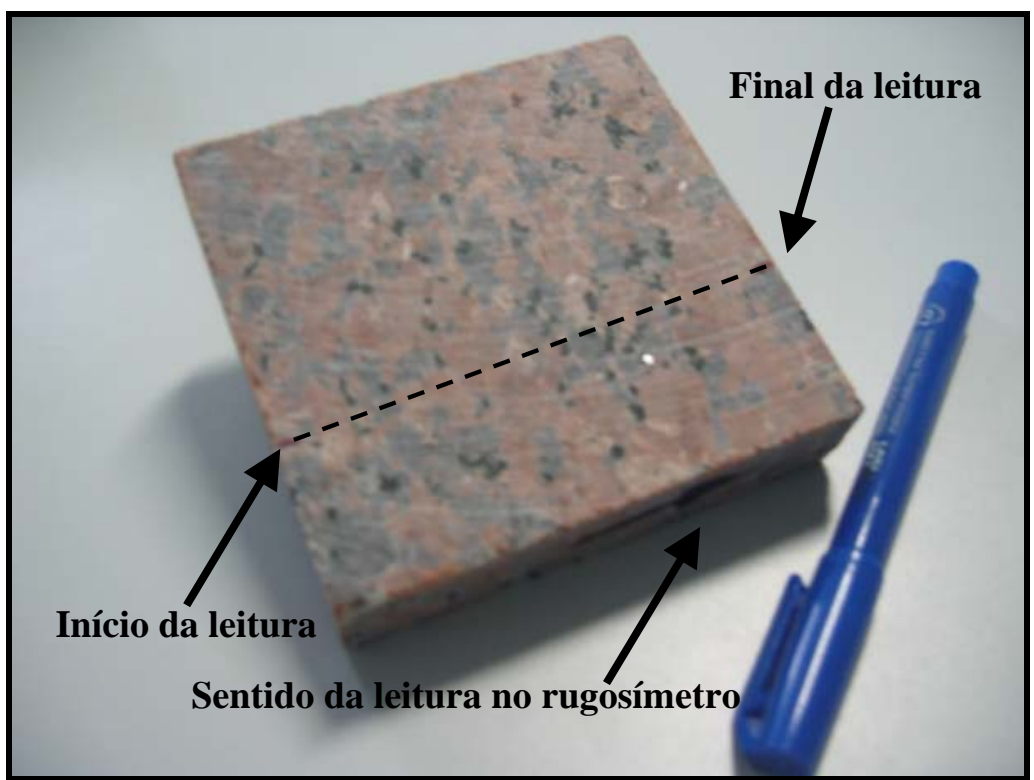

Figura 4.1 - Amostra utilizada na medição da rugosidade superficial dos materiais submetidos ao polimento. Notar a indicação do sentido da leitura bem como os pontos de início e fim.

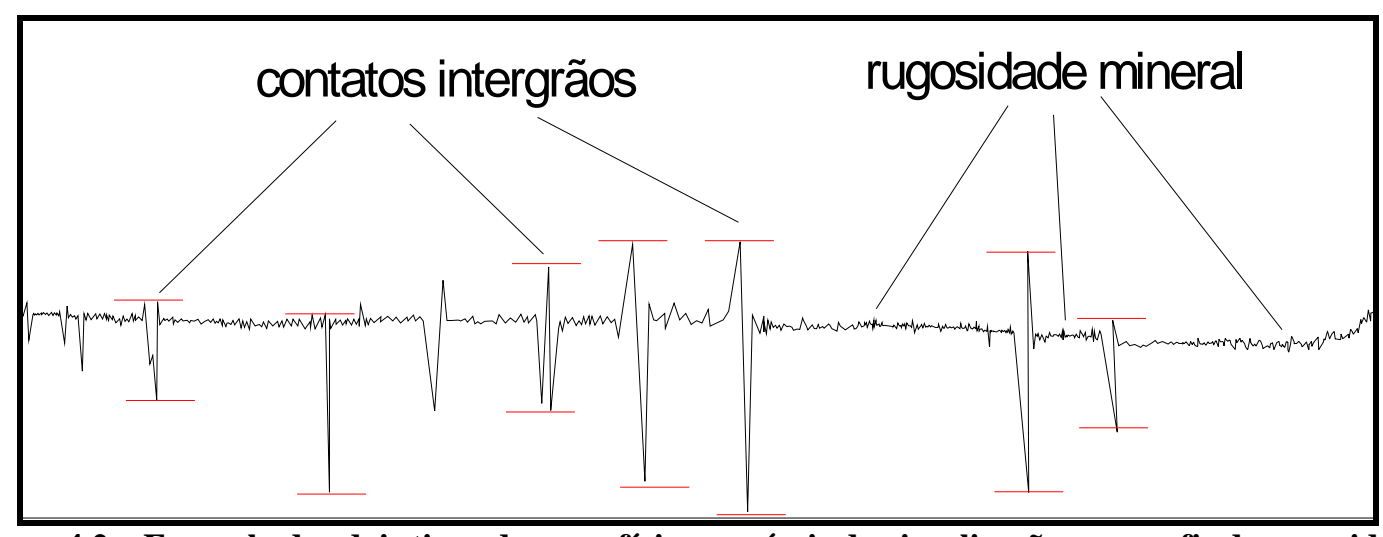

Figura 4.2 - Exemplo dos dois tipos de superfícies possíveis de visualização nos perfis de rugosidade.

\subsubsection{PRIMEIRA ETAPA (\#24 MESH)}

Já na primeira etapa de desgaste fica nítida a influência das propriedades litológicas no tipo de resposta que a rocha apresenta frente às solicitações de desgaste impressas pela máquina e abrasivo. A superfície do "granito" Preto Indiano é irregular, reflexo da anisotropia desta rocha, onde há uma alternância de níveis granoblásticos e lepidoblásticos. Tanto no perfil relacionado a este material quanto aos das outras rochas ainda não é possível determinar qual porção do perfil representa realmente a rugosidade de superfície mineral e qual seria um 
contato intergrão. Nas etapas posteriores, principalmente no Vermelho Brasília, Cinza Castelo, Verde Labrador e Capão Bonito essa distinção se faz com mais clareza. A Figura 4.3 mostra o perfil de rugosidade do "granito" Preto Indiano na primeira fase de desgaste (24 mesh).

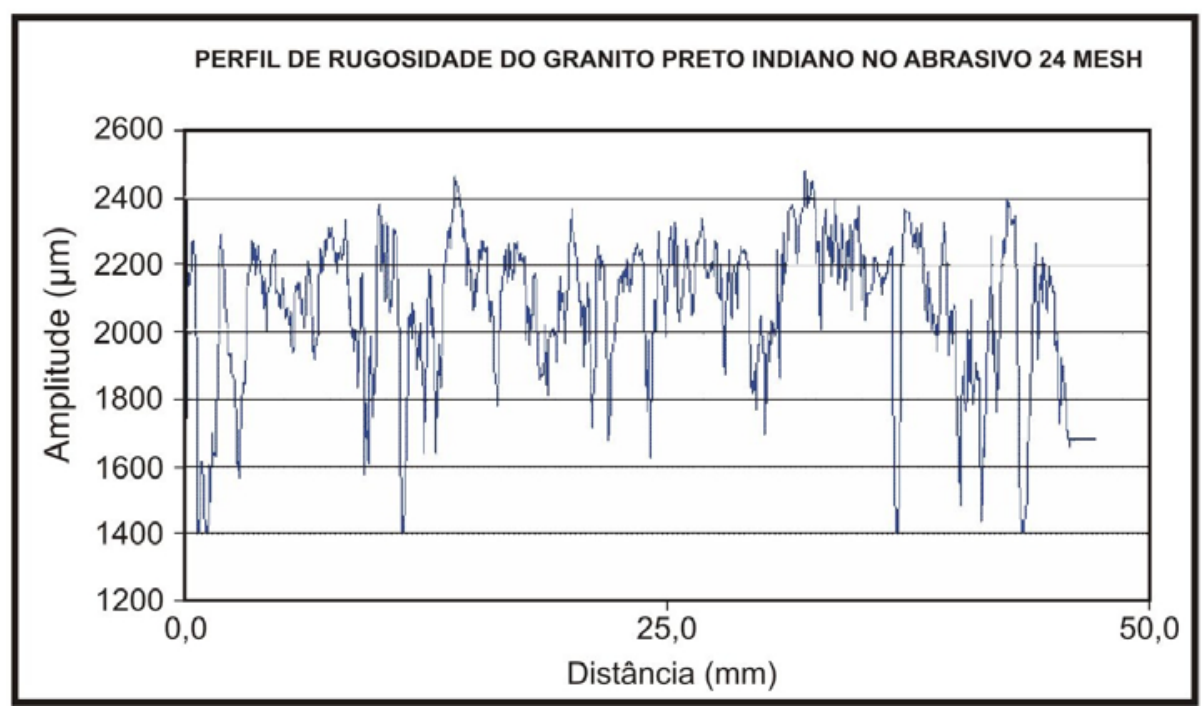

Figura 4.3 - Rugosidade do "granito" Preto Indiano na primeira etapa de desgaste.

É possível observar no gráfico que a Amplitude Máxima Individual $\left(\mathrm{R}_{\text {máx }}\right)$ deste material, nesta etapa, pode chegar a 1000 microns, o que representa a maior diferença em altura, ao longo do perfil, do maior pico para a maior depressão. A distinção entre a rugosidade mineral e os contatos entre os níveis micáceos e granulares ainda é de difícil visualização, visto que a granulometria do abrasivo imprime um risco muito proeminente e a superfície ainda apresenta sulcos herdados da etapa de serragem (Figura 4.4). 


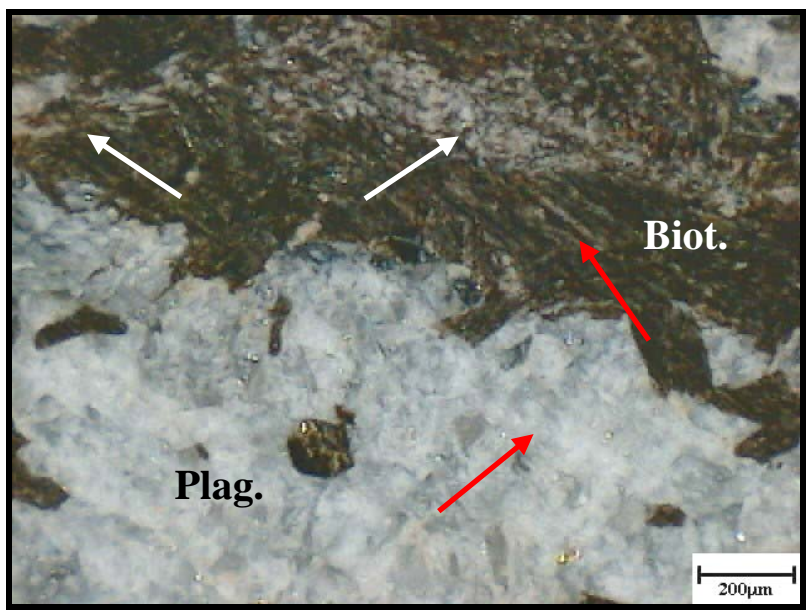

Figura 4.4 - Amostra do "granito" Preto Indiano submetido a solicitações de desgaste com abrasivo 24 mesh. Notar a presença dos riscos gerados pelo abrasivo (seta vermelha) e regiões com feições originais da serragem (seta branca).

Analisando o perfil do granito Vermelho Brasília, algumas considerações são pertinentes: granitos considerados duros quando serrados, a princípio, tendem a apresentar chapas com superfícies com mais imperfeições, principalmente devido ao fato de que a cala (descida do quadro porta-lâminas do tear) nestes tipos de granitos se processa de modo mais lento e o desgaste a três corpos que ocorre na serragem tende a causar danos à rocha. Quando tal material é submetido ao polimento, os sulcos herdados da serrada tendem ocorrer de modo mais intenso, em relação a materiais mais “moles" (Figura 4.5). Isto é refletido no perfil de rugosidade, que apresenta poucas variações bruscas de $R_{\max }$, chegando a 900 microns. Tal aspecto está também relacionado à sua maior isotropia em relação ao "granito" Preto Indiano. Essa rocha apresenta também as maiores ranhuras oriundas do abrasivo (Figura 4.6). 


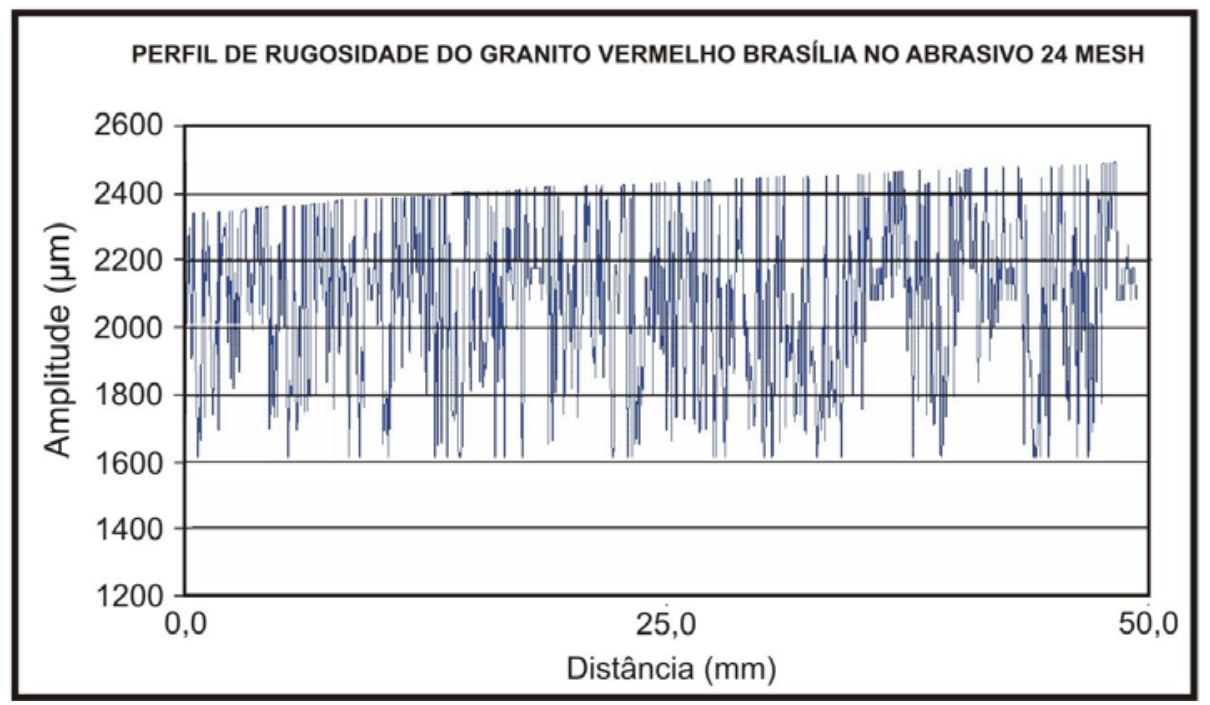

Figura 4.5 - Rugosidade do granito Vermelho Brasília na primeira etapa de desgaste.

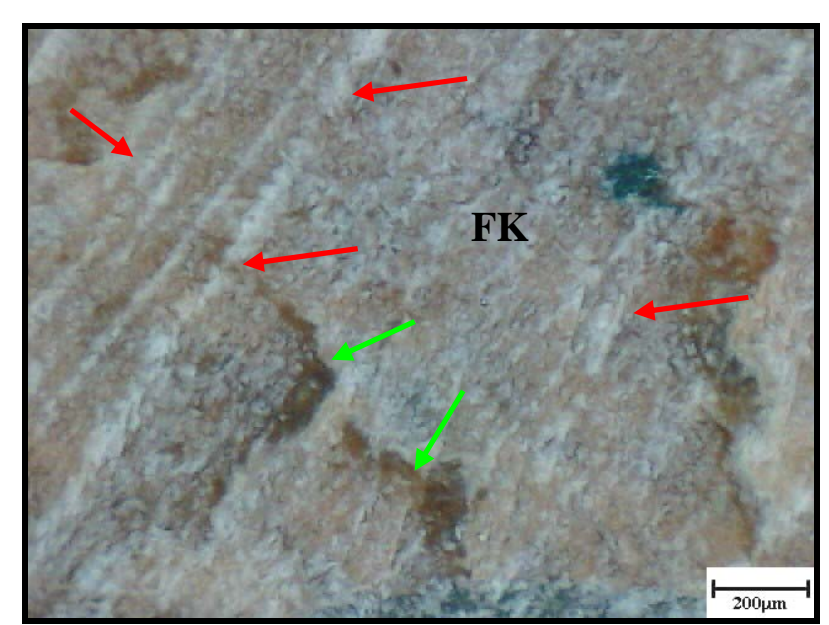

Figura 4.6 - Amostra do granito Vermelho Brasília submetido a solicitações de desgaste com abrasivo 24 mesh. Notar a presença dos riscos gerados pelo abrasivo (seta vermelha) e depressões que acompanham planos de clivagem (setas verdes) e ausência de depressões herdadas da serrada.

A Amplitude Máxima $\left(\mathrm{R}_{\max }\right)$ verificada no perfil de rugosidade do granito Cinza Castelo, na primeira fase de desgaste, é de 500 microns, mostrando que rochas mais finas tendem a apresentar melhor acabamento. A textura fina do granito Cinza Castelo propicia uma diminuição natural de contatos intergrão, ou de certa forma, camufla tais contatos e os confunde com planos de rugosidade mineral. Aliado a isso, o fato desta rocha ser consideravelmente isotrópica, dificulta ainda mais a separação entre os dois tipos de rugosidade (Figura 4.7). 


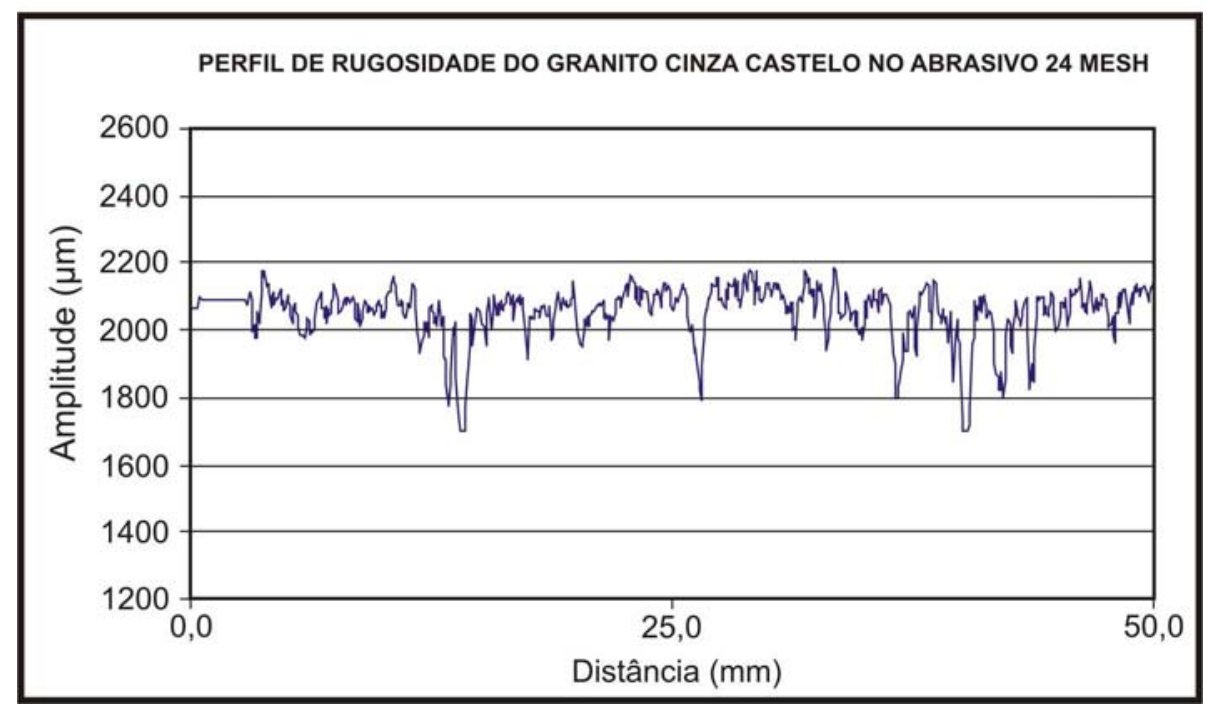

Figura 4.7 - Rugosidade do granito Cinza Castelo na primeira etapa de desgaste.

É possível notar que já nesta fase, a superfície da rocha apresenta-se mais suavizada em relação às rochas anteriores (Figura 4.8).

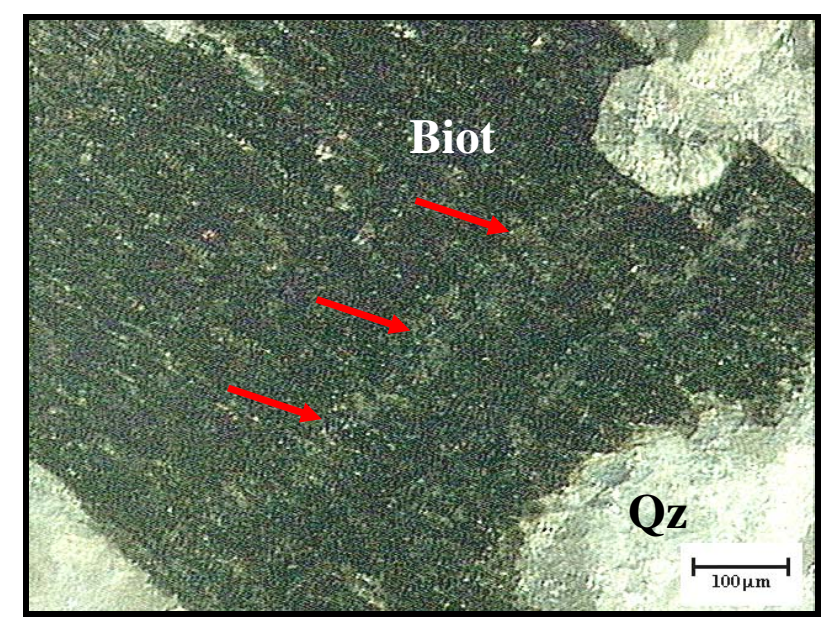

Figura 4.8 - Amostra do granito Cinza Castelo submetido a solicitações de desgaste com abrasivo 24 mesh. Notar a presença dos riscos gerados pelo abrasivo (seta vermelha).

O "granito" Desert Storm, a segunda rocha tipicamente anisotrópica em relação a estrutura, juntamente com o "granito" Preto Indiano, apresenta na primeira fase de desgaste um indício de separação entre os dois tipos de rugosidade (contato intergrão e rugosidade mineral). Vale lembrar que esta rocha apresenta estrutura e textura bastante heterogêneas, o que pode dificultar a visualização destes dois tipos de rugosidade. $\mathrm{O} \mathrm{R}_{\max }$ verificado neste perfil é de aproximadamente 500 microns (Figura 4.9). É possível comprovar que tal material 
apresenta um intenso fraturamento, tanto intragrãos quanto intergrãos, o que também pode falsear uma possível divisão entre os dois tipos de rugosidade (Figura 4.10).

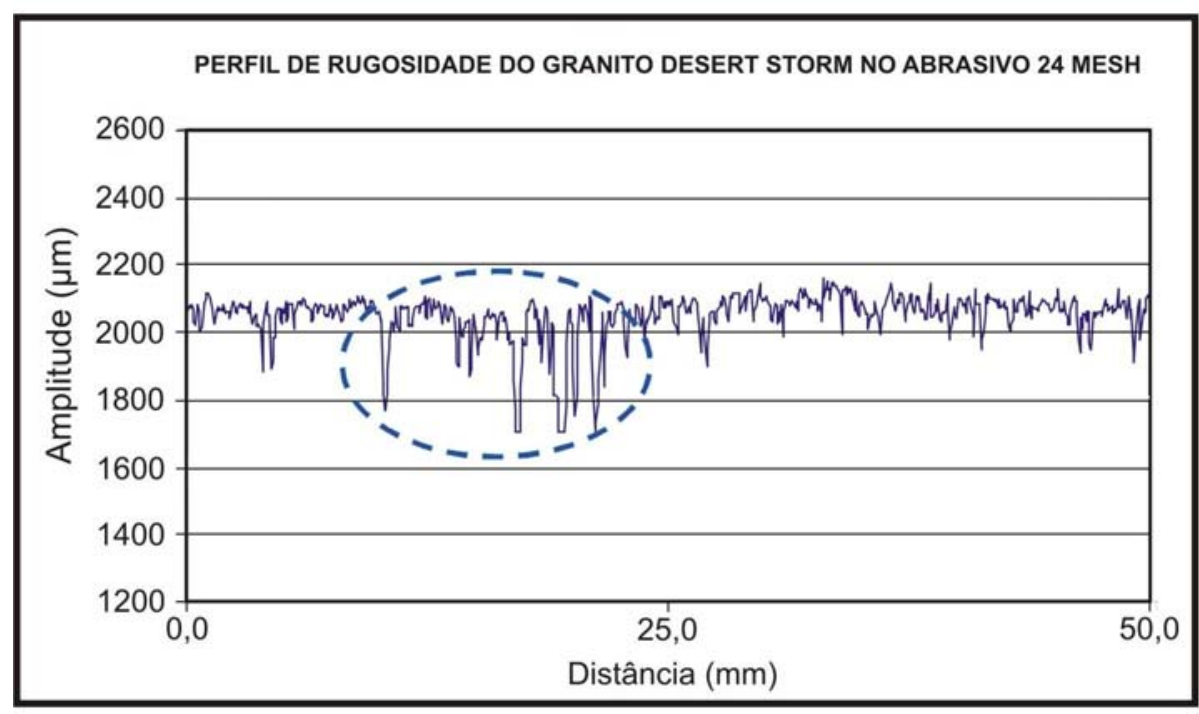

Figura 4.9 - Rugosidade do “granito” Desert Storm na primeira etapa de desgaste. $O$ círculo tracejado indica um início de separação entre a rugosidade mineral e o contato intergrão.

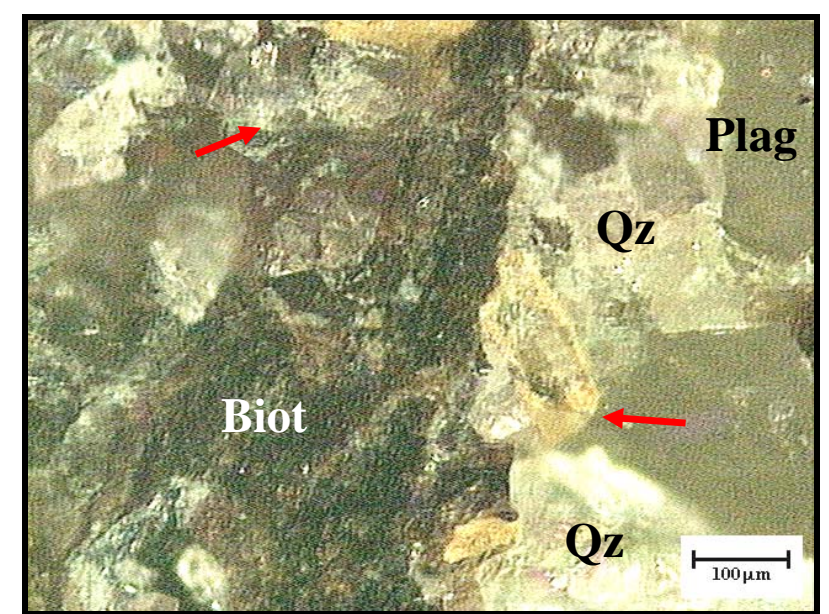

Figura 4.10 - Amostra do “granito” Desert Storm submetido a solicitações de desgaste com abrasivo 24 mesh. Notar a presença de intenso microfissuramento e de riscos gerados pelo abrasivo (seta vermelha).

Na primeira fase de desgaste, o "granito" Verde Labrador apresenta um perfil de rugosidade com $\mathrm{R}_{\max }$ de 600 microns, porém com uma superfície mais irregular do que as anteriores (Figura 4.11). Isto se deve ao fato de que existe uma considerável quantidade de microfissuras no interior dos cristais de feldspato potássico (ortoclásio), fato esse que tende a diminuir ao longo das outras etapas de desgaste (Figura 4.12). 


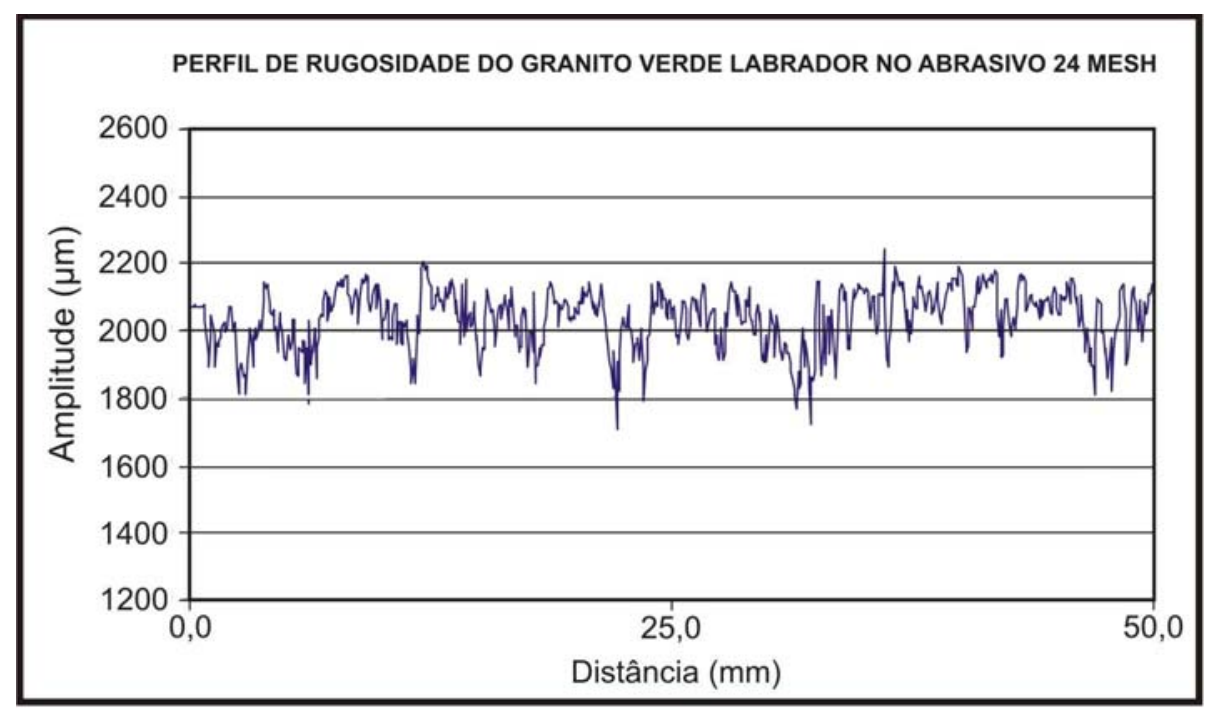

Figura 4.11 - Rugosidade do “granito” Verde Labrador na primeira etapa de desgaste.

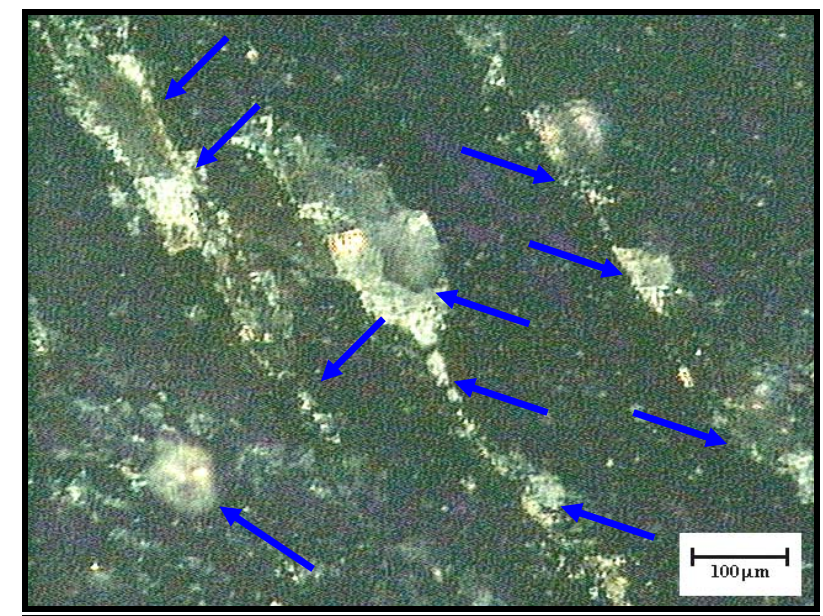

Figura 4.12 - Amostra do "granito” Verde Labrador a solicitações de desgaste com abrasivo 24 mesh. Notar microfissuras no interior de um cristal de ortoclásio (setas azuis).

O granito Vermelho Capão Bonito apresenta $\mathrm{R}_{\max }$ de 1000 microns, possivelmente oriundo de uma má qualidade de serragem (Figura 4.13). Esta amostra apresenta um intenso fraturamento intra e intergrão, o que também contribui para um aumento da rugosidade (Figura 4.14). 


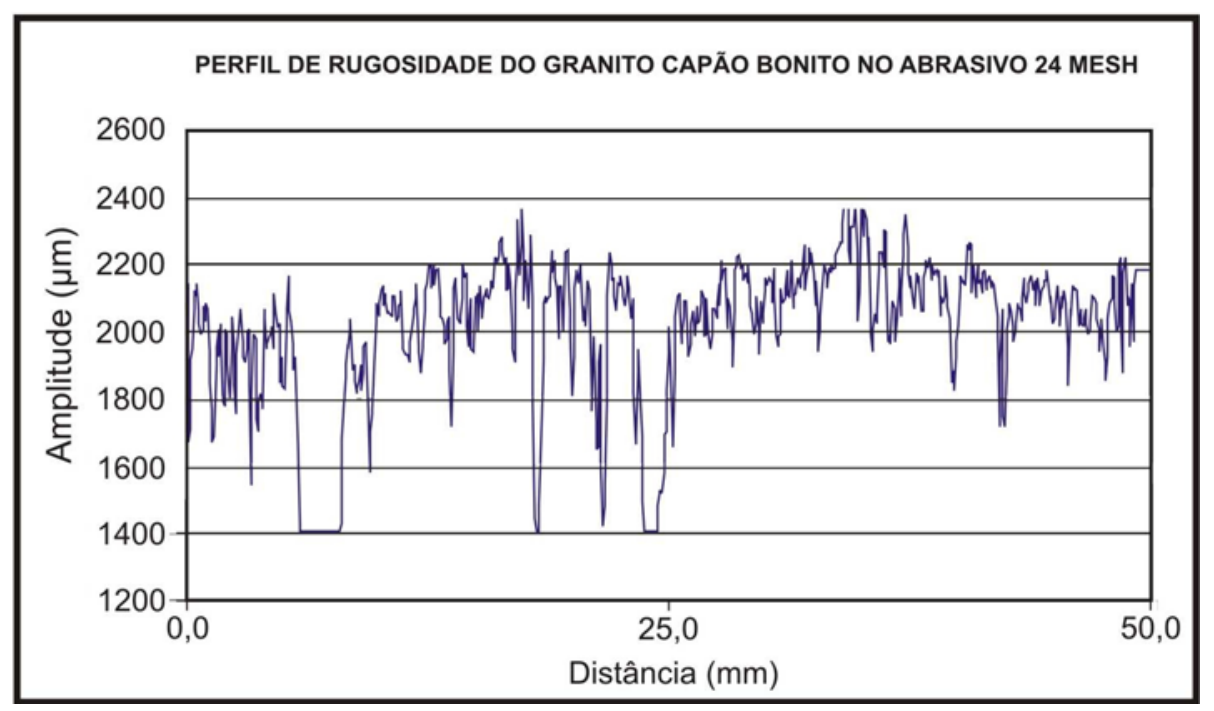

Figura 4.13 - Rugosidade do granito Vermelho Capão Bonito na primeira etapa de desgaste.

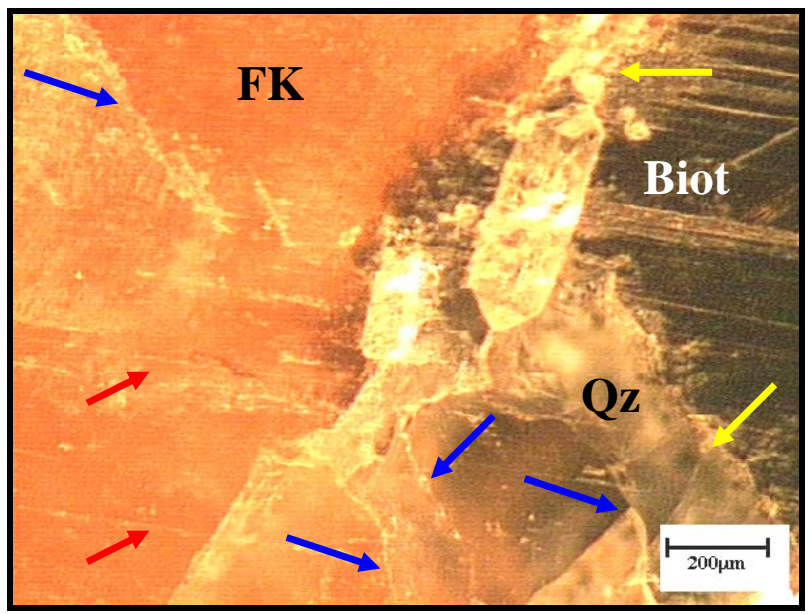

Figura 4.14 - Granito Vermelho Capão Bonito submetido a solicitações de desgaste com abrasivo 24 mesh. Notar microfissuras intergrão (setas amarelas) e intragrão (setas azuis) e riscos causados pelo abrasivo (setas vermelhas).

\subsubsection{SEGUNDA ETAPA (\#36 MESH)}

Em relação ao perfil de rugosidade do "granito" Preto Indiano é possível notar uma maior tendência a gerar a separação entre os dois tipos de rugosidade propostos neste trabalho, embora ainda não esteja nítido (Figura 4.15). Isto significa que os riscos gerados pelo abrasivo ainda são maiores que uma possível diferença de rugosidades de uma superfície mineral ou um contato entre grãos. Os valores de $\mathrm{R}_{\max }$, com exceção de um ponto, se aproximam de 900 microns. 
Devido à pequena variação na granulometria do abrasivo, em relação à etapa anterior, as marcas geradas nesta etapa apresentam o mesmo porte, com a diferença de ocorrer uma diminuição, em área, dos sulcos originais da serragem do bloco (Figura 4.16).

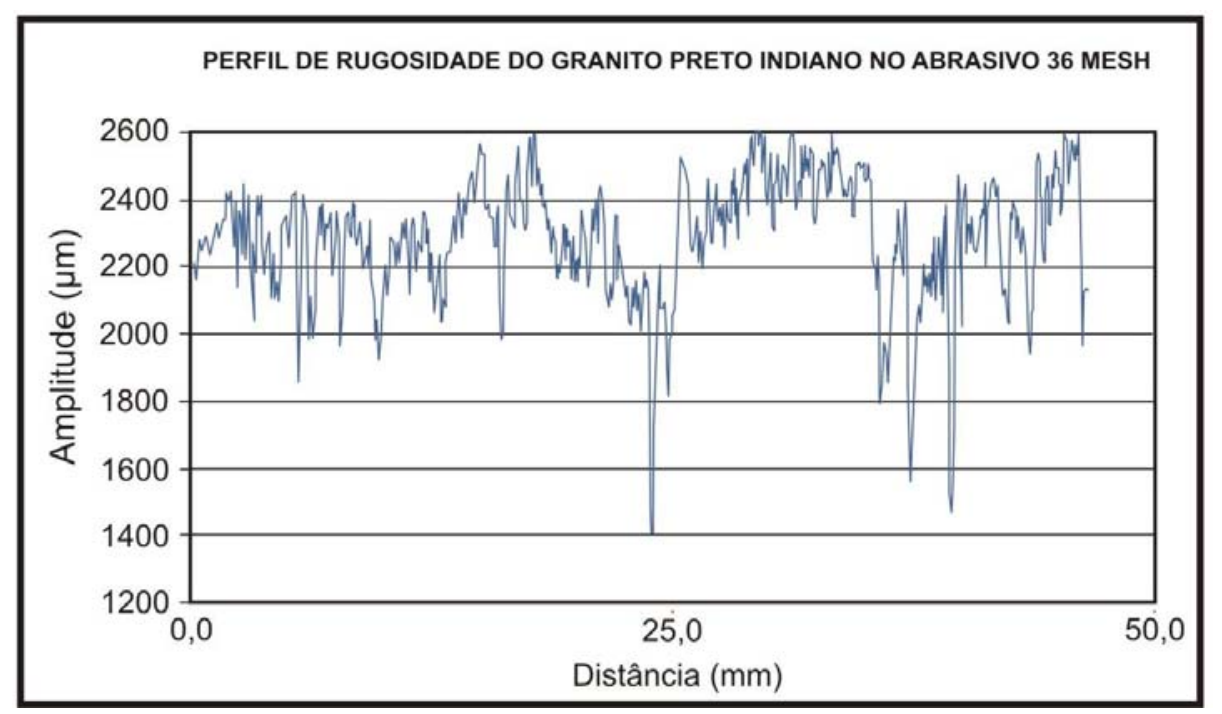

Figura 4.15 - Rugosidade do “granito” Preto Indiano na segunda etapa de desgaste.

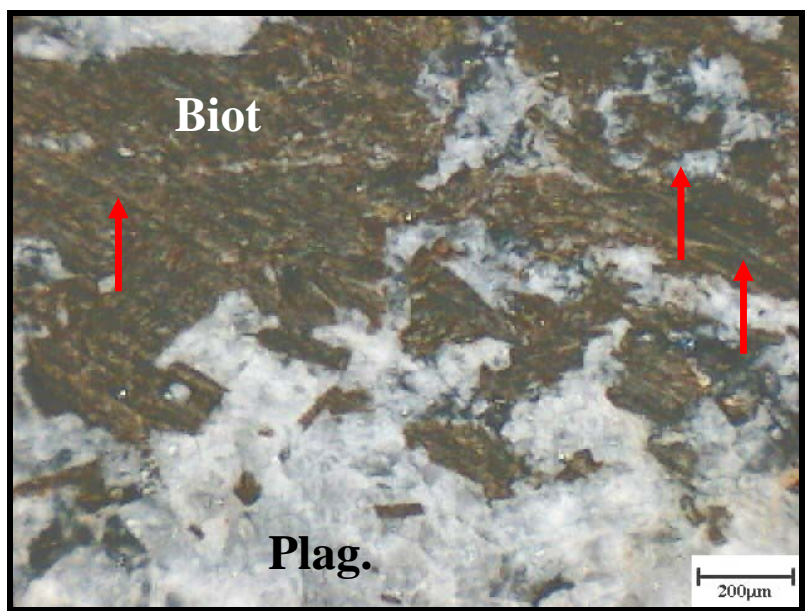

Figura 4.16 - Amostra do "granito” Preto Indiano submetido a solicitações de desgaste com abrasivo 36 mesh. Notar a diminuição, em área, das porções originais da serragem e visualização ainda de riscos oriundos do abrasivo (seta vermelha).

Na segunda etapa de desgaste o granito Vermelho Brasília apresentou uma sensível diminuição nos valores de $\mathrm{R}_{\max }$, atingindo aproximadamente 500 microns. É possível visualizar a estrutura isotrópica deste material no perfil de rugosidade (Figura 4.17). 


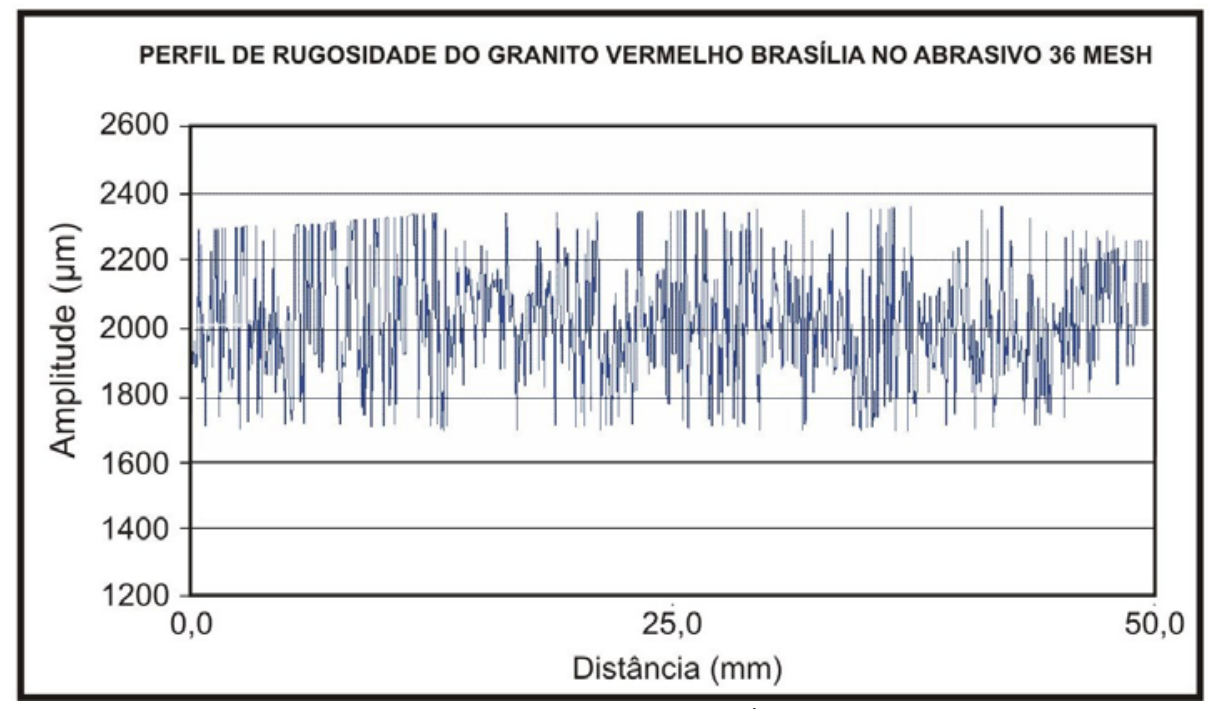

Figura 4.17 - Rugosidade do granito Vermelho Brasília na segunda etapa de desgaste.

Nesta fase de desgaste, a superfície do granito Vermelho Brasília apresenta riscos do abrasivo de polimento, porém, está livre das irregularidades oriundas da serragem (Figura 4.18).

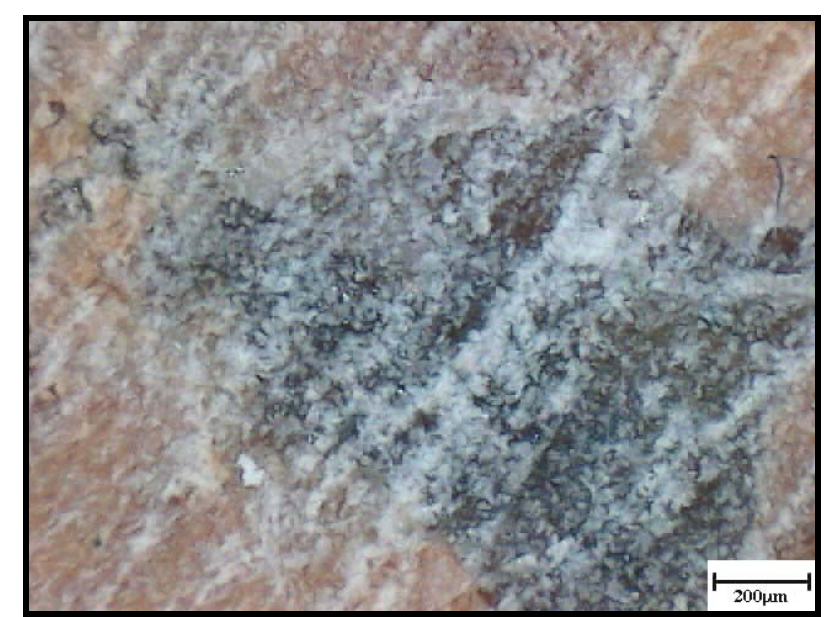

Figura 4.18 - Amostra do granito Vermelho Brasília submetido a solicitações de desgaste com abrasivo 36 mesh. Notar a existência apenas, porém intensa, de riscos produtos da ação do abrasivo.

Da primeira para a segunda fase de desgaste, o granito Cinza Castelo apresentou uma diminuição de $\mathrm{R}_{\max }$ da ordem de 100 microns, ficando com aproximadamente 400 microns nesta etapa (Figura 4.19). É possível notar riscos gerados pelos abrasivos mais fortemente marcados nas lamelas de biotita e pouca quantidade de microfissuras intragrão (Figura 4.20). 


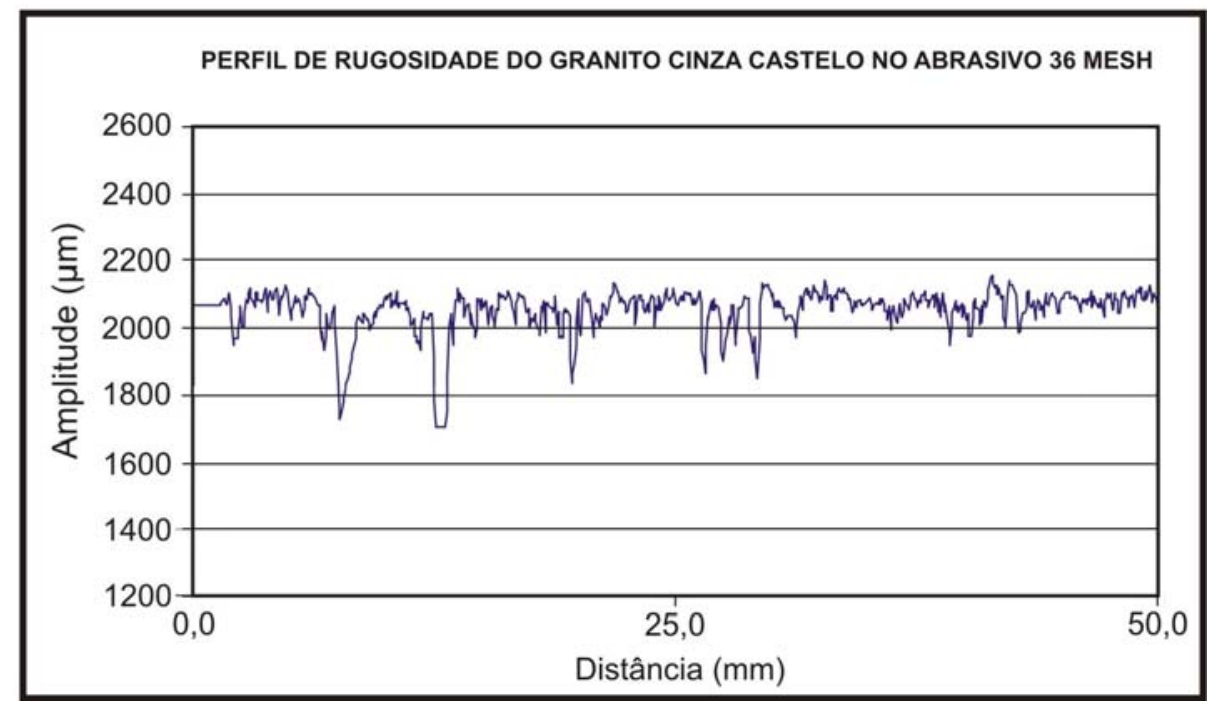

Figura 4.19 - Rugosidade do granito Cinza Castelo na segunda etapa de desgaste.

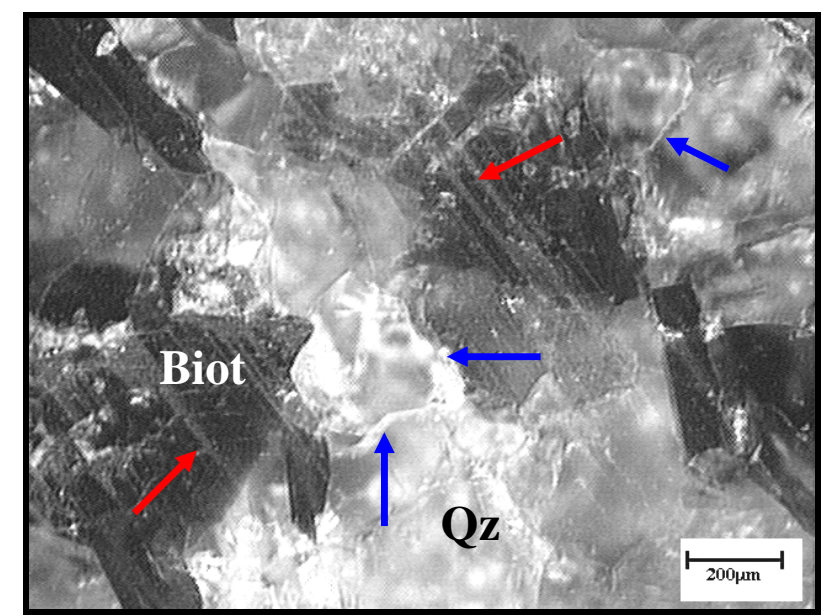

Figura 4.20 - Amostra do granito Cinza Castelo submetido a solicitações de desgaste com abrasivo 36 mesh. Notar a existência de riscos mais proeminentes nas biotitas e pouco microfissuramento intragrão (seta azul).

O "granito" Desert Storm apresentou nesta fase, um ligeiro aumento no valor de $\mathrm{R}_{\max }$ (500 microns) o que pode ser explicado devido à passagem da ponta do rugosímetro sobre uma porção mais micácea, o que daria uma variação considerável de pico e vale, por causa da disposição das lamelas de biotita (Figura 4.21). Observa-se a presença de microfissuras intragrão e intergrão, além de riscos gerados pelo abrasivo (Figura 4.22). 


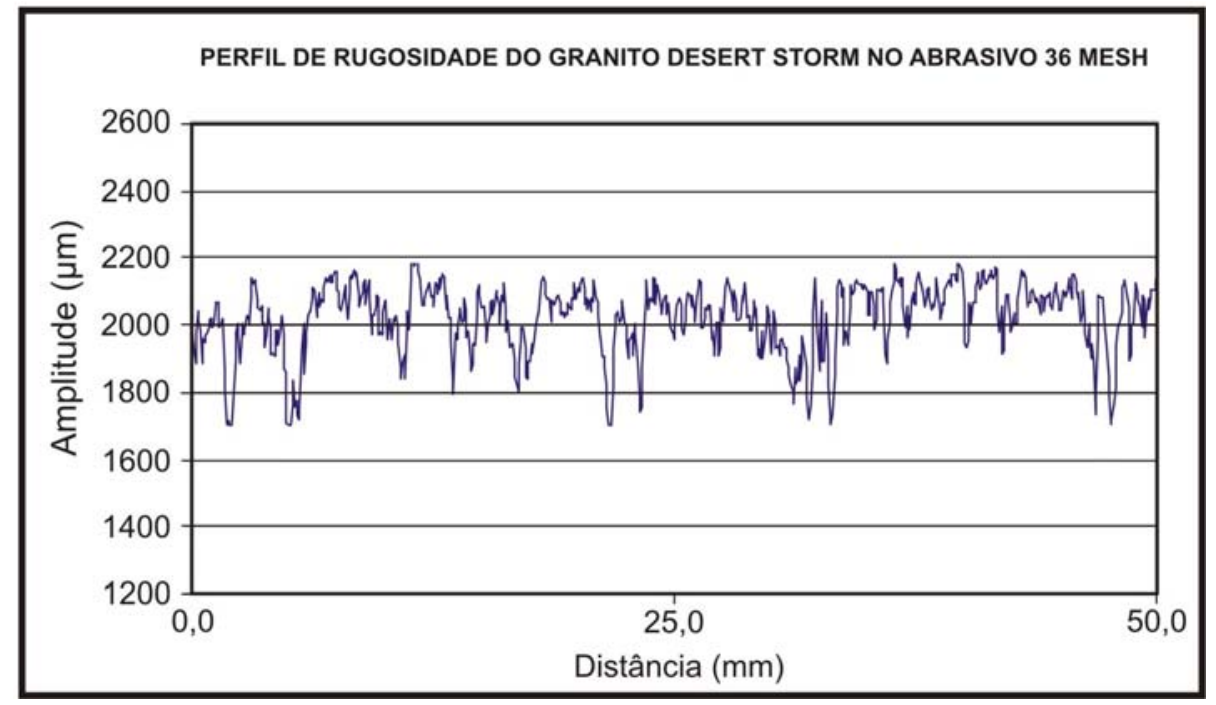

Figura 4.21 - Rugosidade do “granito” Desert Storm na segunda etapa de desgaste.

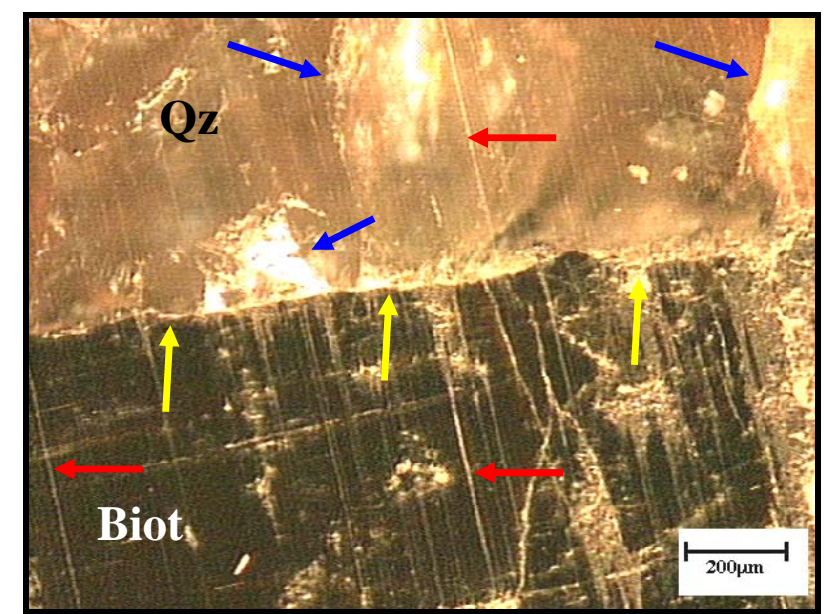

Figura 4.22 - Amostra do "granito" Desert Storm submetido a solicitações de desgaste com abrasivo 36 mesh. Notar microfissuras intergrão (setas amarelas) e intragrão (setas azuis) e riscos causados pelo abrasivo (setas vermelhas).

O “granito" Verde Lavrador apresentou um $\mathrm{R}_{\max }$ de 400 microns, diminuindo cerca de 200 microns em relação etapa anterior (Figura 4.23). É possível verificar que as microfissuras intragrãos, comuns na primeira fase diminuíram consideravelmente (Figura 4.24). 


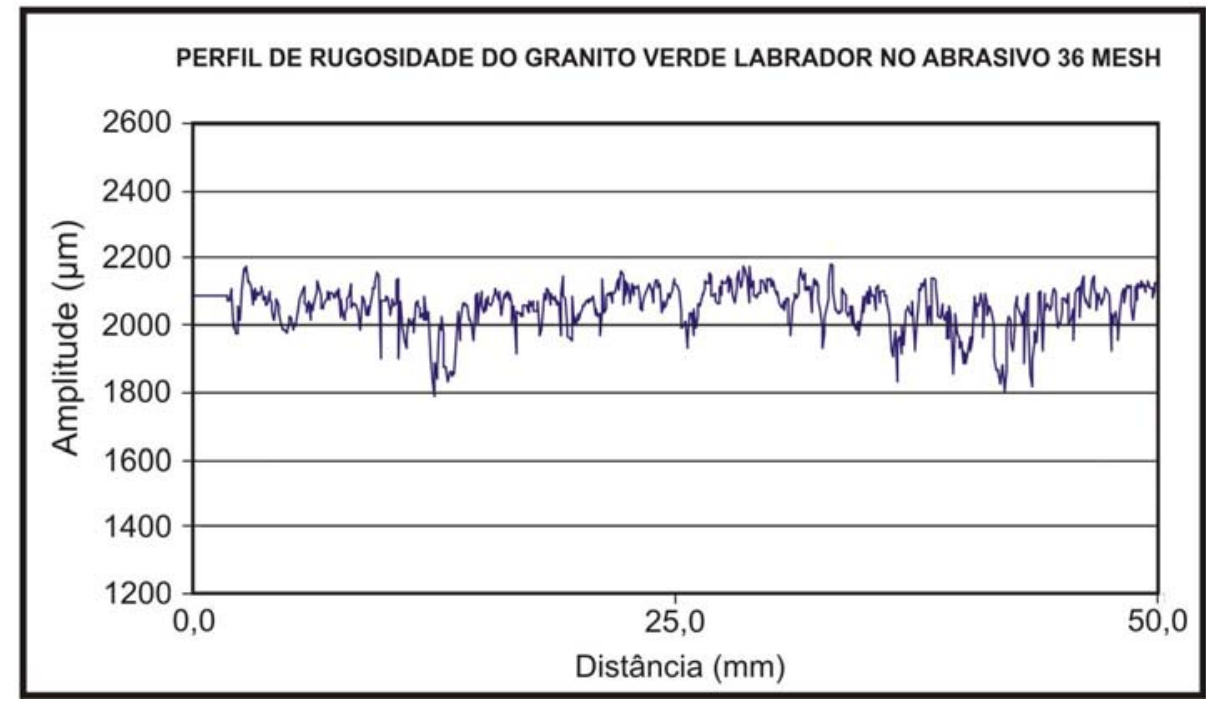

Figura 4.23 - Rugosidade do “granito” Verde Labrador na segunda etapa de desgaste.

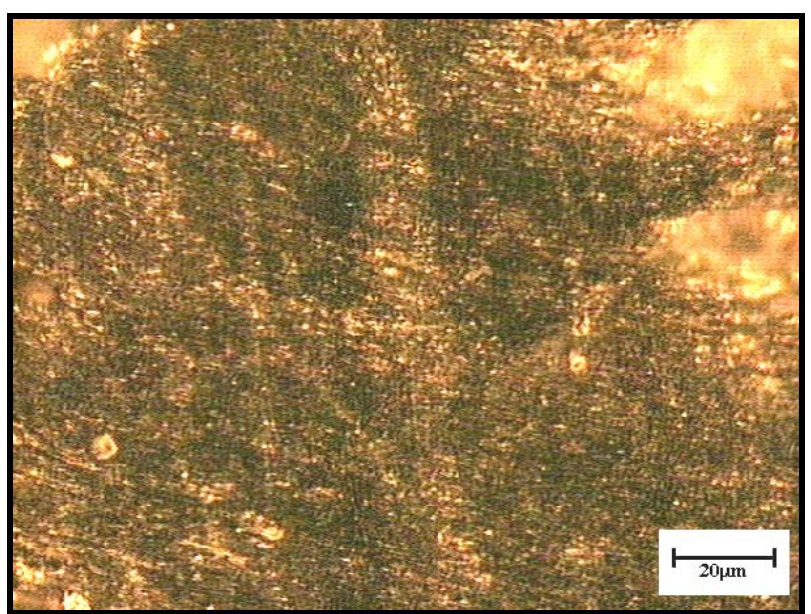

Figura 4.24 - Amostra do “granito” Verde Labrador submetido a solicitações de desgaste com abrasivo 36 mesh.

Nesta fase o granito Vermelho Capão Bonito apresentou um padrão diferenciado do previsto para um material isotrópico, com algumas depressões atingindo 700 microns (Figura 4.25). Tal fato se deve, possivelmente, a um intenso microfissuramento que se desenvolve ao longo das etapas de desgaste (Figura 4.26). Um fato interessante é que ambos os sienogranitos aqui estudados (Vermelho Brasília e Capão Bonito) apresentam magnitudes de $\mathrm{R}_{\max }$ semelhantes, indicando que rochas com características idênticas, respondem de modo parecido às solicitações impostas pelo processo de polimento. 


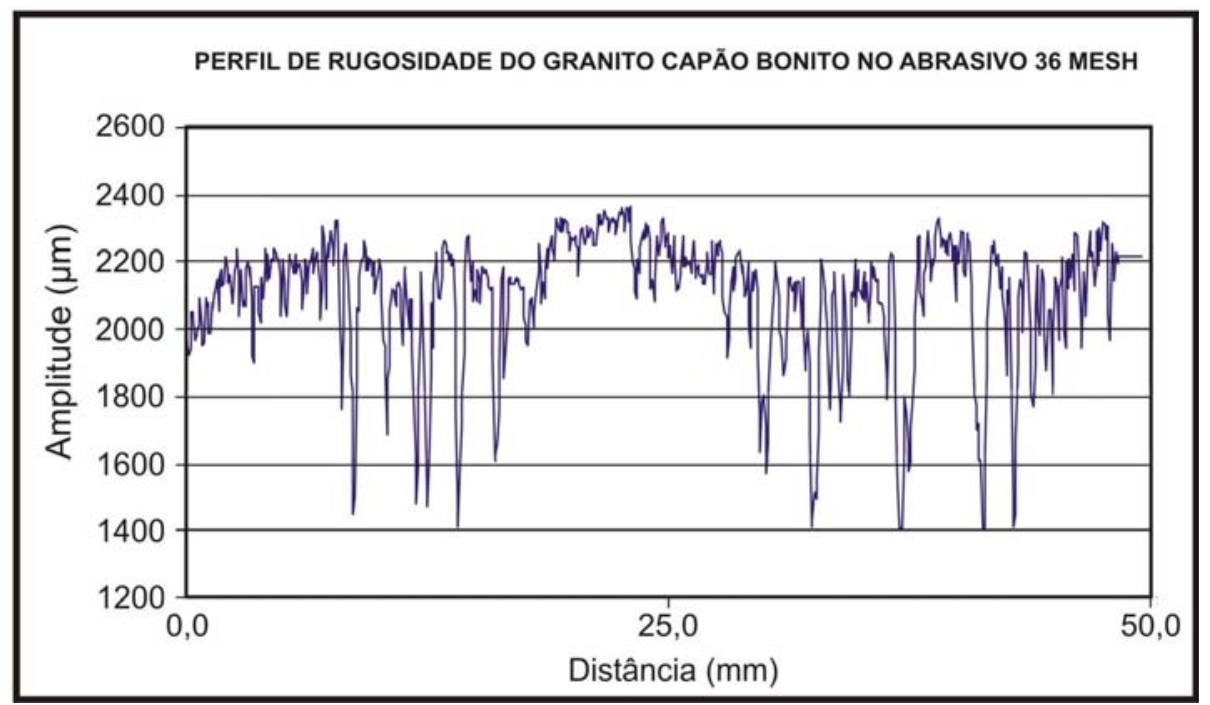

Figura 4.25 - Rugosidade do granito Vermelho Capão Bonito na segunda etapa de desgaste.

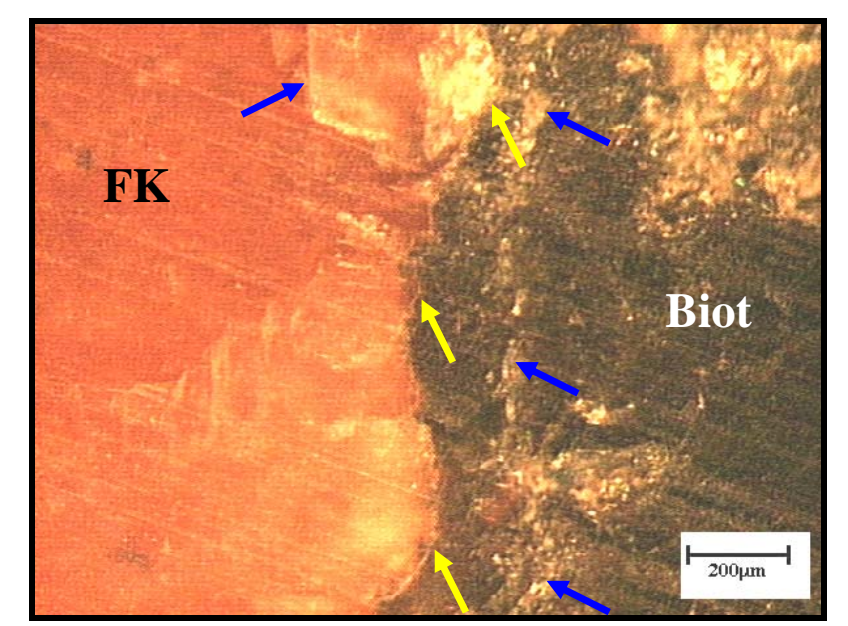

Figura 4.26 - Amostra do granito Vermelho Capão Bonito submetido a solicitações de desgaste com abrasivo 36 mesh. Notar intenso microfissuramento intergrão (seta amarela) e intragrão (seta azul), além de riscos produzidos pelo abrasivo (seta vermelha).

\subsubsection{TERCEIRA ETAPA (\#60 MESH)}

A terceira etapa de desgaste é considerada a última fase de desbaste, que consiste na remoção mais severa de material e precede a etapa de levigamento (\#120), que é a fase préresinagem, representando assim um estádio de mudança na intensidade da taxa de desgaste.

O "granito" Preto Indiano mostra nesta fase uma rugosidade de aproximadamente de 600 microns, sendo possível visualizar com melhor resolução a separação entre as rugosidades mineral e a que ocorre nos contatos ente minerais (Figura 4.27). Isto é possível 
notar também nas imagens de superfície da amostra, que evidencia uma diferença na intensidade da ranhura quando comparados os domínios micáceos com os granulares (Figura 4.28).

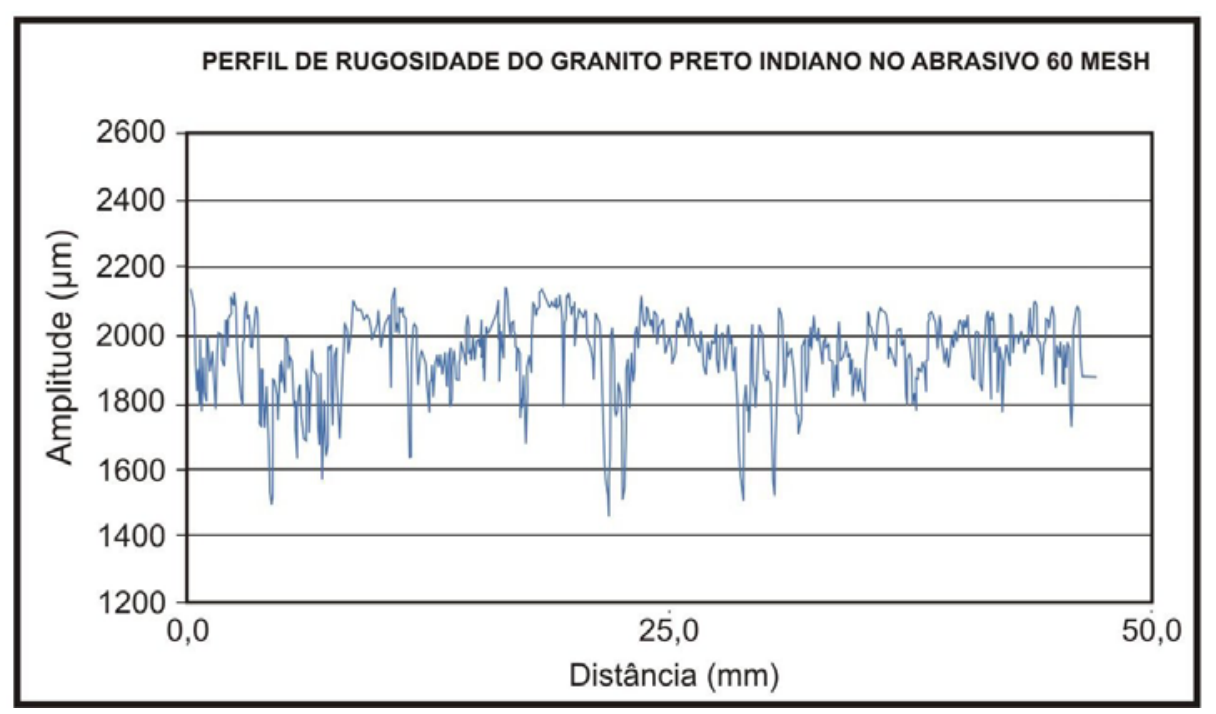

Figura 4.27 - Rugosidade do “granito” Preto Indiano na terceira etapa de desgaste.

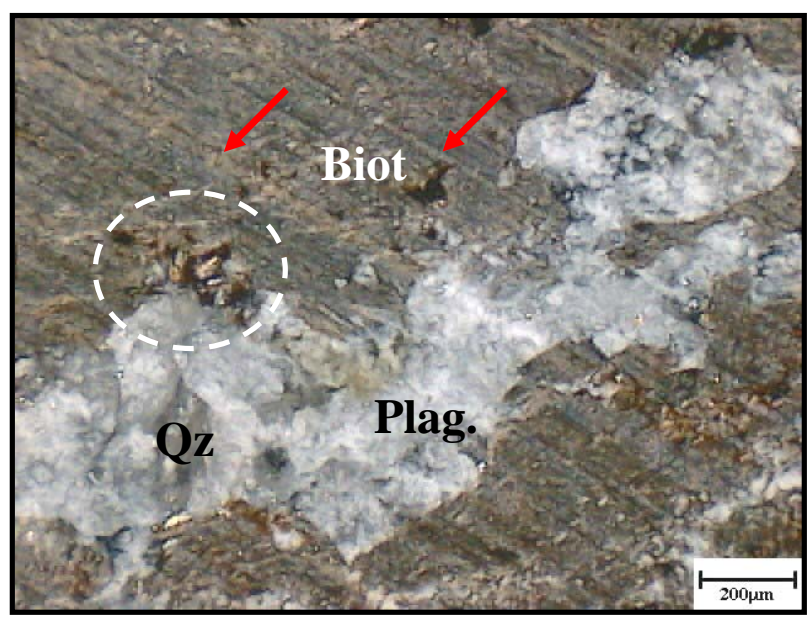

Figura 4.28 - Amostra do "granito" Preto Indiano submetido a solicitações de desgaste com abrasivo 60 mesh. Notar desplacamento de lamelas (tracejado) e a maior quantidade de ranhuras produzidas na biotita (seta vermelha).

O granito Vermelho Brasília continua mantendo, nesta fase, uma maior homogeneidade no seu perfil de rugosidade. Os valores de $\mathrm{R}_{\max }$ ficaram em torno dos 230 microns, o que representa uma superfície quase três vezes menos rugosa, se comparado com o gnaisse Preto Indiano na mesma fase de desgaste (Figura 4.29). 
A terceira etapa de desgaste representa também a última fase do chamado desbaste, como já foi dito anteriormente. No Granito Vermelho Brasília ainda se vê o predomínio dos riscos feitos pelo rebolo abrasivo (Figura 4.30).

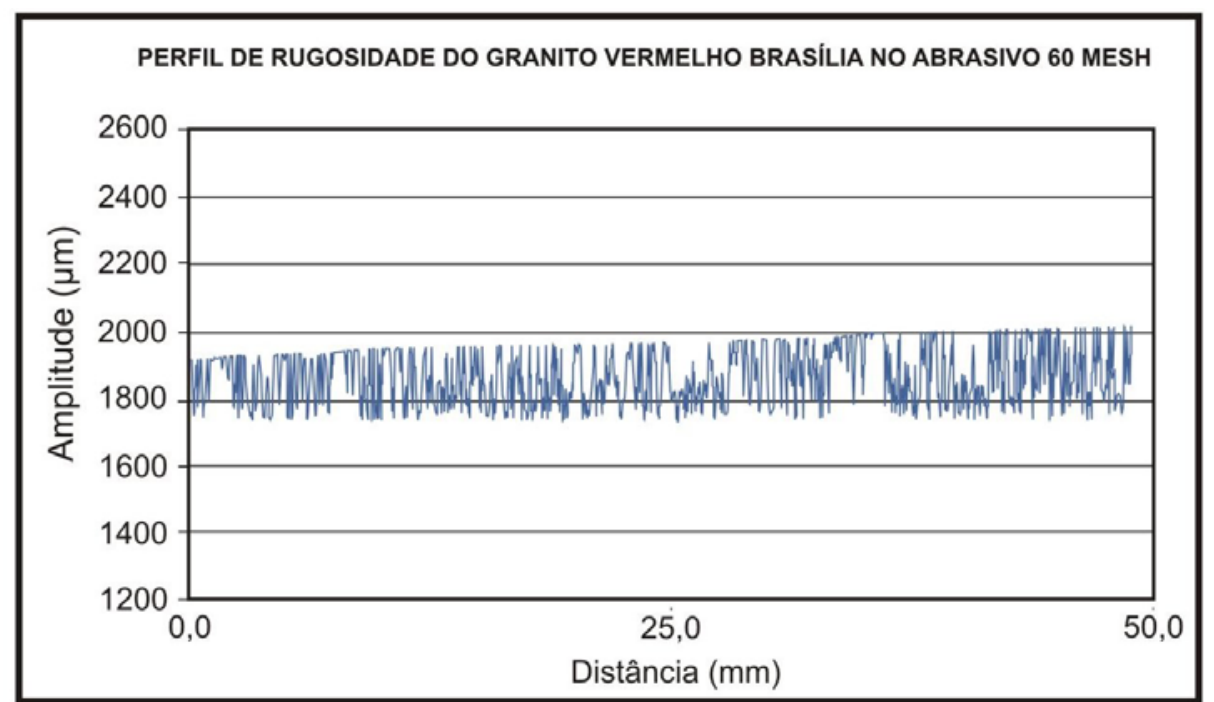

Figura 4.29 - Rugosidade do granito Vermelho Brasília na terceira etapa de desgaste.

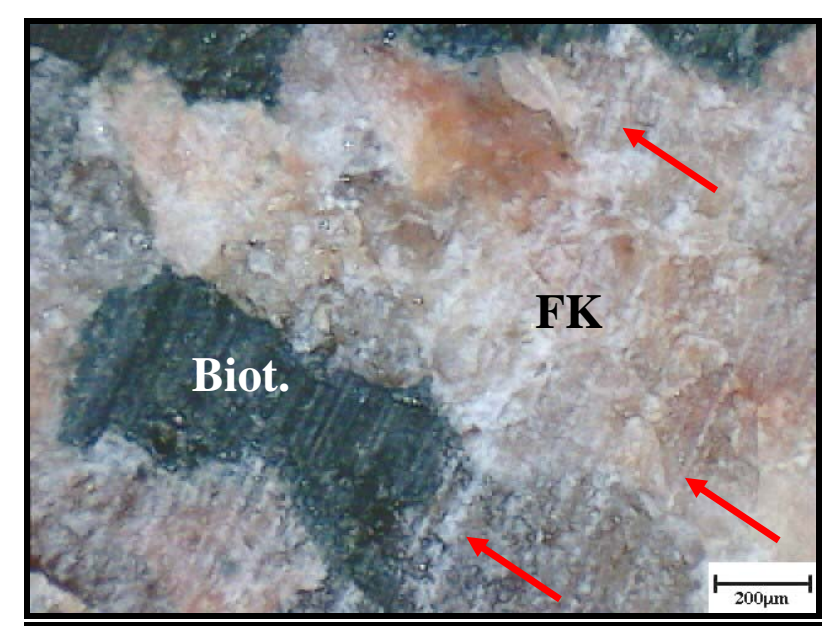

Figura 4.30 - Amostra do granito Vermelho Brasília submetido a solicitações de desgaste com abrasivo 60 mesh. Notar predominância de riscos produto da ação do abrasivo (seta vermelha).

Com exceção de dois pontos no perfil de rugosidade, o granito Cinza Castelo apresenta um $\mathrm{R}_{\max }$ na ordem dos 200 microns, diminuindo esse parâmetro praticamente $50 \%$ em relação à fase anterior (Figura 4.31). As maiores depressões são causadas por microfissuras intragrão encontradas principalmente no interior de cristais de plagioclásio e secundariamente em cristais de quartzo (Figura 4.32). 


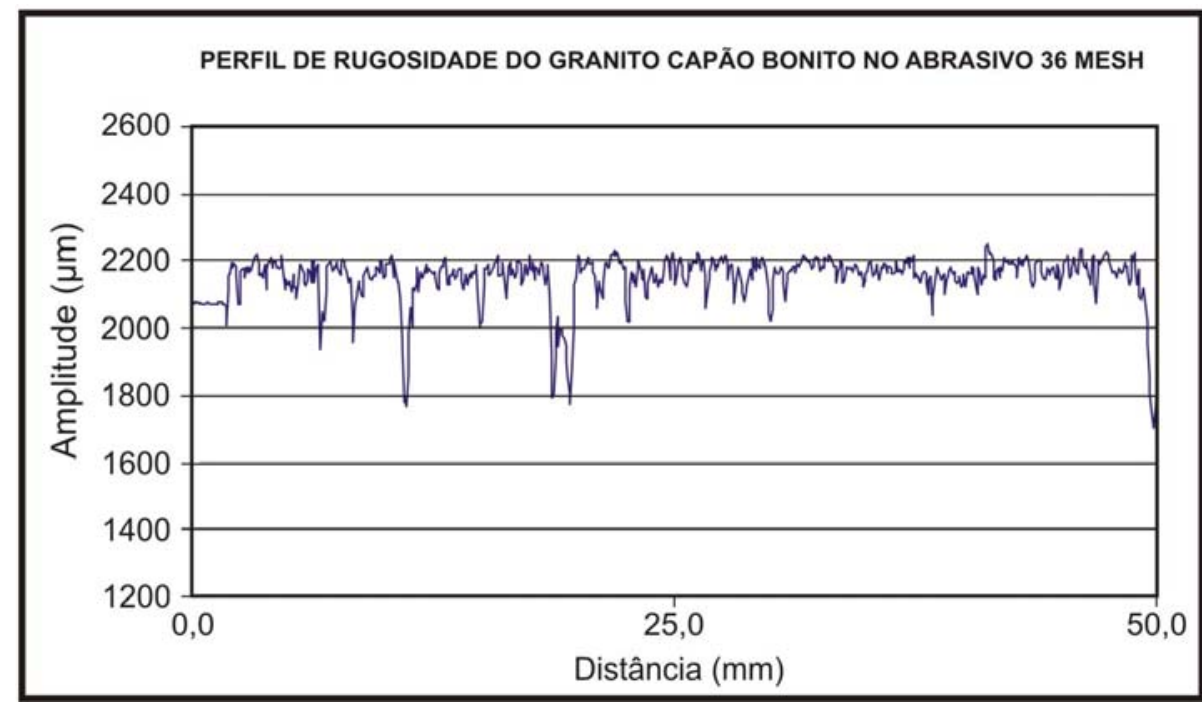

Figura 4.31 - Rugosidade do granito Cinza Castelo na terceira etapa de desgaste.

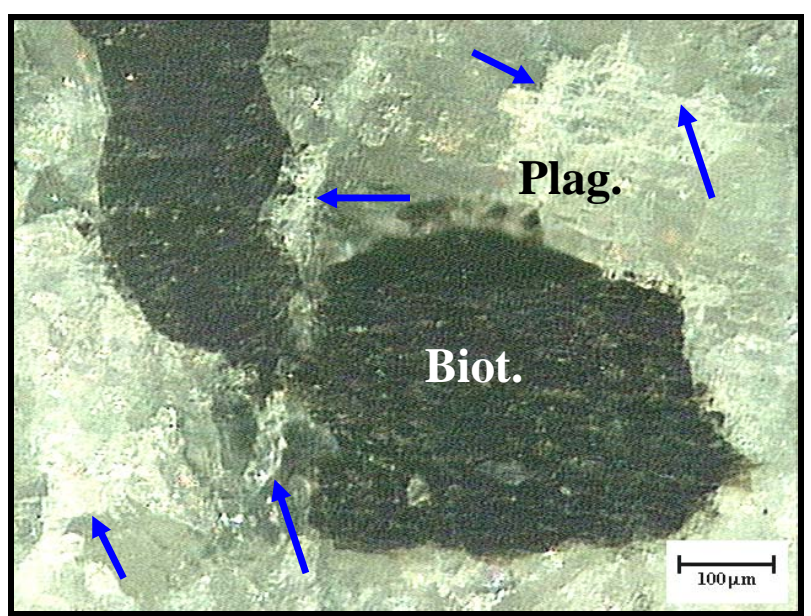

Figura 4.32 - Amostra do granito Cinza Castelo submetido a solicitações de desgaste com abrasivo 60 mesh. Notar existência de microfissuras intragrão em cristais de plagioclásio e quartzo (seta azul).

O "granito" Desert Storm apresentou um $\mathrm{R}_{\max }$ de 400 microns, diminuindo cerca de 100 microns da fase anterior. O padrão de rugosidade nesta etapa ainda reflete a grande heterogeneidade deste material, com concentração de porção com diferentes amplitudes de rugosidades, decorrente da anisotropia da rocha (Figura 4.33). Alguns picos e vales mais acentuados são também associados ao alto grau de microfissuramento (Figura 4.34). 


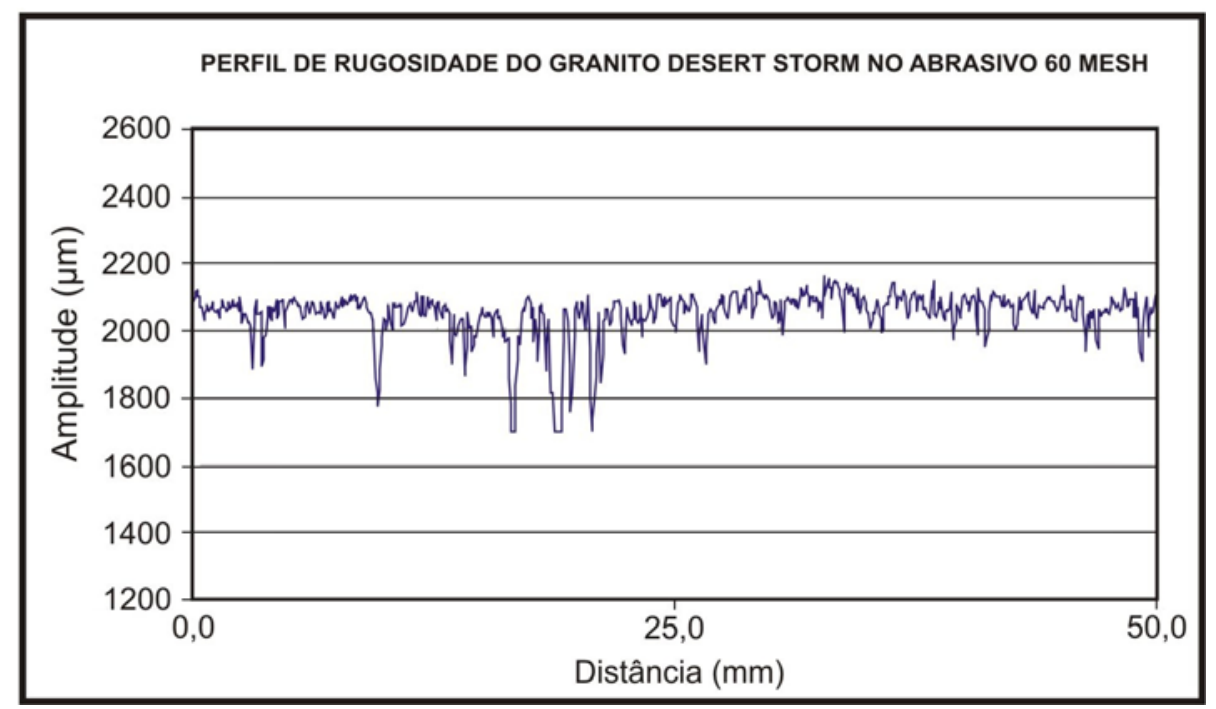

Figura 4.33 - Rugosidade do “granito” Desert Storm na terceira etapa de desgaste.

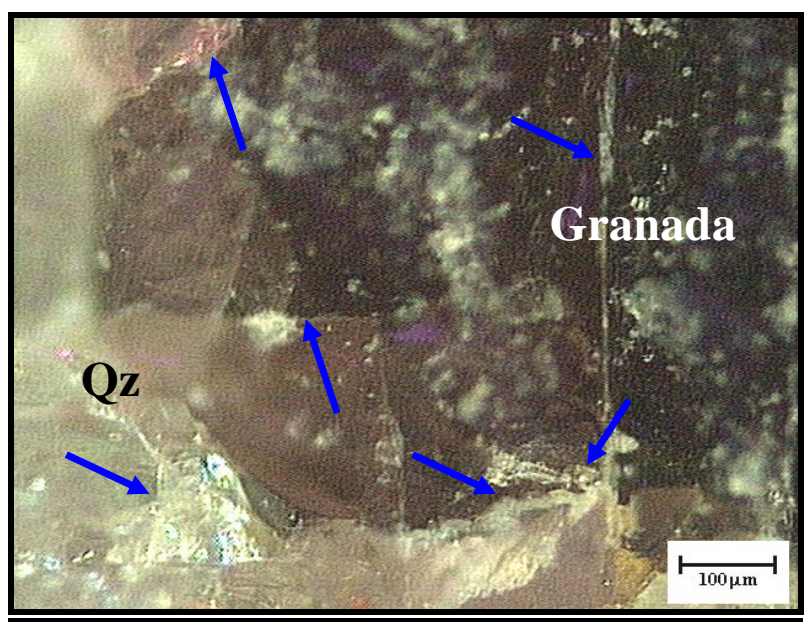

Figura 4.34 - “Granito” Desert Storm submetido a solicitações de desgaste com abrasivo 60 mesh. Notar existência grande número de microfissuras intragrão em cristais de plagioclásio e quartzo (seta azul).

Nesta etapa o "granito" Verde Labrador apresentou uma rugosidade média de 200 microns, diminuindo assim praticamente metade da rugosidade encontrada na segunda etapa de desgaste (\#36 mesh) (Figura 4.35). É possível notar também um padrão mais contínuo do perfil de rugosidade, o que denota uma maior planicidade da superfície. Nesta fase praticamente desaparecem as microfissuras, que eram facilmente encontrados nas etapas anteriores (Figura 4.36). 


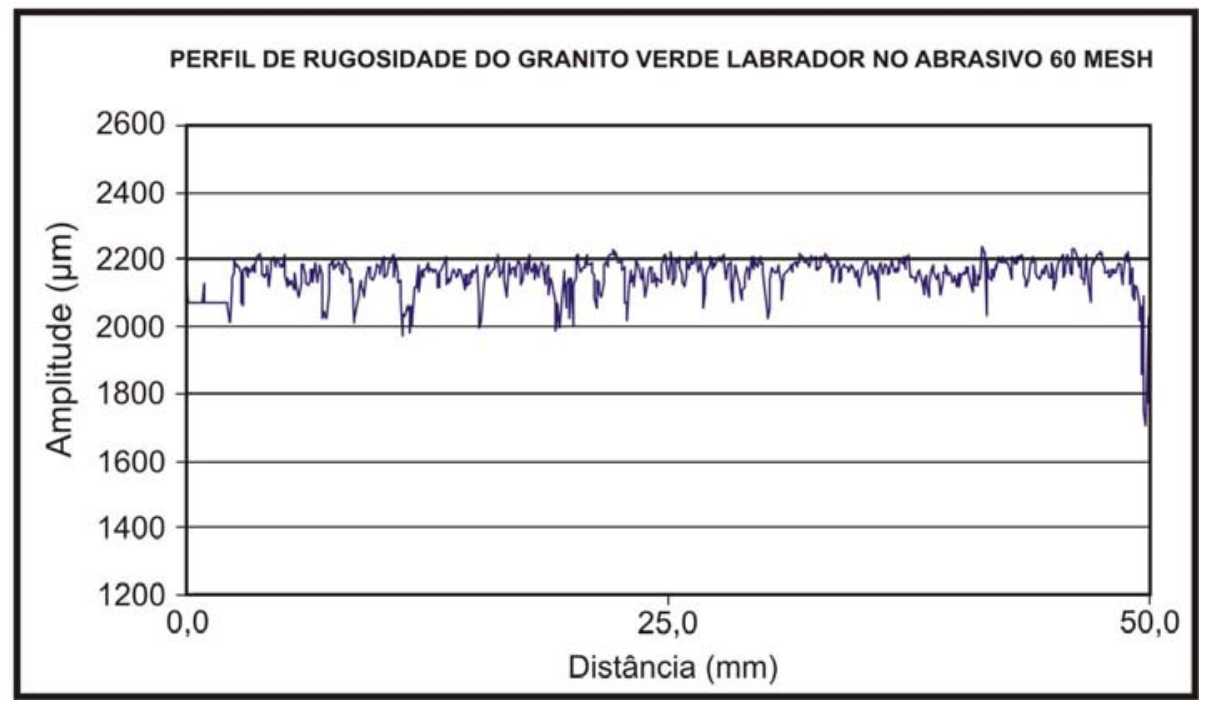

Figura 4.35 - Rugosidade do “granito” Verde Labrador na terceira etapa de desgaste.

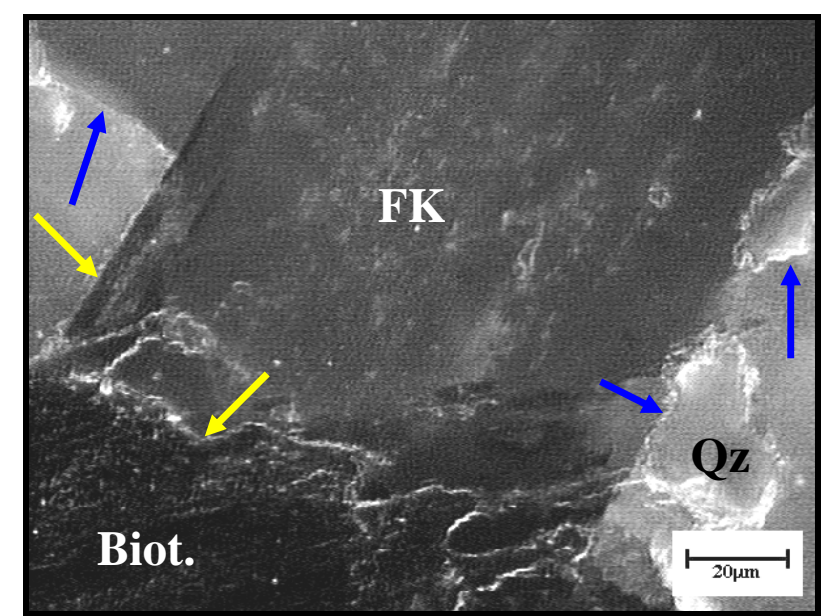

Figura 4.36 - “Granito” Verde Labrador submetido a solicitações de desgaste com abrasivo 60 mesh. As principais descontinuidades são uma pequena quantidade de microfissuras intragrão (seta azul) e intergrão (seta amarela).

Até esta etapa, os perfis de rugosidade do granito Vermelho Capão Bonito, sempre apresentaram os maiores valores de $\mathrm{R}_{\max }$. Tal característica é comprovada pelos resultados do brilho dos corpos-de-prova submetidos à medição da rugosidade. Nesta fase, este material apresentou $\mathrm{R}_{\max }$ de quase 900 microns (Figura 4.37), o que sugere a geração de microfissuras ao longo do processo de polimento, possivelmente geradas por uma menor resistência desta rocha às cargas impostas pelo satélite de polimento (Figura 4.38). 


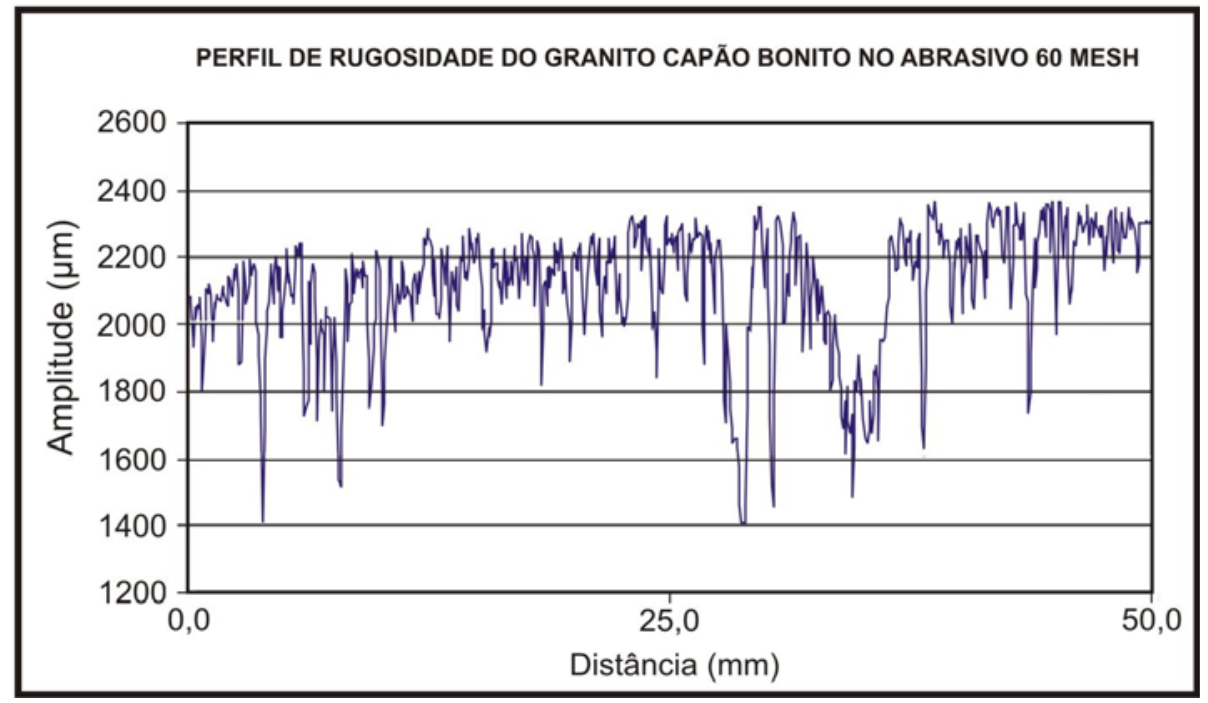

Figura 4.37 - Rugosidade do granito Vermelho Capão Bonito na terceira etapa de desgaste.

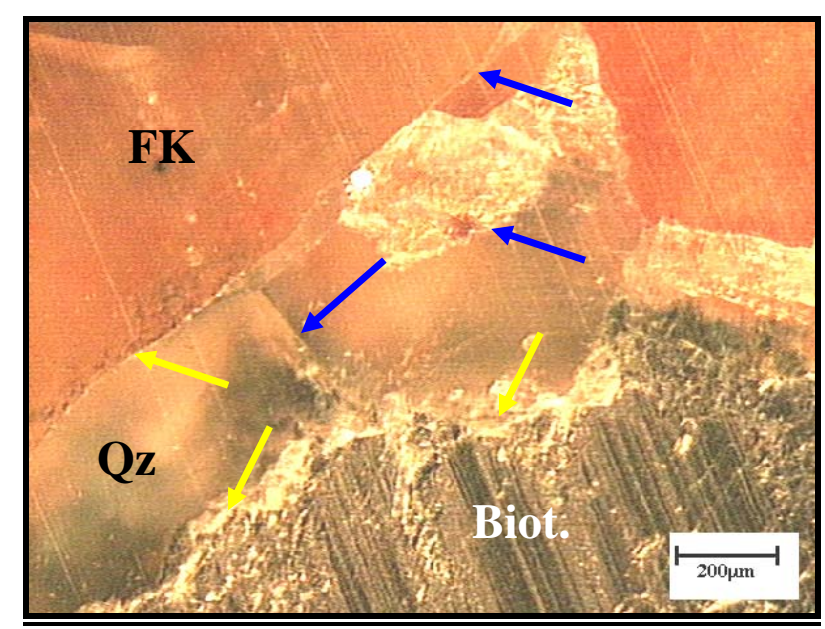

Figura 4.38 - Granito Vermelho Capão Bonito submetido a solicitações de desgaste com abrasivo 60 mesh. Grande ocorrência de microfissuras intragrão (seta azul) e intergrão (seta amarela).

Nas etapas posteriores é possível notar a sensível diminuição do porte dos riscos impostos pelo abrasivo na superfície da rocha.

\subsubsection{QUARTA ETAPA (\#120 MESH)}

De modo empírico, a Indústria da Pedra definiu esta etapa como sendo o momento ideal para a resinagem das chapas. Visualizando o perfil de rugosidade do "granito" Preto Indiano (Figura 4.39) é possível perceber que nesta fase ocorre, pela primeira vez, uma separação entre a rugosidade da superfície mineral propriamente dita e os picos e vales mais 
acentuados que representam contatos entre minerais ou microfissuras. Esta boa separação se deve principalmente ao fato de que as bandas composicionais que ocorrem neste material respondem às solicitações impostas pelo processo de polimento de modo diferente, bem como a diminuição da granulometria do abrasivo.

Com a individualização destas duas rugosidades, qualquer análise ou enfoque que seja dado na interpretação dos dados de rugosidade, obrigatoriamente tem que considerar ambas como irregularidades que diminuem a planicidade de uma superfície, interferindo assim, no brilho final da rocha. Porém, é importante lembrar que o primeiro tipo de rugosidade, mais tênue e contida na superfície mineral, está mais relacionado ao processo de polimento e que a outra, com $\mathrm{R}_{\max }$ mais elevados, mais se relaciona às características genéticas da rocha.

A partir deste ponto, quando se quiser aludir a rugosidade da superfície de um mineral será utilizado o termo "Rugosidade Mineral” e quando a referência for feita a rugosidade maior, produto dos contatos entre os minerais, será usado o termo "Rugosidade de Contatos”.

Nesta fase ocorre uma sensível diminuição dos valores de $\mathrm{R}_{\max }$ para a rugosidade mineral, com valores que variam entre os 150 microns, enquanto que a rugosidade de contatos chega até os 1000 microns para o "granito" Preto Indiano. 


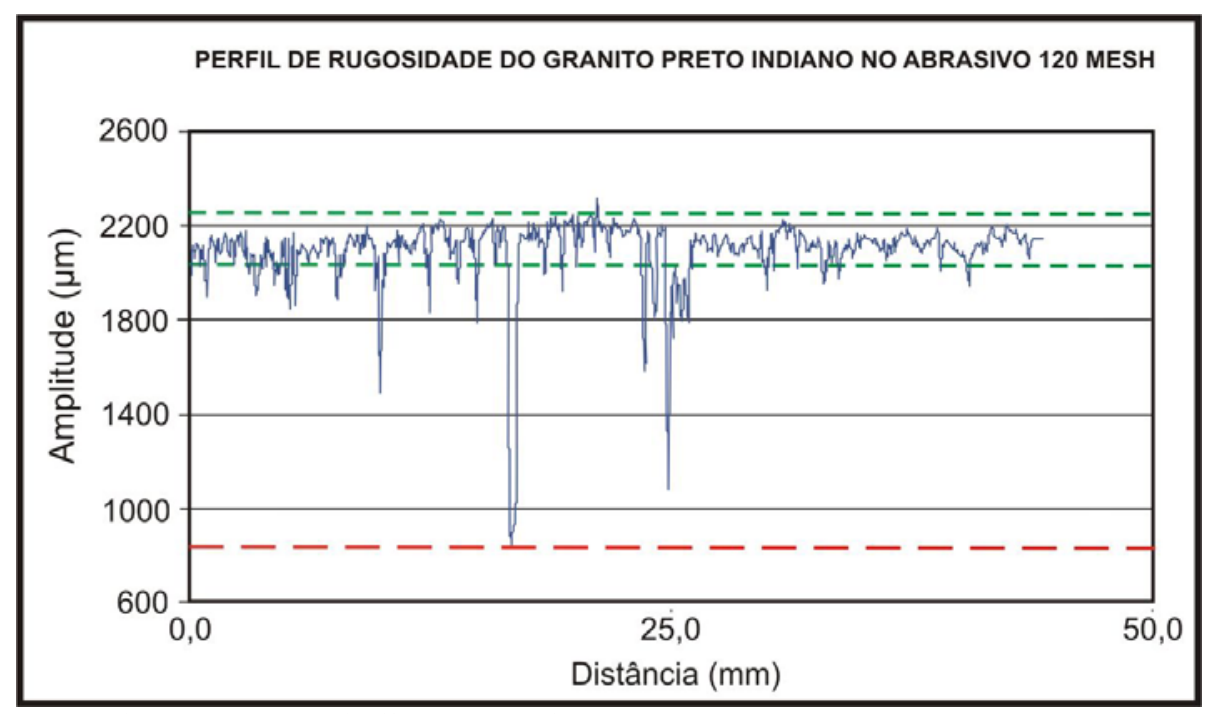

Figura 4.39 - Rugosidade do "granito" Preto Indiano na quarta etapa de desgaste, mostrando a separação dos dois tipos de irregularidades: Rugosidade mineral (tracejado verde) e Rugosidade de contatos (tracejado vermelho).

$\mathrm{Na}$ foto a seguir, se nota uma real diminuição do tamanho dos sulcos feitos pelo abrasivo. Porém a porção mais mole começa a sofrer um desplacamento de lamelas de mica o que pode gerar um aumento na rugosidade de contatos (Figura 4.40). Esse desplacamento pode ter sido gerado por um aumento na pressão do cabeçote da politriz e pode justificar uma depressão anômala no perfil de rugosidade de materiais moles.

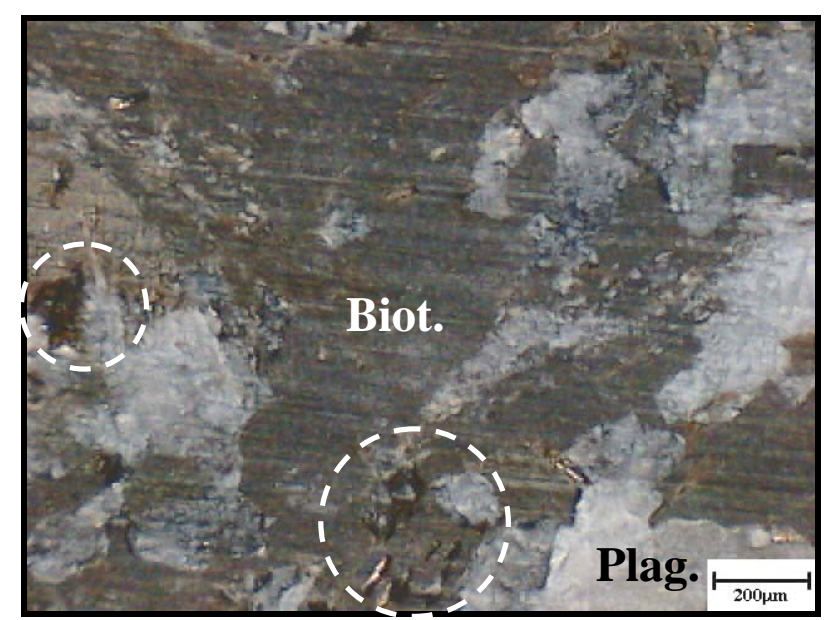

Figura 4.40 - Amostra do "granito" Preto Indiano submetido a solicitações de desgaste com abrasivo 120 mesh. Notar desprendimento de lamelas de biotita (tracejado branco).

Nesta fase, o granito Vermelho Brasília apresenta um $\mathrm{R}_{\max }$ de, aproximadamente, 200 microns (Figura 4.41). Esta rocha, por apresentar na sua composição mineralógica essencialmente quartzo e feldspato potássico, com pouca quantidade de mica, apresenta um 
padrão bem mais constante no perfil de rugosidade. Aliado às características mineralógicas, seu caráter isotrópico ajuda para que tal constância se verifique.

Um fator que passa a ter mais participação para a geração de irregularidades é a existência de planos de clivagem mineral. No caso dos feldspatos potássicos presentes nesta rocha, tais planos muitas vezes, definem os maiores sulcos presentes na rocha, visto que, os riscos deixados pelos abrasivos, a partir daqui, serão menores do que tais feições minerais (Figura 4.42).

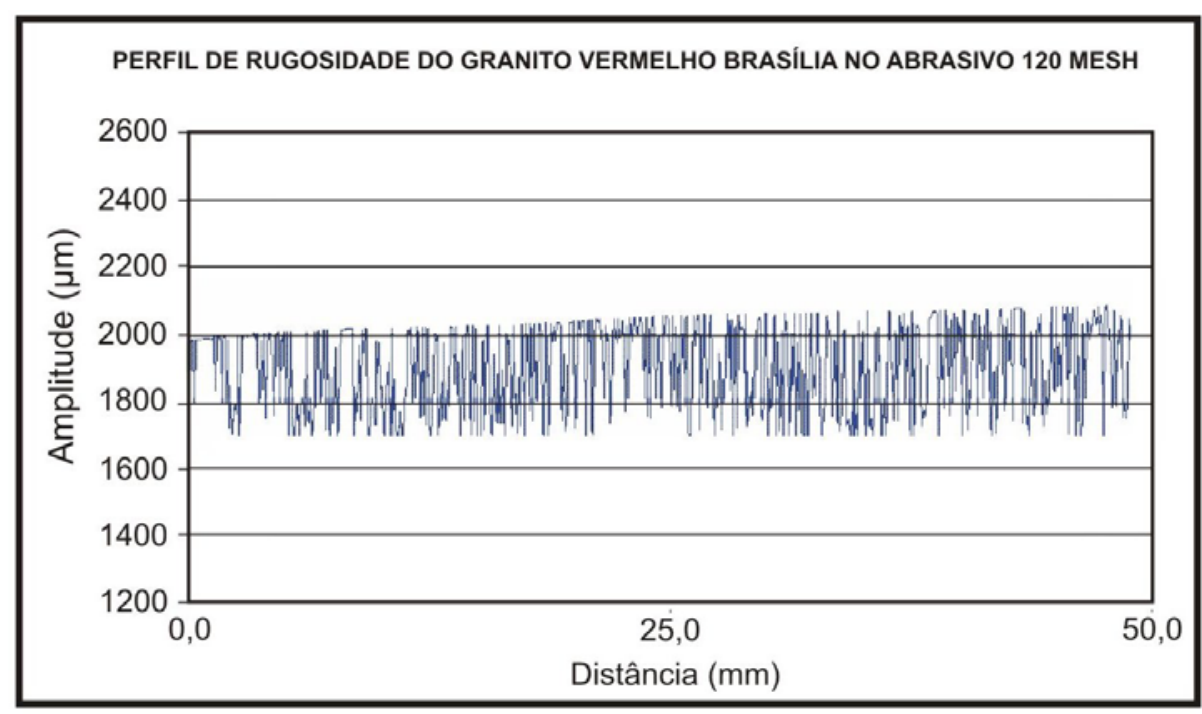

Figura 4.41 - Rugosidade do granito Vermelho Brasília na quarta etapa de desgaste.

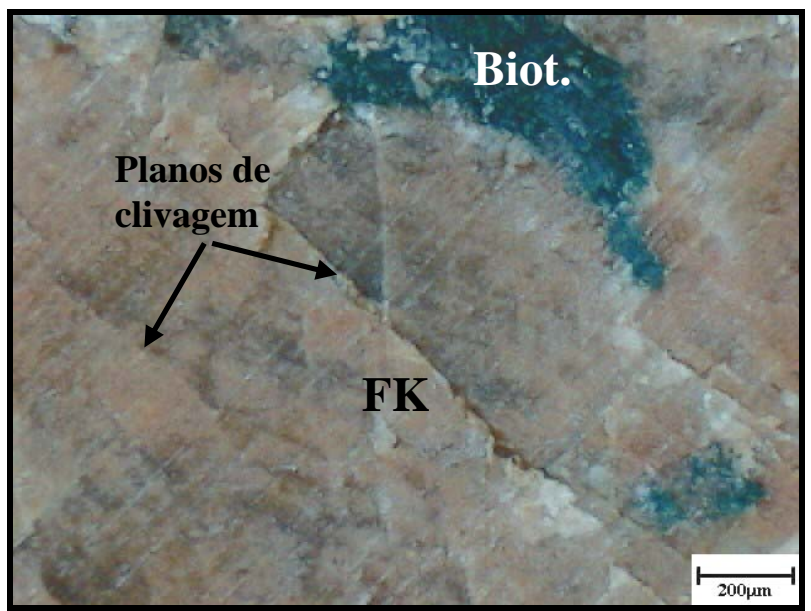

Figura 4.42 - Amostra do granito Vermelho Brasília submetido a solicitações de desgaste com abrasivo 120 mesh. Notar o maior porte do sulco de um dos planos de clivagem do mineral em relação aos riscos feito pelo abrasivo. 
O granito Cinza Castelo apresentou nesta etapa uma diminuição geral de rugosidade ao longo de todo o perfil, ficando a maior parte situada a valores menores que 200 microns (Figura 4.43). As principais descontinuidades são microfissuras intragrão nos cristais de plagioclásio (Figura 4.44).

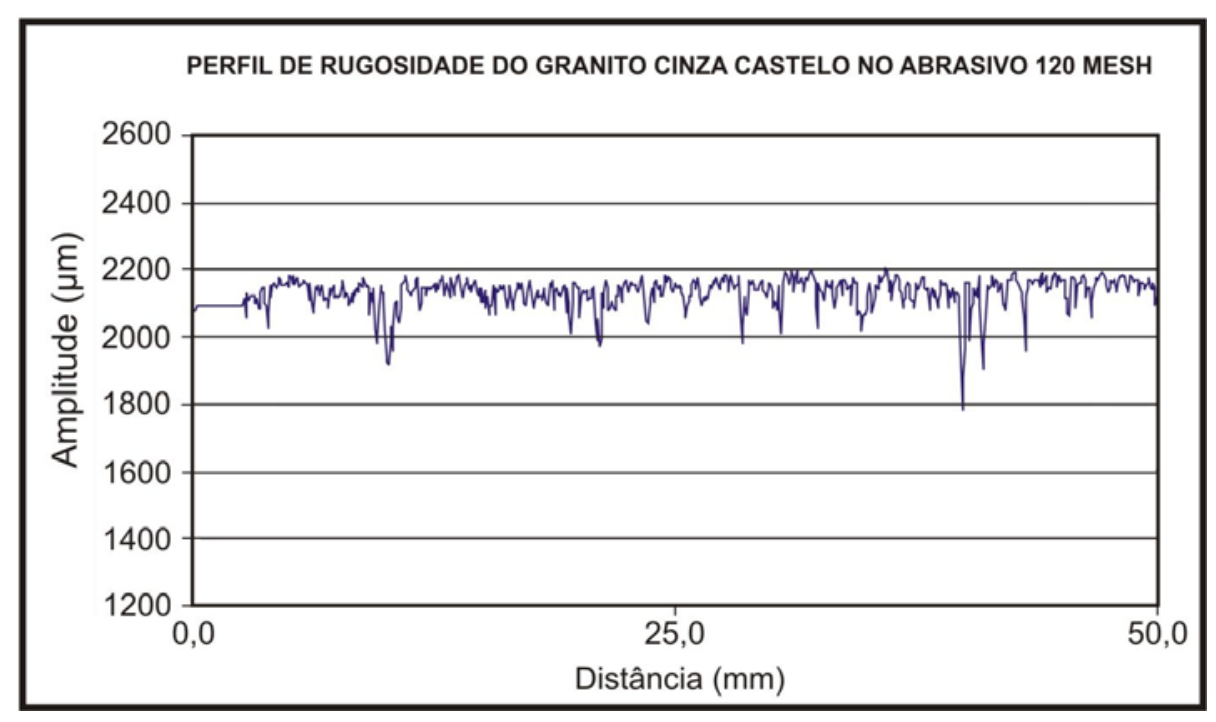

Figura 4.43 - Rugosidade do granito Cinza Castelo na quarta etapa de desgaste.

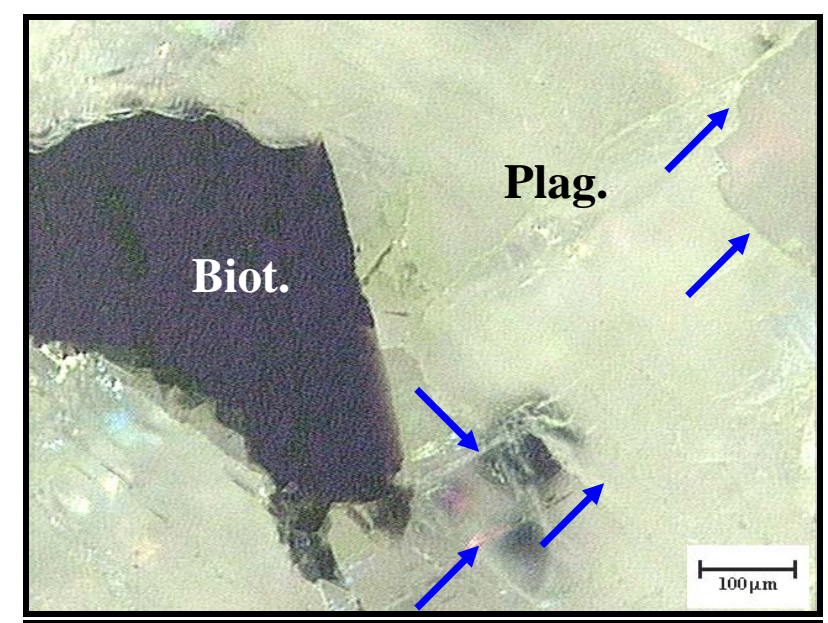

Figura 4.44 - Granito Cinza Castelo submetido a solicitações de desgaste com abrasivo 120 mesh. Notar ocorrência de microfissuras intragrão (seta azul).

Nesta fase, a rugosidade mineral do "granito" Desert Storm apresentou uma sensível diminuição, se comparada com a etapa anterior. Porém, algumas depressões com $\mathrm{R}_{\max }$ chegando a 500 microns sugerem o desenvolvimento de trincas mais pronunciadas neste 
material na quarta etapa de desgaste (Figura 4.45). Tais feições podem ter sido produto do desenvolvimento de trincas intragrão ao longo desta etapa de polimento (Figura 4.46).

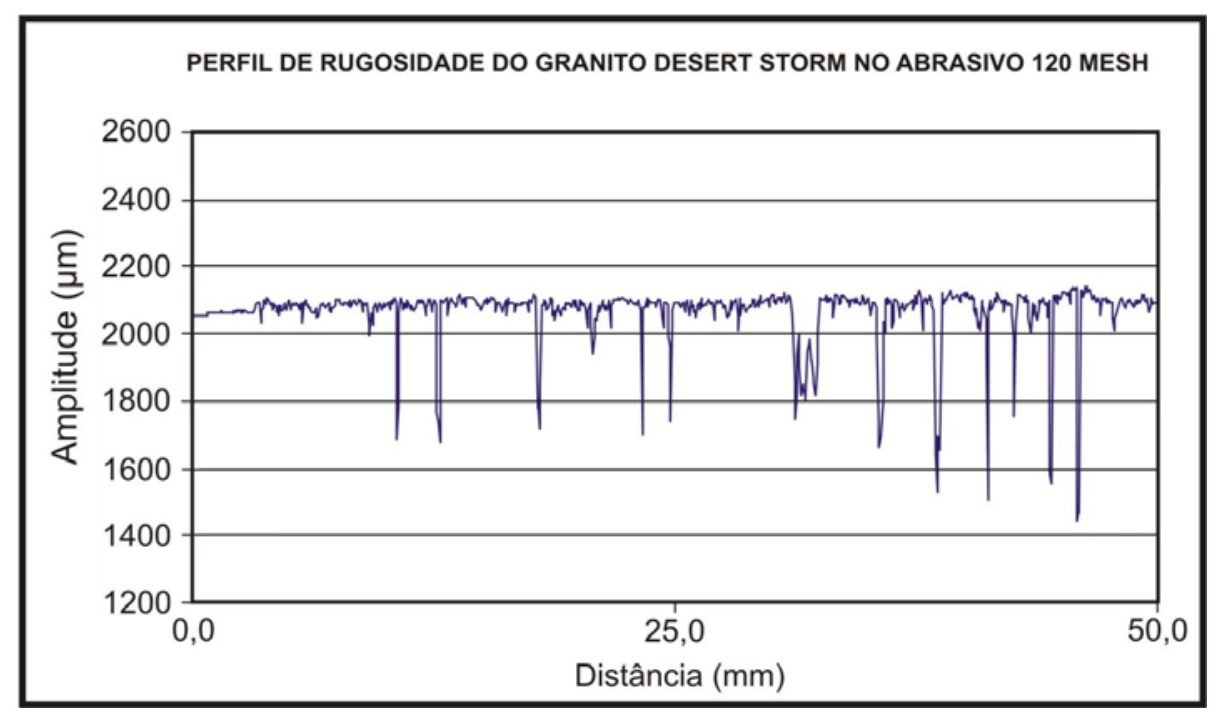

Figura 4.45 - Rugosidade do “granito” Desert Storm na quarta etapa de desgaste.

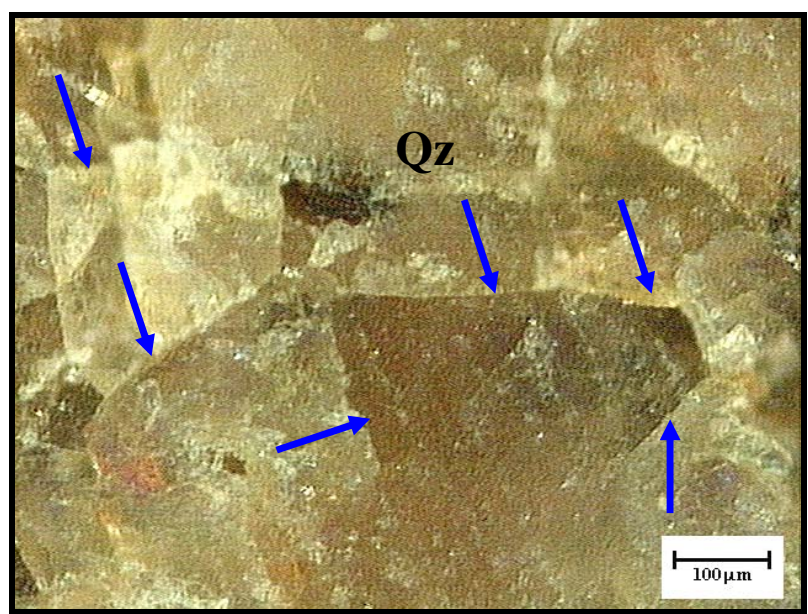

Figura 4.46 - “Granito” Desert Storm submetido a solicitações de desgaste com abrasivo 120 mesh. Notar ocorrência de microfissuras intragrão (seta azul).

O "granito" Verde Labrador apresentou uma sensível diminuição nas amplitudes do perfil de rugosidade, sendo que o $\mathrm{R}_{\max }$ encontrado nesta etapa foi de 200 microns. Porém, de modo geral, o perfil apresentou amplitudes na casa dos 50 microns (Figura 4.47). As principais depressões ficaram por conta de riscos causados pelo abrasivo e por microfissuras intragrão (Figura 4.48). 


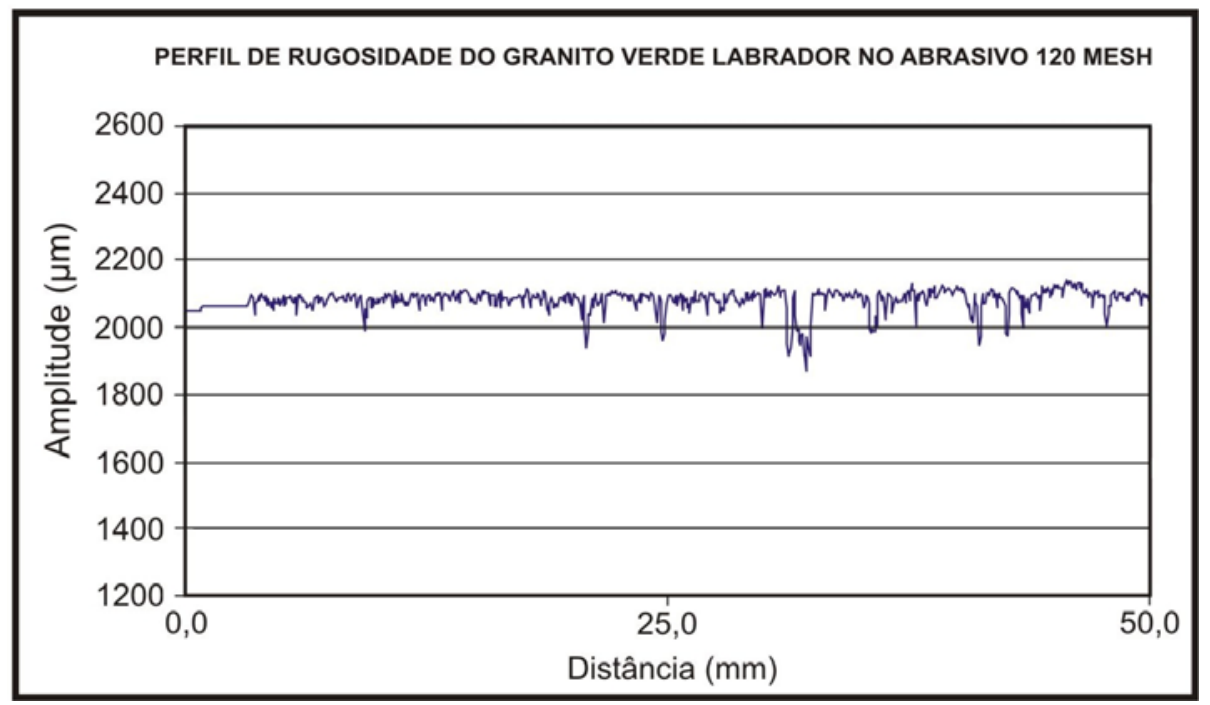

Figura 4.47 - Rugosidade do “granito” Verde Lavrador na quarta etapa de desgaste.

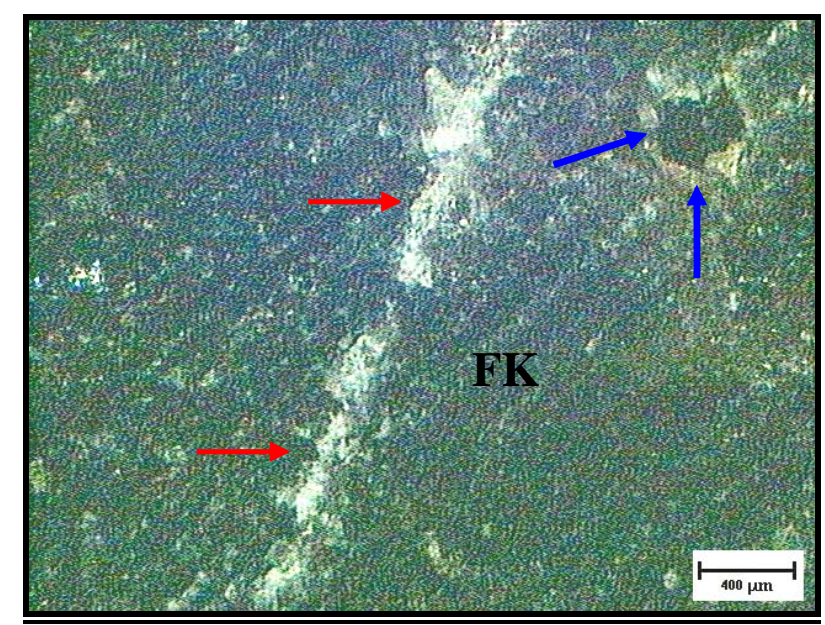

Figura 4.48 - Amostra do "granito" Verde Labrador submetido a solicitações de desgaste com abrasivo 120 mesh. Notar a presença dos riscos gerados pelo abrasivo (seta vermelha) e por microfissuras intragrão (seta azul).

Se comparada com a etapa anterior, o perfil de rugosidade desta rocha apresentou uma grande diminuição, embora ainda apresente a maior dentre as rochas estudadas. $O R_{\max }$ permaneceu na casa dos 900 microns, mas o perfil como um todo se tornou mais homogêneo (Figura 4.49). As maiores depressões foram registradas em microfissuras intergrão e intragrão (Figura 4.50). 


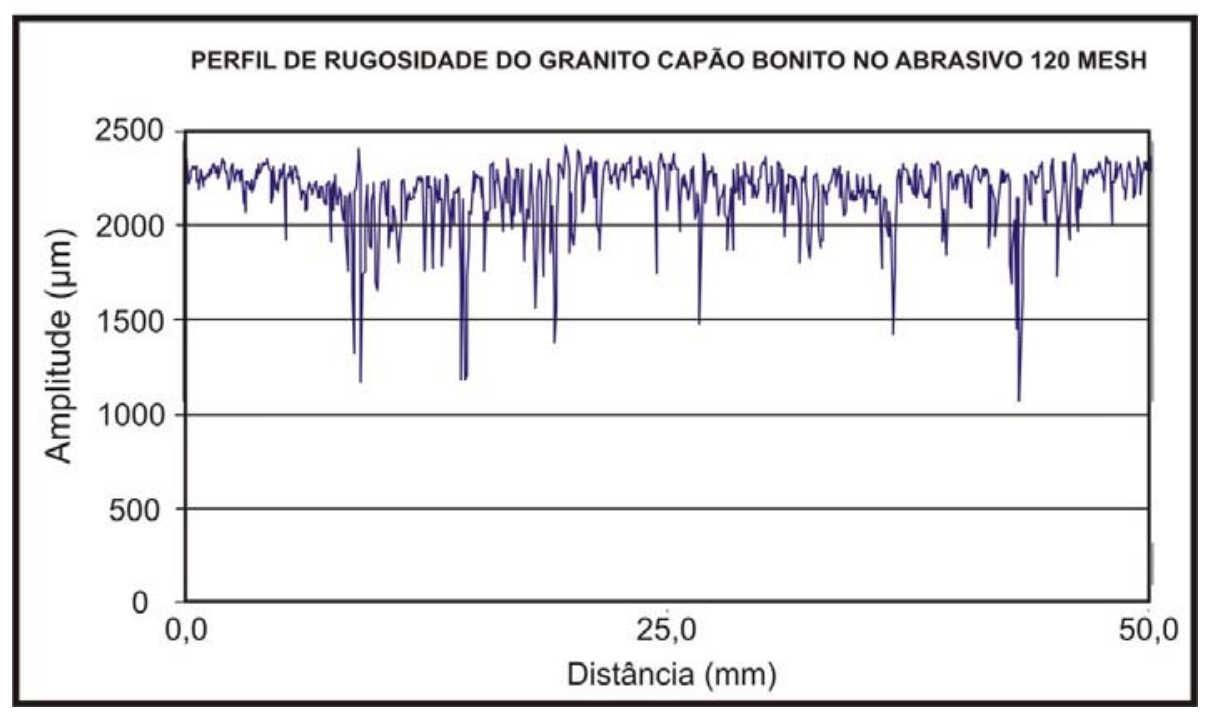

Figura 4.49 - Rugosidade do granito Vermelho Capão Bonito na quarta etapa de desgaste.

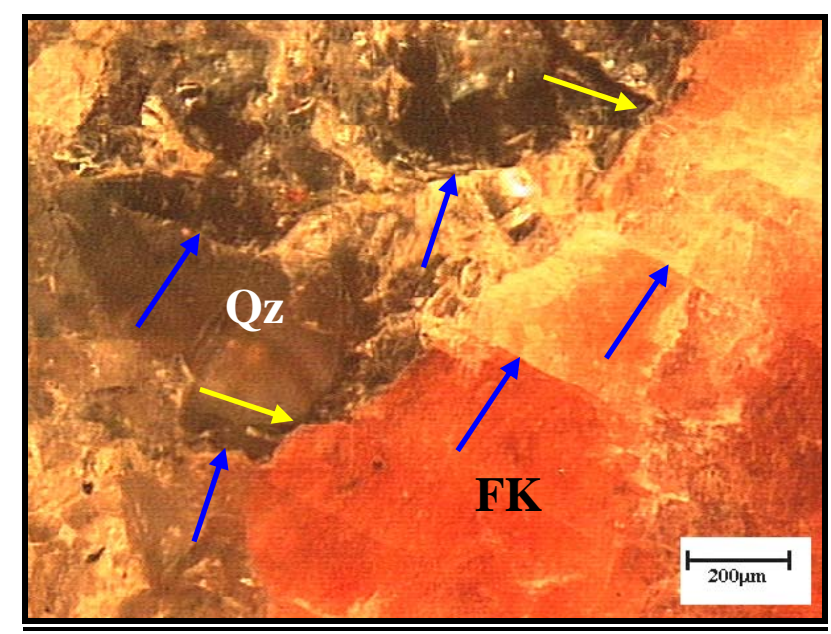

Figura 4.50 - Granito Vermelho Capão Bonito submetido a solicitações de desgaste com abrasivo 120 mesh. Grande ocorrência de microfissuras intragrão (seta azul) e intergrão (seta amarela).

\subsubsection{QUINTA ETAPA (\#220 MESH)}

$\mathrm{Na}$ indústria, depois da etapa de levigamento, a rocha volta a ser submetida ao abrasivo 120 mesh. Só depois então é que se processa a etapa subseqüente, de 220 mesh. Nesta fase, o "granito" Preto Indiano apresentou uma rugosidade mineral em torno dos 200 microns, enquanto que a rugosidade de contatos atingiu os 420 microns (Figura 4.51). 


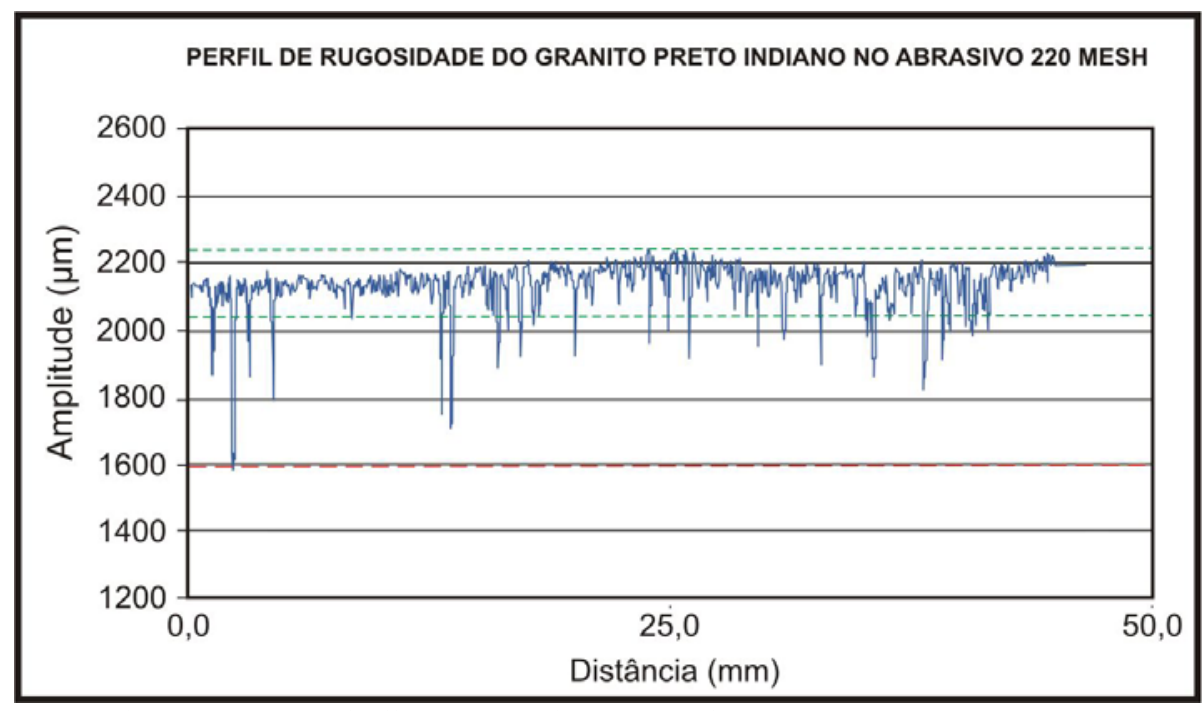

Figura 4.51 - Rugosidade do "granito" Preto Indiano na quinta etapa de desgaste, mostrando a separação dos dois tipos de irregularidades: Rugosidade mineral (tracejado verde) e Rugosidade de contatos (tracejado vermelho).

$\mathrm{Na}$ amostra ensaiada é possível verificar, em alguns locais, cristais de granada apresentando uma superfície desgastada com trincas, configurando pontos potenciais para uma desagregação (Figura 4.52). Nas situações de brilho final (última fase de polimento) este mineral quase sempre se apresenta como um dos principais responsáveis pelas irregularidades de maior porte na chapa.

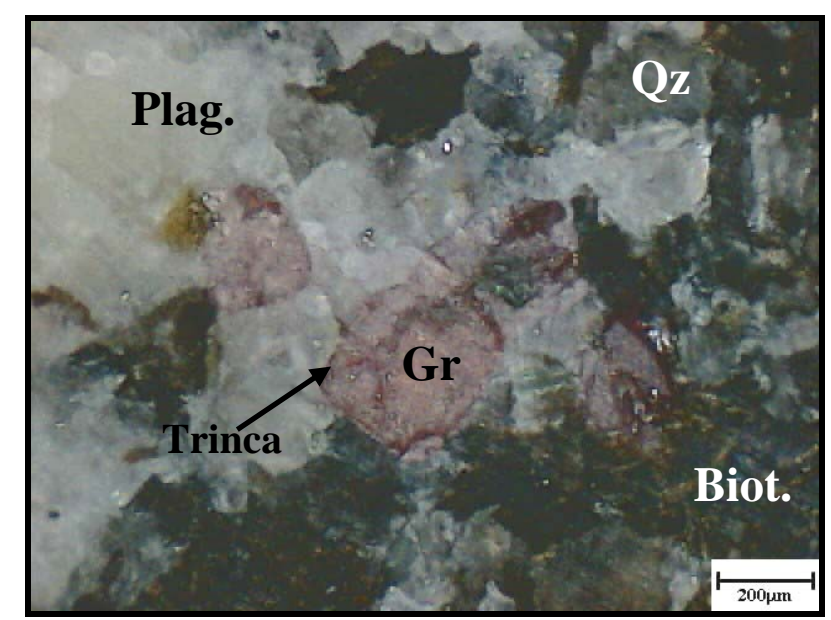

Figura 4.52 - Amostra do "granito" Preto Indiano submetido a solicitações de desgaste com abrasivo 220 mesh. Notar a presença de cristais de granada com trincas no seu interior.

O granito Vermelho Brasília apresenta valores de $\mathrm{R}_{\max }$ na ordem de 150 microns. Em algumas porções do gráfico é possível notar a da separação dos dois tipos de rugosidade (Figura 4.53). 


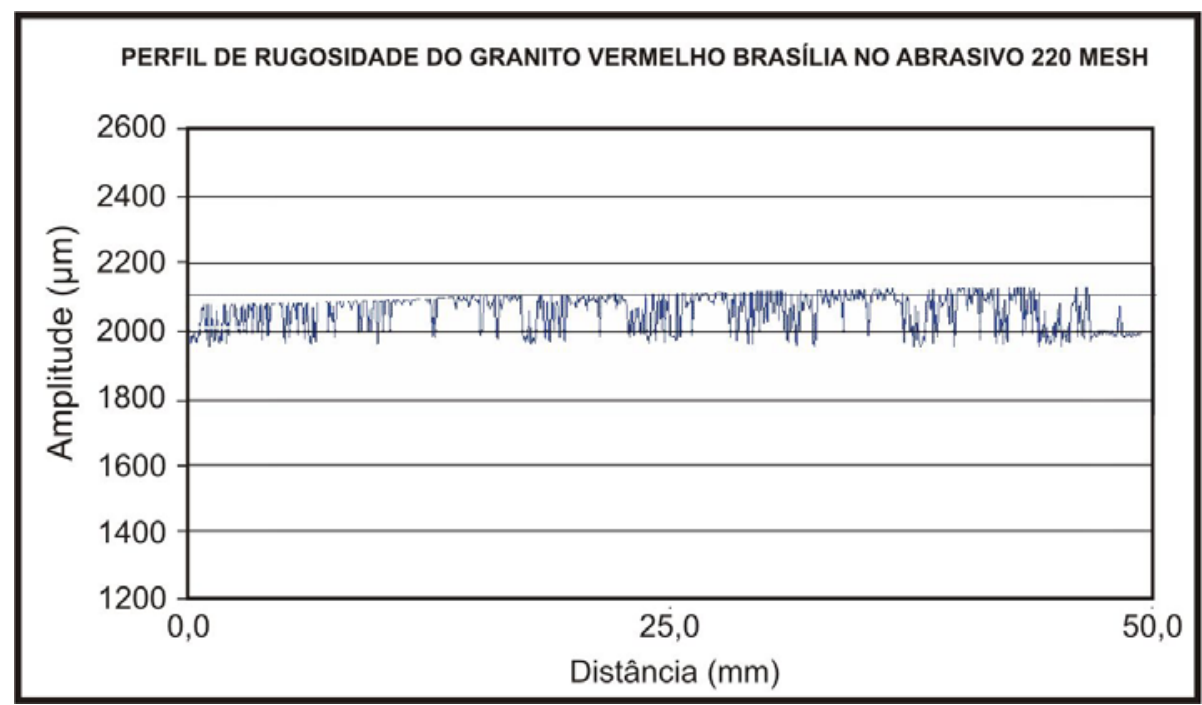

Figura 4.53 - Rugosidade do granito Vermelho Brasília na quinta etapa de desgaste.

Nesta fase, como na anterior, as maiores irregularidades da superfície estão associadas aos planos de clivagem do feldspato potássico (Figura 4.54).

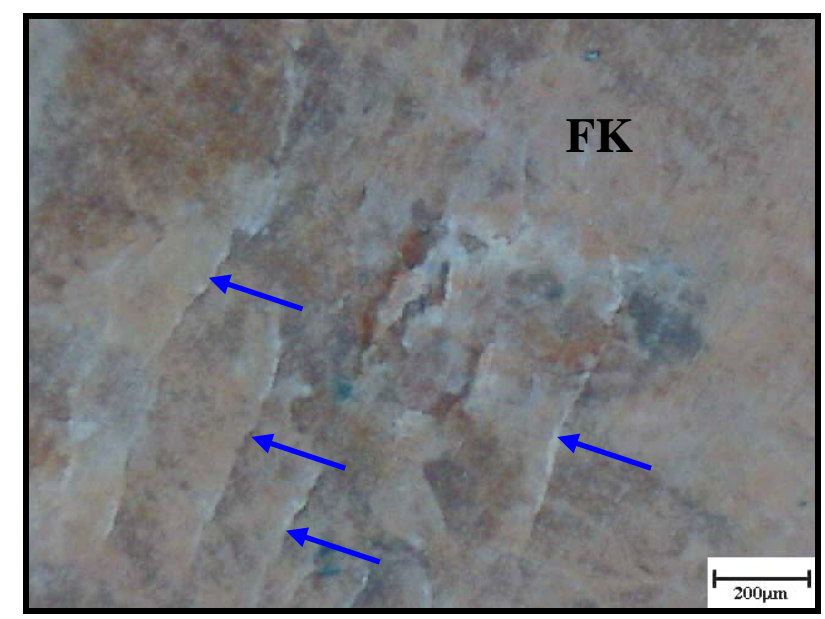

Figura 4.54 - Amostra do granito Vermelho Brasília submetido a solicitações de desgaste com abrasivo 220 mesh. Notar a presença de trincas associadas aos planos de clivagem do feldspato potássico (seta azul).

Na quinta etapa de desgaste, o granito Cinza Castelo apresentou uma diminuição da rugosidade em relação a etapa anterior ao longo do todo o perfil, o que reflete a homogeneidade desta rocha. Os valores de rugosidade ficaram na casa dos 100 microns, mostrando poucos pontos com $\mathrm{R}_{\max }$ de 200 microns aproximadamente (Figura 4.55). Os principais pontos de geração de vales mais acentuados de rugosidade ficaram por conta de riscos causados pelo abrasivo e por microfissuras intragrão (Figura 4.56). 


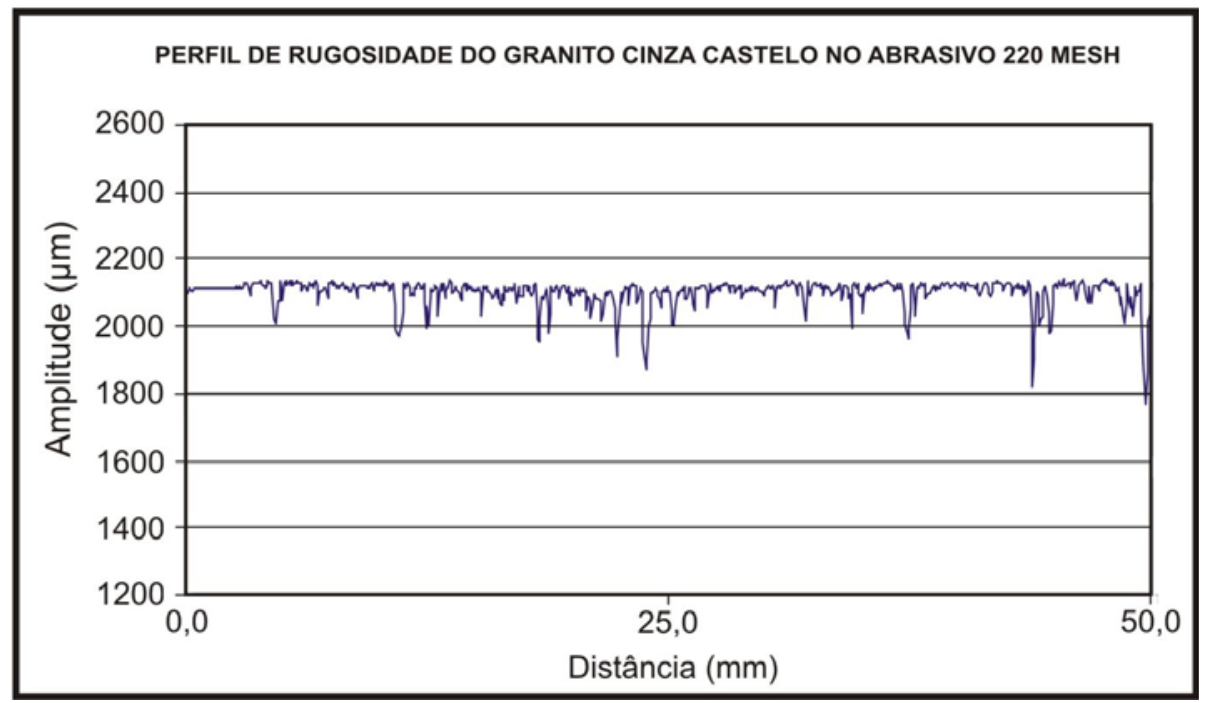

Figura 4.55 - Rugosidade do granito Vermelho Brasília na quinta etapa de desgaste.

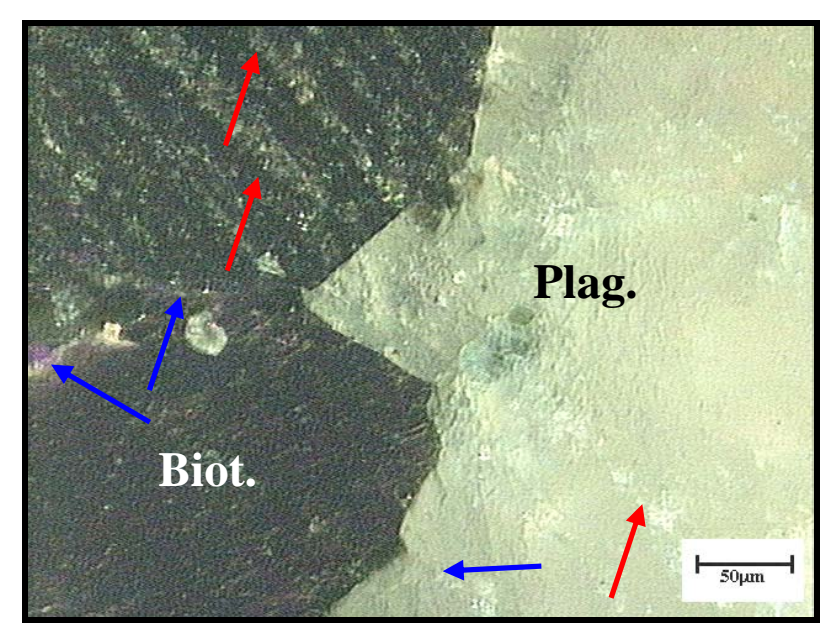

Figura 4.56 - Amostra do granito Cinza Castelo submetido a solicitações de desgaste com abrasivo 220 mesh. Notar a presença de microfissuras intragrão (seta azul) e riscos oriundos do abrasivo (seta vermelha).

O "granito” Desert Storm mostrou uma sensível diminuição da rugosidade na quinta etapa de desgaste, se comparada à fase anterior. A grande incidência de rugosidade de contato verificada na fase anterior não se repetiu nesta (Figura 4.57). As principais descontinuidades encontradas foram devido a microfissuras intragrãos, porém em menor quantidade que na etapa anterior (Figura 4.58). 


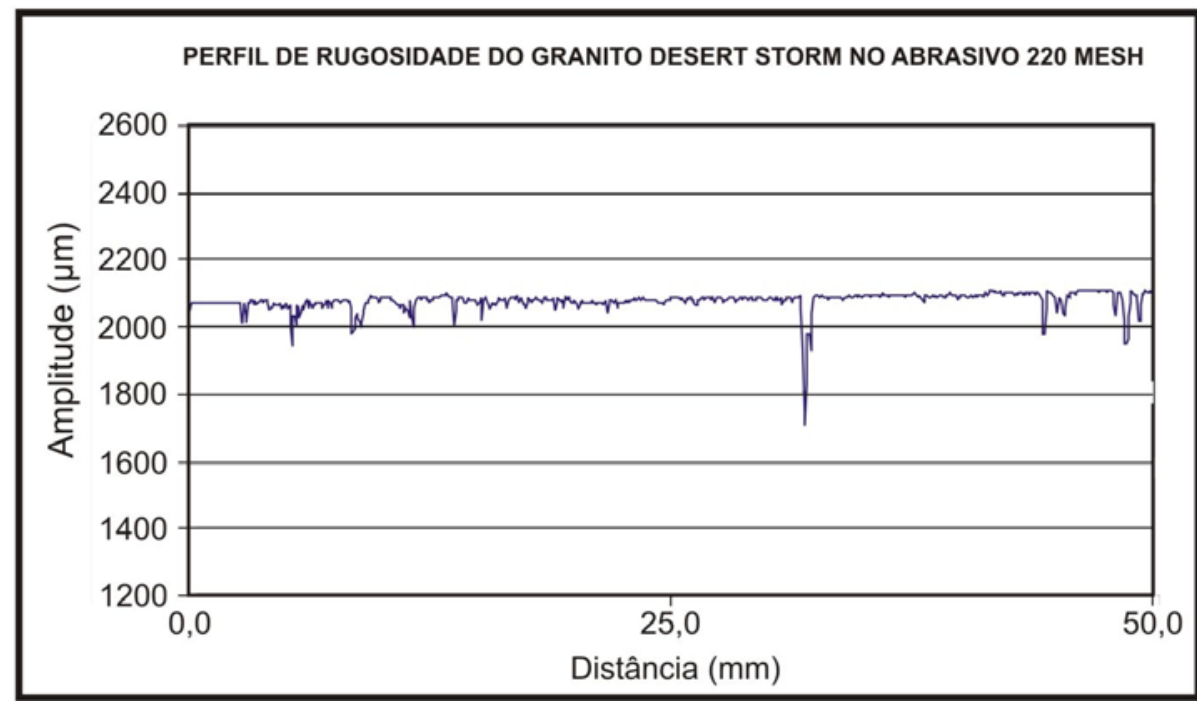

Figura 4.57 - Rugosidade do “granito” Desert Storm na quinta etapa de desgaste.

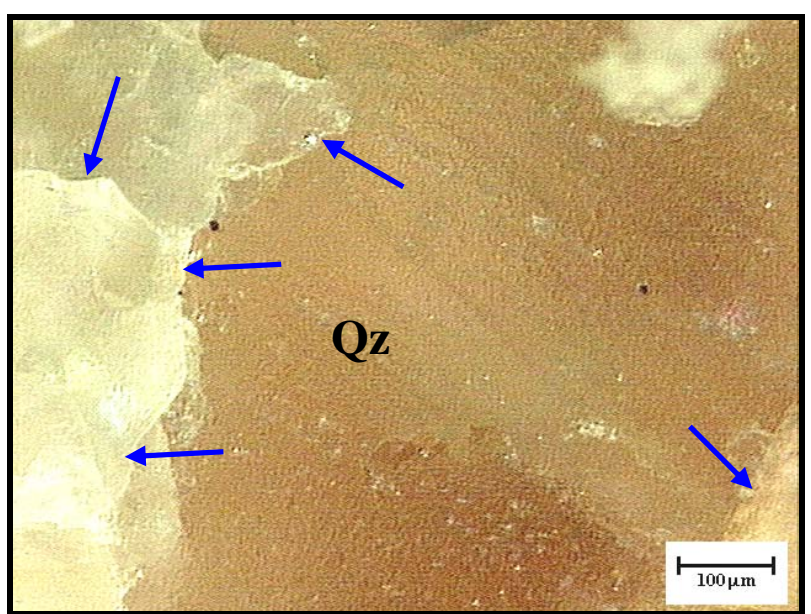

Figura 4.58 - Amostra do “granito” Desert Storm submetido a solicitações de desgaste com abrasivo 220 mesh. Notar a presença de microfissuras intragrão (seta azul).

O "granito" Verde Labrador mostra nesta fase um perfil de rugosidade com valores menores que 50 microns (Figura 4.59). A maior homogeneidade desta rocha é refletida neste e nos perfis posteriores até a etapa de lustro. A principais descontinuidades são representadas por microfissuras intragrão de pequeno porte e por riscos deixados pelo abrasivo (Figura 4.60). 


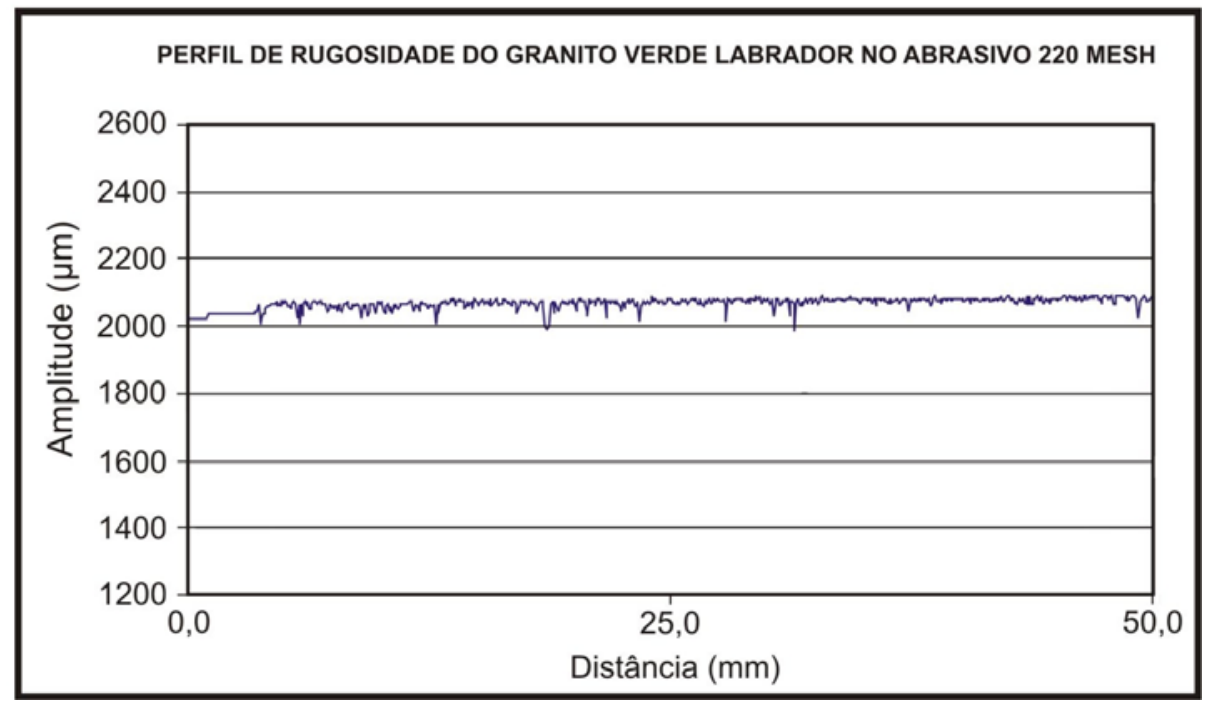

Figura 4.59 - Rugosidade do “granito” Verde Labrador na quinta etapa de desgaste.

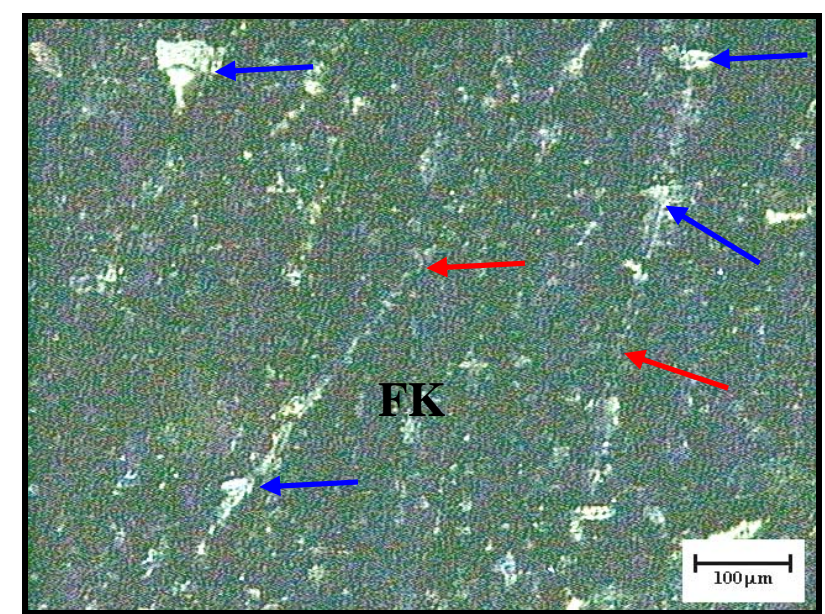

Figura 4.60 - Amostra do "granito" Verde Labrador submetido a solicitações de desgaste com abrasivo 220 mesh. Notar a presença de microfissuras intragrão (seta azul) e riscos deixados pelo abrasivo (seta vermelha).

Na quinta fase de desgaste o granito Vermelho Capão Bonito continua apresentando os maiores valores de rugosidade entre as seis rochas estudadas. Os valores de $\mathrm{R}_{\max }$ se mantemse na faixa dos 900 mesh (Figura 4.61). As principais fontes dessa alta rugosidade são os riscos deixados pelo abrasivo e por microfissuras intragrão (Figura 4.62). 


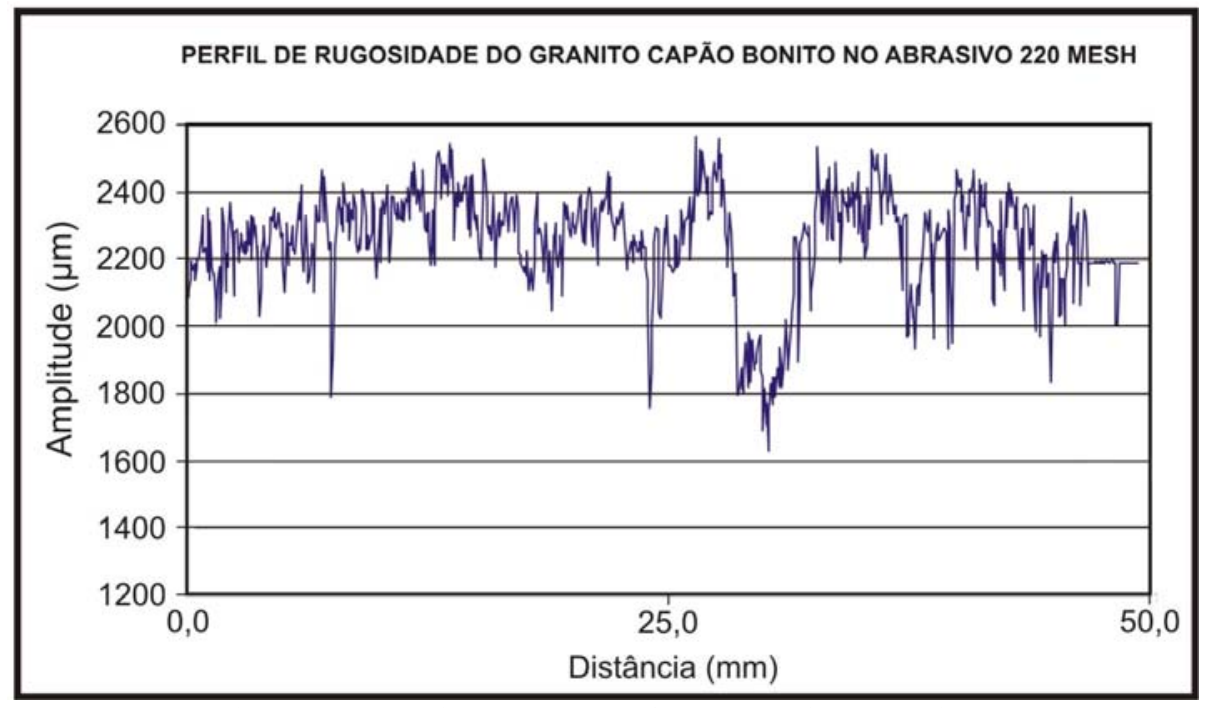

Figura 4.61 - Rugosidade do granito Vermelho Capão Bonito na quinta etapa de desgaste.

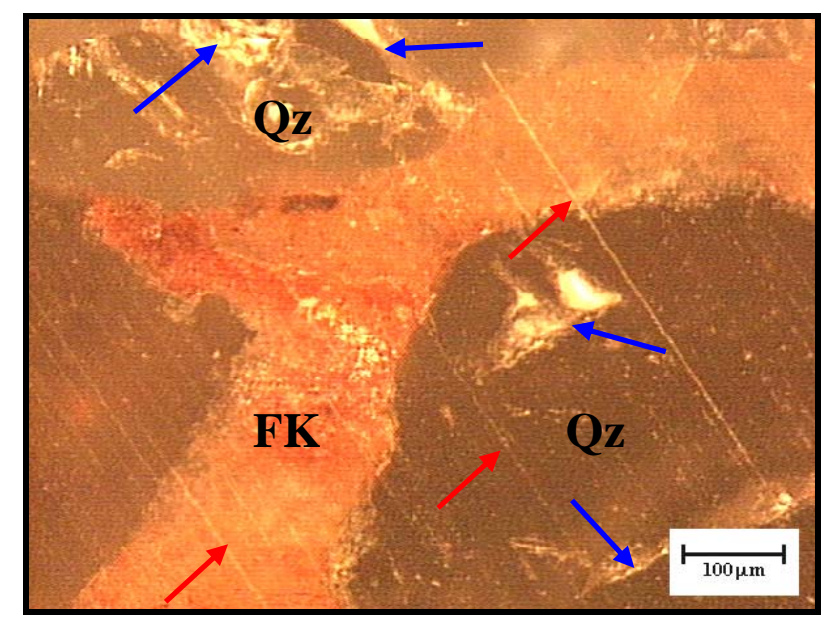

Figura 4.62 - Amostra do granito Vermelho Capão Bonito submetido a solicitações de desgaste com abrasivo 220 mesh. Notar a presença de microfissuras intragrão (seta azul) e riscos deixados pelo abrasivo (seta vermelha).

\subsubsection{SEXTA ETAPA (\#400 MESH)}

Da quinta para a sexta etapa ocorre uma sensível diminuição na granulometria do abrasivo, o que se reflete, para o "granito" Preto Indiano, numa superfície menos rugosa e com valores de rugosidade mineral situados na casa dos 100 microns e rugosidade de contatos de 1200 microns (Figura 4.63). 


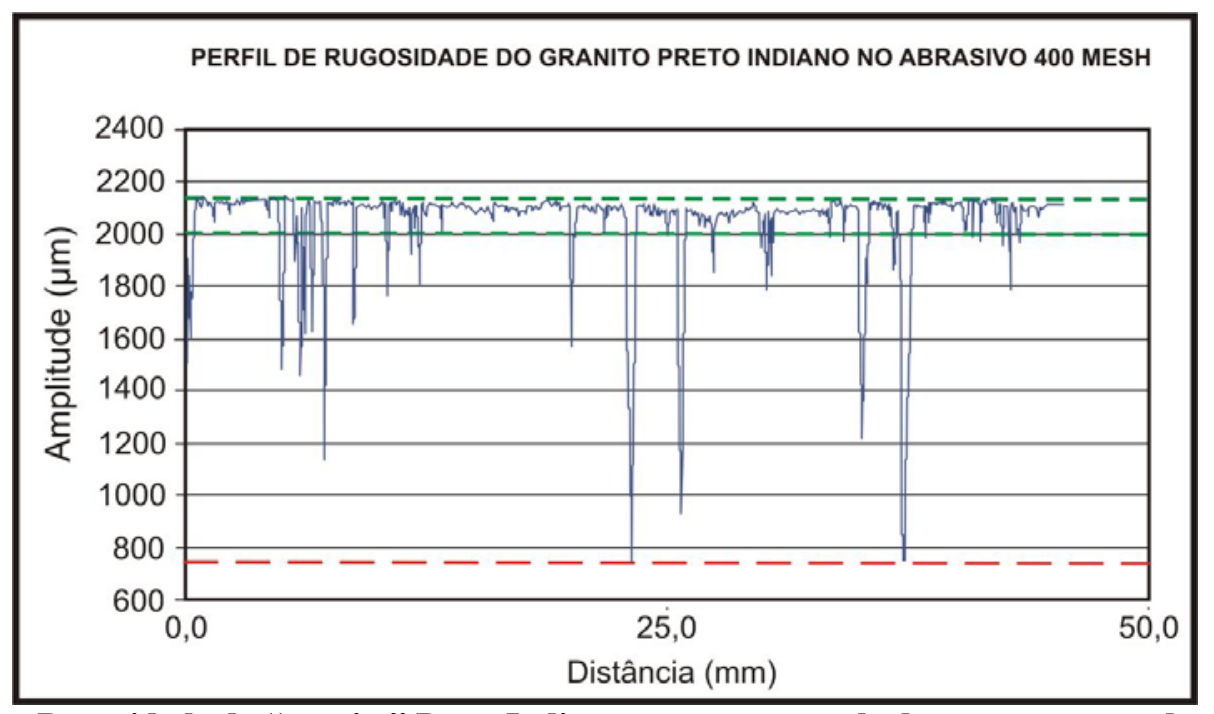

Figura 4.63 - Rugosidade do “granito” Preto Indiano na sexta etapa de desgaste, mostrando a separação dos dois tipos de irregularidades: Rugosidade mineral (tracejado verde) e Rugosidade de contatos (tracejado vermelho).

A cada etapa de desgaste, os valores da rugosidade mineral e rugosidade de contatos do "granito" Preto Indiano ficam cada vez mais distantes. Isto se deve, primeiramente, ao fator mineralógico, visto que esta rocha apresenta minerais com propriedades bem diferenciadas entre si. É possível notar a seguir (Figura 4.64) o desenvolvimento das trincas presentes nos cristais de granada (intragrão). O segundo aspecto é sua estrutura bandada, que, independente do diminuição da granulometria do abrasivo, continuará interferindo na rugosidade final (Figura 4.65).

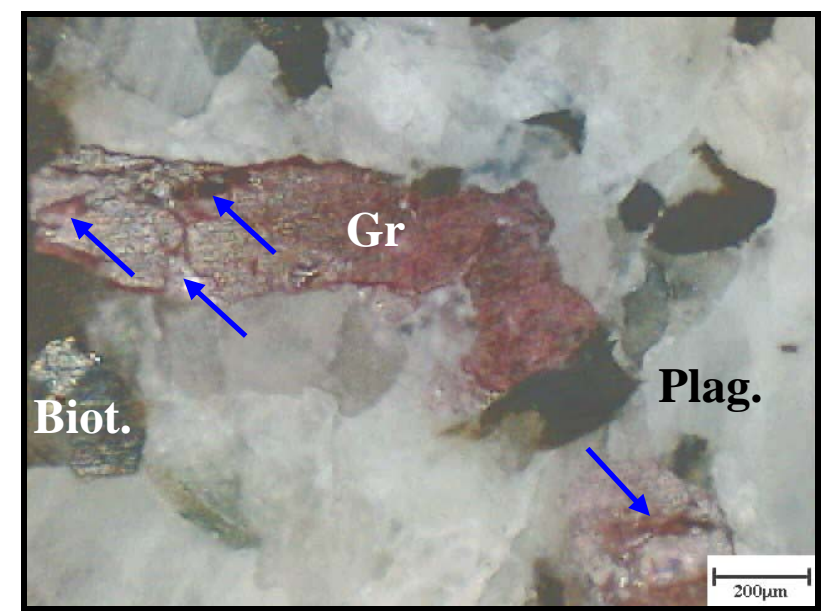

Figura 4.64 - Amostra do "granito" Preto Indiano submetido a solicitações de desgaste com abrasivo 400 mesh. Notar o desenvolvimento de microfissuras intragrão (seta azul). 


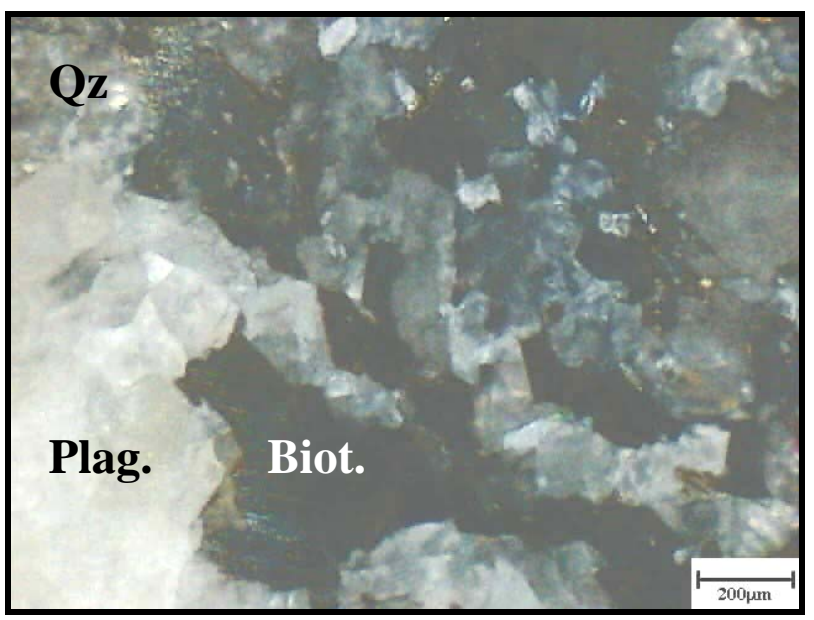

Figura 4.65 - Aspecto da intercalação composicional presente no “granito” Preto Indiano.

O granito Vermelho Brasília nesta fase apresenta um $\mathrm{R}_{\max }$ na ordem de 100 microns (Figura 4.66). Foi possível notar, nesta fase, que o fechamento desta rocha (termo utilizado pelo setor industrial para a diminuição das irregularidades nos contatos de grãos) é bom (Figura 4.67) e atribuído principalmente aos valores próximos de dureza entre os dois componentes principais, quarto e feldspato potássico. Em sienitos, onde a presença de quartzo se limita, em casos extremos a 5\%, este fechamento é ainda melhor. Tal propriedade irá interferir na durabilidade do brilho da rocha bem como a maior resistência ao ataque químico.

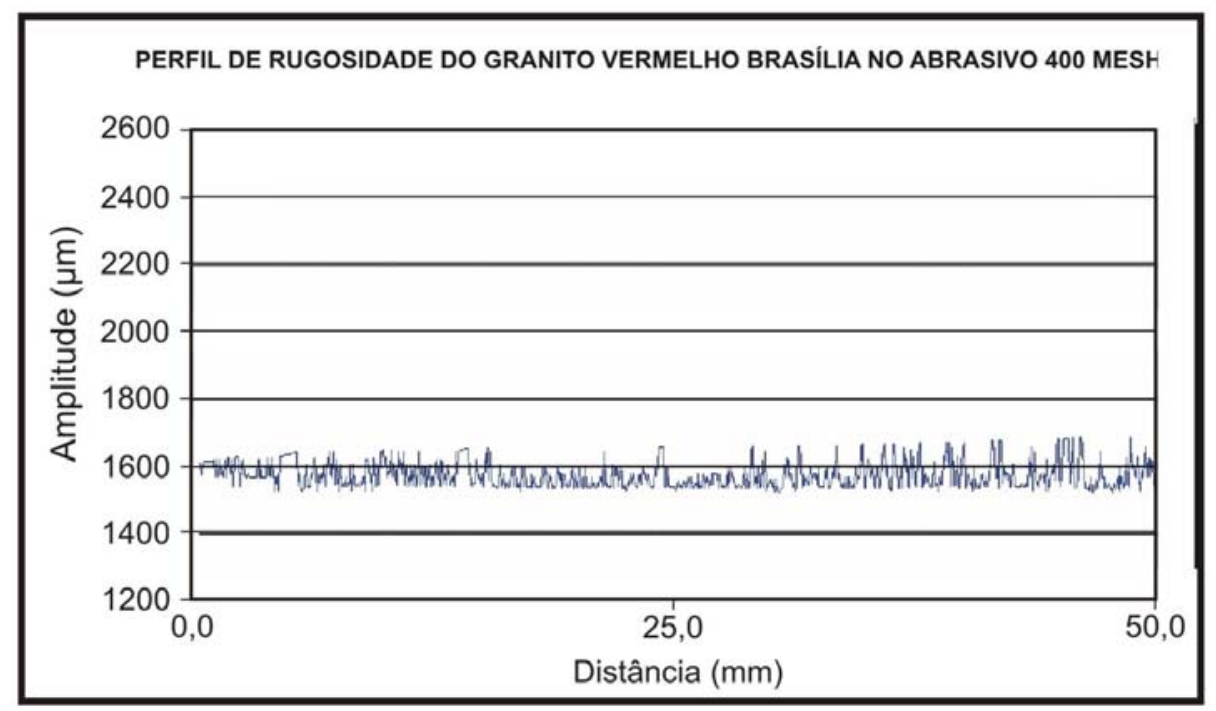

Figura 4.66 - Rugosidade do granito Vermelho Brasília na sexta etapa de desgaste. 


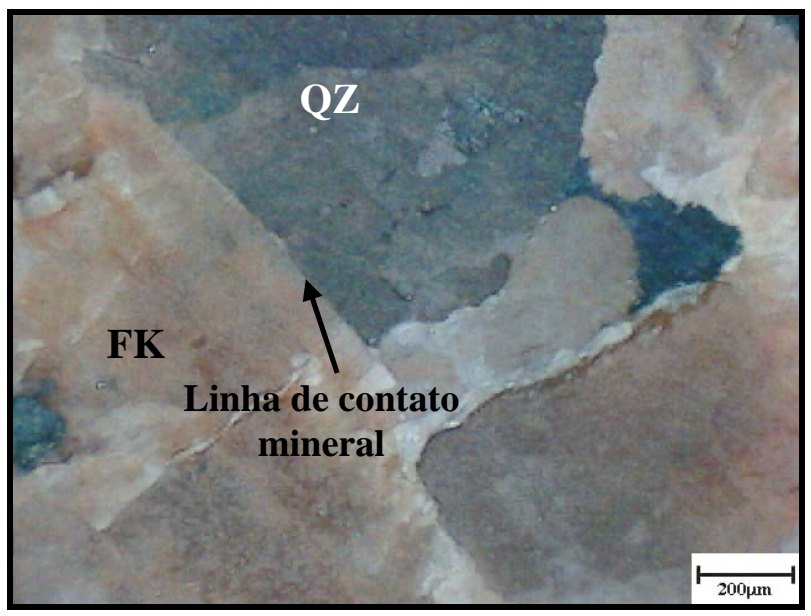

Figura 4.67 - Amostra do granito Vermelho Brasília submetido a solicitações de desgaste com abrasivo 400 mesh. Notar o bom fechamento entre os cristais de quartzo e feldspato potássico.

Na sexta etapa de desgaste o granito Cinza Castelo continuou apresentando uma uniformidade no seu perfil de rugosidade, com valores de $\mathrm{R}_{\max }$ raramente ultrapassando 50 microns (Figura 4.68). As principais descontinuidades encontradas foram microfissuras intragrão e riscos deixados pelo abrasivo (Figura 4.69).

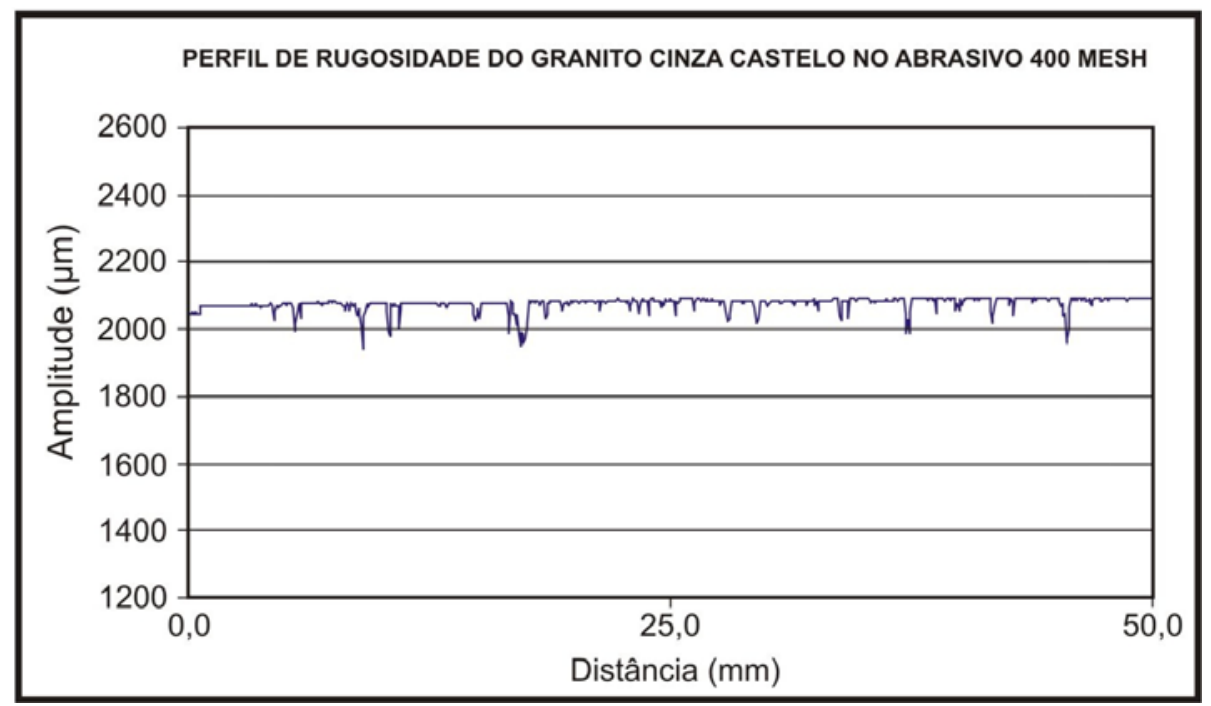

Figura 4.68 - Rugosidade do granito Cinza Castelo na sexta etapa de desgaste. 


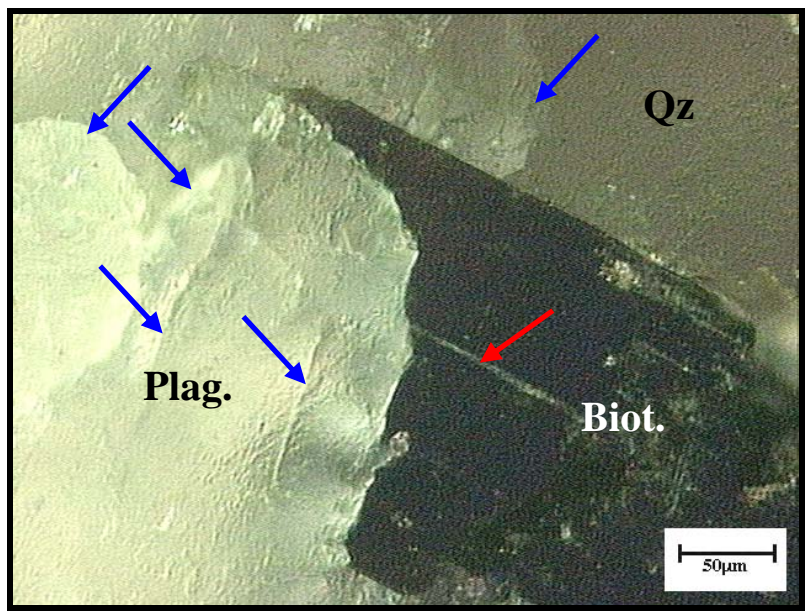

Figura 4.69 - Amostra do granito Cinza Castelo submetido a solicitações de desgaste com abrasivo 400 mesh. Notar a presença de microfissuras intragrão (seta azul) e riscos deixados pelo abrasivo (seta vermelha).

O “granito" Desert Storm mostrou nesta etapa, de modo geral, um perfil de rugosidade uniforme, diferindo apenas porções com $\mathrm{R}_{\max }$ variando de 100 a 50 microns, possivelmente devido a variação composicional da rocha (Figura 4.70). As microfissuras intragrão são as responsáveis pelas maiores amplitudes do perfil de rugosidade (Figura 4.71).

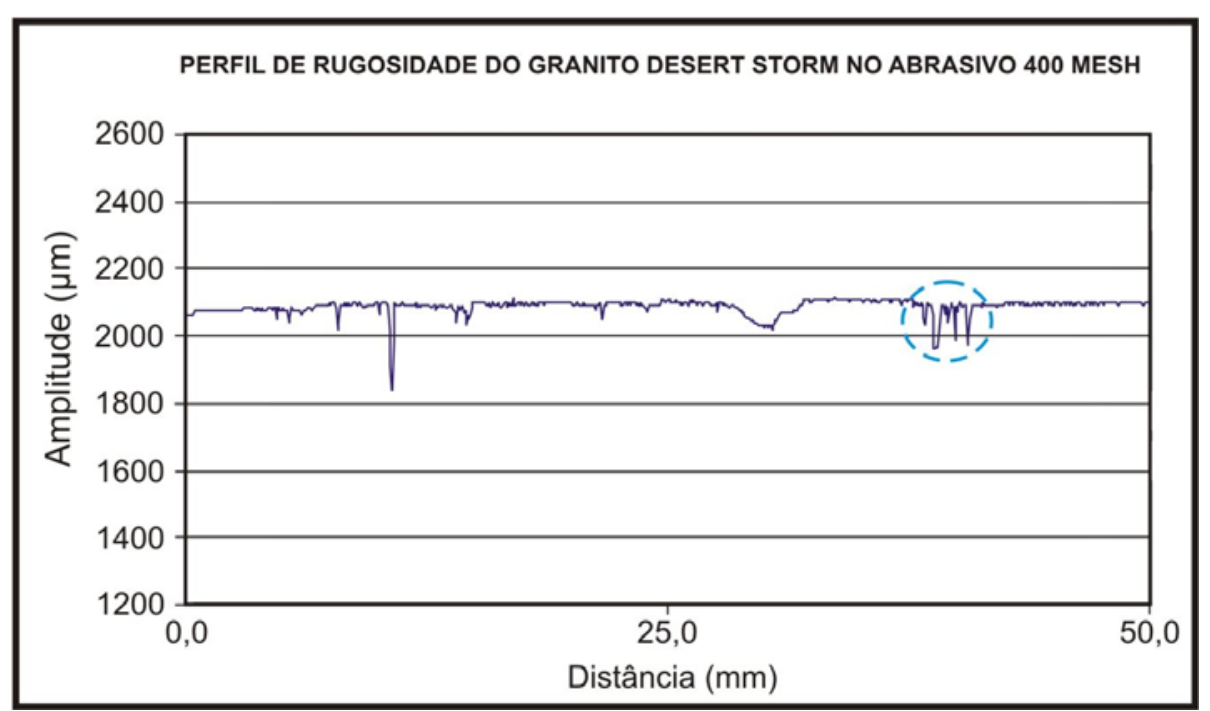

Figura 4.70 - Rugosidade do “granito” Desert Storm na sexta etapa de desgaste. Notar níveis mais rugosos devido ao bandamento composicional da rocha (tracejado). 


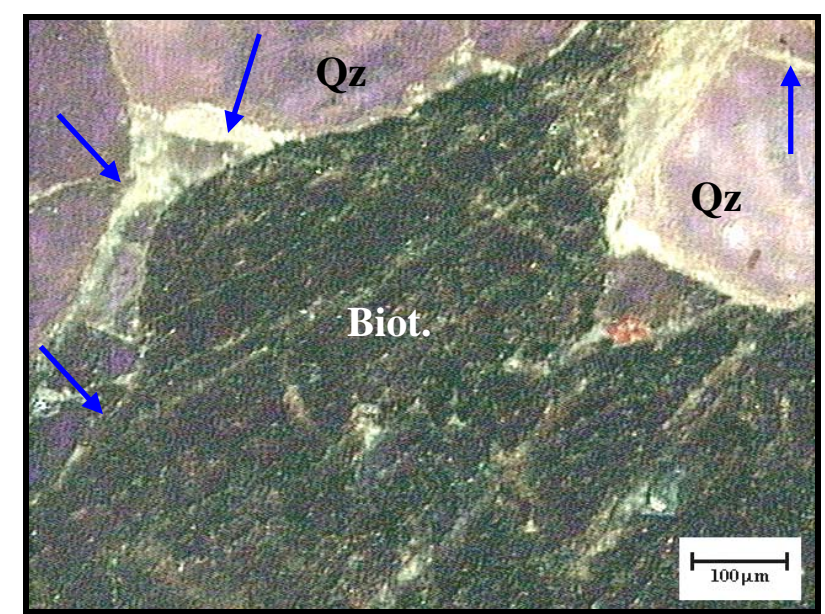

Figura 4.71 - Amostra do "granito” Desert Storm submetido a solicitações de desgaste com abrasivo 400 mesh. Notar a presença de microfissuras intragrão (seta azul).

Esta rocha, a partir desta fase, apresenta porções do perfil de rugosidade quase não mensuráveis pelo equipamento utilizado. Os valores de $\mathrm{R}_{\max }$ ficaram em torno de 50 microns (Figura 4.72). Só em um maior detalhe é possível verificar que existem microfissuras intragrão e riscos deixados pelo abrasivo na superfície da rocha (Figura 4.73).

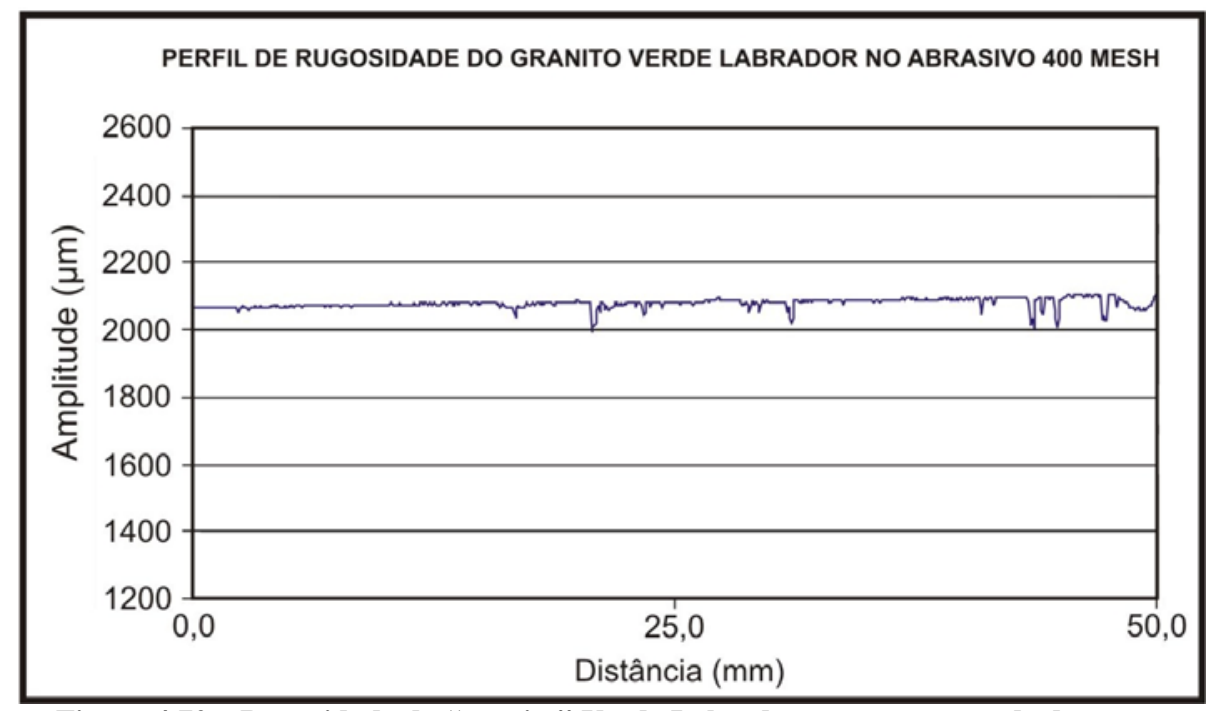

Figura 4.72 - Rugosidade do "granito” Verde Labrador na sexta etapa de desgaste. 


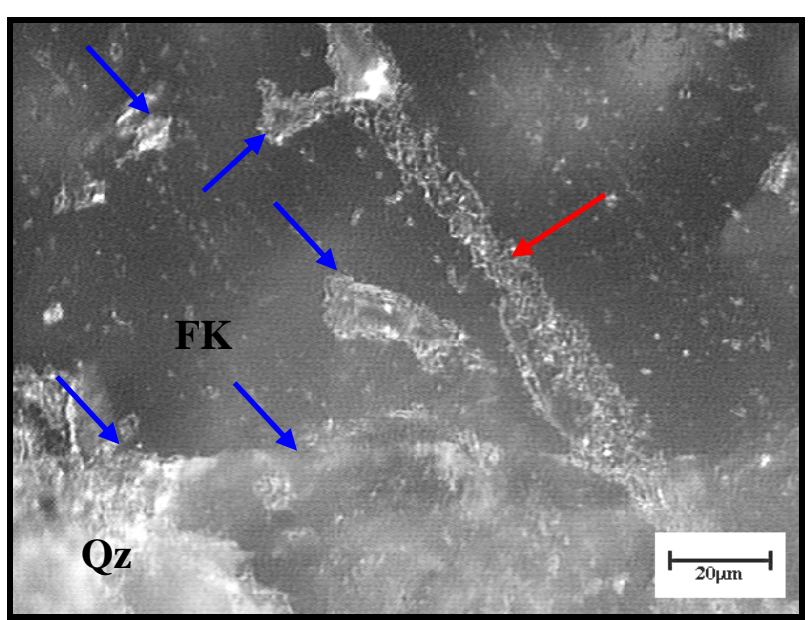

Figura 4.73 - Amostra do "granito" Verde Labrador submetido a solicitações de desgaste com abrasivo 400 mesh. Notar a presença de microfissuras intragrão (seta azul) e riscos deixados pelo abrasivo (seta vermelha).

Nesta fase, o granito Vermelho Capão Bonito apresentou um padrão diferenciado de perfil de rugosidade quando comparado às verificadas nas etapas anteriores. $O \mathrm{R}_{\max }$ ficou na casa dos 500 microns e foi possível notar uma separação em a rugosidade de contatos e rugosidade mineral, a princípio incomum pra esse tipo de rocha que tende a ser isotrópica. Isso pode ter ocorrido devido a uma possível abertura de planos de clivagem nesta etapa de desgaste, visto que tais depressões ocorrem preferencialmente em porções específicas do perfil (Figura 4.74). As microfissuras intragrão são as principais responsáveis pelas maiores depressões encontradas no perfil (Figura 4.75).

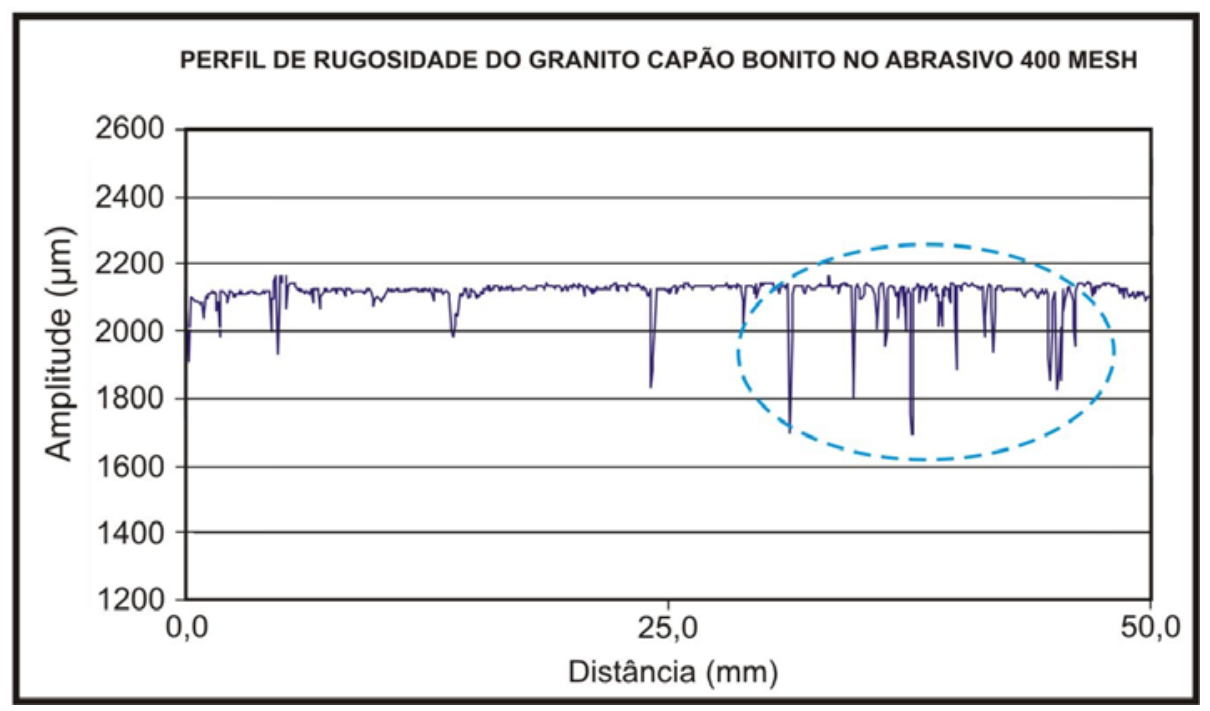

Figura 4.74 - Rugosidade do granito Vermelho Capão Bonito na sexta etapa de desgaste. 


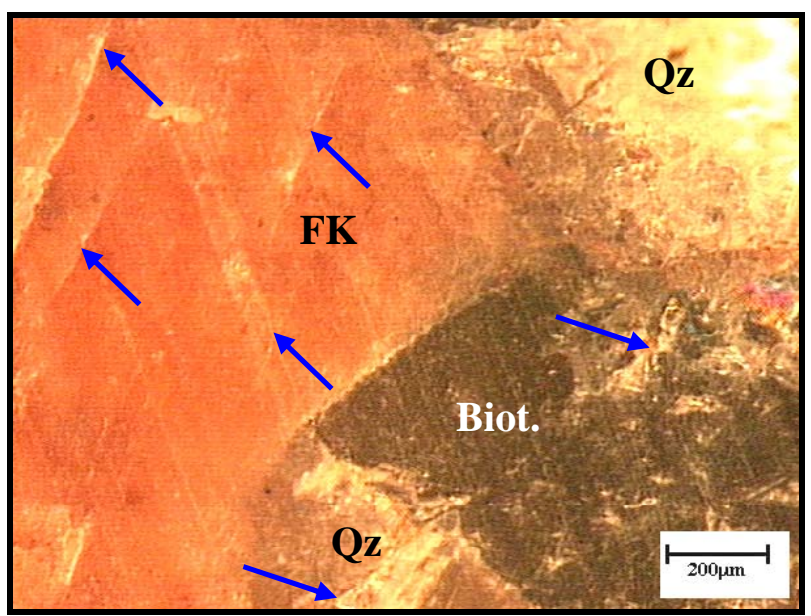

Figura 4.75 - Amostra do granito Vermelho Capão Bonito submetido a solicitações de desgaste com abrasivo 400 mesh. Notar a presença de microfissuras intragrão (seta azul) e riscos deixados pelo abrasivo (seta vermelha).

\subsubsection{SÉTIMA ETAPA (\#600 MESH)}

O gráfico de rugosidade do "granito" Preto Indiano nesta fase apresentou em seu início um erro de forma, possivelmente devido a uma pequena movimentação do corpo-deprova no instante da medição (Figura 4.76).

No entanto, ainda é possível observar neste gráfico que os valores da rugosidade mineral se encontram na casa dos 100 microns e a rugosidade de contatos em 200 microns. Tal resultado de rugosidade de contatos pode ser devido a problemas no instante da medição, o que merece ser alvo de uma nova análise posterior.

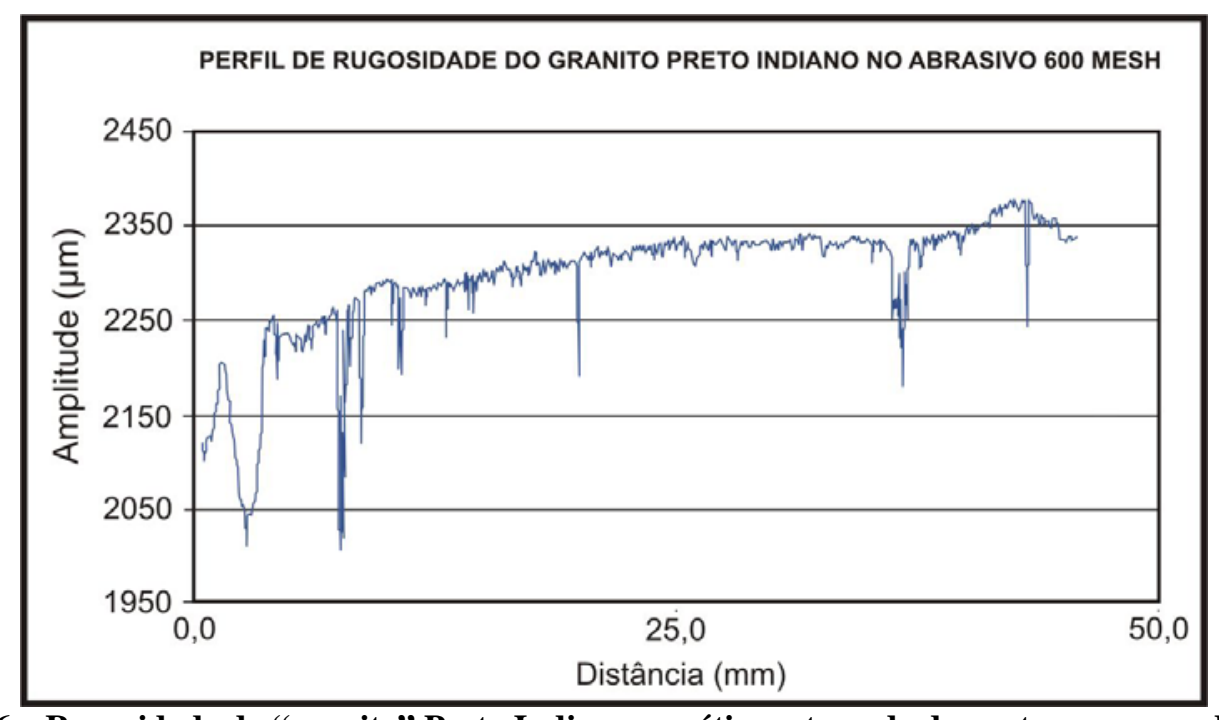

Figura 4.76 - Rugosidade do "granito" Preto Indiano na sétima etapa de desgaste, com erro de forma na parte inicial. 
Nesta fase se nota o desenvolvimento das trincas associadas aos cristais de granada de maneira mais flagrante, que permitem depreender que o desprendimento de fragmentos de cristais de granada, principal responsável pela geração de depressões neste material ocorre nas etapas finais do polimento (Figura 4.77). Tal inferência é corroborada pela imagem deste material na fase final de lustro, onde este mineral se encontra intensamente fraturado. Ocorrem também nesta rocha intensos microfissuramentos intragrão e intergrão.

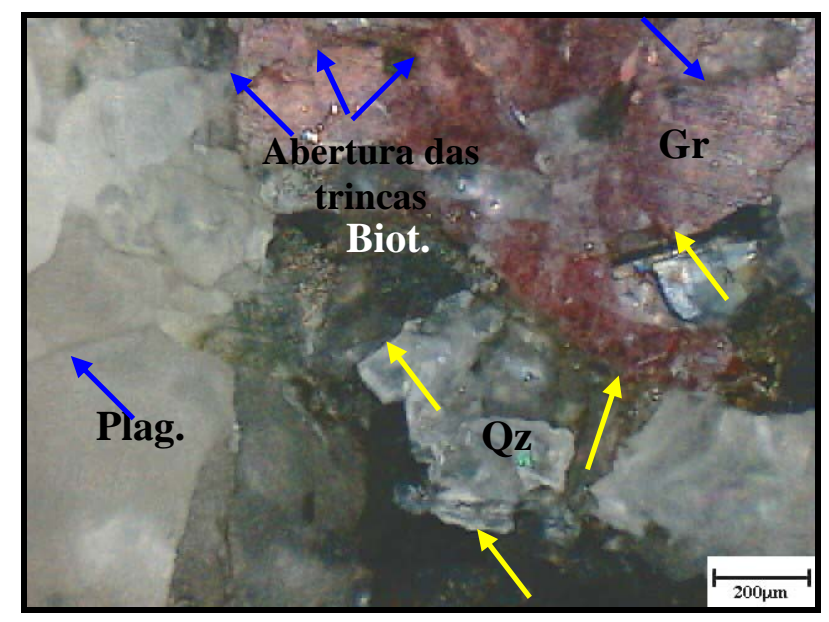

Figura 4.77 - Amostra do "granito" Preto Indiano submetido a solicitações de desgaste com abrasivo 600 mesh. Notar a presença de microfissuras intergrão (seta amarela) e intragrão (seta azul), principalmente desenvolvidas em cristais de granada.

Para o granito Vermelho Brasília, o gráfico de rugosidade mostra uma variação considerável no padrão da curva bem como erros de forma ao longo do perfil (Figura 4.78). No início da leitura, os valores de rugosidade variam muito pouco, aproximadamente poucas dezenas de microns, enquanto que ao final, os valores chegam a 100 microns. 


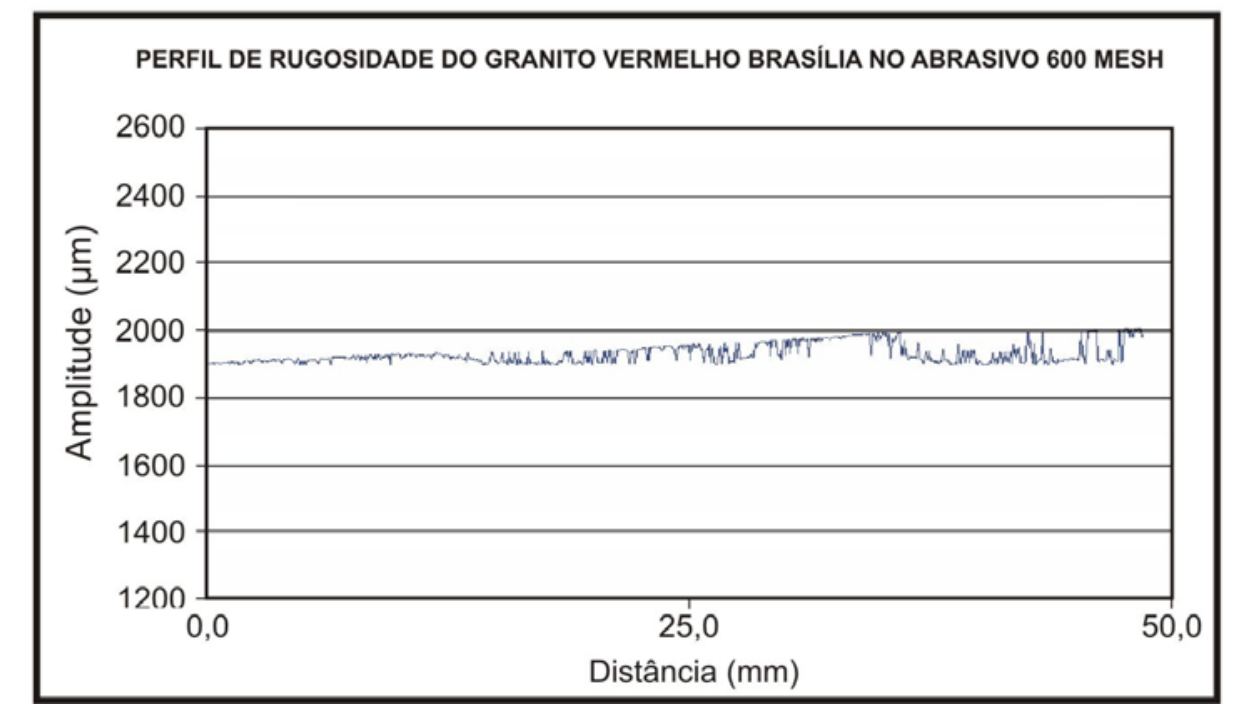

Figura 4.78 - Rugosidade do granito Vermelho Brasília na sétima etapa de desgaste.

A foto a seguir (Figura 4.79) mostra uma superfície de um cristal de feldspato potássico com rugosidade muito baixa e com planos de clivagem configurando pontos com maiores irregularidades (microfissuras intragrão). Tal feição pode explicar a diferença no padrão o perfil de rugosidade, a medida que a ponta do rugosímetro, ao passar em tais estruturas, pode gerar esta característica no perfil.

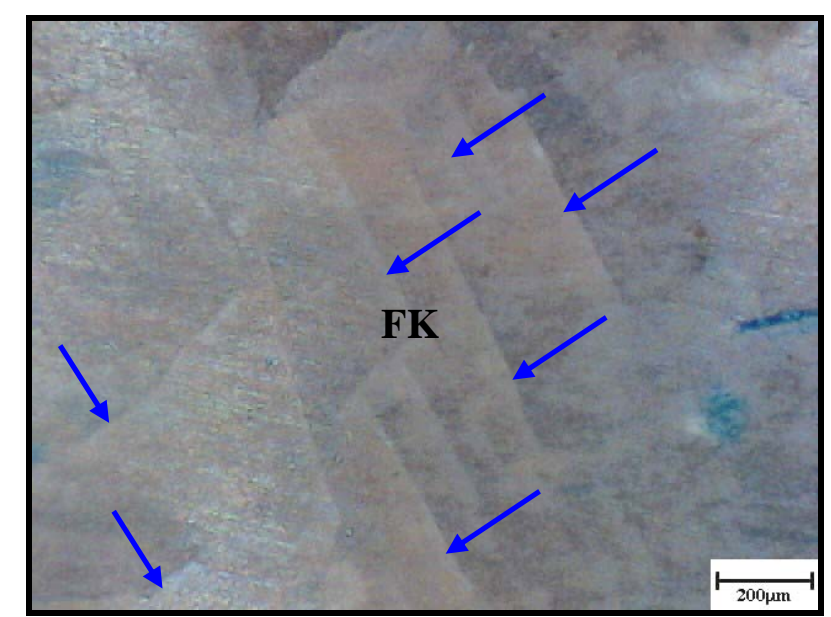

Figura 4.79 - Amostra do granito Vermelho Brasília submetido a solicitações de desgaste com abrasivo 600 mesh. Notar a presença de microfissuras intragrão (seta azul) no cristal de feldspato potássico.

Em relação à etapa anterior, o granito Cinza Castelo apresentou uma porção maior do perfil de rugosidade com linha plana, indicando a rugosidade mínima registrada pelo rugosímetro utilizado na pesquisa. Poucos pontos do perfil apresentaram $R_{\max }$ de 
aproximadamente 100 microns (Figura 4.80). As principais descontinuidades registradas foram devido a ocorrência de microfissuras intragrão e intergrão (Figura 4.81).

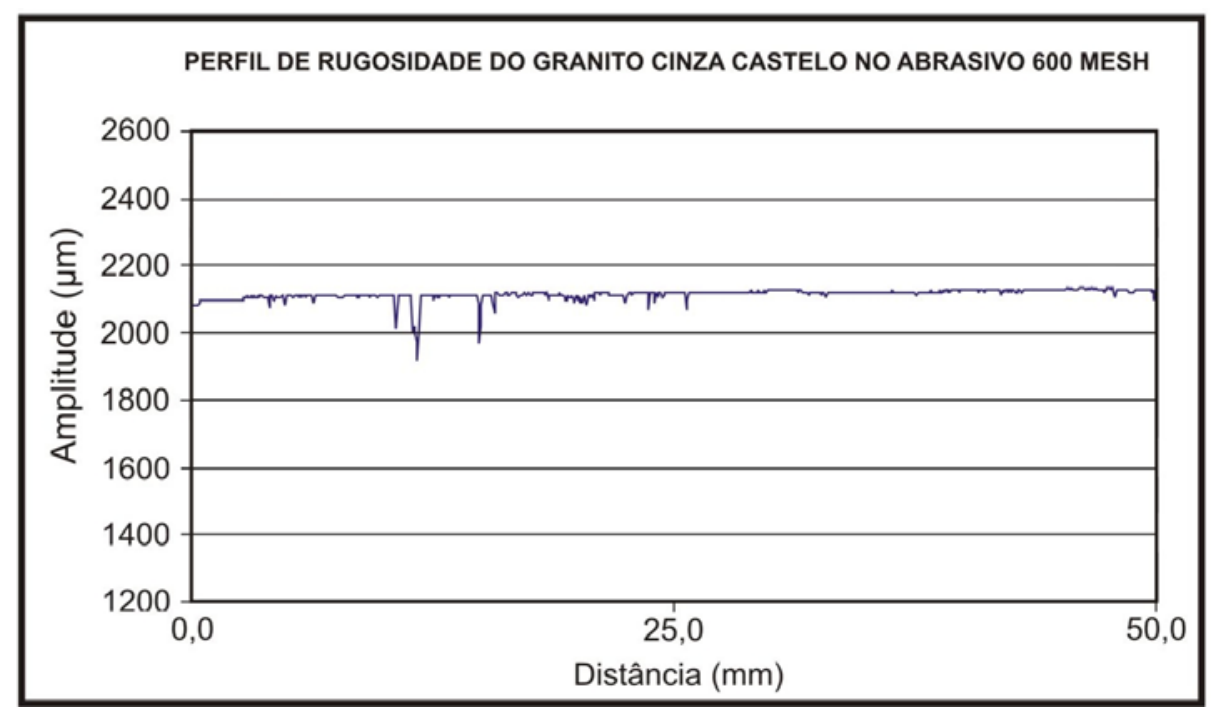

Figura 4.80 - Rugosidade do granito Cinza Castelo na sétima etapa de desgaste.

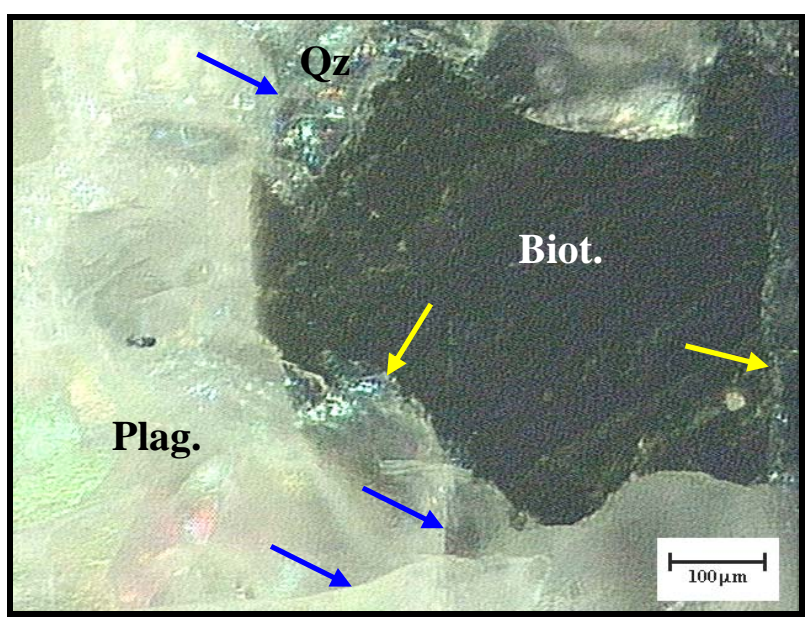

Figura 4.81 - Amostra do granito Cinza Castelo submetido a solicitações de desgaste com abrasivo 600 mesh. Notar a presença de microfissuras intragrão (seta azul) e intergrão (seta amarela).

O "granito" Desert Storm apresentou um aumento da porção plana do perfil de rugosidade exibindo um pico com $\mathrm{R}_{\max }$ de 200 microns, sendo, porém, verificado em apenas um ponto do perfil (Figura 4.82). Em linhas gerais, as maiores depressões do perfil são devidas ao contato de cristais de biotita com quarto ou feldspatos e microfissuras intergrão (Figura 4.83). 


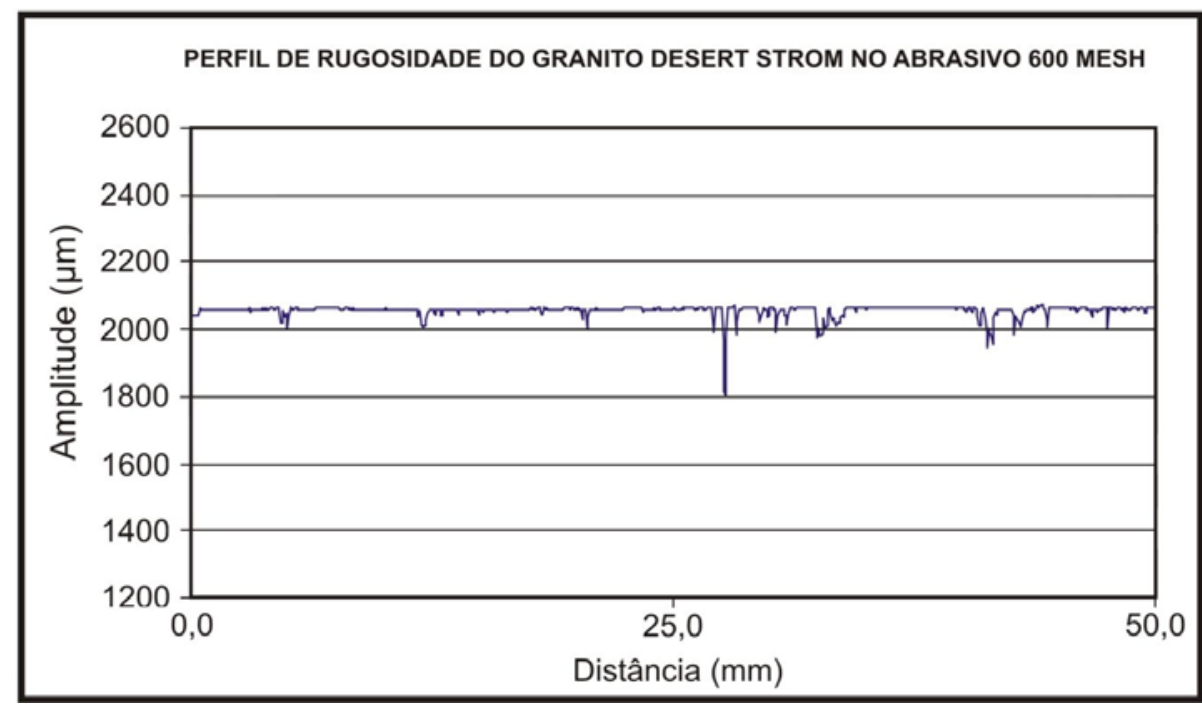

Figura 4.82 - Rugosidade do “granito” Desert Storm na sétima etapa de desgaste.

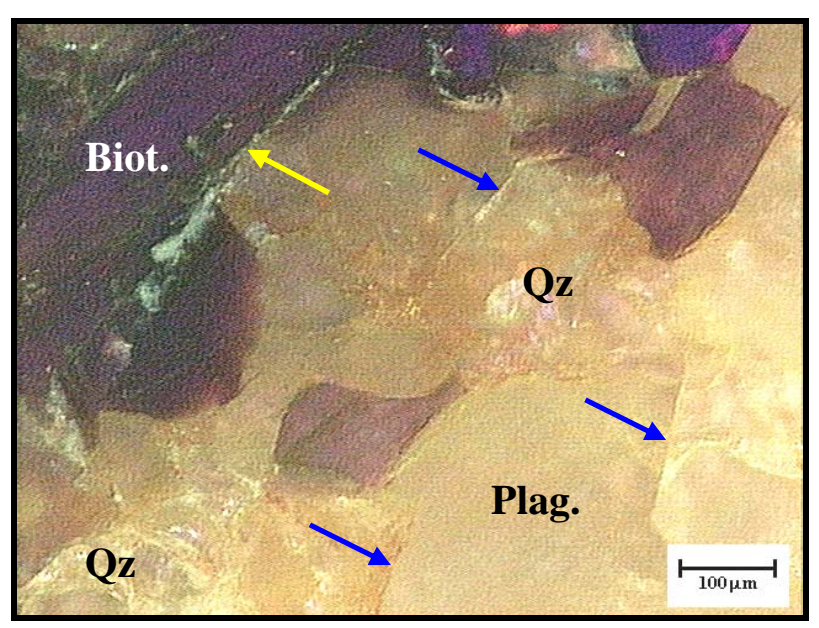

Figura 4.83 - Amostra do "granito" Desert Storm submetido a solicitações de desgaste com abrasivo 600 mesh. Notar a presença de microfissuras intragrão (seta azul) e intergrão (seta amarela).

O "granito" Verde Labrador apresentou, nessa fase, a mesma regularidade aos seus perfis de rugosidade anteriores, isto é, boa porção do perfil se encontra plana, indicando o limite de medição do equipamento. Um ponto ao longo do perfil, que representa a maior depressão, apresentou $R_{\max }$ de 300 microns (Figura 4.84). As principais descontinuidades são originadas por poucas microfissuras intragrão (Figura 4.85). 


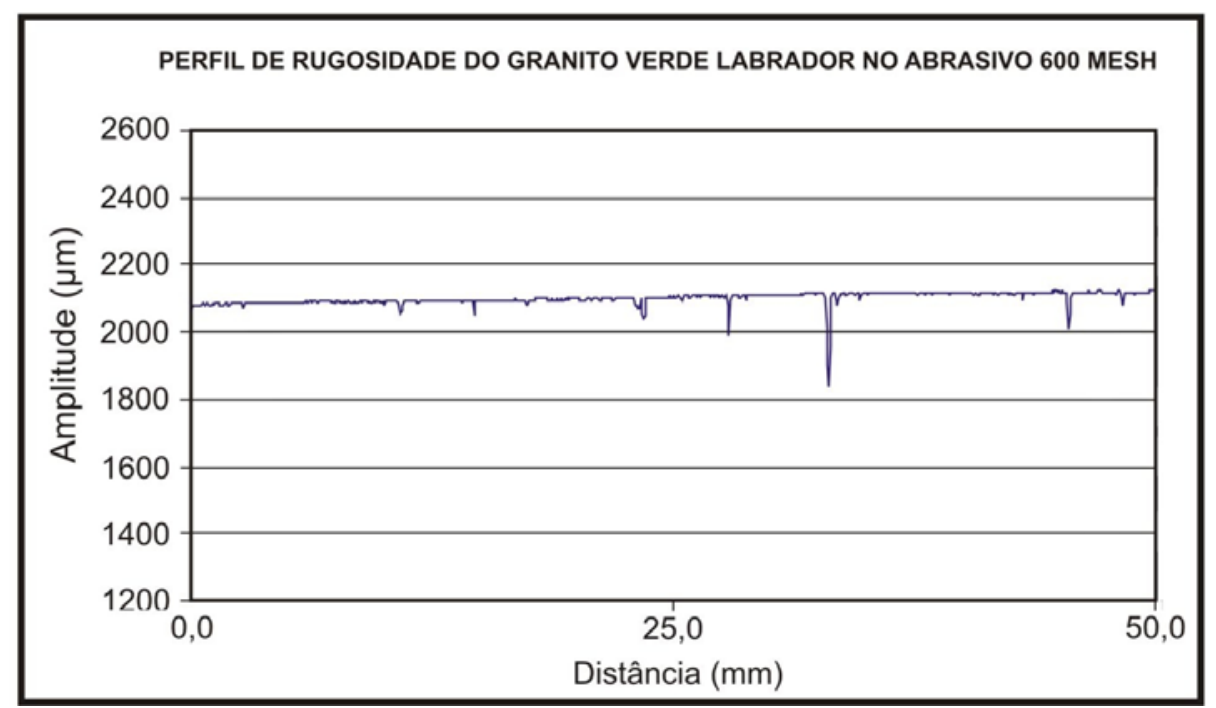

Figura 4.84 - Rugosidade do “granito” Verde Labrador na sétima etapa de desgaste.

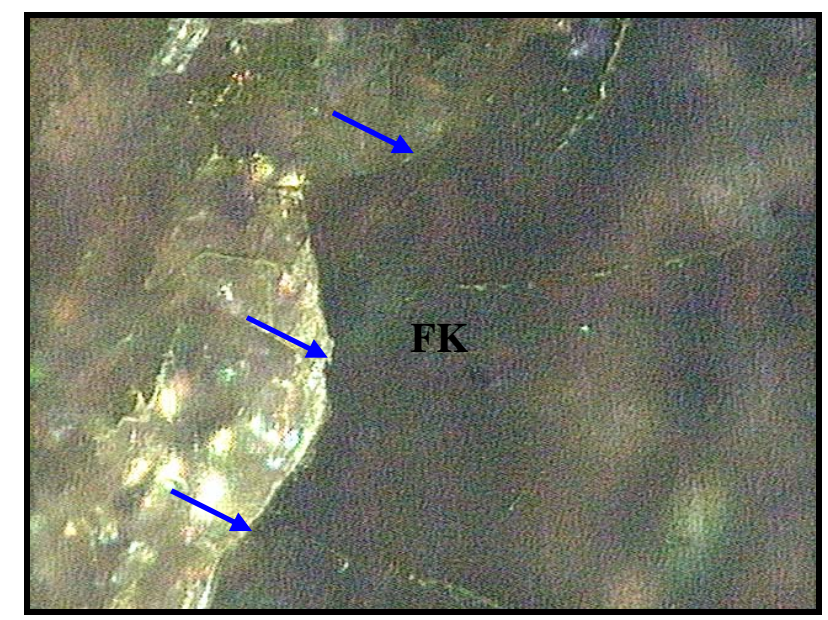

Figura 4.85 - Amostra do "granito” Verde Labrador submetido a solicitações de desgaste com abrasivo 600 mesh. Notar a presença de microfissuras intragrão (seta azul).

Nesta fase, o granito Vermelho Capão Bonito apresentou em seu perfil de rugosidade um $\mathrm{R}_{\max }$ de aproximadamente 400 microns, e a rugosidade mineral diminuiu em relação à etapa anterior, caracterizada por uma suavização da curva (Figura 4.86). Microfissuras intergrãos e intragrãos ocorrem nesta rocha e são responsáveis pelas maiores irregularidades encontradas (Figura 4.87). 


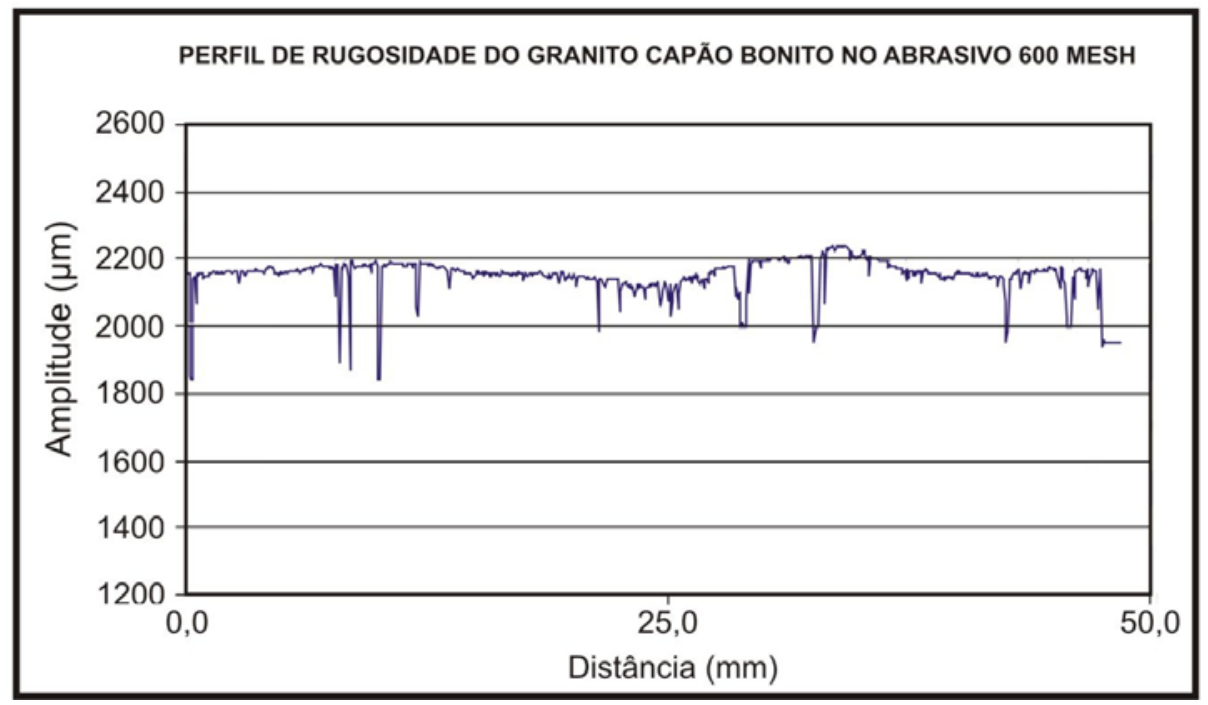

Figura 4.86 - Rugosidade do granito Vermelho Capão Bonito na sétima etapa de desgaste.

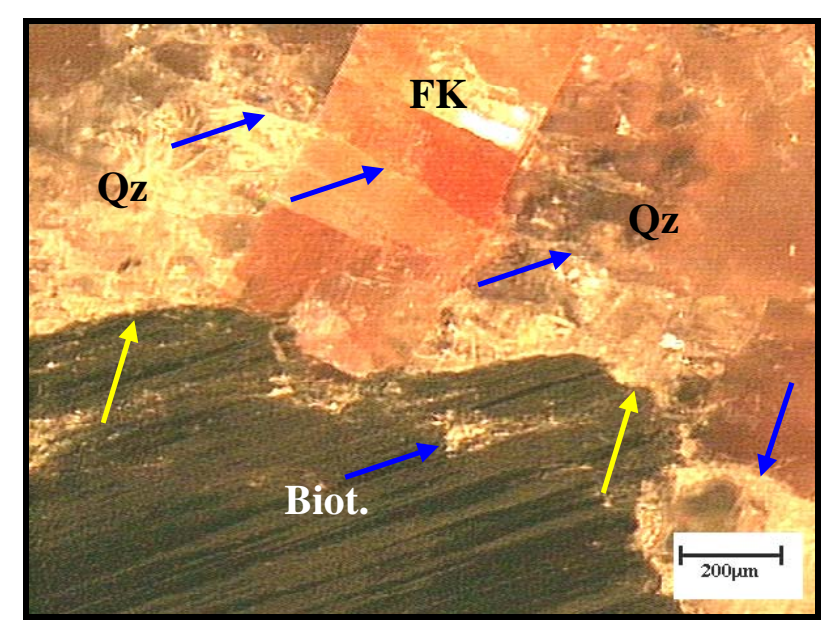

Figura 4.87 - Amostra do granito Vermelho Capão Bonito submetido a solicitações de desgaste com abrasivo 600 mesh. Notar a presença de microfissuras intragrão (seta azul) e intergrão (seta amarela).

\subsubsection{OITAVA ETAPA (\#800 MESH)}

$\mathrm{Na}$ antepenúltima etapa de polimento o "granito" Preto Indiano se caracteriza por apresentar valores de rugosidade mineral na ordem de algumas dezenas de microns, enquanto que a rugosidade de contatos fica em torno de 800 microns (Figura 4.88). 


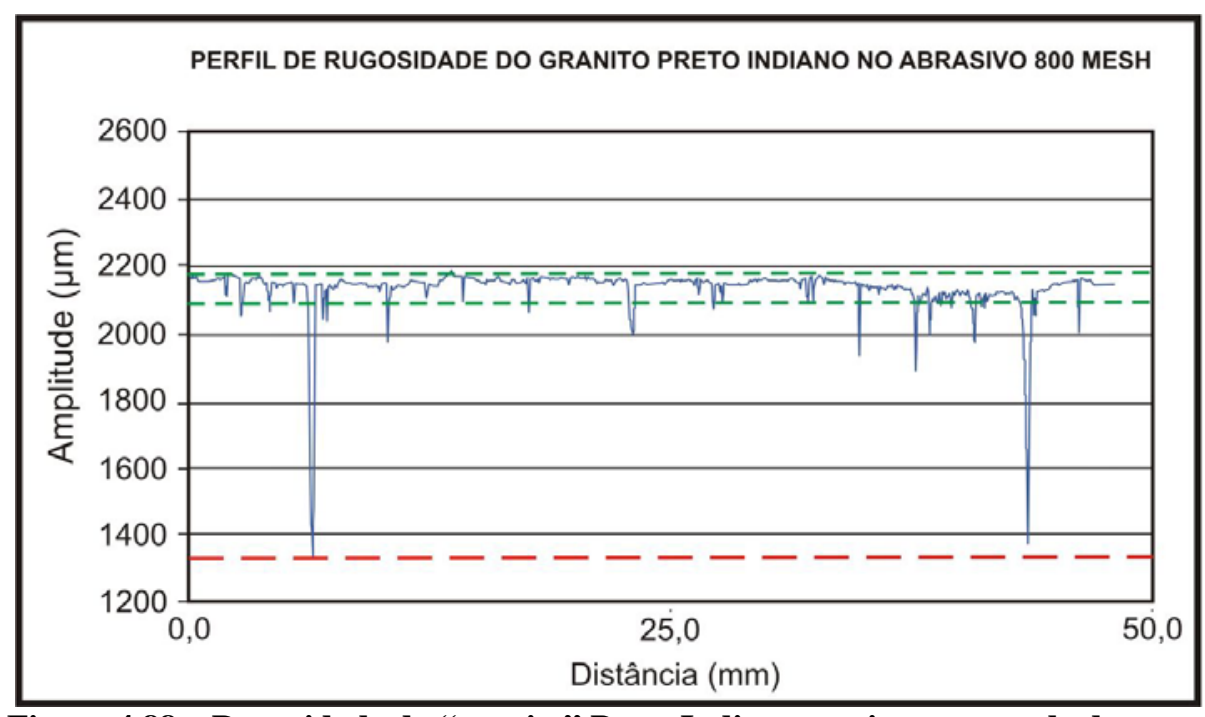

Figura 4.88 - Rugosidade do “granito” Preto Indiano na oitava etapa de desgaste.

A foto a seguir mostra que o "granito" Preto Indiano se encontra com sua superfície bem lisa e ausente de imperfeições na zona de contato entre os minerais granulares e os micáceos, ocorrendo apenas microfissuras intragrão (Figura 4.89).

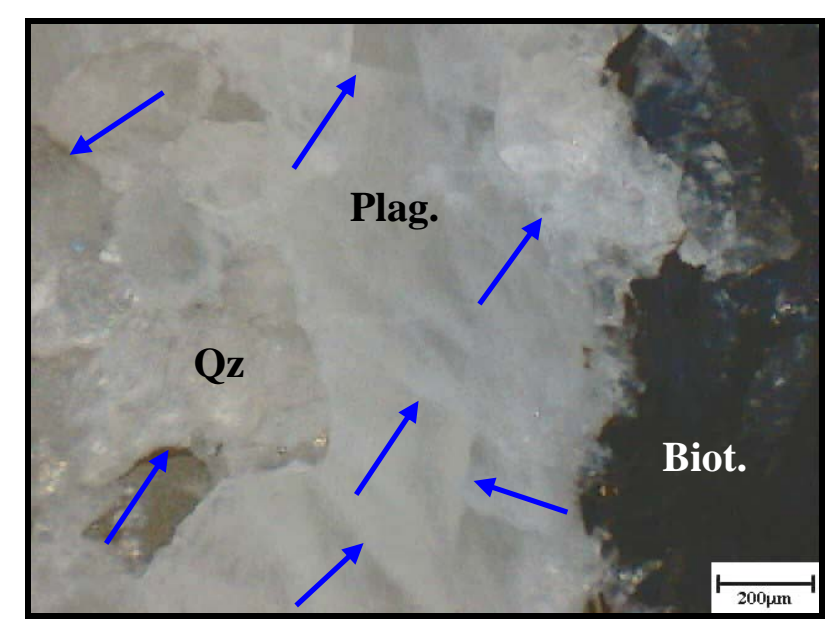

Figura 4.89 - Superfície com baixa rugosidade verificada na oitava etapa de desgaste no "granito" Preto Indiano. Notar presença de microfissuras intragrão (seta azul).

Para a amostra do granito Vermelho Brasília os valores da rugosidade mineral mostraram intervalo de rugosidade de aproximadamente 100 microns (Figura 4.90). 


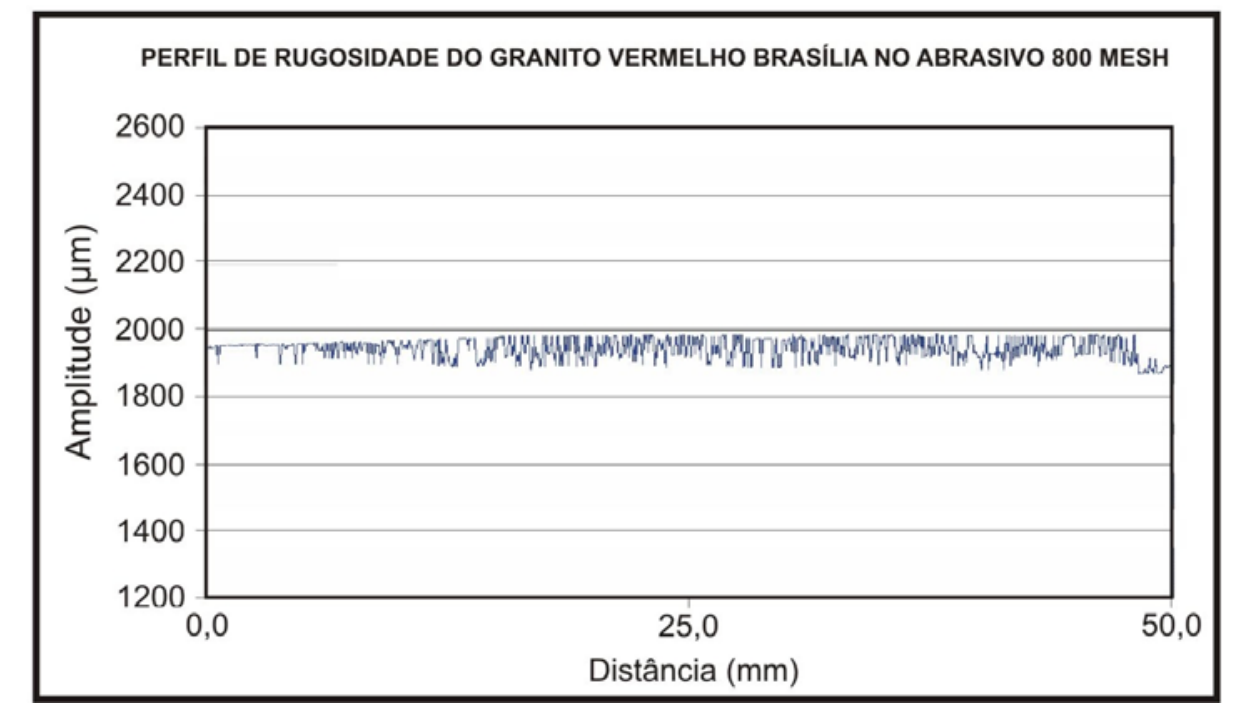

Figura 4.90 - Rugosidade do granito Vermelho Brasília na oitava etapa de desgaste.

Embora a superfície do corpo-de-prova se encontre, nesta etapa, com uma superfície pouco rugosa, os valores de rugosidade mineral, na casa dos 100 microns, são devidos ao fato da ocorrência, em alguns pontos, de pequenos trincamentos verificadas geralmente nos limites de contatos entre fases minerais diferentes (microfissura intergrão). Isto pode ser devido a uma pressão de cabeçote um pouco elevada. Algumas microfissuras intergrão são também encontradas nesta amostra (Figura 4.91).

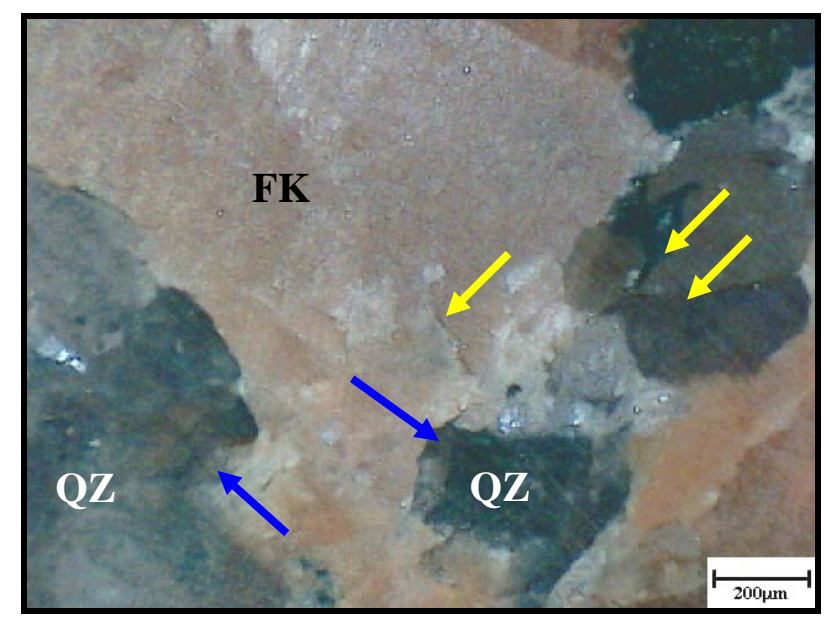

Figura 4.91 - Amostra do granito Vermelho Brasília submetido a solicitações de desgaste com abrasivo 800 mesh. Notar presença de microfissuras intragrão (seta azul) e intergrão (seta amarela).

O granito Cinza Castelo manteve o mesmo padrão da etapa anterior, ocorrendo apenas a diminuição dos pontos de maiores irregularidades. $\mathrm{O} \mathrm{R}_{\max }$ manteve-se na ordem de 100 
microns (Figura 4.92). É possível encontrar nesta fase algumas microfissuras intragrão e intergrão (Figura 4.93).

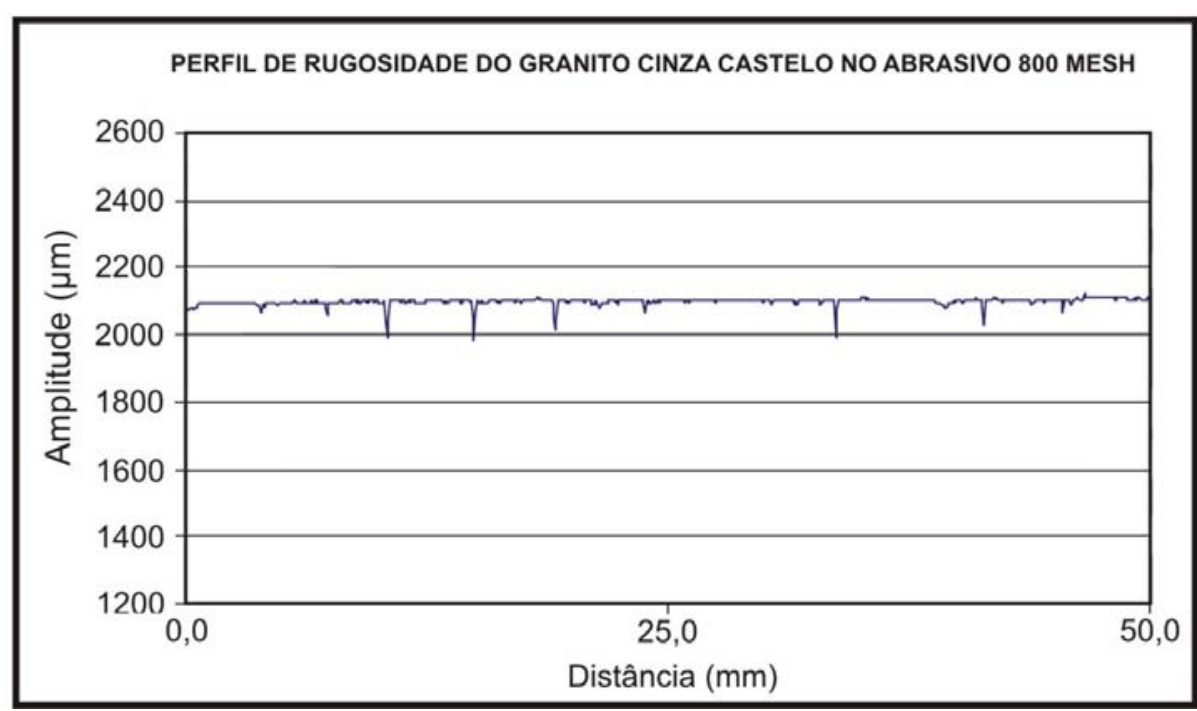

Figura 4.92 - Rugosidade do granito Cinza Castelo na oitava etapa de desgaste.

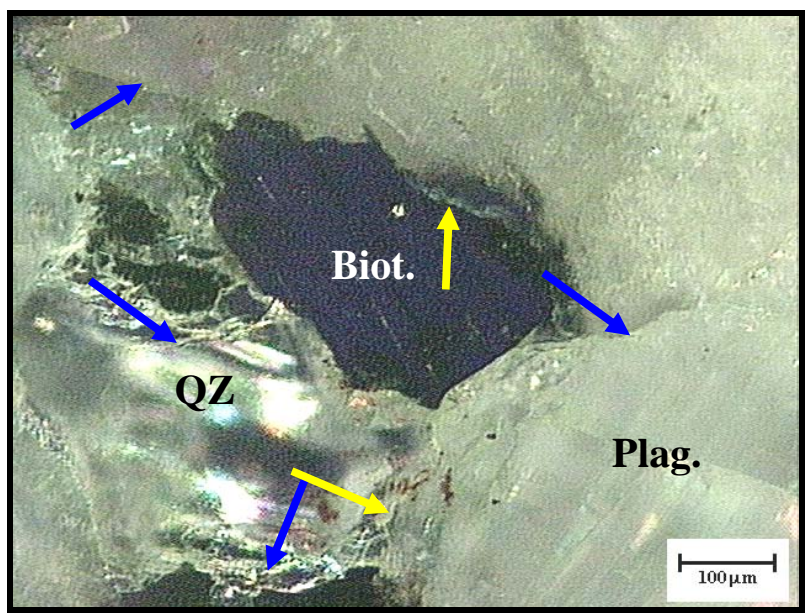

Figura 4.93 - Amostra do granito Cinza Castelo submetido a solicitações de desgaste com abrasivo 800 mesh. Notar presença de microfissuras intragrão (seta azul) e intergrão (seta amarela).

O "granito" Desert Storm apresentou uma diminuição na quantidade de irregularidades ao longo de seu perfil de rugosidade, ficando o $\mathrm{R}_{\max }$ na casa dos 100 microns (Figura 4.94). As principais irregularidades são referentes à ocorrência de poucas microfissuras intragrão (Figura 4.95). 


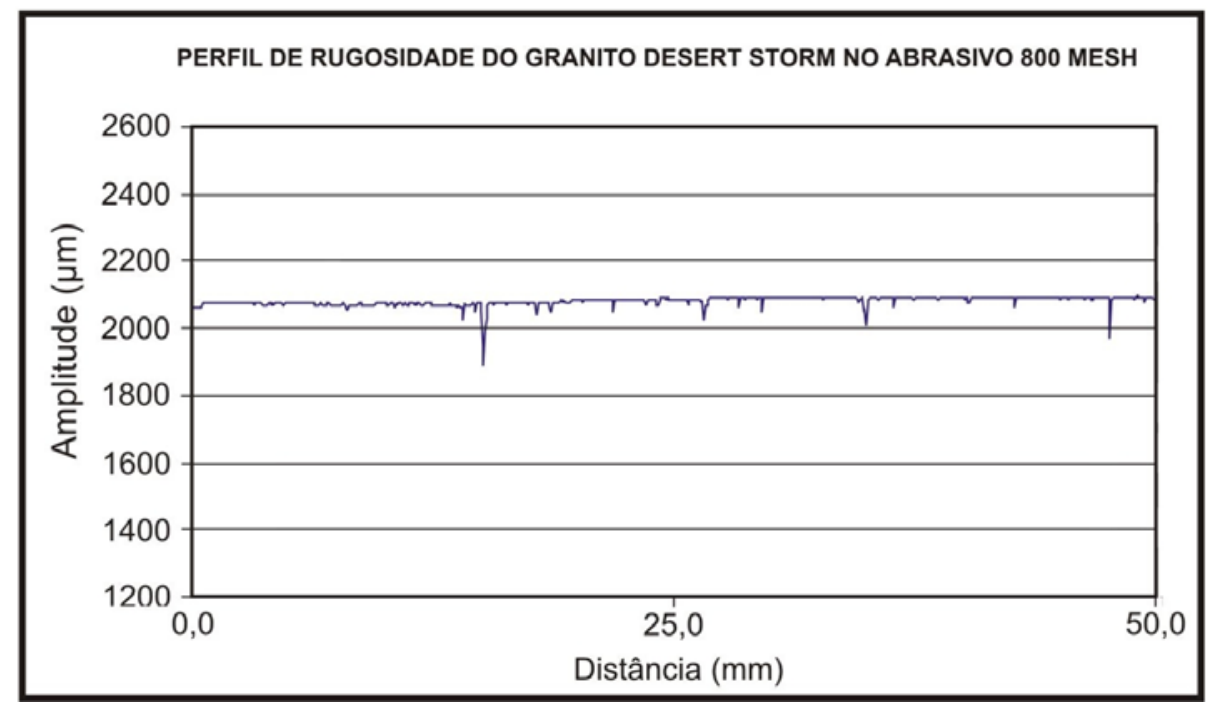

Figura 4.94 - Rugosidade do “granito” Desert Storm na oitava etapa de desgaste.

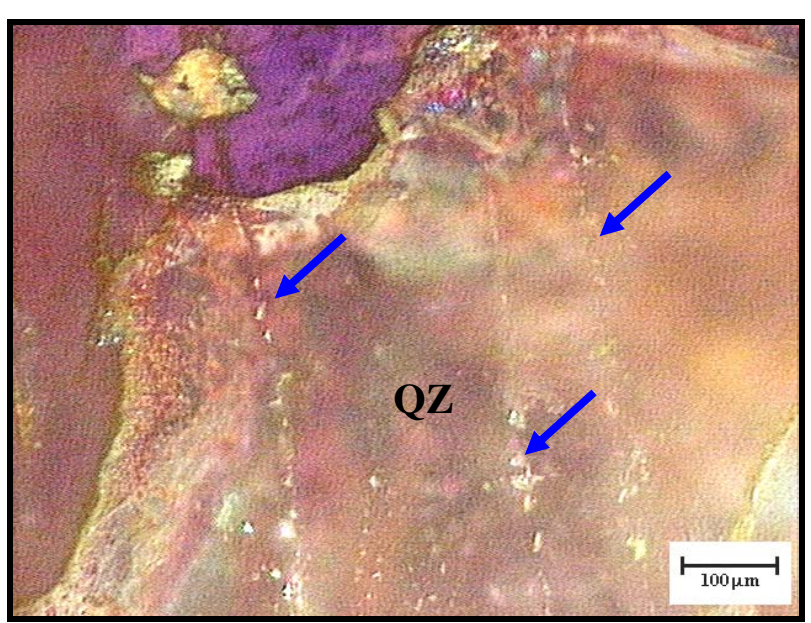

Figura 4.95 - Amostra do "granito" Desert Storm submetido a solicitações de desgaste com abrasivo 800 mesh. Notar presença de microfissuras intragrão (seta azul).

O perfil de rugosidade do "granito" Verde Labrador nesta etapa apresentou uma menor quantidade de irregularidades detectadas pelo rugosímetro, ficando as poucas depressões com o $\mathrm{R}_{\max }$ de 50 microns (Figura 4.96). As principais irregularidades encontradas são atribuídas a microfissuras intragrão (Figura 4.97). 


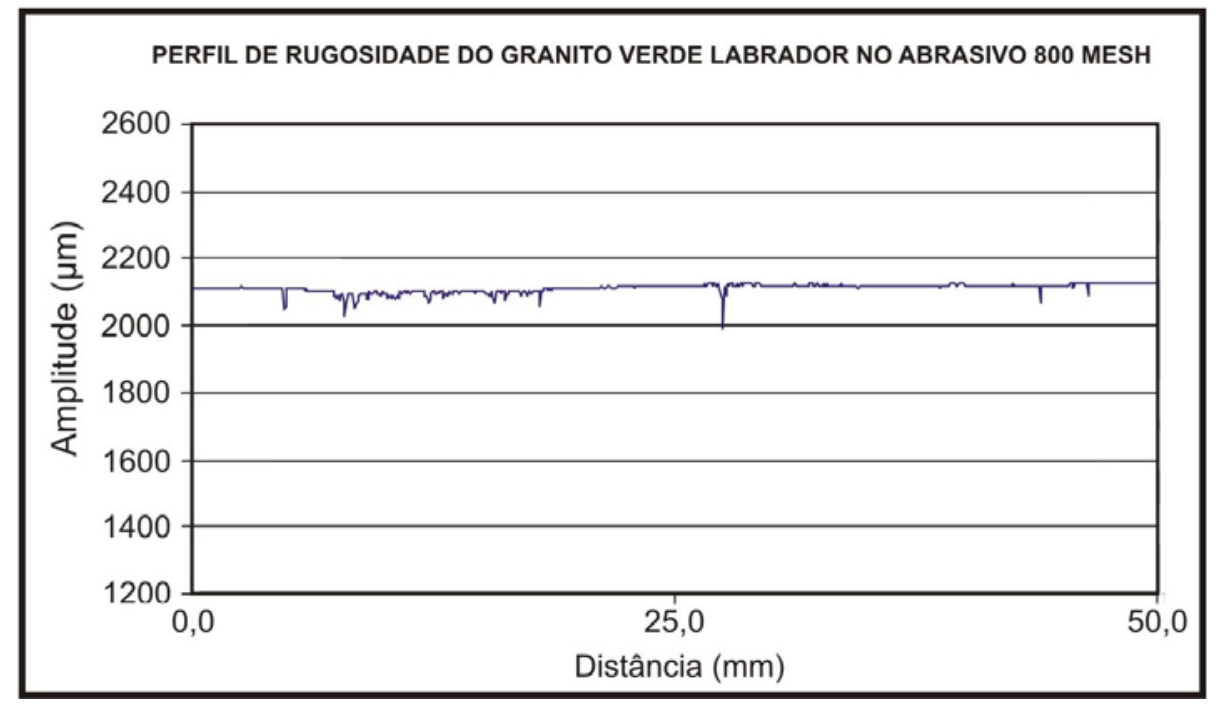

Figura 4.96 - Rugosidade do “granito” Verde Labrador na oitava etapa de desgaste.

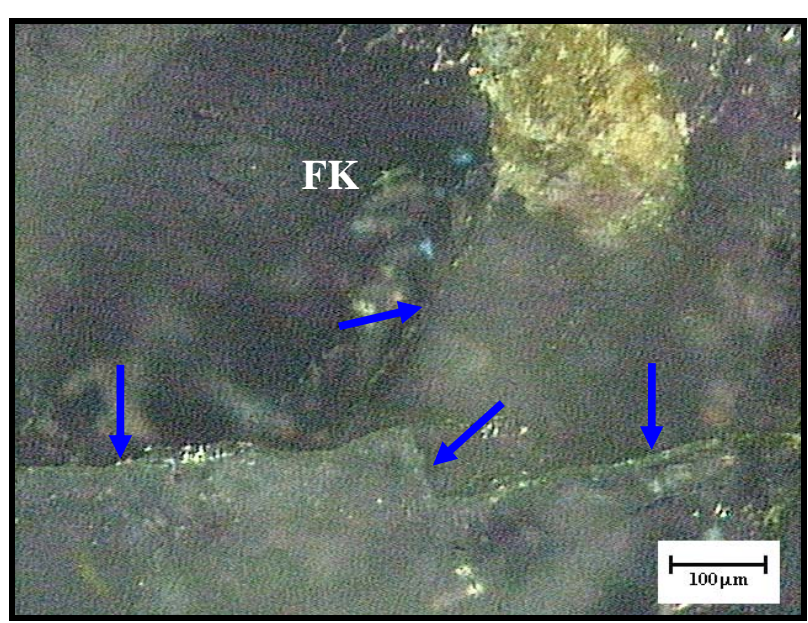

Figura 4.97 - Amostra do “granito” Verde Labrador submetido a solicitações de desgaste com abrasivo 800 mesh. Notar presença de microfissuras intragrão (seta azul).

O granito Capão Bonito mostrou uma sensível diminuição de sua rugosidade tanto no que tange à de contato intergrão quanto à rugosidade mineral. $\mathrm{O} \mathrm{R}_{\max }$ encontrado foi de 100 microns (Figura 4.98). Alguns contatos intergrão e intergrão foram os responsáveis pelas maiores descontinuidades (Figura 4.99). 


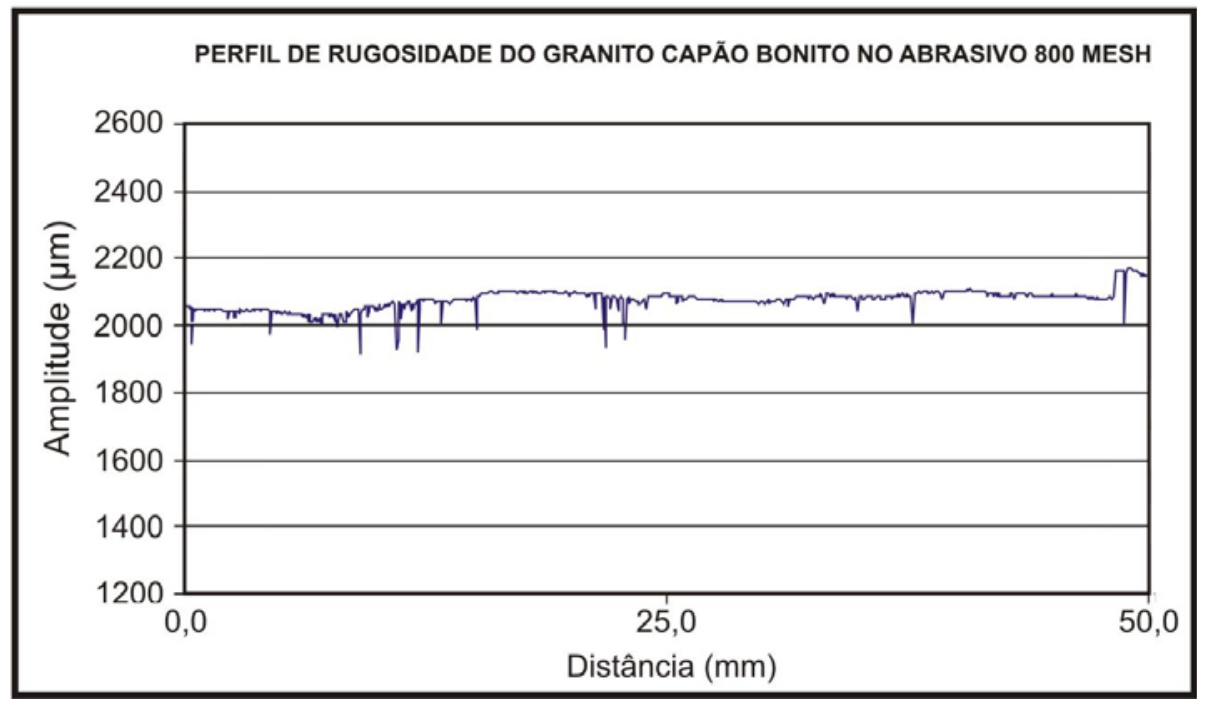

Figura 4.98 - Rugosidade do granito Vermelho Capão Bonito na oitava etapa de desgaste.

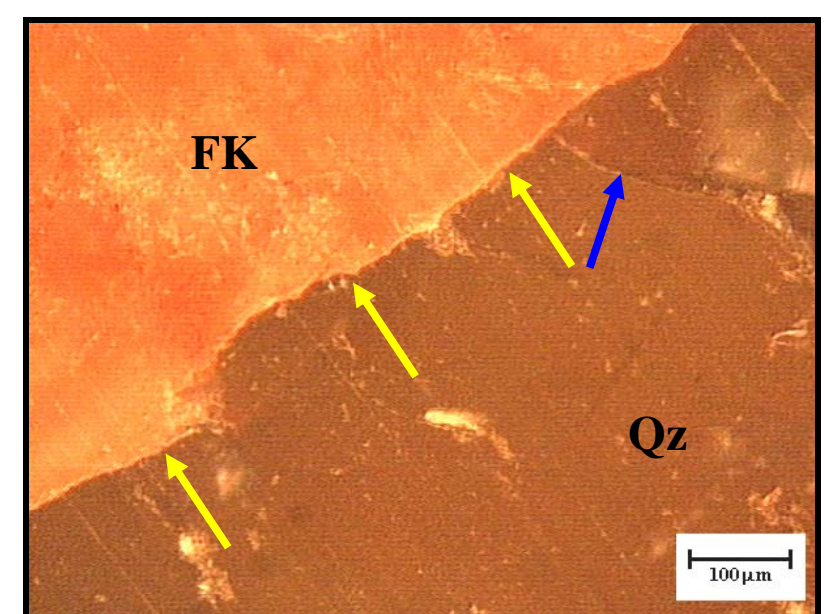

Figura 4.99 - Amostra do granito Vermelho Capão Bonito submetido a solicitações de desgaste com abrasivo 800 mesh. Notar presença de microfissuras intragrão (seta azul) e intergrão (seta amarela).

\subsubsection{NONA ETAPA (\#1200 MESH)}

O perfil de rugosidade do "granito" Preto Indiano apresenta uma rugosidade mineral na ordem de 10 microns enquanto que a rugosidade de contatos, com exceção de um ponto, se encontra na casa dos 400 microns.

É possível notar no perfil de rugosidade a seguir (Figura 4.100) que existem pequenas depressões situadas no intervalo da rugosidade mineral. Tais feições exprimem possivelmente um contato ente indivíduos de mesma fase mineral ou uma melhor separação entre os 
minerais quartzo e feldspato, em que a diferença de dureza (6 para o feldspato e 7 para o quartzo) entre estes minerais, se mostra visível. As depressões maiores (rugosidade de contatos) evidenciam o contínuo contraste de resistência ao risco entre os níveis micáceos e granulares (Figura 4.101).

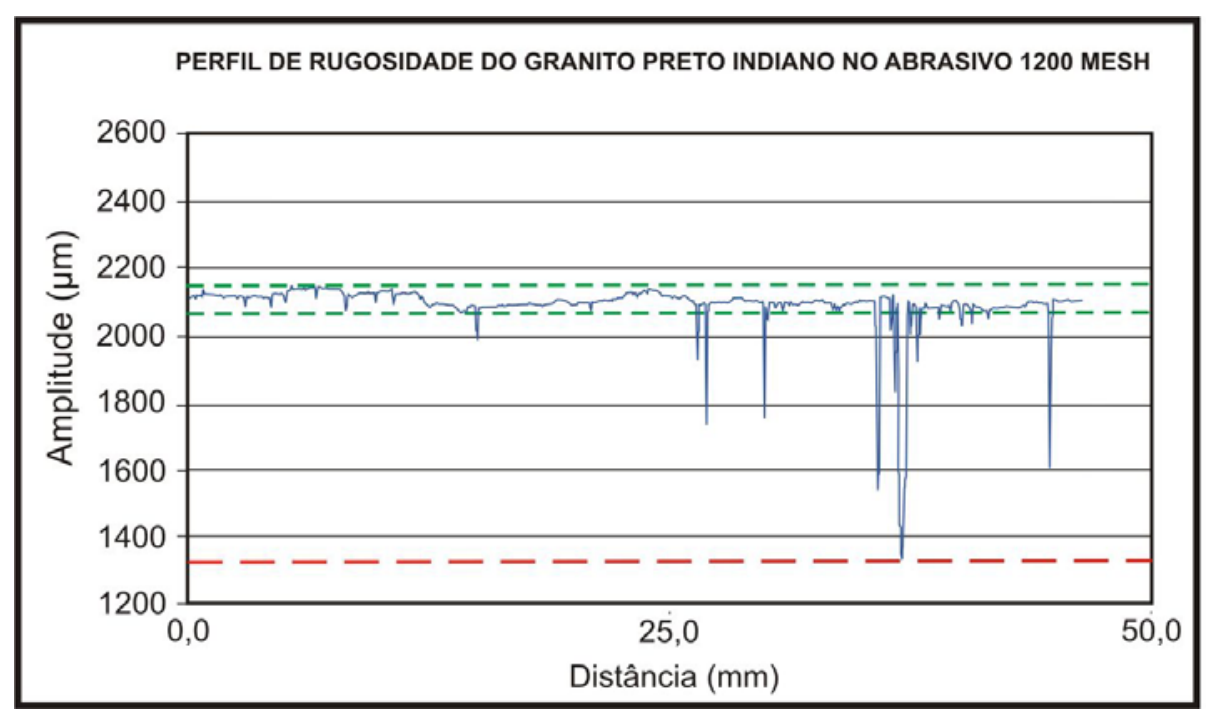

Figura 4.100 - Rugosidade do "granito” Preto Indiano na nona etapa de desgaste.

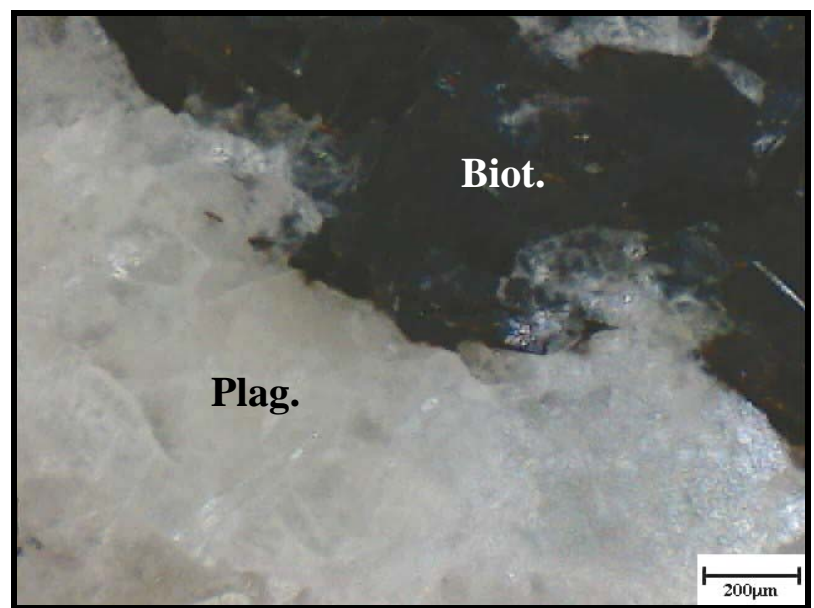

Figura 4.101 - Superfície com baixa rugosidade verificada na nona etapa de desgaste. Notar contato suave entre as fases minerais granular e micácea.

O perfil de rugosidade do granito Vermelho Brasília nesta fase repete a tendência de apresentar uma sensível diferença no seu padrão, principalmente devido à presença ou ausência de planos de clivagem. Na fase 1200 mesh fica mais clara a tendência do rugosímetro registrar, quando passa sobre um cristal de quartzo, pequenos erros de forma 
devido ao seu faturamento conchoidal; e quando passa sobre um cristal de feldspato a tendência de mostrar, de forma rítmica os sucessivos planos de clivagem (Figura 4.102).

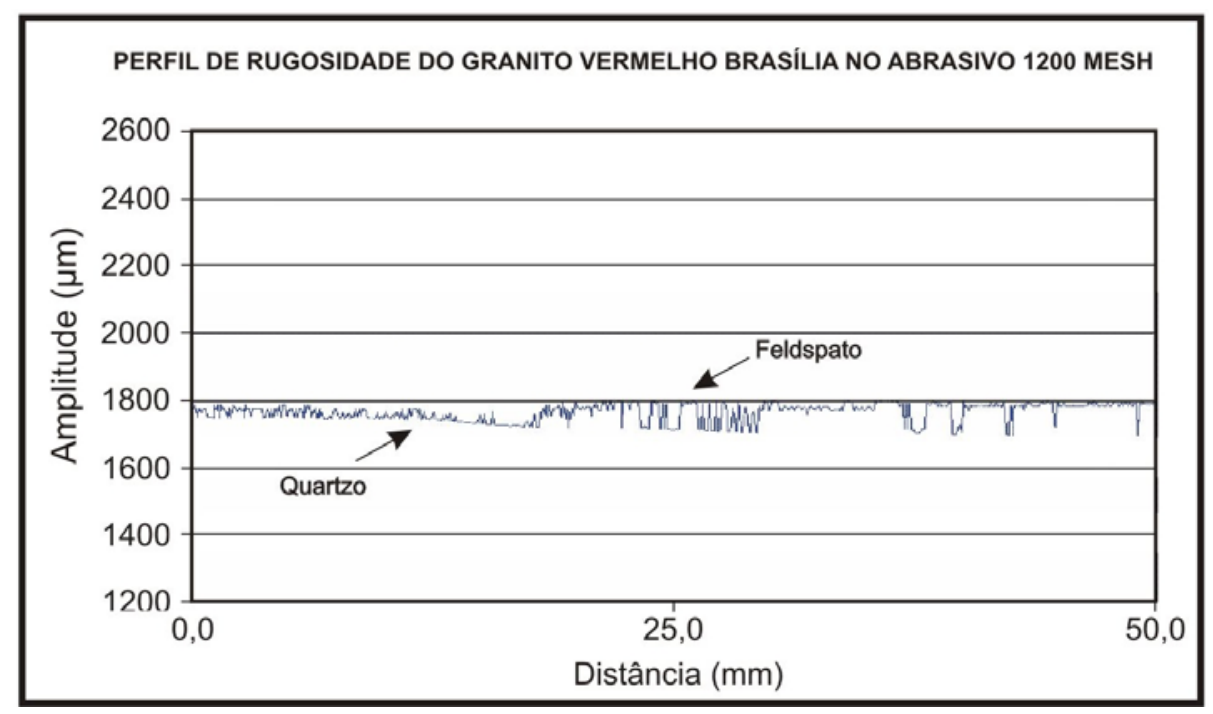

Figura 4.102 - Rugosidade do granito Vermelho Brasília na nona etapa de desgaste. Notar a diferença de padrão do traçado em função da mineralogia.

Nesta fase, quase não é possível notar os riscos feitos pelo abrasivo. As irregularidades mais proeminentes são os planos de clivagem dos feldspatos e as fraturas dos quartzos, configurando microfissuras intragrão (Figuras 4.103).

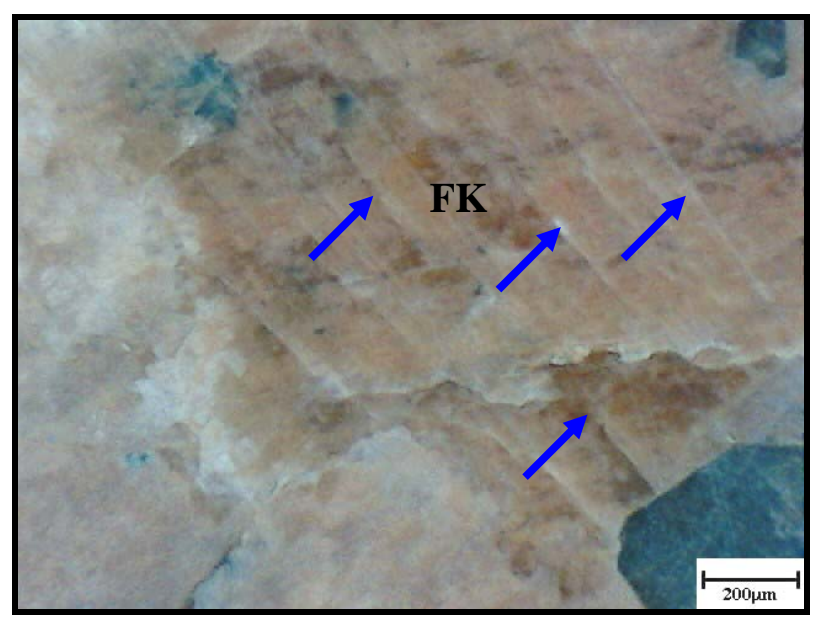

Figura 4.103 - Amostra do granito Vermelho Brasília submetido a solicitações de desgaste com abrasivo 1200 mesh. Notar a difícil visualização dos riscos feitos pelo abrasivo e os planos de clivagem do feldspato potássico (seta azul).

Da fase anterior para esta, poucas mudanças ocorreram no perfil de rugosidade do granito Cinza Castelo. $\mathrm{O} \mathrm{R}_{\max }$ permaneceu na casa dos 100 microns e a quantidade de vales mais pronunciados permaneceu constante (Figura 4.104). As principais descontinuidades são 
microfissuras encontradas principalmente nos cristais de feldspatos plagioclásio (Figura 4.105).

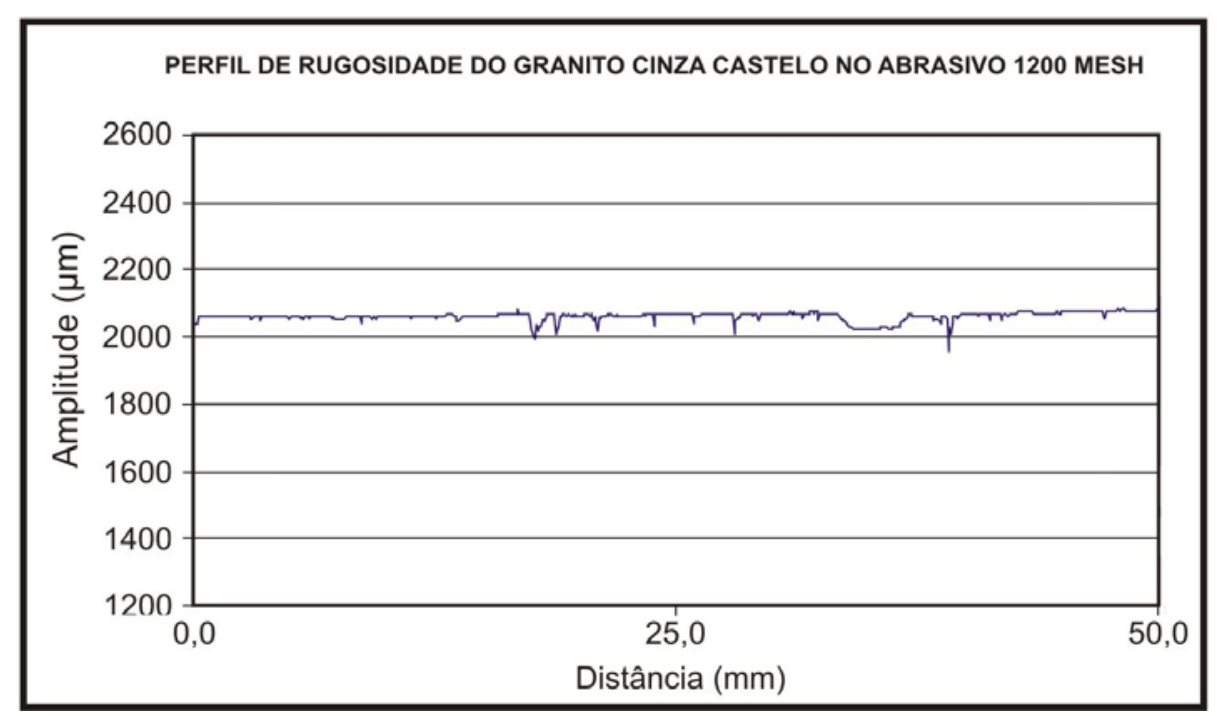

Figura 4.104 - Rugosidade do granito Cinza Castelo na nona etapa de desgaste.

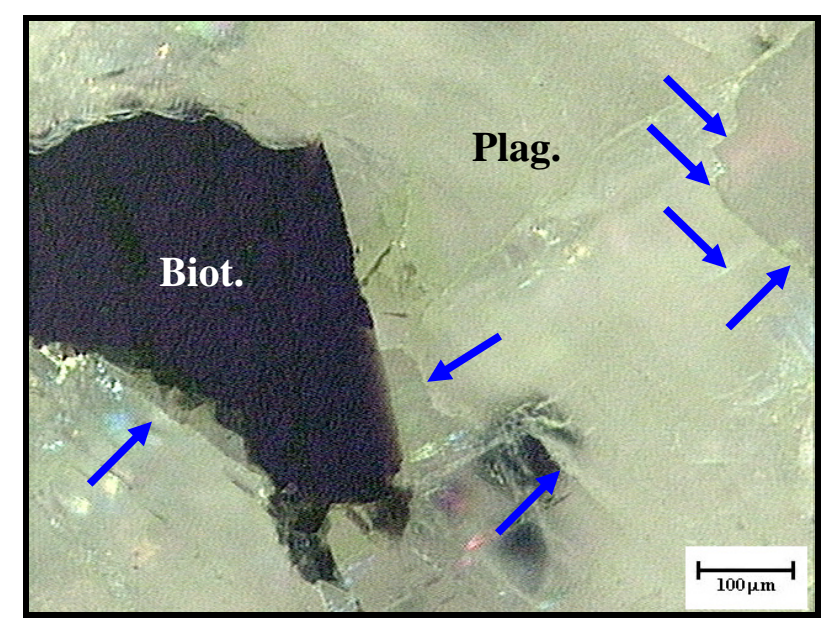

Figura 4.105 - Amostra do granito Cinza Castelo submetido a solicitações de desgaste com abrasivo 1200 mesh. Notar ocorrência de microfissuras intragrão (seta azul).

Nesta etapa o "granito" Desert Storm também não apresentou muitas mudanças no seu perfil de rugosidade, permanecendo o $\mathrm{R}_{\max }$ com 100 microns (Figura 4.106). Microfissuras intragrão preenchidas por epidoto foram as principais descontinuidades encontradas na rocha (Figura 4.107). 


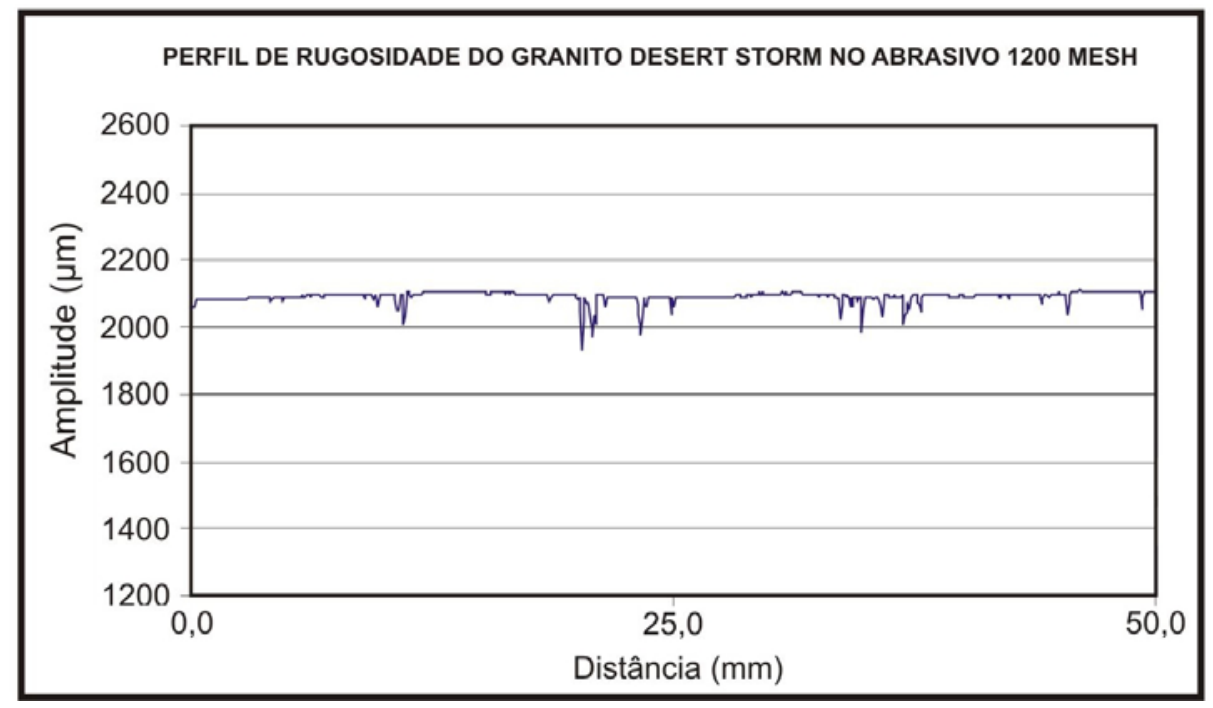

Figura 4.106 - Rugosidade do “granito” Desert Storm na nona etapa de desgaste.

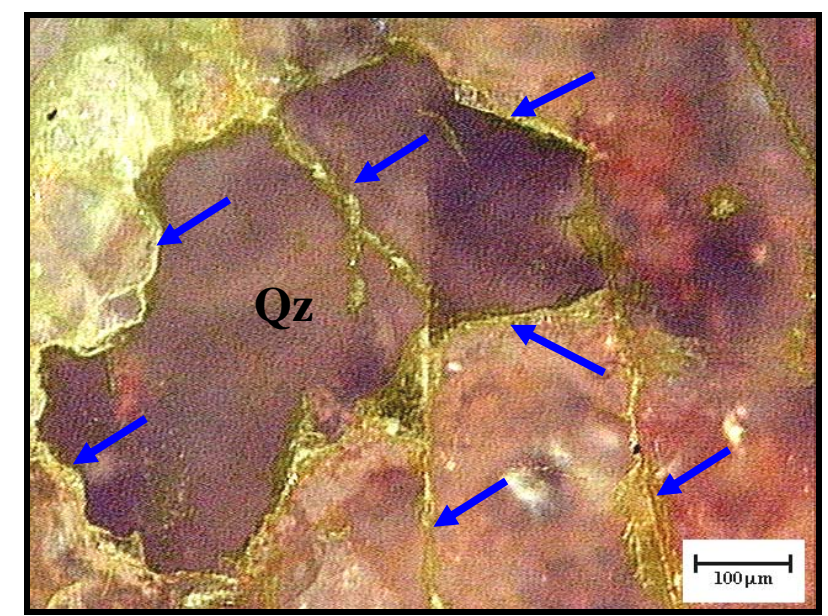

Figura 4.107 - Amostra do "granito” Desert Storm submetido a solicitações de desgaste com abrasivo 1200 mesh. Notar ocorrência de microfissuras intragrão (seta azul).

Na nona etapa de desgaste o "granito" Verde Labrador foi o único que mostrou uma sensível melhora no seu perfil de rugosidade, apresentando na maior sua parte superfície praticamente plana (Figura 4.108). A poucas descontinuidades encontradas são devido a presença de microfissuras intragrão (Figura 4.109). 


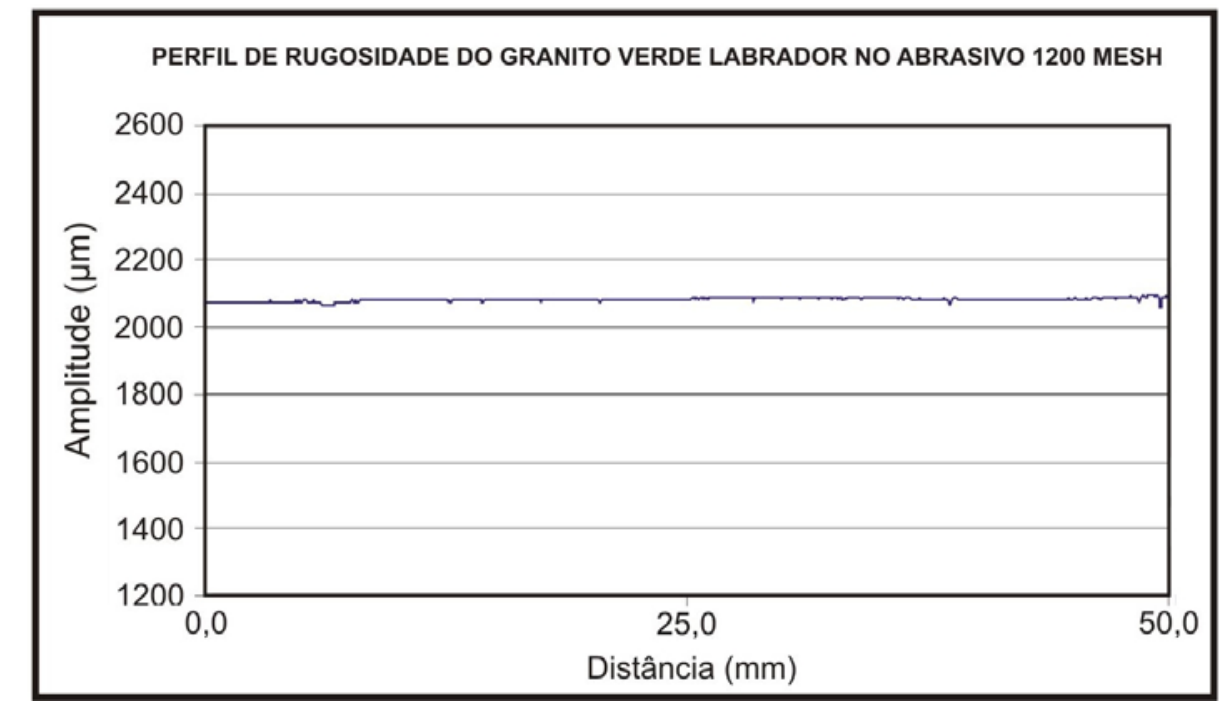

Figura 4.108 - Rugosidade do "granito” Verde Labrador na nona etapa de desgaste.

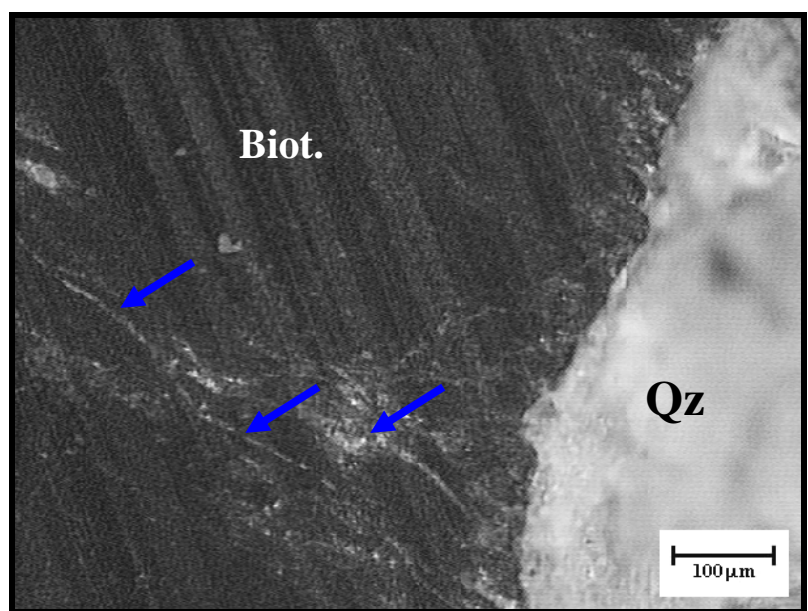

Figura 4.109 - Amostra do "granito" Verde Labrador submetido a solicitações de desgaste com abrasivo 1200 mesh. Notar ocorrência de microfissuras intragrão (seta azul).

O granito Vermelho Capão Bonito apresentou uma piora no seu perfil de rugosidade, possivelmente devido ao desenvolvimento de microfissuras não existentes anteriormente. $\mathrm{O} \mathrm{R}_{\max }$ atingiu, em alguns pontos, 200 microns (Figura 4.110). É possível verificar também o desenvolvimento de um leve erro de forma ao longo do perfil, o que corrobora a possibilidade do desenvolvimento de novas descontinuidades nesta etapa. Microfissuras intragrão são encontradas em cristais de biotita acompanhando o sentido da borda do mineral, bem como microfissuras intergrão (Figura 4.111). 


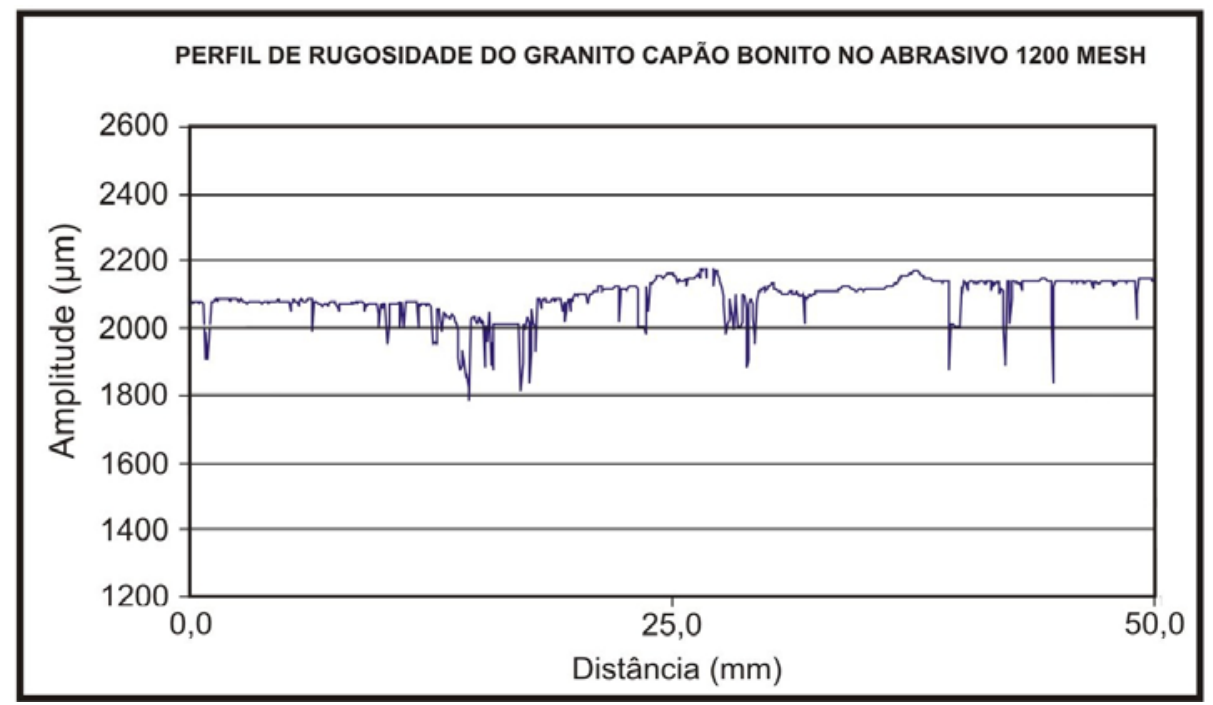

Figura 4.110 - Rugosidade do granito Vermelho Capão Bonito na nona etapa de desgaste.

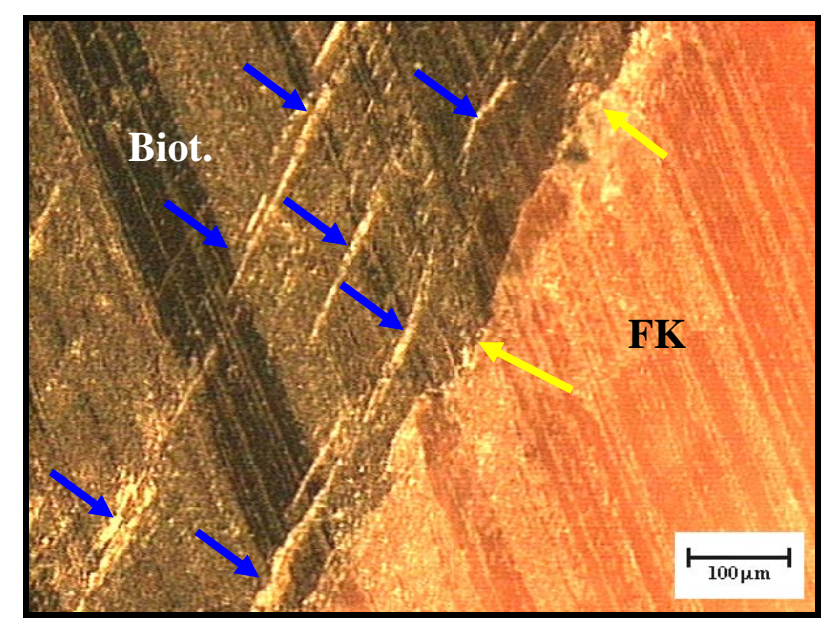

Figura 4.111 - Amostra do granito Vermelho Capão Bonito submetido a solicitações de desgaste com abrasivo 1200 mesh. Notar ocorrência de microfissuras intragrão (seta azul) e intergrão (seta amarela).

A etapa 1200 mesh não apresentou uma contribuição efetiva para a melhoria da rugosidade em pelo menos três materiais estudados, sendo que o granito Vermelho Capão Bonito apresentou uma piora na sua superfície. Cabe ressaltar que tal piora verificada não se deve ao abrasivo propriamente dito, mas sim ao sistema operacional utilizado que gerou o desenvolvimento de novas micro-descontinuidades, confirmadas pelo desenvolvimento de erros de forma. 


\subsubsection{DÉCIMA ETAPA (LUSTRO)}

Desde o início até o final do polimento se estima que cerca de 1000 microns $(1 \mathrm{~mm})$ da espessura da rocha seja desgastada. Isto explica a diminuição da rugosidade de contatos ao longo das etapas de polimento.

A fase de lustro se caracteriza por ser a única que não utiliza abrasivos magnesianos, mas sim abrasivos à base de alumina $\left(\mathrm{Al}_{2} \mathrm{O}_{3}\right)$. Esta fase tem por objetivo principal ressaltar o brilho da superfície que foi desgastada até então e, secundariamente, diminuir ainda mais a rugosidade.

O corpo-de-prova do "granito" Preto Indiano mostrou uma rugosidade de contatos muito baixa. Com exceção de um ponto que apresentou rugosidade de contato de 300 microns, a maioria dos minerais apresentou rugosidade na ordem de 50 microns (Figura 4.112). Um fato ocorrido nesta etapa é a presença pequenos picos no intervalo da rugosidade mineral. Essa observação é justificada pelo fato de ocorrer um desenvolvimento considerável de microfissuras intragrão, principalmente nos minerais de granada e quartzo (Figura 4.113), minerais que apresentam fraturas minerais. Para esse caso, especificamente, poderia ser dada uma carga de menor intensidade no cabeçote visando a minoração dessas trincas.

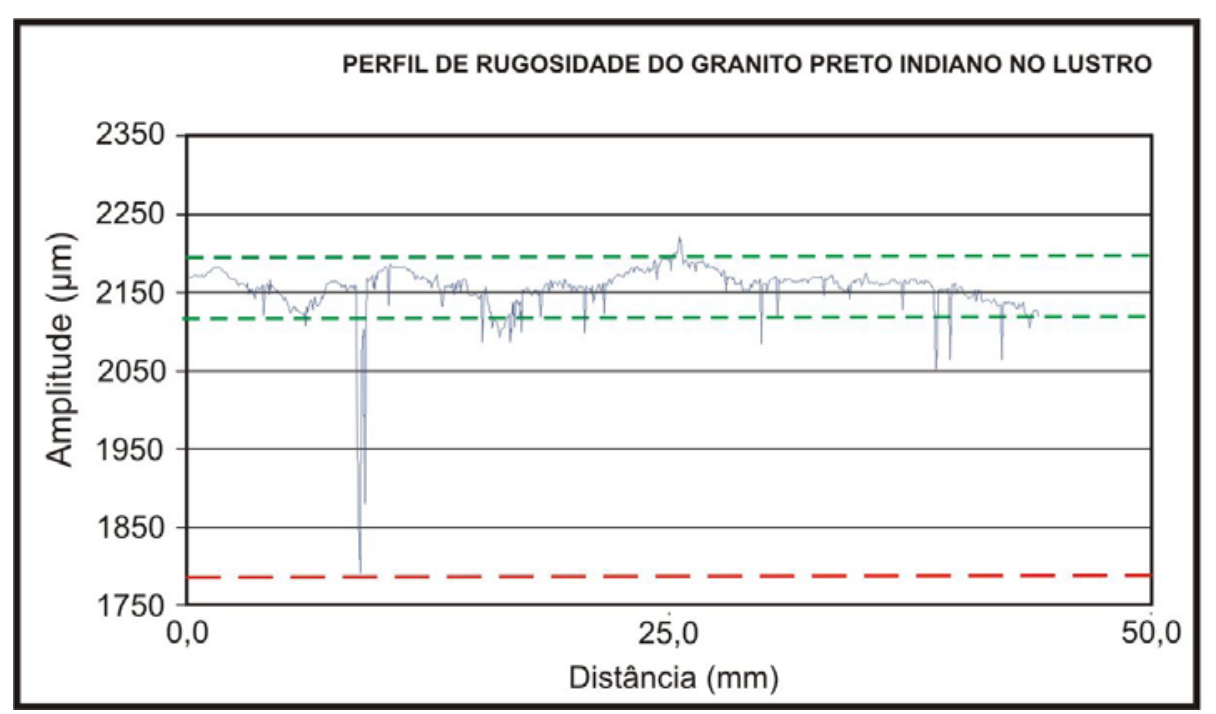

Figura 4.112 - Rugosidade do "granito” Preto Indiano na décima etapa de desgaste. Notar o desenvolvimento de picos na zona de rugosidade mineral. 


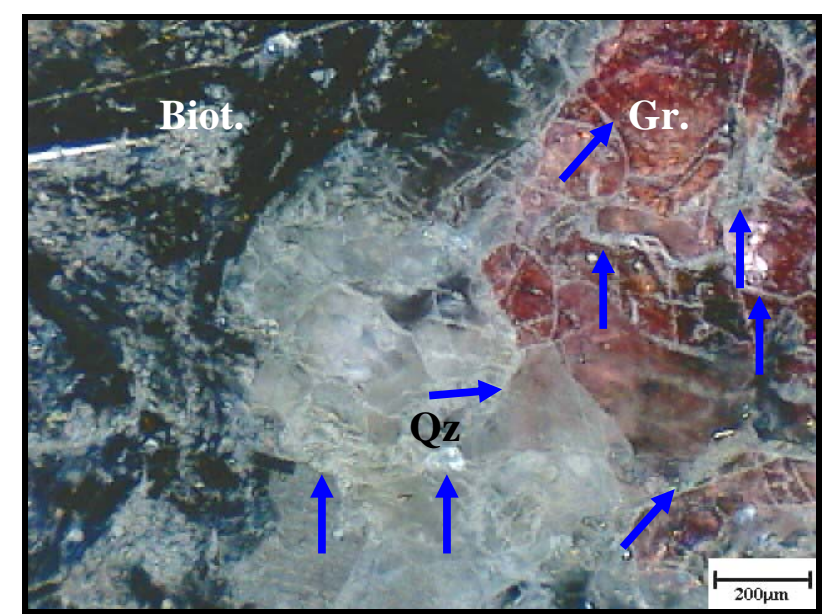

Figura 4.113 - Amostra do “granito” Preto Indiano na décima etapa de desgaste. Notar o intenso trincamento nos cristais de granada e quartzo (seta azul).

Na última etapa de desgaste, o granito Vermelho Brasília apresentou rugosidade mineral na ordem de 50 microns (Figura 4.114), mostrando um fechamento razoável entre os minerais nesta fase, embora seja possível verificar presença de microfissuras intragrão e intergrão (Figura 4.115). Devido a algum problema operacional, como por exemplo, a diminuição no fornecimento de água ao sistema ou a quebra de alguma porção do rebolo abrasivo, alguns riscos são visíveis na superfície de alguns cristais (Figura 4.116).

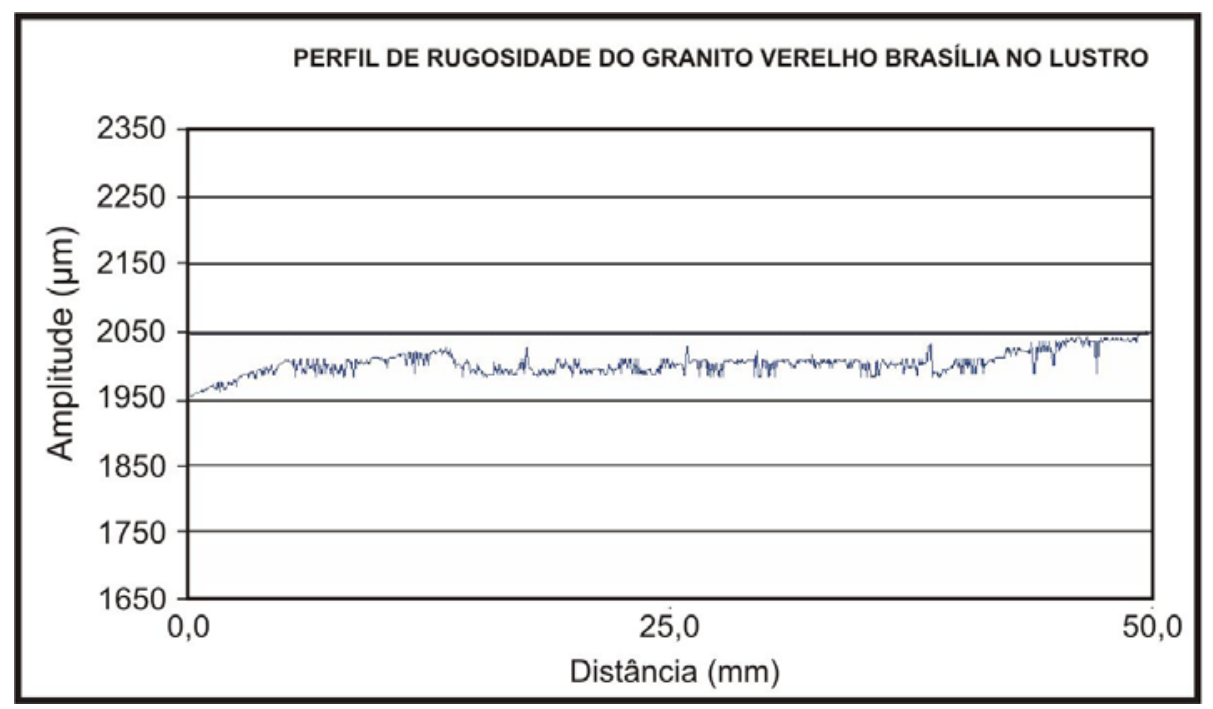

Figura 4.114 - Rugosidade do granito Vermelho Brasília na décima etapa de desgaste. 


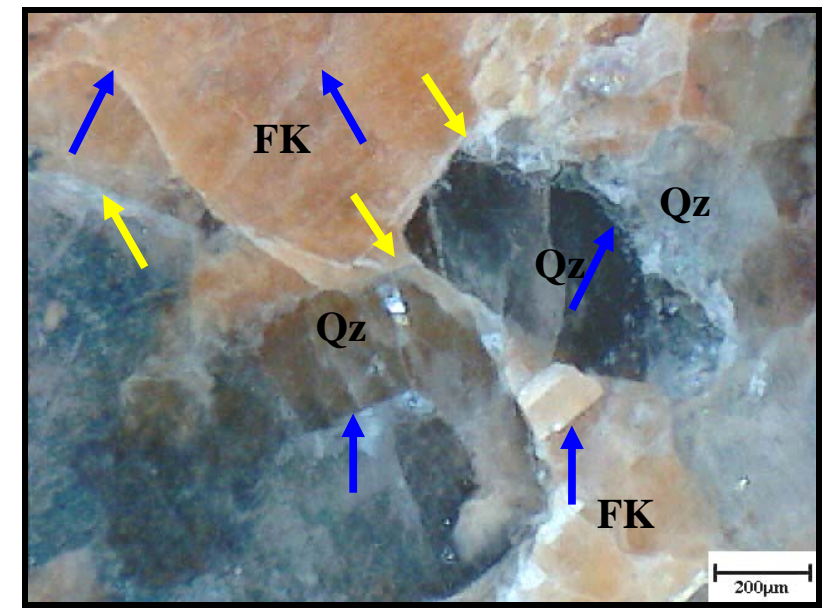

Figura 4.115 - Amostra do granito Vermelho Brasília submetido a solicitações de desgaste com abrasivo de lustro, mostrando alguns trincamentos de borda (seta amarela) e no interior dos minerais (seta azul).

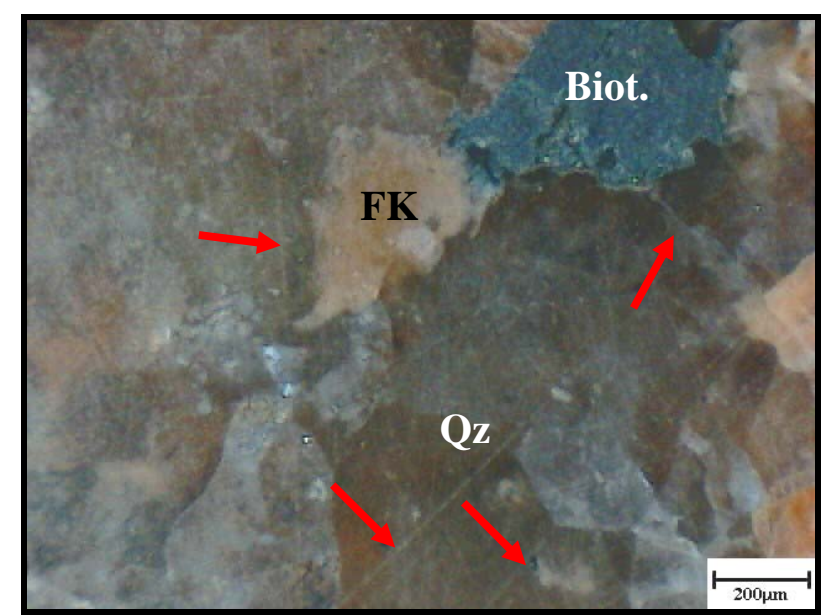

Figura 4.116 - Visão do granito Vermelho Brasília submetido ao lustro com alguns cristais riscados (seta vermelha).

$\mathrm{Na}$ última etapa de polimento o granito Cinza Castelo não apresentou muitas mudanças em relação às duas fases anteriores, mostrando um $R_{\max }$ de 50 microns e com boa porção de seu perfil mostrando pequenas variações (Figura 4.117). As maiores descontinuidades são representadas por poucas microfissuras intragrão e intergrão (Figura 4.118). 


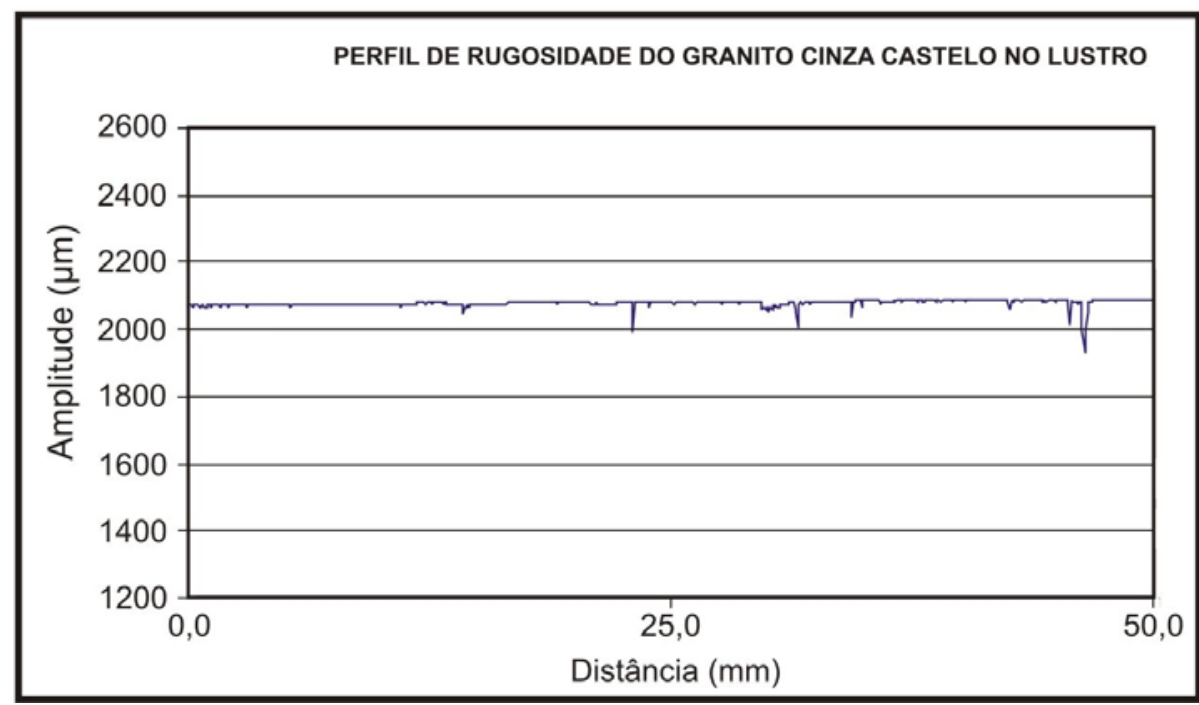

Figura 4.117 - Rugosidade do granito Cinza Castelo na décima etapa de desgaste.

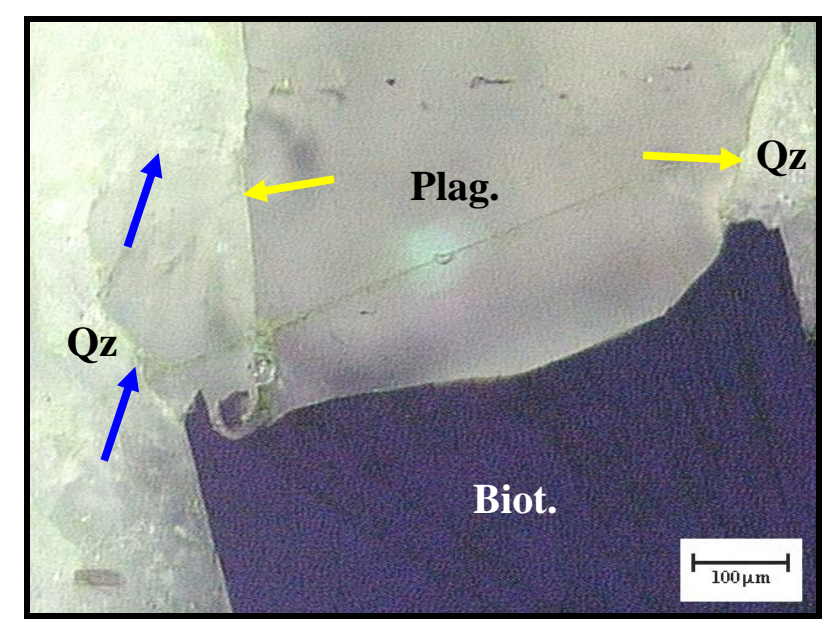

Figura 4.118 - Amostra do granito Cinza Castelo submetido a solicitações de desgaste com abrasivo de lustro. Notar existência de microfissuras intragrão (seta azul) e intergrão (seta amarela).

O "granito" Desert Storm não apresentou mudança em seu perfil de rugosidade em relação à nona etapa de polimento. $\mathrm{O} \mathrm{R}_{\max }$ foi, na maioria dos casos, de 50 microns (Figura 4.119). As principais descontinuidades encontradas foram as microfissuras intragrão preenchidas por epidoto (Figura 4.120). 


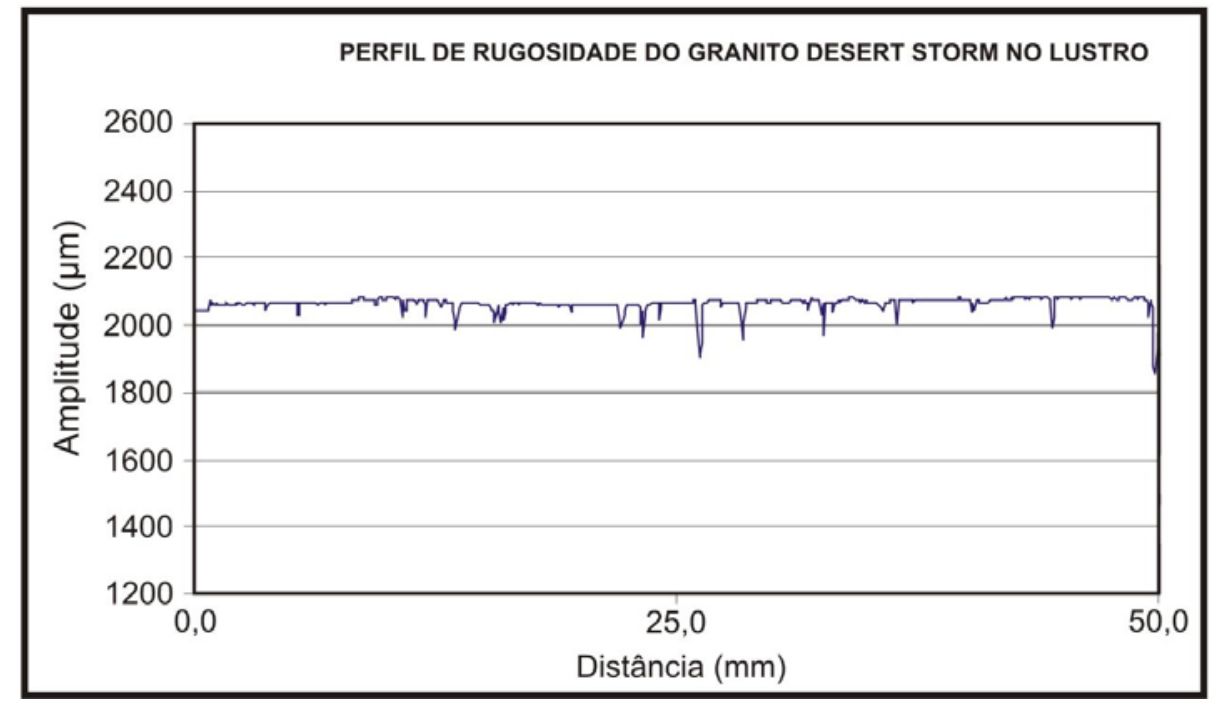

Figura 4.119 - Rugosidade do "granito" Desert Storm na décima etapa de desgaste.

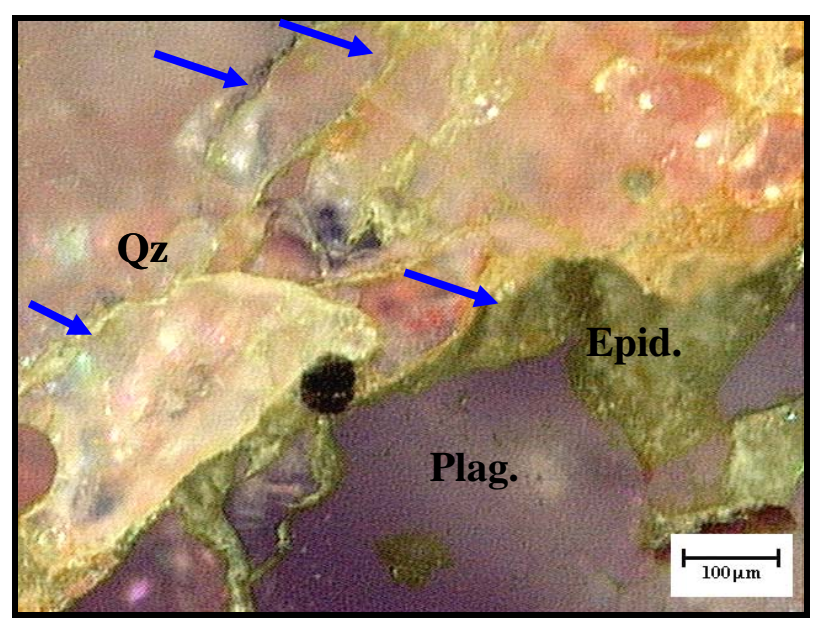

Figura 4.120 - Amostra do “granito” Desert Storm submetido a solicitações de desgaste com abrasivo de lustro. Notar existência de microfissuras intragrão (seta azul).

O "granito" Verde Labrador manteve o bom padrão de rugosidade encontrado na etapa anterior. $\mathrm{O} \mathrm{R}_{\max }$ chegou aos 50 microns (Figura 4.121). As principais descontinuidades foram leves riscos deixados pelo abrasivo e algumas microfissuras intragrão e intergrão (Figura 4.122). 


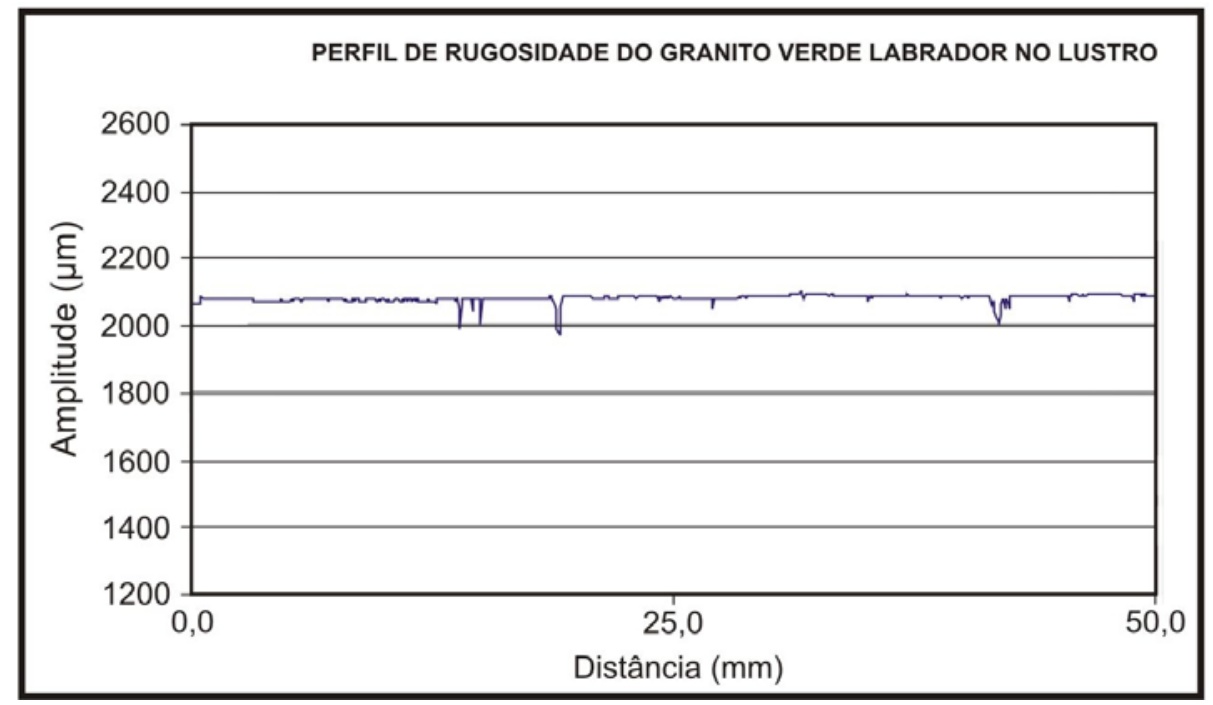

Figura 4.121 - Rugosidade do “granito” Verde Labrador na décima etapa de desgaste.

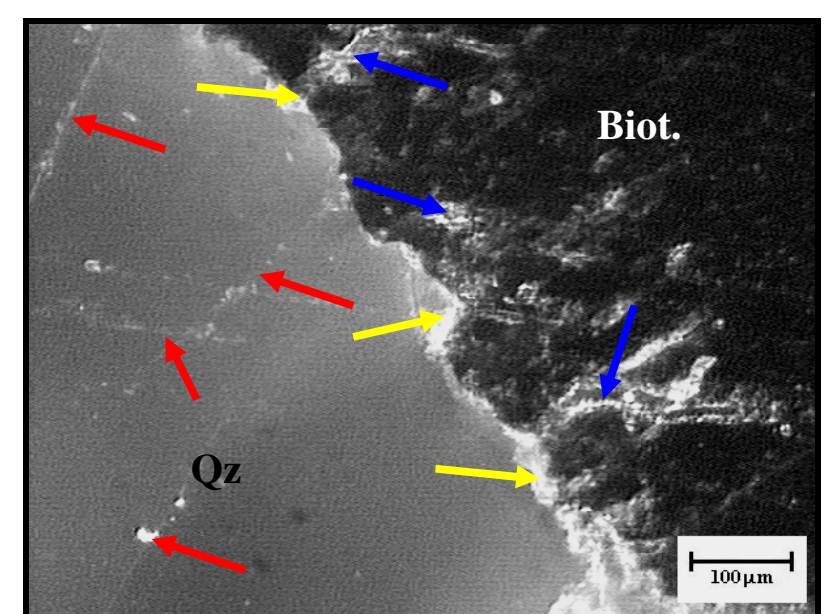

Figura 4.122 - Visão do "granito" Verde Labrador submetido ao lustro com alguns cristais riscados (seta vermelha) pelo abrasivo e microfissuras intragrão (seta azul) e intergrão (seta amarela).

$\mathrm{Na}$ última etapa de polimento o granito Vermelho Capão Bonito apresentou uma melhora no perfil de rugosidade, mostrando $\mathrm{R}_{\max }$ de 100 microns e algumas porções planas, indicando bom acabamento (Figura 4.123). As descontinuidades encontradas foram alguns fragmentos de quartzo retirados nas proximidades de contato com cristais de biotita, o que leva inferir desgaste por freetting, que é a forma de desgaste por repetição de esforços em local fixo, fazendo com que ocorra o arrancamento de material (Figura 4.124). 


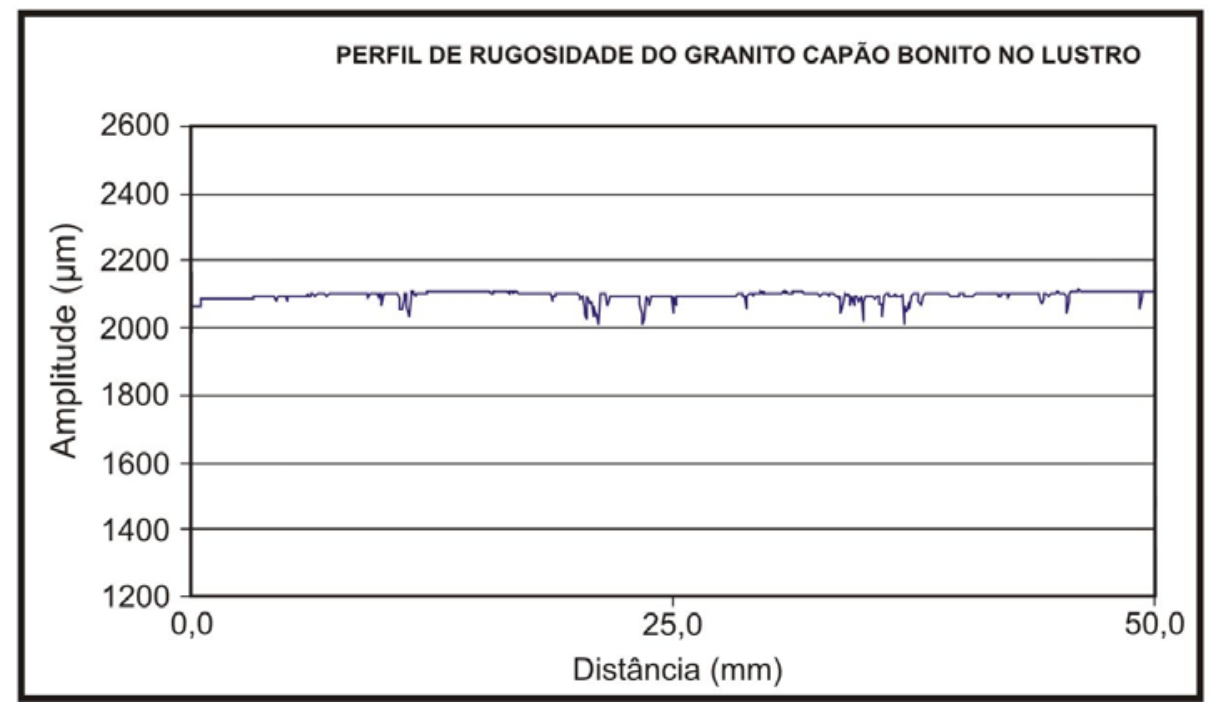

Figura 4.123 - Rugosidade do granito Vermelho Capão Bonito na décima etapa de desgaste.

Figura 4.124 - Amostra do granito Vermelho Capão Bonito submetido a solicitações de desgaste com abrasivo de lustro. Notar ocorrência de microfissuras intergrão (seta amarela).

\subsection{MEDIÇÃO DO BRILHO DOS MATERIAIS ESTUDADOS}

Nas amostras coletadas na empresa Granita que foram submetidas à determinação da rugosidade superficial, processou-se a medição do brilho, com o objetivo de obter uma informação indireta da qualidade da superfície polida. A medição foi realizada com um medidor de brilho (Glossmeter) de propriedade do Laboratório de Caracterização Tecnológica de Rochas Ornamentais da Universidade Estadual Paulista (UNESP) Campus Rio Claro. 
Foi utilizada a média de treze leituras de brilho efetuadas em cada amostra de rocha, de acordo com o esquema apresentado na Figura 4.125 e ilustrado nas Figuras 4.126 e 4.127.

\begin{tabular}{|lll|}
\hline 1 & 5 & 10 \\
2 & 6 & 11 \\
3 & 7 & 12 \\
4 & 8 & \\
& 9 & 13 \\
\hline
\end{tabular}

Figura 4.125 - Disposição dos pontos de leitura do brilho nos corpos-de-prova submetidos ao polimento industrial.

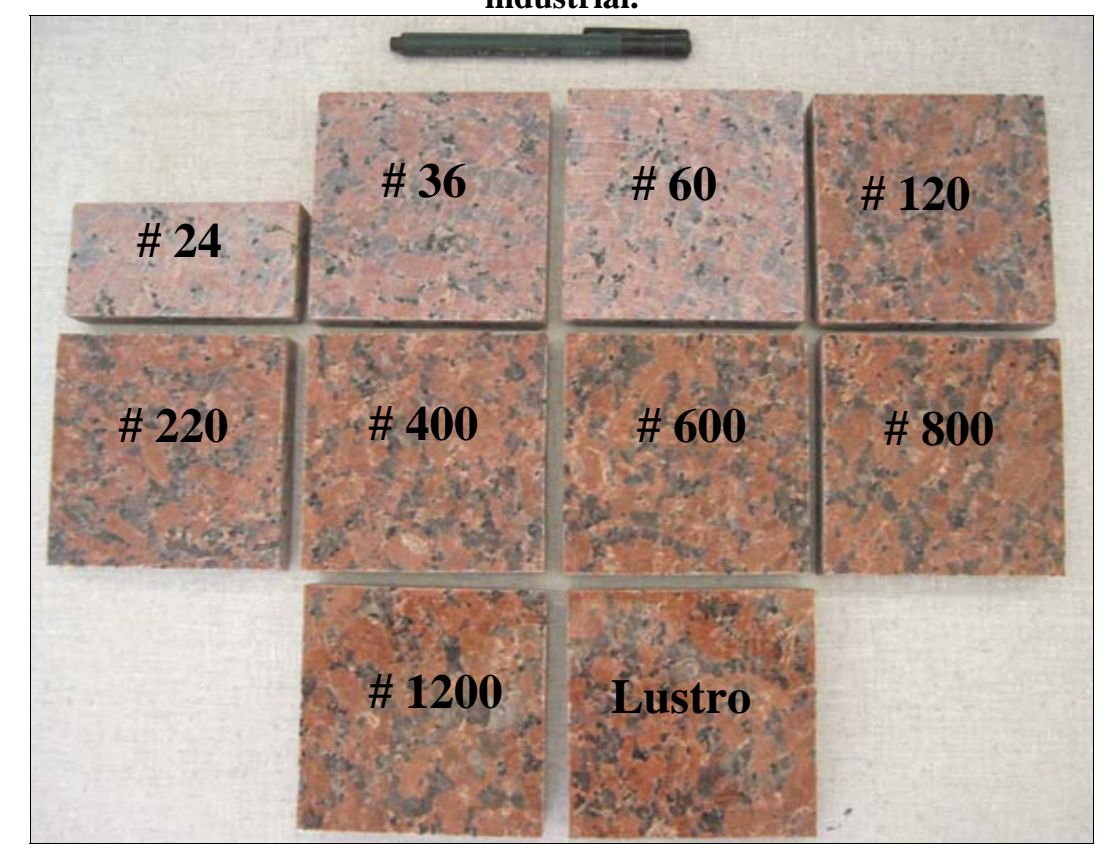

Figura 4.126 - Exemplo dos corpos-de-prova utilizados para a medição do brilho nas diferentes etapas de desgaste.

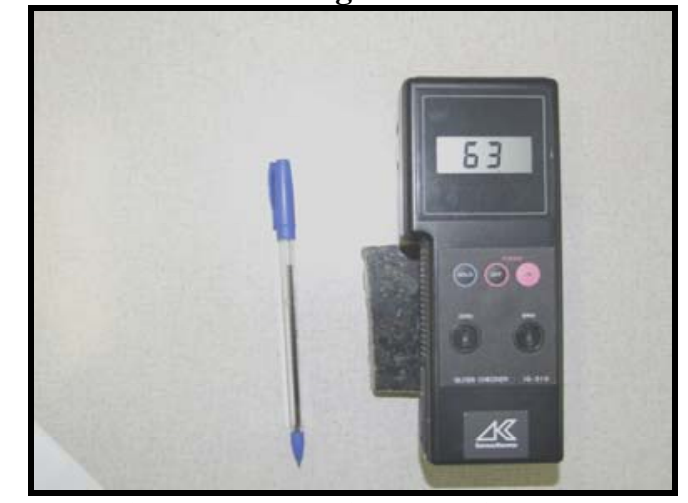

Figura 4.127 - Procedimento de medida do brilho nas amostras estudadas.

Os valores de brilho medidos nas rochas estudadas são apresentados nas tabelas a seguir (Tabelas 4.1 a 4.6). 
TABELA 4.1 - Valores de brilho obtidos nas amostras do granito Vermelho Brasília (VB).

\begin{tabular}{|c|c|c|c|c|c|c|c|c|c|c|c|c|c|c|}
\hline \multirow{2}{*}{$\begin{array}{c}\text { AMOSTRA } \\
\text { VB-24 }\end{array}$} & \multicolumn{13}{|c|}{ VALORES DE BRILHO } & \multirow{2}{*}{$\begin{array}{c}\text { MÉDIA } \\
0\end{array}$} \\
\hline & 0 & 0 & 0 & 0 & 0 & 0 & 0 & 0 & 0 & 0 & 0 & 0 & 0 & \\
\hline VB-36 & 0 & 0 & 0 & 0 & 0 & 0 & 0 & 0 & 0 & 0 & 0 & 0 & 0 & 0 \\
\hline VB-60 & 0 & 0 & 0 & 0 & 0 & 0 & 0 & 0 & 0 & 0 & 0 & 0 & 0 & 0 \\
\hline VB-120 & 1 & 1 & 1 & 1 & 0 & 1 & 0 & 0 & 1 & 1 & 1 & 2 & 0 & 0,77 \\
\hline VB-220 & 2 & 3 & 3 & 3 & 2 & 2 & 4 & 4 & 3 & 2 & 1 & 2 & 1 & 2,46 \\
\hline VB-400 & 10 & 8 & 8 & 5 & 4 & 7 & 11 & 8 & 9 & 11 & 10 & 3 & 9 & 7,92 \\
\hline VB-600 & 34 & 38 & 32 & 37 & 32 & 34 & 36 & 32 & 31 & 35 & 36 & 29 & 37 & 34,01 \\
\hline VB-800 & 50 & 46 & 41 & 43 & 46 & 50 & 51 & 49 & 52 & 56 & 55 & 52 & 45 & 48,92 \\
\hline VB-1200 & 70 & 72 & 68 & 72 & 62 & 75 & 72 & 72 & 61 & 61 & 71 & 73 & 68 & 63,54 \\
\hline LUSTRO & 72 & 71 & 76 & 75 & 79 & 77 & 80 & 80 & 79 & 79 & 76 & 79 & 74 & 76,70 \\
\hline
\end{tabular}


TABELA 4.2 - Valores de brilho obtidos nas amostras do “granito” Preto Indiano (PI).

\begin{tabular}{|c|c|c|c|c|c|c|c|c|c|c|c|c|c|c|}
\hline AMOSTRA & \multicolumn{13}{|c|}{ VALORES DE BRILHO } & \multirow{2}{*}{$\begin{array}{c}\text { MÉDIA } \\
0\end{array}$} \\
\hline PI-24 & 0 & 0 & 0 & 0 & 0 & 0 & 0 & 0 & 0 & 0 & 0 & 0 & 0 & \\
\hline PI-36 & 0 & 0 & 0 & 0 & 0 & 0 & 0 & 0 & 0 & 0 & 0 & 0 & 0 & 0 \\
\hline PI-60 & 0 & 0 & 0 & 0 & 0 & 0 & 0 & 0 & 0 & 0 & 0 & 0 & 0 & 0 \\
\hline PI-120 & 0 & 0 & 0 & 0 & 0 & 0 & 0 & 0 & 0 & 0 & 0 & 0 & 0 & 0 \\
\hline PI-220 & 1 & 3 & 1 & 3 & 2 & 2 & 2 & 2 & 1 & 2 & 1 & 1 & 1 & 1,69 \\
\hline PI-400 & 11 & 8 & 9 & 10 & 10 & 8 & 7 & 7 & 7 & 6 & 5 & 4 & 7 & 7,62 \\
\hline PI-600 & 18 & 18 & 25 & 23 & 32 & 26 & 22 & 26 & 26 & 23 & 27 & 20 & 19 & 23,46 \\
\hline PI-800 & 45 & 45 & 40 & 40 & 41 & 40 & 44 & 42 & 45 & 43 & 48 & 42 & 41 & 42,77 \\
\hline PI-1200 & 64 & 66 & 62 & 61 & 67 & 58 & 63 & 65 & 66 & 57 & 61 & 64 & 66 & 63,08 \\
\hline LUSTRO & 79 & 78 & 76 & 74 & 73 & 72 & 75 & 75 & 79 & 73 & 71 & 73 & 74 & 74,77 \\
\hline
\end{tabular}


TABELA 4.3 - Valores de brilho obtidos nas amostras do granito Cinza Castelo (CC).

AMOSTRA

VALORES DE BRILHO

MÉDIA

\begin{tabular}{|l|c|c|c|c|c|c|c|c|c|c|c|c|c|c|}
\hline & \multicolumn{9}{|c|}{} \\
\hline CC-24 & 0 & 0 & 0 & 0 & 0 & 0 & 0 & 0 & 0 & 0 & 0 & 0 & 0 & 0 \\
\hline CC-36 & 0 & 0 & 0 & 0 & 0 & 0 & 0 & 0 & 0 & 0 & 0 & 0 & 0 & 0 \\
\hline CC-60 & 0 & 0 & 0 & 0 & 0 & 0 & 0 & 0 & 0 & 0 & 0 & 0 & 0 & 0 \\
\hline CC-120 & 0 & 0 & 0 & 0 & 0 & 0 & 0 & 0 & 0 & 0 & 0 & 0 & 0 & 0 \\
\hline CC-220 & 2 & 2 & 1 & 1 & 1 & 2 & 2 & 1 & 1 & 1 & 2 & 1 & 1 & 1,38 \\
\hline CC-400 & 14 & 12 & 11 & 11 & 13 & 8 & 10 & 10 & 11 & 10 & 9 & 8 & 9 & 10,46 \\
\hline CC-600 & 21 & 20 & 19 & 20 & 20 & 22 & 23 & 23 & 23 & 22 & 21 & 21 & 23 & 21,38 \\
\hline CC-800 & 43 & 46 & 45 & 45 & 43 & 43 & 41 & 39 & 36 & 37 & 39 & 42 & 37 & 41,23 \\
\hline CC-1200 & 57 & 55 & 54 & 55 & 55 & 59 & 58 & 59 & 57 & 58 & 56 & 58 & 55 & 56,62 \\
\hline & 68 & 69 & 71 & 66 & 68 & 68 & 69 & 70 & 70 & 69 & 68 & 69 & 71 & 68,92 \\
\hline
\end{tabular}


TABELA 4.4-Valores de brilho obtidos nas amostras do "granito” Desert Storm (DS).

AMOSTRA

VALORES DE BRILHO

MÉDIA

\begin{tabular}{|c|c|c|c|c|c|c|c|c|c|c|c|c|c|c|}
\hline DS-24 & 0 & 0 & 0 & 0 & 0 & 0 & 0 & 0 & 0 & 0 & 0 & 0 & 0 & 0 \\
\hline DS-36 & 0 & 0 & 0 & 0 & 0 & 0 & 0 & 0 & 0 & 0 & 0 & 0 & 0 & 0 \\
\hline DS-60 & 0 & 0 & 0 & 0 & 0 & 0 & 0 & 0 & 0 & 0 & 0 & 0 & 0 & 0 \\
\hline DS-120 & 0 & 0 & 0 & 0 & 0 & 0 & 0 & 0 & 0 & 0 & 0 & 0 & 0 & 0 \\
\hline DS-220 & 2 & 2 & 1 & 1 & 1 & 2 & 1 & 1 & 2 & 2 & 1 & 2 & 1 & 1,46 \\
\hline DS-400 & 11 & 12 & 13 & 10 & 8 & 8 & 8 & 9 & 13 & 9 & 10 & 6 & 8 & 9,61 \\
\hline DS-600 & 29 & 31 & 34 & 35 & 32 & 29 & 30 & 29 & 31 & 36 & 32 & 31 & 28 & 31,23 \\
\hline DS-800 & 51 & 49 & 46 & 44 & 50 & 43 & 39 & 41 & 56 & 49 & 47 & 49 & 48 & 47,08 \\
\hline DS-1200 & 66 & 68 & 69 & 68 & 67 & 65 & 66 & 66 & 66 & 70 & 67 & 64 & 66 & 66,80 \\
\hline LUSTRO & 72 & 74 & 74 & 74 & 71 & 78 & 72 & 69 & 65 & 78 & 76 & 74 & 71 & 72,93 \\
\hline
\end{tabular}


TABELA 4.5 - Valores de brilho obtidos nas amostras do "granito" Verde Labrador (VL).

AMOSTRA

VALORES DE BRILHO

MÉDIA

\begin{tabular}{|c|c|c|c|c|c|c|c|c|c|c|c|c|c|c|}
\hline VL-24 & 0 & 0 & 0 & 0 & 0 & 0 & 0 & 0 & 0 & 0 & 0 & 0 & 0 & 0 \\
\hline VL-36 & 0 & 0 & 0 & 0 & 0 & 0 & 0 & 0 & 0 & 0 & 0 & 0 & 0 & 0 \\
\hline VL-60 & 0 & 0 & 0 & 0 & 0 & 0 & 0 & 0 & 0 & 0 & 0 & 0 & 0 & 0 \\
\hline VL-120 & 0 & 0 & 0 & 0 & 0 & 0 & 0 & 0 & 0 & 0 & 0 & 0 & 0 & 0 \\
\hline VL-220 & 1 & 2 & 2 & 1 & 2 & 1 & 1 & 2 & 1 & 1 & 2 & 1 & 2 & 1,46 \\
\hline VL-400 & 11 & 10 & 10 & 14 & 12 & 11 & 12 & 11 & 14 & 16 & 13 & 12 & 16 & 12,46 \\
\hline VL-600 & 27 & 32 & 33 & 27 & 33 & 25 & 25 & 26 & 31 & 33 & 37 & 30 & 32 & 30,85 \\
\hline VL-800 & 60 & 56 & 55 & 57 & 58 & 60 & 58 & 59 & 63 & 66 & 64 & 66 & 59 & 60,08 \\
\hline VL-1200 & 65 & 60 & 59 & 64 & 67 & 63 & 67 & 66 & 64 & 70 & 68 & 65 & 64 & 64,77 \\
\hline LUSTRO & 74 & 76 & 79 & 81 & 82 & 81 & 80 & 77 & 78 & 80 & 81 & 81 & 83 & 79,46 \\
\hline
\end{tabular}


TABELA 4.6 - Valores de brilho obtidos nas amostras do granito Vermelho Capão Bonito (CB).

AMOSTRA

VALORES DE BRILHO

MÉDIA

\begin{tabular}{|c|c|c|c|c|c|c|c|c|c|c|c|c|c|c|}
\hline CB-24 & 0 & 0 & 0 & 0 & 0 & 0 & 0 & 0 & 0 & 0 & 0 & 0 & 0 & 0 \\
\hline CB-36 & 0 & 0 & 0 & 0 & 0 & 0 & 0 & 0 & 0 & 0 & 0 & 0 & 0 & 0 \\
\hline CB-60 & 0 & 0 & 0 & 0 & 0 & 0 & 0 & 0 & 0 & 0 & 0 & 0 & 0 & 0 \\
\hline CB-120 & 0 & 0 & 0 & 0 & 0 & 0 & 0 & 0 & 0 & 0 & 0 & 0 & 0 & 0 \\
\hline CB-220 & 0 & 0 & 0 & 1 & 0 & 2 & 0 & 0 & 1 & 0 & 0 & 2 & 0 & 0,46 \\
\hline CB-400 & 7 & 5 & 8 & 10 & 9 & 8 & 8 & 6 & 5 & 6 & 5 & 4 & 7 & 6,77 \\
\hline CB-600 & 18 & 19 & 20 & 21 & 20 & 20 & 24 & 19 & 18 & 15 & 21 & 17 & 15 & 19,00 \\
\hline CB-800 & 33 & 30 & 30 & 35 & 32 & 31 & 29 & 28 & 31 & 35 & 29 & 27 & 30 & 30,77 \\
\hline CB-1200 & 49 & 49 & 47 & 51 & 51 & 49 & 47 & 51 & 50 & 50 & 53 & 49 & 46 & 49,38 \\
\hline LUSTRO & 61 & 62 & 65 & 62 & 62 & 62 & 63 & 59 & 68 & 57 & 56 & 55 & 51 & 60,23 \\
\hline
\end{tabular}


Comparando os resultados de brilho obtidos para os seis materiais (Figura 4.128), é possível constatar que aqueles que apresentam a combinação de menor quantidade de minerais transparentes com um perfil de rugosidade com menores irregularidades apresentam uma superfície com maior brilho. O "granito" Verde Labrador apresentou o maior brilho na maioria das etapas enquanto que o granito Vermelho Capão Bonito apresentou os piores resultados de brilho entre as seis rochas estudadas. Algumas considerações podem ser tiradas da comparação entre as rochas estudadas:

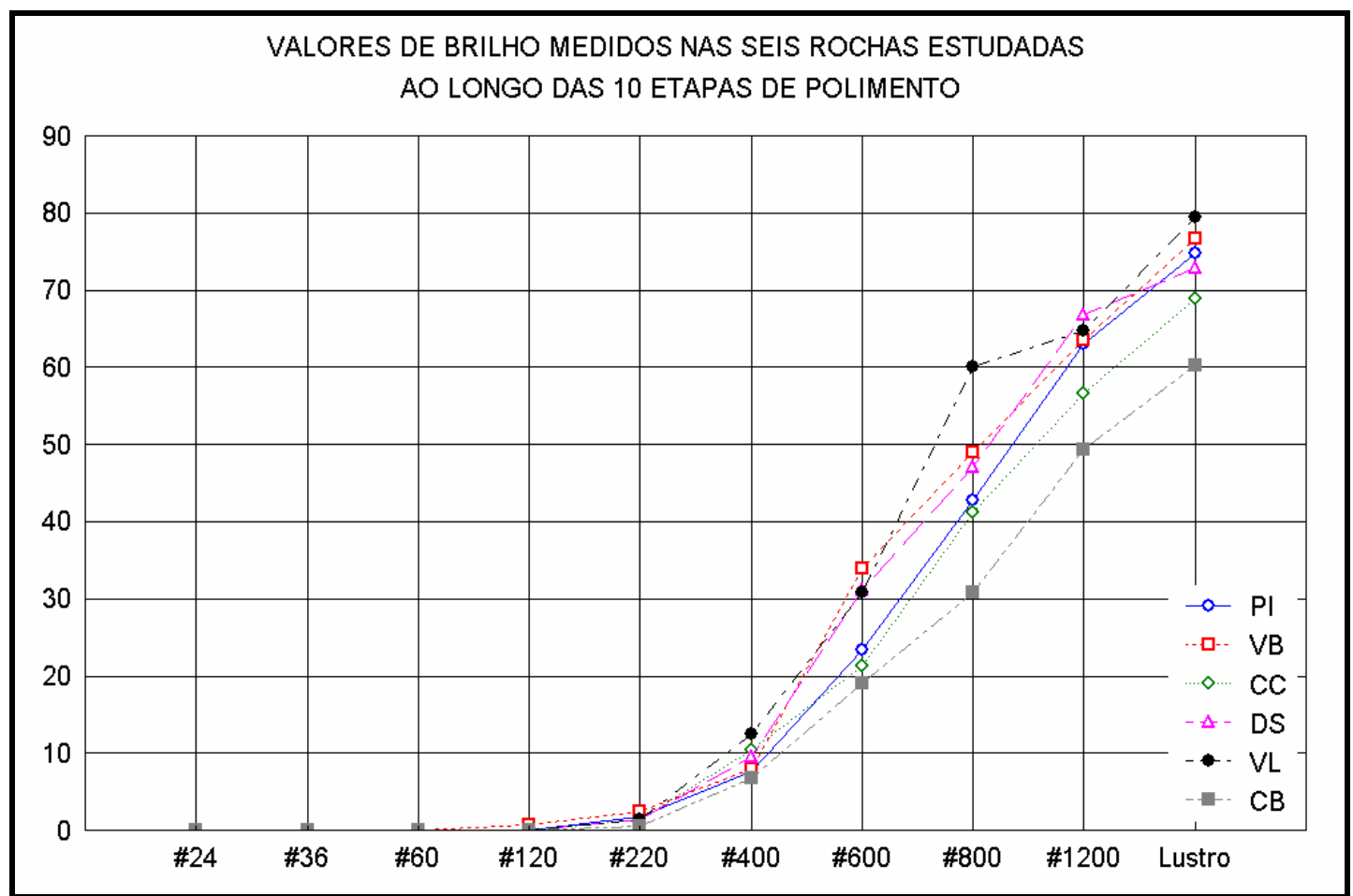

Figura 4.128 - Gráfico mostrando a comparação entre os resultados de brilho.

- O "granito" Preto Indiano, por apresentar conjuntamente duas características, quais sejam: quantidade maior de minerais brancos e translúcidos e faixas de bandamento mineral, o que respondem respectivamente, por refração de parcela da luz e reflexão de modo caótico dos feixes de luz, tende a ter valores de brilho inferiores;

- Praticamente em todos os materiais começaram a diferir em valores de brilho a partir do desgaste com o abrasivo \# 400 mesh (sexta etapa). Tais intervalos de granulometria, que 
seriam as fases intermediárias entre o levigamento e o lustro merecem ser estudadas com mais atenção;

- É possível que diferentes materiais apresentem momentos de desgaste ideais distintos para se processar a resinagem. Desta forma, o levigamento, definido pelo abrasivo \#120 mesh, pode não ser o mais indicado para todos os materiais. Tal etapa pode ser diferente, em função das características petrográficas da rocha.

- Ao longo de todas as etapas de polimento para os seis materiais estudados, a rugosidade mineral foi a que realmente apresentou diminuição, tendo a rugosidade de contatos, representadas pelas microfissuras intragrão e intergrão, apresentado pouca variação. O grau de anisotropia da rocha condiciona significativamente a rugosidade de contato. A tentativa de se efetuar o polimento visando a diminuição destes tipos de irregularidades é um passo importante para a melhoria da qualidade no beneficiamento secundário.

Os capítulos posteriores tratarão de cada elemento que compõe o tribossistema de maneira separada, mas sempre fazendo alusão, na medida que for necessária aos outros constituintes do sistema. 


\subsection{ENSAIO DE SIMULAÇÃO DE POLIMENTO DE ROCHA (SPR)}

\subsubsection{FUNDAMENTAÇÃO TEÓRICA}

Quando se estuda o polimento de um material rochoso, a medição dos parâmetros influentes na qualidade do produto final é condição imprescindível para uma real compreensão das interações entre as duas superfícies sólidas envolvidas, a rocha e o rebolo abrasivo.

$\mathrm{Na}$ Tribologia, existem várias formas de se medir a taxa de desgaste abrasivo $\left(\mathrm{W}^{0}\right)$; uma delas utiliza a equação de Zum Gahr (1987):

$$
W^{0}=\frac{\Delta W}{L \cdot A \cdot p} \quad \text { onde, }
$$

\footnotetext{
$\Delta \mathrm{W}$ - Massa perdida pelo desgaste;

L - Distância de contato;

A - Área aparente de desgaste;

$\mathrm{p}$ - Densidade do material removido.
}

Um modelo para medir o desgaste abrasivo de materiais com comportamento plástico (metais) foi desenvolvido por ZUM GAHR (op. cit.) com base nas diferentes interações entre a partícula abrasiva e o material desgastado.

A relação entre o volume de material perdido e o volume do sulco de desgaste produzido por uma partícula abrasiva é dada pela equação: 


$$
f a b=\frac{A v-(A 1+A 2)}{A v} \quad \text { onde, }
$$

Av - Área da seção de corte do sulco de desgaste;

$(\mathrm{A} 1+\mathrm{A} 2)$ - Quantidade de material que é deslocado para os lados do sulco por deformação plástica.

A Figura 4.129 mostra uma seção transversal de um sulco de desgaste produzido por uma partícula abrasiva.

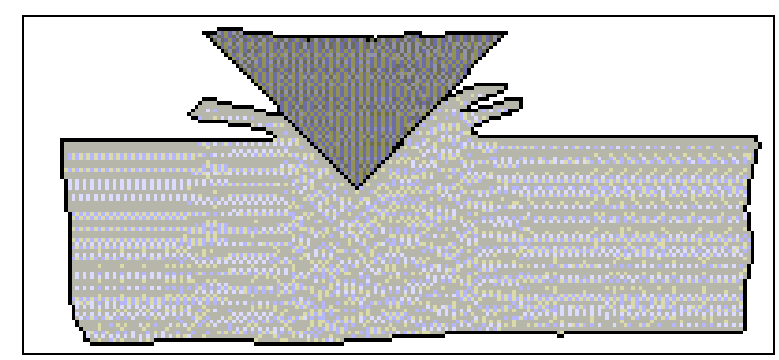

Figura 4.129 - Seção transversal de um sulco de desgaste produzido por uma partícula abrasiva (ZUM GAHR, 1987).

Para materiais não-plásticos (rochas, por exemplo), onde ocorre a remoção dos elementos constituintes por trincamento, o mesmo autor propôs:

$$
f a b=1+\frac{(A 1+A 2)}{A v}
$$

Em relação ao material rochoso propriamente dito, ocorrem determinadas peculiaridades no processo de desgaste verificado na etapa de polimento que não se tem um ensaio laboratorial que possa simulá-lo com fidelidade. Tal processo não pode ser medido em equipamentos convencionais para medição do desgaste em rocha, como por exemplo, o Amsler, pois este equipamento imprime uma condição muito severa de desgaste se comparada ao desgaste visando o polimento. Também ensaios do setor cerâmico que verificam a 
resistência ao desgaste destes materiais não são indicados, pois, como o anterior, não refletem as condições de contorno verificadas no beneficiamento secundário de rochas ornamentais. Além disso, tais equipamentos trabalham com abrasivos livres, configurando, segundo Zum Gahr (1987) um contato do tipo a 3 corpos, enquanto que o tipo de desgaste que ocorre na etapa de polimento é a 2 corpos. Diante de tal constatação, viu-se a necessidade do desenvolvimento de um equipamento que pudesse representar, de modo mais aproximado, as condições verificadas no processo industrial de polimento de rochas ornamentais.

É sabido que a qualidade da superfície polida está em relação inversa com a rugosidade da mesma. Desta forma, é possível inferir, a partir das características superficiais da placa, a eficácia dos procedimentos adotados para polir o material pétreo.

\subsubsection{SIMULADOR DE POLIMENTO DE ROCHA - SPR}

O equipamento ora apresentado se baseia nos fundamentos do ensaio de abrasão pinon-disk, usado para medir o desgaste de ligas metálicas. Este ensaio consiste em submeter uma amostra de aço com formato de pino, pressionada sobre uma superfície áspera (lixa) que gira sobre um prato com movimento horizontal (Figura 4.130). O ensaio é definido pela Norma ASTM G 99-04, que considera basicamente as variáveis: carga aplicada (F), velocidade de rotação (W), raio da circunferência (r), área de contato (d) e a granulometria do abrasivo (D). A Figura 4.131 mostra um equipamento para ensaio pin-on-disk convencional utilizado na no Departamento de Material da Escola de Engenharia de São Carlos. 


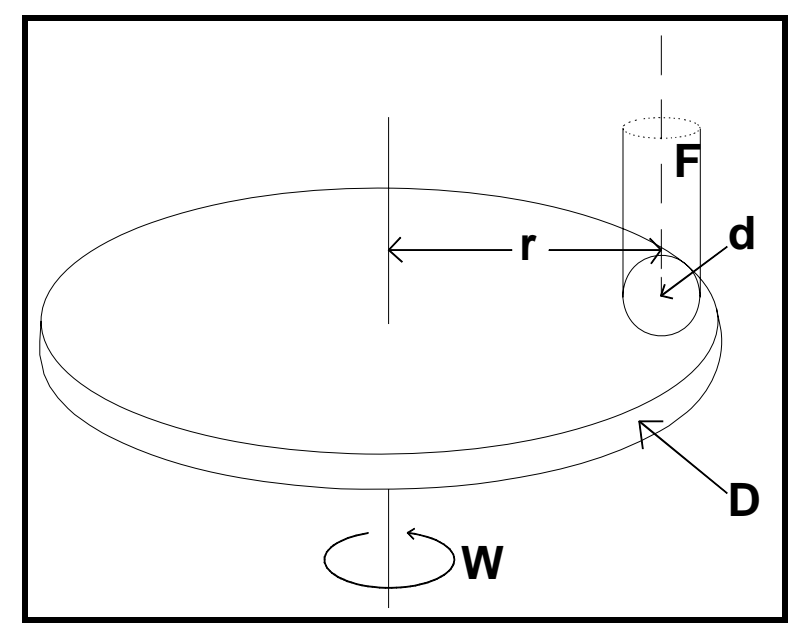

Figura 4.130 - Esquema do ensaio de abrasão com o equipamento pin-on-disk (ASTM, 2004).

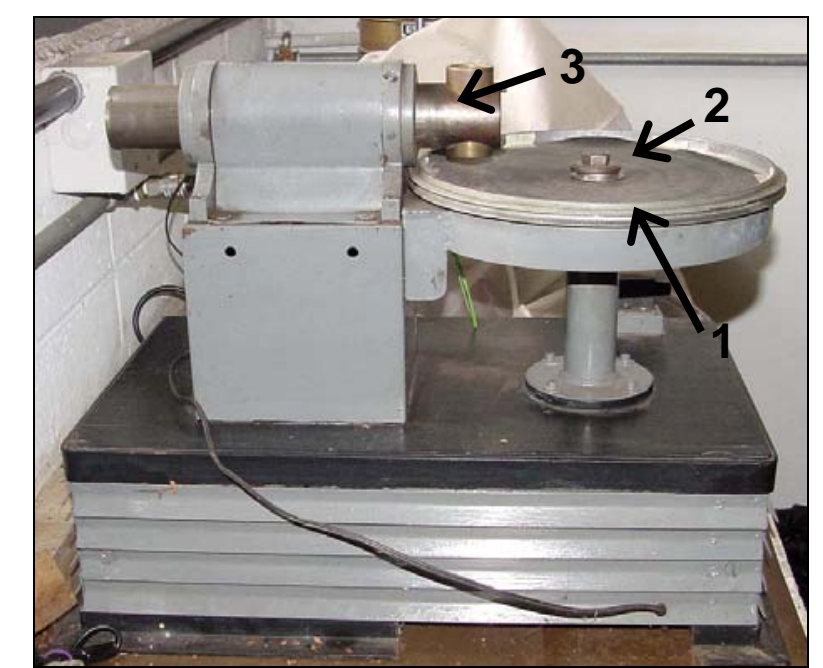

Figura 4.131 - Principais componentes do equipamento utilizado para a realização do ensaio de pin-ondisk tradicional: (1) Prato giratório; (2) Disposição da lixa abrasiva; (3) Compartimento para a colocação da amostra metálica a ser ensaiada.

Com base no desenvolvimento teórico e a concepção deste ensaio, foi construído um equipamento para o estudo do polimento de rochas, denominado SPR (Simulador de Polimento de Rocha). Enquanto que no ensaio pin-on-disk a amostra tem a forma de pino e é pressionada sobre a placa de abrasivo que gira horizontalmente, no SPR, ao contrário, o pino é o abrasivo que é pressionado sobre um disco de rocha que gira horizontalmente. Optou-se por essa inversão devido ao fato de que ao se ensaiar amostra de rocha com pequenas dimensões seria provável que não se conseguisse representar todos atributos importantes para 
uma boa compreensão do processo de desgaste que ocorre no polimento de rochas. Atributos como mineralogia, estrutura, textura não seriam devidamente considerados e caracterizados.

O equipamento em questão pode ser facilmente construído a partir de qualquer aparelho que possua um prato horizontal com velocidade variável e que suporte a aplicação de uma carga de até 2 bars. Para tanto, foi utilizada uma laminadora (politriz), comumente encontrado em laboratórios de petrografia (Figura 4.132), onde foram adaptados os seguintes dispositivos: (A) torre, (B) haste, onde são fixados os pesos e o copo e (C) pesos, para a aplicação de diferentes cargas no abrasivo (Figura 4.133). O Simulador de Polimento de Rocha (SPR) pode ser visto nas Figuras 4.134 e 4.135.

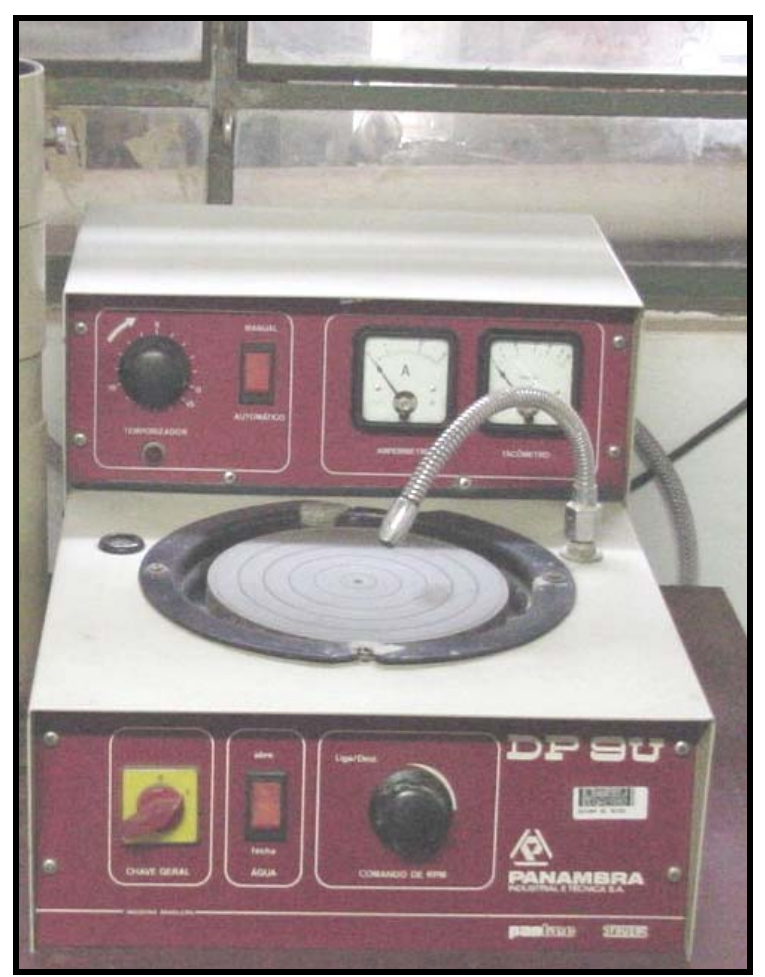

Figura 4.132 - Politriz para preparação de lâmina delgada para rochas utilizada como base para o desenvolvimento do Simulador de Polimento de Rocha (SPR). 


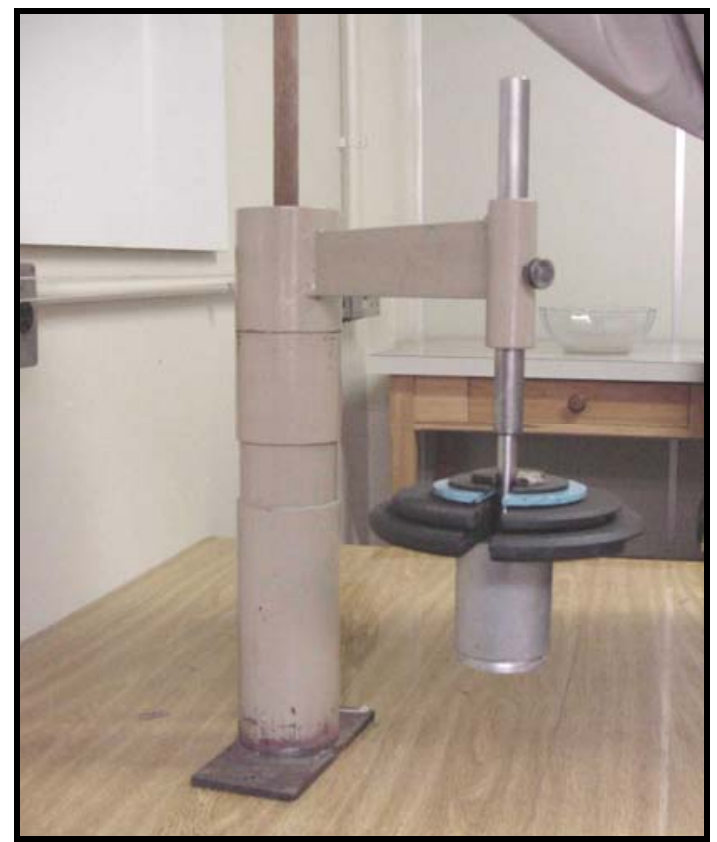

Figura 4.133 Conjunto de dispositivos acoplados a politriz para a montagem do Simulador de Polimento de Rocha (SPR).

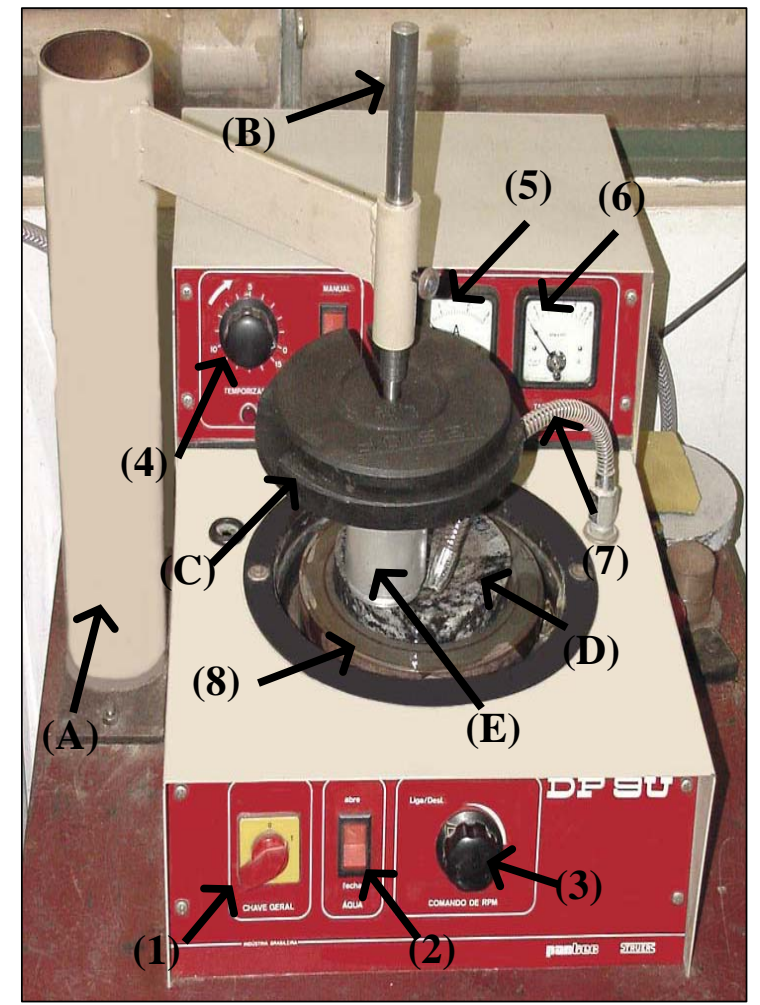

Figura 4.134 - Equipamento para ensaio de simulação de polimento em rocha (SPR): (1) Chave geral; (2) Dispositivo para saída de água; (3) Reostato; (4) Marcador de tempo; (5) Amperímetro; (6) Tacômetro; (7) Mangueira d’água; (8) Prato giratório. (A) Torre; (B) Haste; (C) Pesos; (D) Amostra de Rocha e (E) Dispositivo para colocação do abrasivo. 


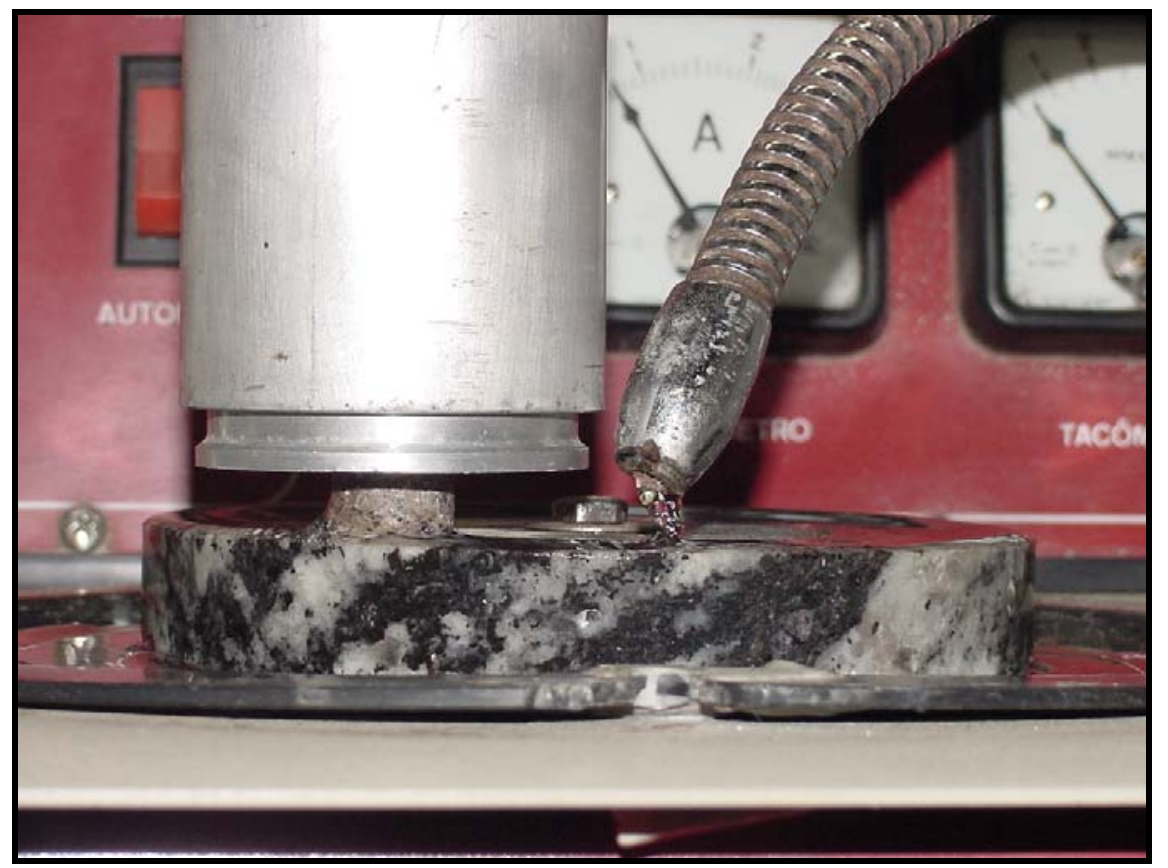

Figura 4.135 - Detalhe do ensaio de SPR. Notar a disposição do pino abrasivo e do disco de rocha.

\subsubsection{PERPARAÇÃO DOS CORPOS-DE-PROVA}

As amostras de rocha são conseguidas a partir da extração do disco de uma placa de rocha com coroa diamantada de diâmetro de $15 \mathrm{~cm}$ (Figura 4.136). Posteriormente realiza-se a retificação da geratriz do corpo-de-prova, com o objetivo de diminuir eventuais vibrações durante o ensaio, ocasionadas por excentricidade do furo central (Figura 4.137). A amostra é fixada ao prato por meio de um parafuso central.

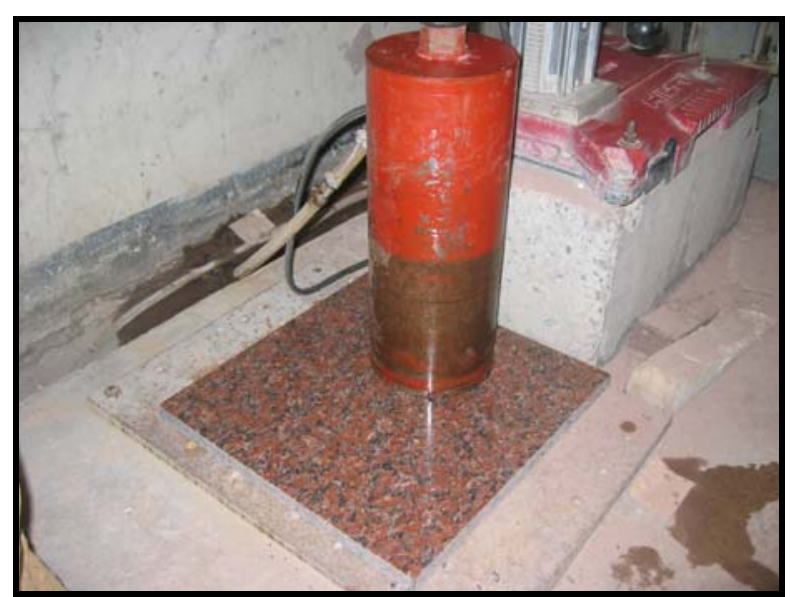

Figura 4.136 - Amostragem do corpo-de-prova de rocha utilizado no ensaio SPR. 


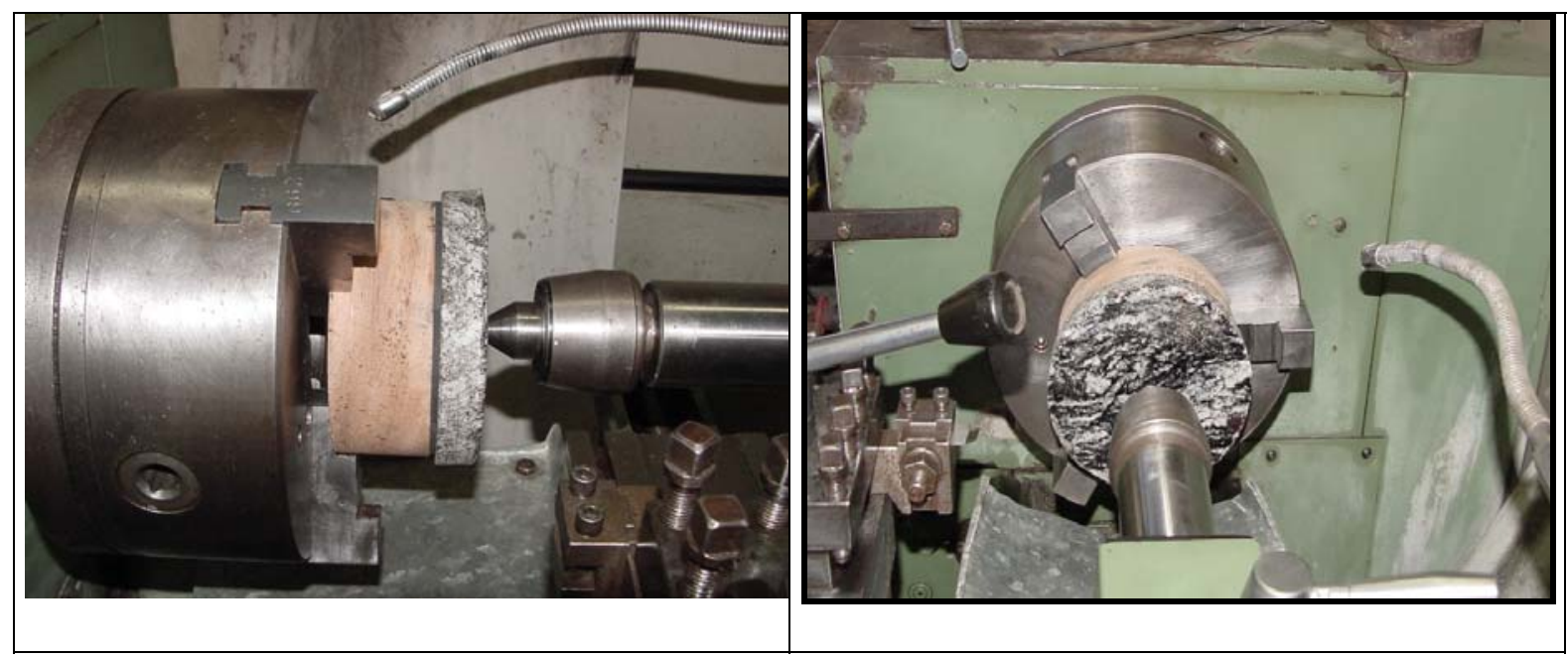

Figura 4.137 - Procedimento de retificação da geratriz do corpo-de-prova de rocha utilizado no ensaio SPR.

Os corpos-de-prova dos abrasivos (pino) foram conseguidos através de amostragem com perfuratriz a partir dos próprios rebolos abrasivos utilizados na indústria. Podem ser visualizados nas Figuras 4.138 e 4.139 .

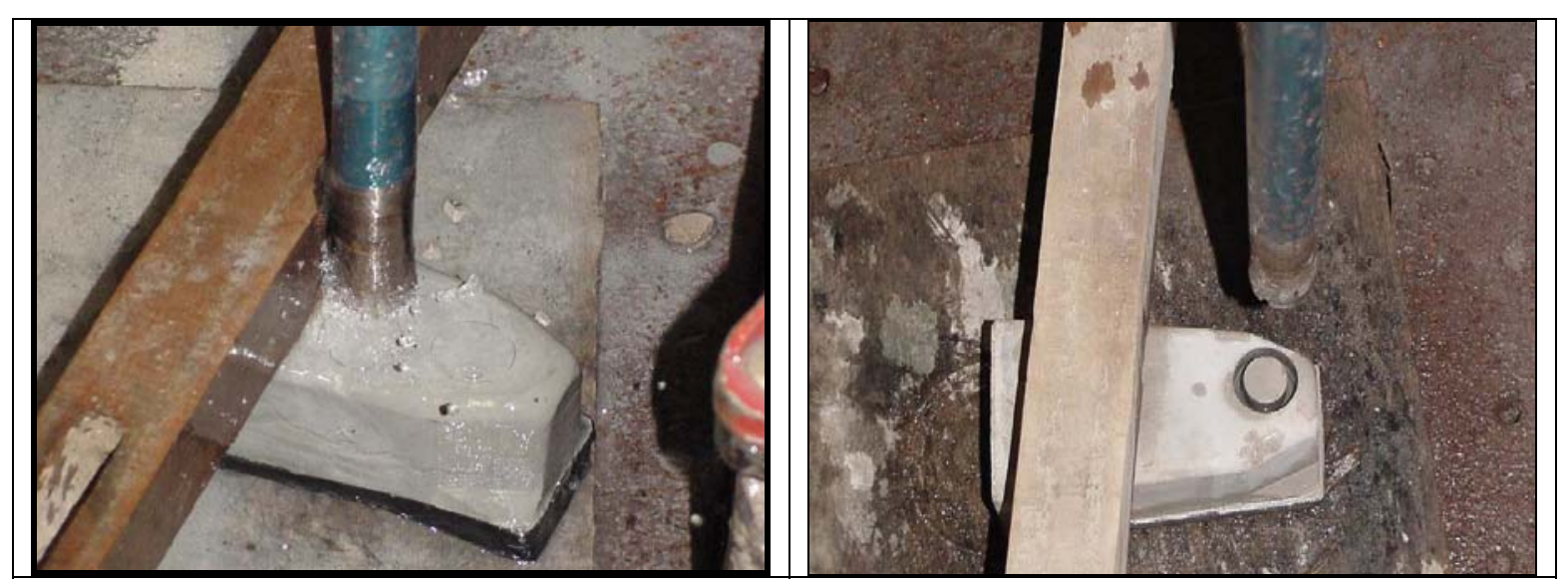

Figura 4.138 - Procedimentos de amostragem do corpo-de-prova de abrasivo utilizado no ensaio SPR.

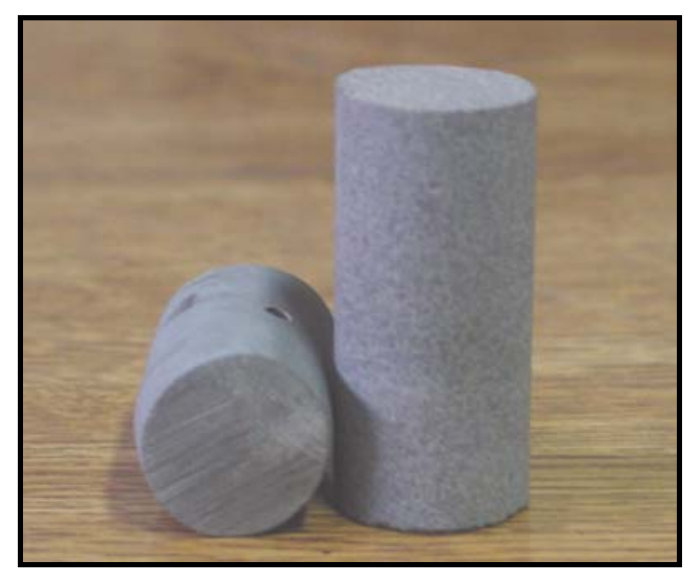

Figura 4.139 - Amostra retirada do rebolo abrasivo para o ensaio SPR (diâmetro = 2 cm). 


\subsubsection{PROCEDIMENTOS DO ENSAIO}

O objetivo deste ensaio é verificar quais situações, em relação à carga, tempo e velocidade, são as mais indicadas para se obter a melhor qualidade no polimento de um determinado tipo litológico. Foram ensaiadas as mesmas rochas descritas anteriormente, ou seja, o gnaisse Preto indiano e o sienogranito Vermelho Brasília, o monzogranito Cinza Castelo, o migmatito Desert Storm, o charnoquito Verde Labrador e o sienogranito Vermelho Capão Bonito. As variáveis operacionais do ensaio são: velocidade de rotação e carga aplicada. Foram estabelecidas três velocidades (200 rpm, $400 \mathrm{rpm}$ e $600 \mathrm{rpm})$; duas cargas aplicadas ( 1 bar e 2 bars) tomando-se como ponto de partida as velocidades e cargas utilizadas em politrizes, sendo também estabelecidas três tempos ( 2 min, 4 min e 6 min). Estipulou-se em dezoito o número de corpos-de-prova necessários para cumprir as possibilidades de combinação entre as variáveis consideradas. A Figura 4.140 exemplifica o registro o caminhamento do abrasivo sobre o disco de rocha. A Figura 4.141 mostra um corpo-de-prova utilizado no ensaio SPR, sendo é possível visualizar a faixa de atrito, faixa esta que representa a região de contato entre o abrasivo e a rocha.

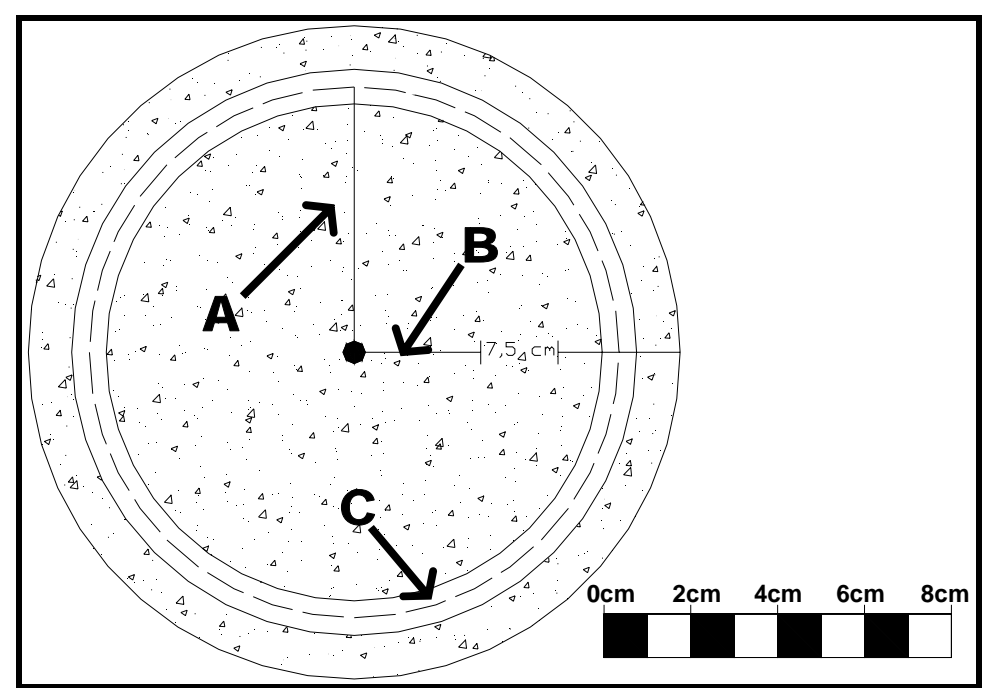

Figura 4.140 - Esquema do corpo-de-prova de rocha utilizado no ensaio SPR: (A) Raio para determinação do perímetro de ensaio; (B) Raio do corpo-de-prova e (C) Faixa de atrito. 


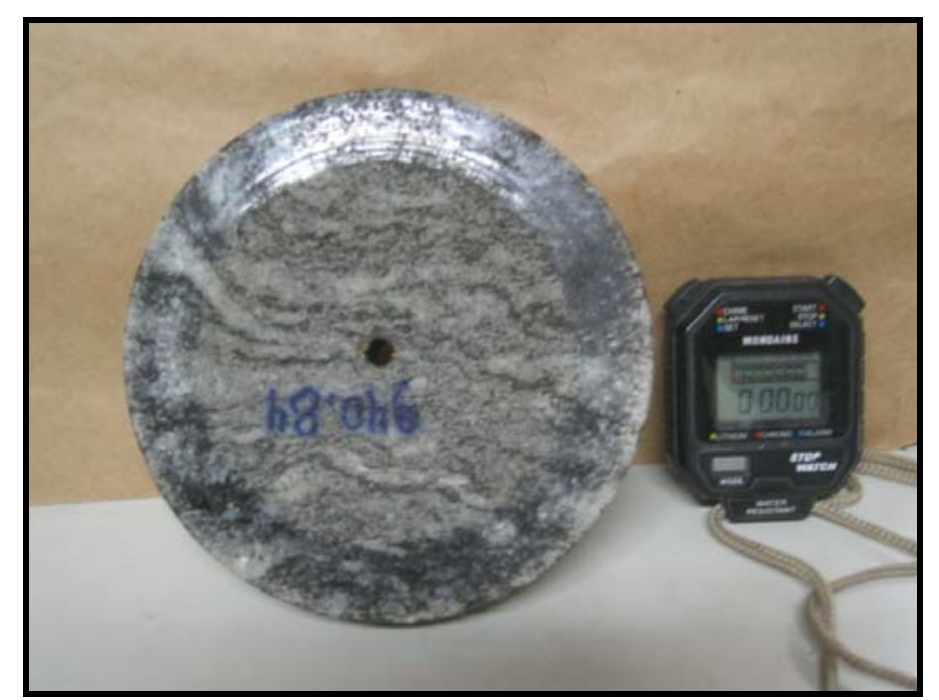

Figura 4.141 - Corpo-de-prova submetido ao ensaio SPR.

O ensaio inicia-se com a fixação da amostra de rocha sobre o prato giratório, por meio de um parafuso central e a colocação dos pesos sobre o pino abrasivo, sendo, em seguida, aberta a torneira de água e ligado motor, dando-se o início do movimento circular. O primeiro corpo-de-prova é submetido a um carregamento de 1 bar, velocidade de $200 \mathrm{rpm}$ e tempo de 2 minutos. As amostras subseqüentes são submetidas a valores cada vez maiores de uma variável de cada vez, ao ponto que, no último corpo-de-prova as condições de ensaio serão de $600 \mathrm{rpm}, 2$ bar e 6 minutos. A Tabela 4.7 mostra a nomenclatura adotada para as seis rochas estudadas, bem como as condições de ensaio das 18 amostras por rocha, totalizando 108 corpos-de-prova. Considerando os 108 corpos-de-prova sendo submetidos às 10 etapas de beneficiamento (24 mesh, 36 mesh, 60 mesh, 120 mesh, 220 mesh, 400 mesh, 600 mesh, 800 mesh, 1200 mesh, e Lustro), a presente pesquisa realizou 1080 ensaios no SPR, o que permite dar uma boa margem de segurança aos resultados obtidos. Todas as amostras escolhidas para a realização deste ensaio passaram por uma análise táctil-visual com o objetivo de verificar a existência ou não de caneluras ou outras feições, geradas por uma serragem baixa qualidade. Tomou-se tal cuidado para não haver surpresas com valores excessivos de perda de massa de rocha e abrasivo nas fazes de desbaste (24 mesh, 36 mesh e 60 mesh). 
TABELA 4.7 - Nomenclatura das amostras utilizadas no Simulador de Polimento de Rocha (SPR).

\begin{tabular}{|c|c|c|c|c|c|c|c|c|}
\hline \multicolumn{6}{|c|}{ AMOSTRAS } & $\begin{array}{l}\text { TEMPO } \\
\text { (min.) }\end{array}$ & $\begin{array}{c}\text { CARGA } \\
\text { (bar) }\end{array}$ & $\begin{array}{c}\text { VELOCIDADE } \\
\text { (rpm) }\end{array}$ \\
\hline PI1A & VB1A & CC1A & DS1A & VL1A & CB1A & 2 & 1 & 200 \\
\hline PI1B & VB1B & CC1B & DS1B & VL1B & CB1B & 2 & 1 & 400 \\
\hline PI1C & VB1C & CC1C & DS1C & VL1C & CB1C & 2 & 1 & 600 \\
\hline PI2A & VB2A & CC2A & DS2A & VL2A & CB2A & 4 & 1 & 200 \\
\hline PI2B & VB2B & CC2B & DS2B & VL2B & CB2B & 4 & 1 & 400 \\
\hline PI2C & VB2C & CC2C & DS2C & VL2C & CB2C & 4 & 1 & 600 \\
\hline PI3A & VB3A & CC3A & DS3A & VL3A & CB3A & 6 & 1 & 200 \\
\hline PI3B & VB3B & ССЗВ & DS3B & VL3B & CB3B & 6 & 1 & 400 \\
\hline PI3C & VB3C & ССЗС & DS3C & VL3C & CB3C & 6 & 1 & 600 \\
\hline PI4A & VB4A & CC4A & DS4A & VL4A & CB4A & 2 & 2 & 200 \\
\hline PI4B & VB4B & CC4B & DS4B & VL4B & CB4B & 2 & 2 & 400 \\
\hline PI4C & VB4C & CC4C & DS4C & VL4C & CB4C & 2 & 2 & 600 \\
\hline PI5A & VB5A & CC5A & DS5A & VL5A & CB5A & 4 & 2 & 200 \\
\hline PI5B & VB5B & CC5B & DS5B & VL5B & CB5B & 4 & 2 & 400 \\
\hline PI5C & VB5C & CC5C & DS5C & VL5C & CB5C & 4 & 2 & 600 \\
\hline PI6A & VB6A & CC6A & DS6A & VL6A & CB6A & 6 & 2 & 200 \\
\hline PI6B & VB6B & CC6B & DS6B & VL6B & CB6B & 6 & 2 & 400 \\
\hline PI6C & VB6C & CC6C & DS6C & VL6C & CB6C & 6 & 2 & 600 \\
\hline
\end{tabular}

Legenda: PI - Preto Indiano; VB - Vermelho Brasília; CC - Cinza Castelo; DS - Desert Storm; VL - Verde Labrador; VB - Vermelho Capão Bonito. 
Em cada corpo-de-prova ensaiado foram anotadas as respectivas massas, antes e depois do ensaio, bem como a massa consumida de abrasivo e a amperagem no instante do ensaio (Figura 4.142). A comparação da qualidade das superfícies finais de cada corpo-deprova (lustro) foi realizado de modo indireto, com o auxílio de um glossmeter, através da medição dos brilhos das faixas de atrito de cada corpo-de-prova.

\begin{tabular}{|c|c|c|c|c|c|}
\hline \multicolumn{2}{|l|}{ NOMEDAROOHA: } & \multicolumn{2}{|l|}{ - ABRASIVON- } & & \\
\hline \multicolumn{2}{|l|}{$\mathrm{PI} 1 \mathrm{~A}$} & \multicolumn{2}{|l|}{$\mathrm{P} \mid 1 \mathrm{~B}$} & \multicolumn{2}{|l|}{$\mathrm{PI} 1 \mathrm{C}$} \\
\hline TEMPO(S) & 2 & TEVPO(S) & 2 & TEMPO(S) & 2 \\
\hline CARGA(BAR) & 1 & CARGA(BAR) & 1 & CARGA(BAR) & 1 \\
\hline VEOCDADE(MS) & 200 & VEOCDADE(MS) & 400 & VEOCDADE(MS) & 600 \\
\hline \multicolumn{6}{|c|}{ PARÁNEIROSDOENSAIO } \\
\hline PERDADEROCHA(g) & & PERDADEROCHA(g) & & PERDADEROCHA(g) & \\
\hline PERDADEABRASIVO (g) & & PERDADEABRASIVO (g) & & PERDADEABRASIVO (g) & \\
\hline AMPERAGEM(A) & & AMPERAGEM(A) & & AMPERAGEM(A) & \\
\hline
\end{tabular}

Figura 4.142 - Modelo de planilha utilizado no SPR. 


\subsection{TRATAMENTO DOS DADOS NO EQUIPAMENTO SPR}

A partir das amostras submetidas ao ensaio SPR duas formas de aquisição de dados foram realizadas:

- Determinação das perdas de massa de rocha e abrasivos por etapa de desgaste e medição da amperagem do motor de cada etapa. A pesagem da perda de material rochoso foi só possível até a quarta etapa de desgaste (\# 120 mesh) devido ao fato que, a partir desta etapa, a perda de material foi muito pequena e de difícil medição. Em cada ensaio, tanto a amostra de rocha como o abrasivo foram levados à estufa, a uma temperatura de 60 graus, durante 30 minutos. Após a medição de material perdido, as amostras voltavam para o SPR para a realização de uma nova etapa de desgaste.

- Análise qualitativa, com auxílio de um imageador, das superfícies geradas. Os perfis de rugosidade foram obtidos com o auxílio do mesmo rugosímetro utilizado para a caracterização da rugosidade das amostras dos materiais provenientes da empresa Granita Ltda. (Capítulo 3). As propriedades do imageador utilizado na pesquisa serão detalhadas mais à frente.

Neste Capítulo serão mostrados os gráficos, gerados no programa Statistica 5.0, das relações de perdas e variação da amperagem em função dos corpos-de-prova utilizados nos ensaios SPR.

\subsubsection{RELAÇÕES DE PERDA DE MASSA DE ROCHA E DE ABRASIVO}

As figuras a seguir mostram os valores de desgaste das seis rochas utilizadas na pesquisa nas quatro primeiras fases de desgaste (Figuras 4.143, 4.144, 4.145 e 4.146). 


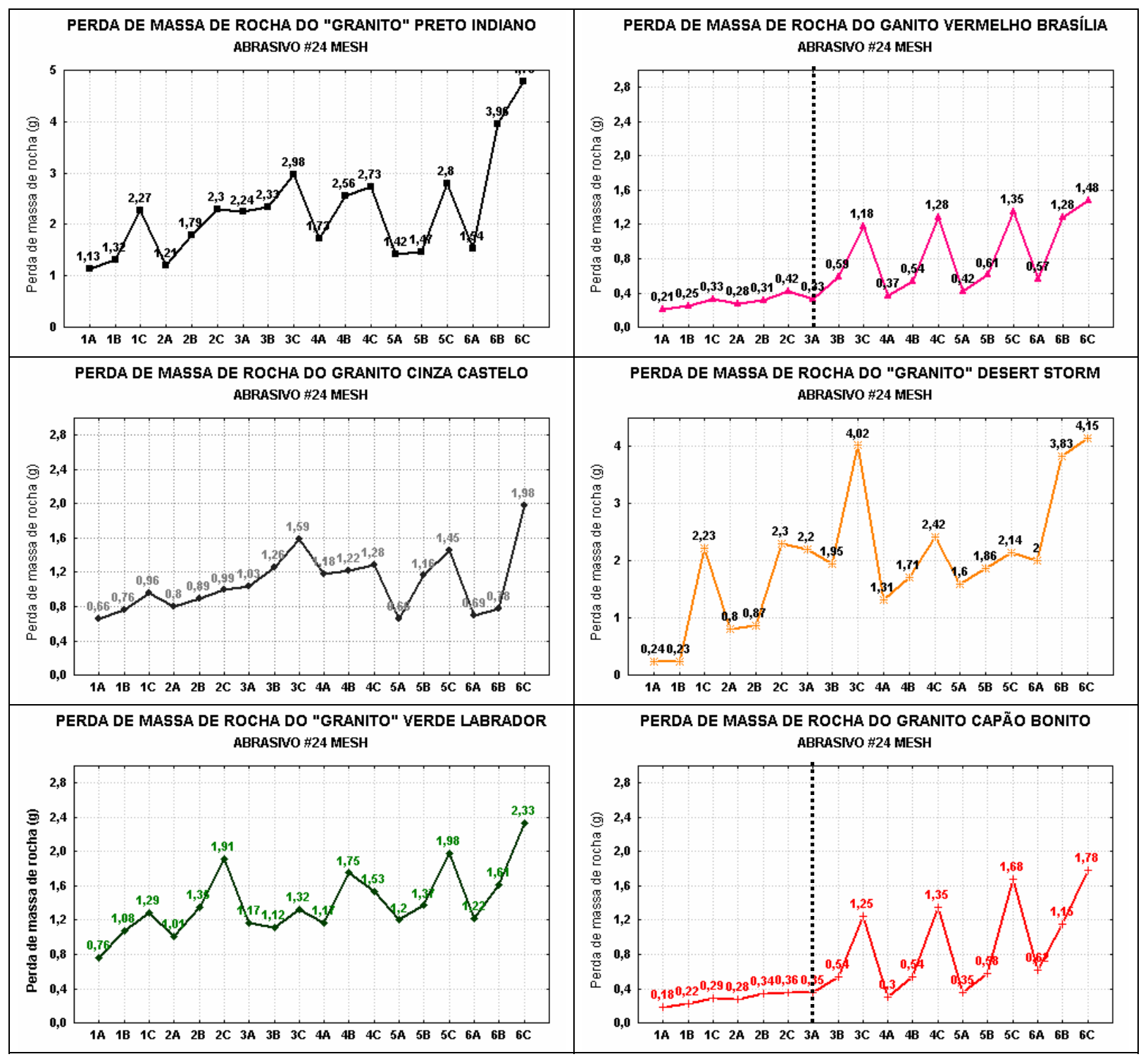

Figura 4.143 - Valores de perda de massa de rocha das seis rochas estudadas na primeira fase de desgaste (24 mesh). 


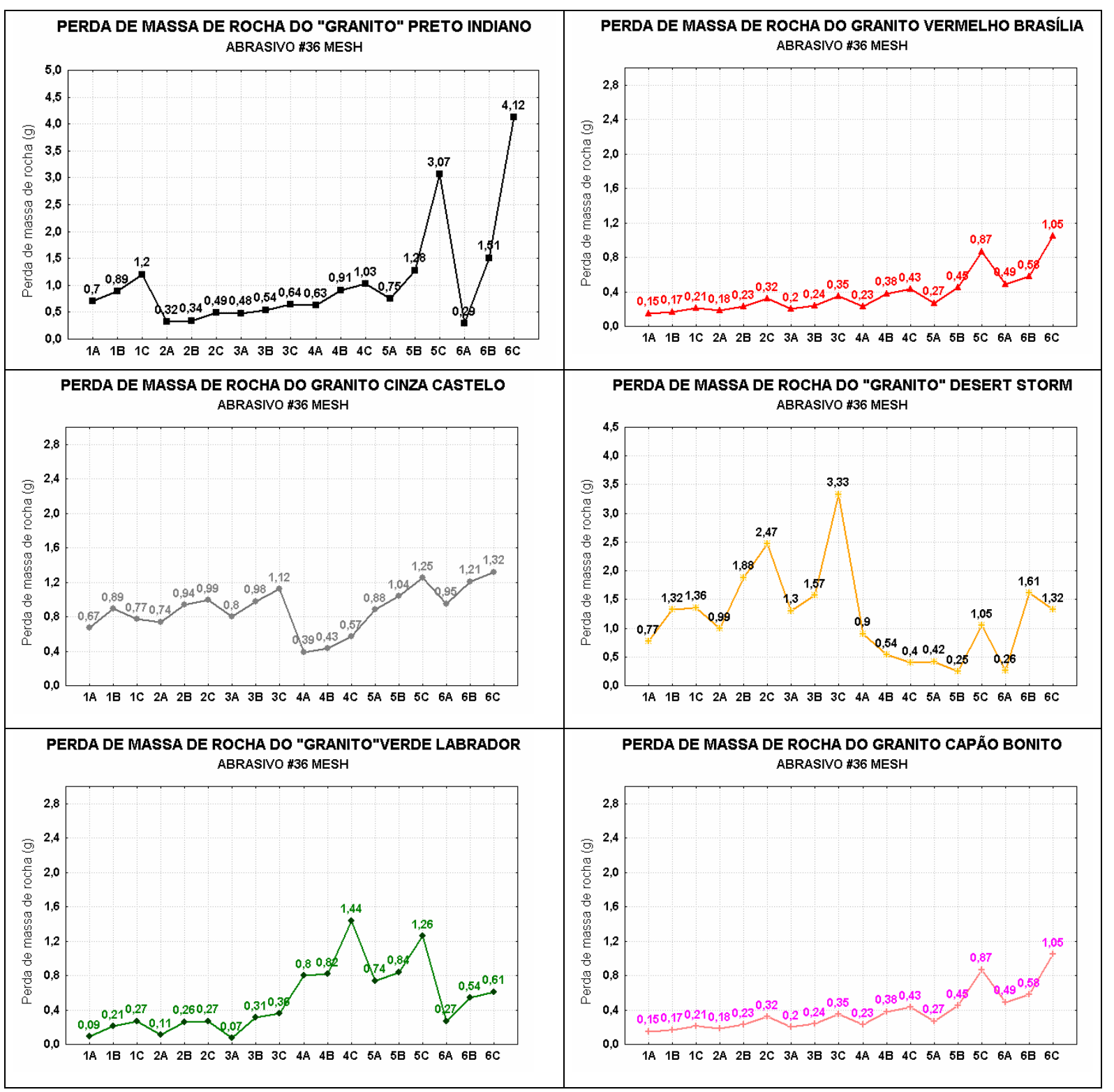

Figura 4.144 - Valores de perda de massa de rocha das seis rochas estudadas na segunda fase de desgaste (36 mesh). 


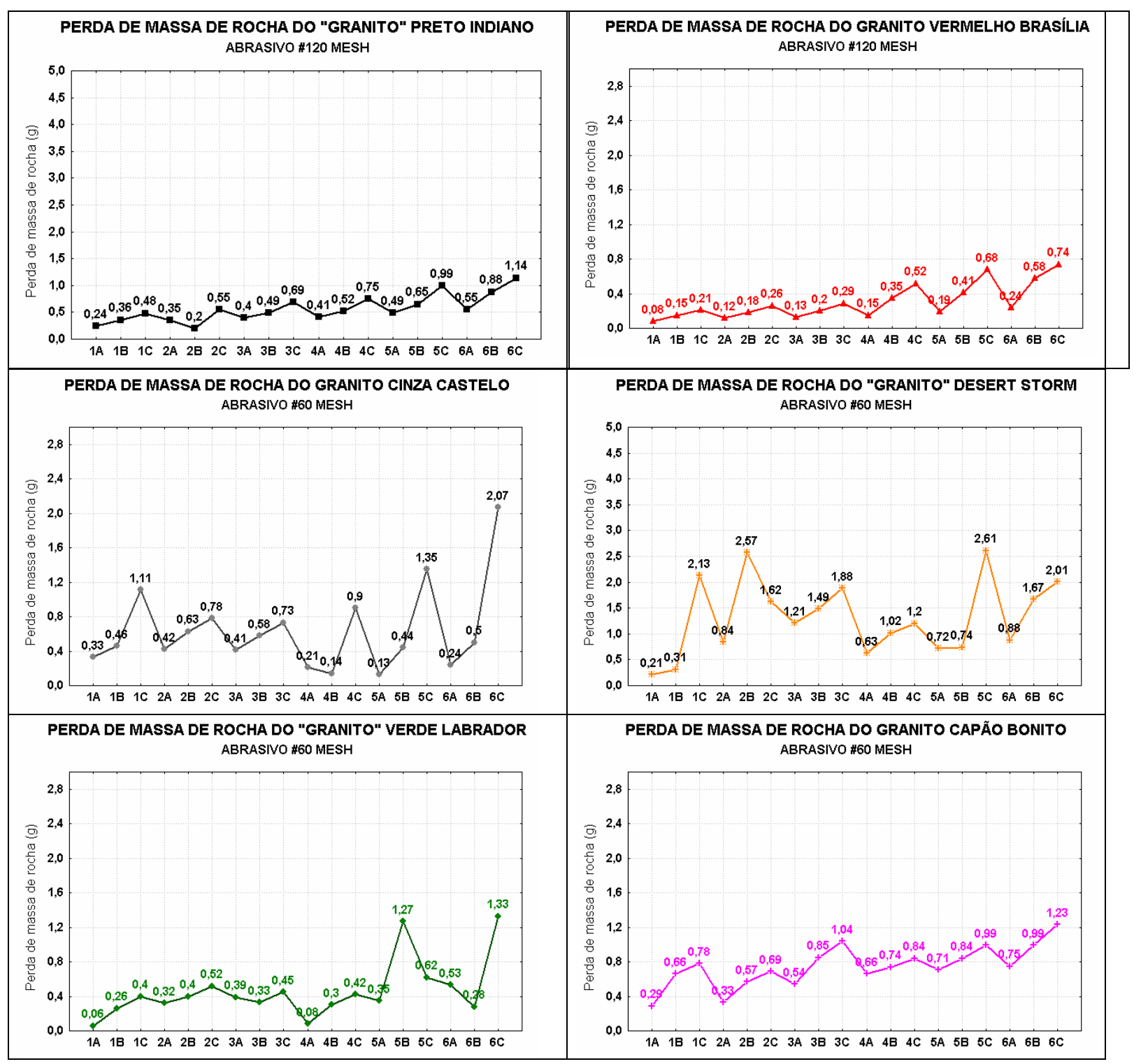

Figura 4.145 - Valores de perda de massa de rocha das seis rochas estudadas na terceira fase de desgaste (60 mesh). 


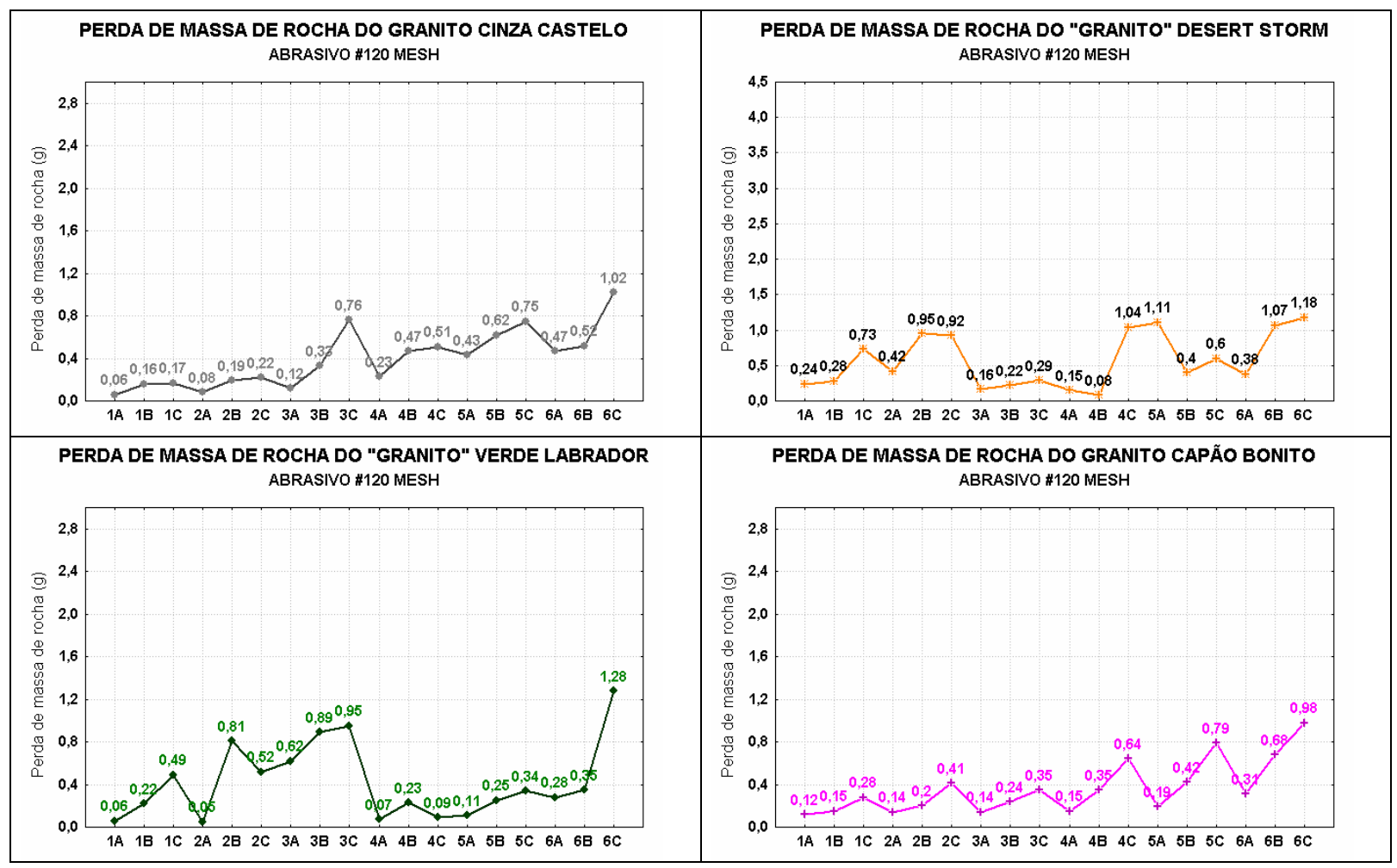

Figura 4.146 - Valores de perda de massa de rocha das seis rochas estudadas na quarta fase de desgaste (120 mesh).

Diante dos padrões de desgaste que as seis rochas apresentaram nas quatro primeiras fases de abrasão é possível constatar que:

A) A escolha de duas rochas de composição mineralógica e características estruturais muito próximas tinha como objetivo testar a repetitibilidade dos resultados obtidos, com vista a assegurar a confiabilidade dos dados. Os granitos Vermelho Brasília e Capão Bonito apresentaram resultados muito próximos ao longo das etapas de desgaste, o que mostra que os procedimentos adotados para a realização dos ensaios foram bem sucedidos.

B) As duas rochas que apresentam uma maior anisotropia (Preto Indiano e Desert Storm) foram as que mostraram maiores valores de desgaste, indicando que pode existir uma 
contribuição da alternância de bandas, com resistências diferentes, na taxa de desgaste da rocha.

C) Para as duas primeiras etapas de desgaste (\#24 e \#36), onde as rochas ainda apresentam uma rugosidade alta devido a etapa de serragem do bloco e, por conseqüência, a retirada de material é mais intensa, o tempo de exposição da amostra ao abrasivo é um fator relevante. Outro aspecto que deve ser considerado é que os riscos deixados pelos abrasivos mais grosseiros (\#24 e \#36) marcam a rochas com ranhuras mais proeminentes e, a medida em que se processa o polimento, tais sulcos vão diminuindo de porte, o que reflete também numa diminuição na perda de material por desgaste abrasivo.

Para de ter uma visão integrada dos resultados obtidos, optou-se em elaborar gráficos de superfície, que permitem uma análise simultânea da perda de massa de rocha dos 18 corpos-de-prova nas quatro fases de desgaste.

Os gráficos de superfície mostram que para o Preto Indiano (Figura 4.147) as maiores taxas de desgaste da rocha se concentram nos dois primeiros abrasivos principalmente nas situações mais severas de desgaste.

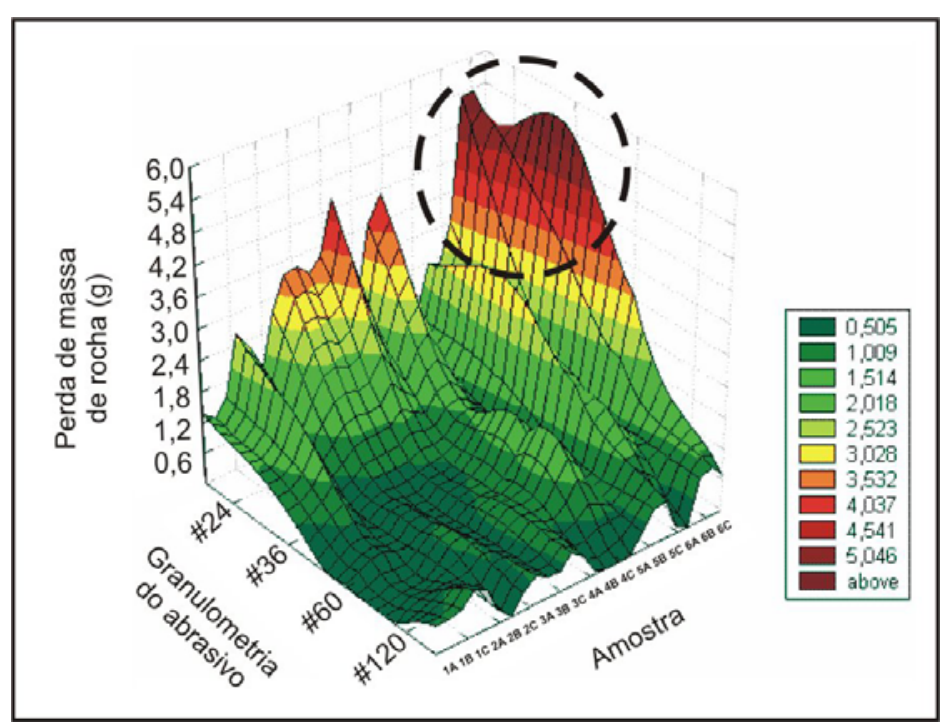

Figura 4.147 - Gráficos de superfície mostrando a intensidade do desgaste do "granito” Preto Indiano ao longo de diferentes condições de desgaste com os abrasivos de granulometrias 24, 36, 60 e 120 mesh. 
No granito Vermelho Brasília ocorre situações específicas onde a susceptibilidade ao desgaste é maior, o que indica que as condições operacionais influem de maneira diferenciada nesse tipo de rocha. $\mathrm{O}$ abrasivo \#36 mesh começou a ter real influência no desgaste da rocha a partir da $13^{\mathrm{a}}$ condição operacional de desgaste $(5 \mathrm{~A})$, mostrando que para condições menos severas esse abrasivo pode ser substituído diretamente pelo seguinte (\#60 mesh) (Figura 4.148).

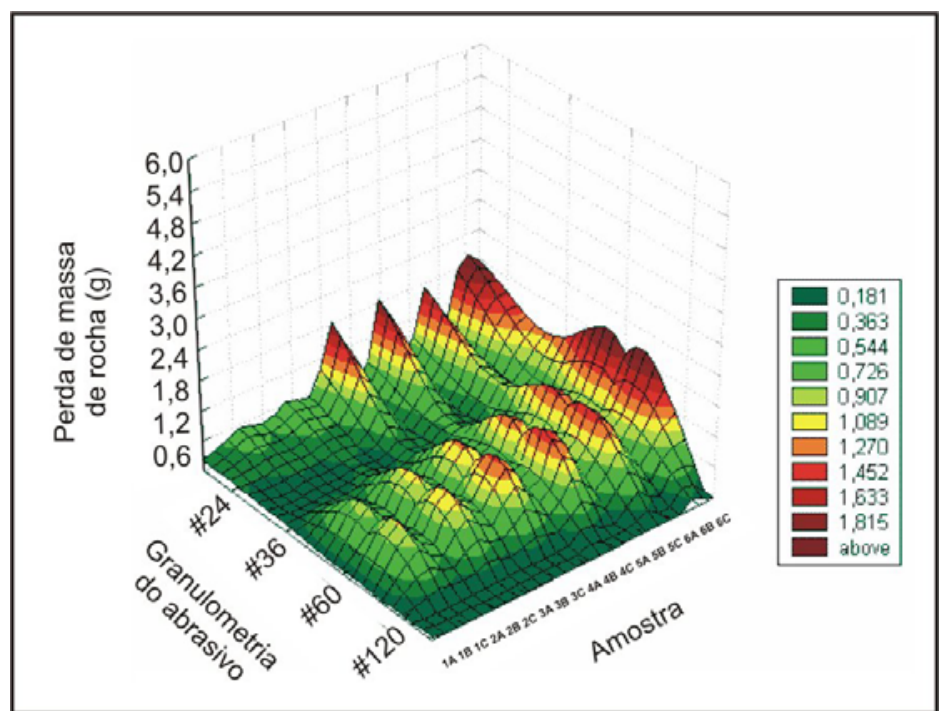

Figura 4.148 - Gráficos de superfície mostrando a intensidade do desgaste do granito Vermelho Brasília ao longo das diferentes condições de desgaste com os abrasivos de granulometrias 24, 36, 60 e 120 mesh.

No granito Cinza Castelo novamente se repete a pequena influência que tem o abrasivo \#36 mesh como responsável pela abrasão da rocha. É possível notar que nos últimos estágios de desgaste, a condições mais severas, a taxa de remoção de material rochoso no abrasivo citado fica muito aquém dos valores obtidos nos outros três abrasivos (Figura 4.149). 


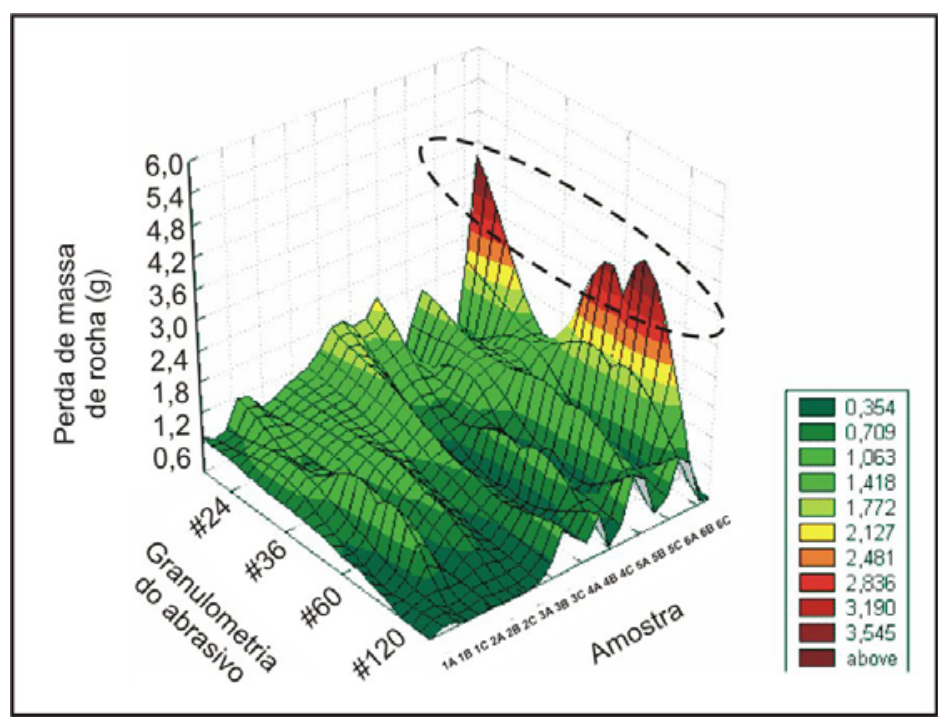

Figura 4.149 - Gráficos de superfície mostrando a intensidade do desgaste do granito Cinza Castelo ao longo das diferentes condições de desgaste com os abrasivos de granulometrias 24, 36, 60 e 120 mesh. Notar a depressão verificada nas taxas de remoção do abrasivo 36 mesh.

Similarmente ao ocorrido com a primeira rocha estudada (Preto Indiano), a taxa de remoção de material rochoso encontrada no "granito" Desert Storm foi consideravelmente alta, principalmente no primeiro abrasivo e nas condições mais severas (Figura 4.150). Em tais condições, o abrasivo \#36 mesh novamente apresentou uma pequena taxa de remoção de rocha. Cabe lembrar que esta rocha apresentou uma variedade composicional grande, o que pode falsear tais resultados.

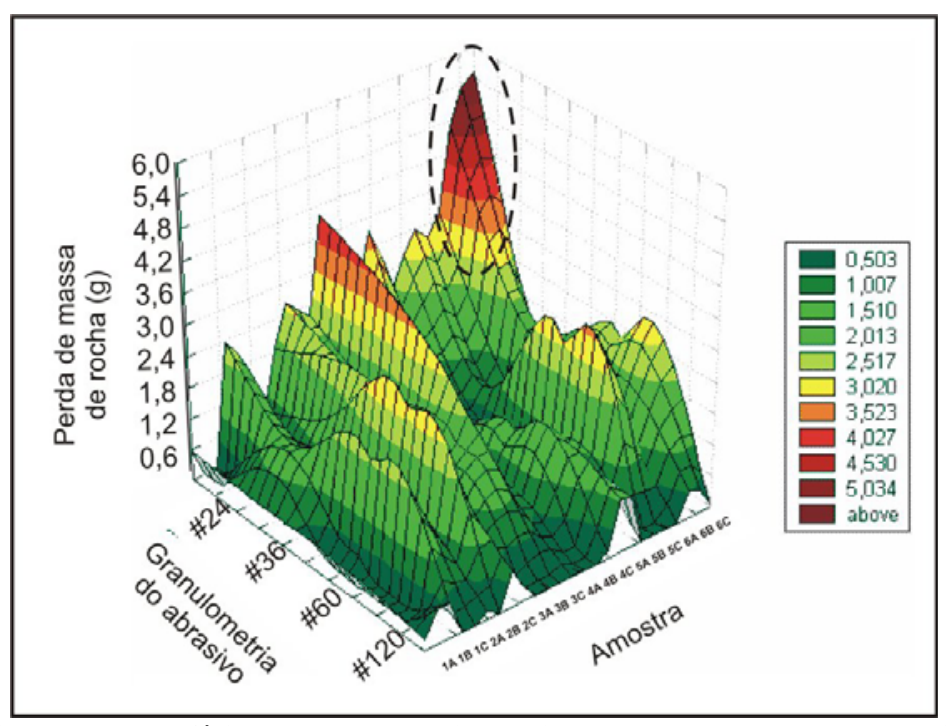

Figura 4.150 - Gráficos de superfície mostrando a intensidade do desgaste do "granito” Desert Storm ao longo das diferentes condições de desgaste com os abrasivos de granulometrias 24, 36, 60 e 120 mesh. 
Para o "granito" Verde Labrador é verificado também a pequena contribuição do abrasivo \#36 mesh na taxa de remoção de material rochoso. Ocorre um pico acentuado neste material quando submetido às condições mais severas e no primeiro abrasivo (Figura 4.151).

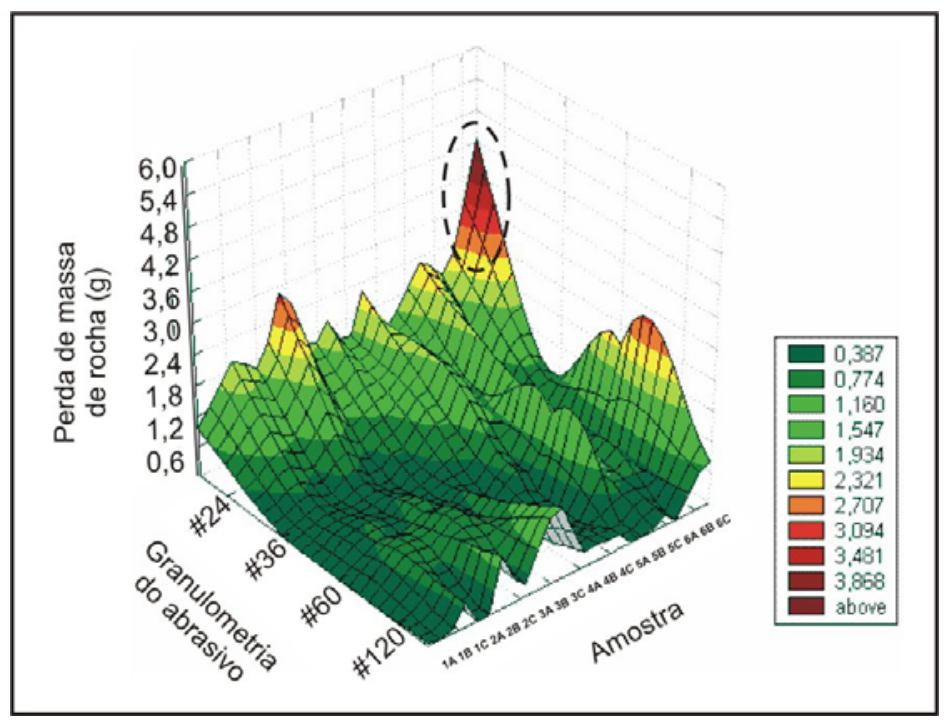

Figura 4.151 - Gráficos de superfície mostrando a intensidade do desgaste do "granito" Verde Labrador ao longo das diferentes condições de desgaste com os abrasivos de granulometrias 24, 36, 60 e 120 mesh.

É possível notar que o padrão do gráfico de superfície encontrado para o granito Vermelho Capão Bonito em muito se assemelha ao gráfico de superfície do granito Vermelho Brasília, o que além de corroborar a tese de que os resultados do ensaio SPR são confiáveis, mostra também que cada tipo litológico irá responder a uma solicitação de desgaste de acordo com suas propriedades físicas e petrográficas (Figura 4.152). 


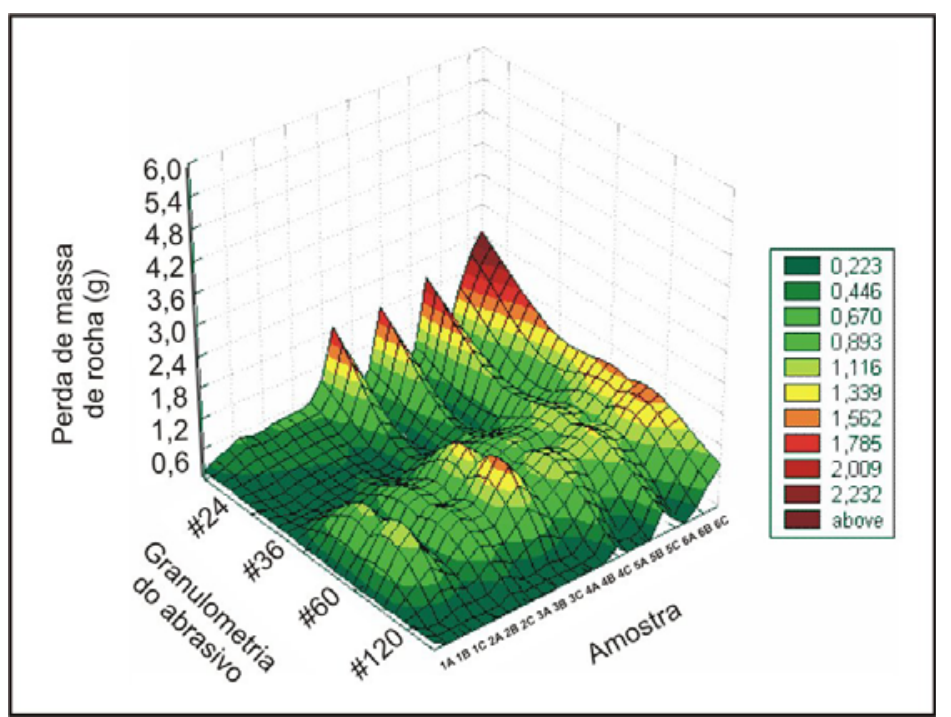

Figura 4.152 - Gráficos de superfície mostrando a intensidade do desgaste do granito Vermelho Capão Bonito ao longo das diferentes condições de desgaste com os abrasivos de granulometrias 24, 36, 60 e 120 mesh.

Em relação ao consumo de abrasivo nas quatro primeiras etapas, o "granito" Preto Indiano foi o que mais causou a perda de massa de abrasivo. Vale lembrar que esta rocha foi a que apresentou as maiores taxa de perda de massa de rocha também. Em suma, a rocha com intercalação de bandas composicionais também consumiu mais abrasivo em relação às outras rochas estudadas com durezas maiores (Figura 4.153). Tal fato mostra que a estrutura da rocha em muito influencia o sistema tribológico. Possivelmente esses altos valores de perda de massa de abrasivo se devem ao fato da intercalação entre os níveis quartzo-feldspáticos e micáceos. Os níveis micáceos, menos resistentes, sofrem um rebaixamento em relação aos níveis granulares quando submetidos à carga feita pelo rebolo abrasivo. Tal rebaixamento causa um ressalto nestes últimos, o que pode gerar a perda de abrasivo, não só por abrasão, mas também por um choque mecânico do abrasivo nesses ressaltos (fadiga).

Para a análise do consumo de abrasivo considerando as quatro etapas de desgaste juntamente com as dezoito condições operacionais, optou-se pela execução de gráficos em linha, pois facilitaria a visualização das perdas de abrasivo nestas quatro etapas. 


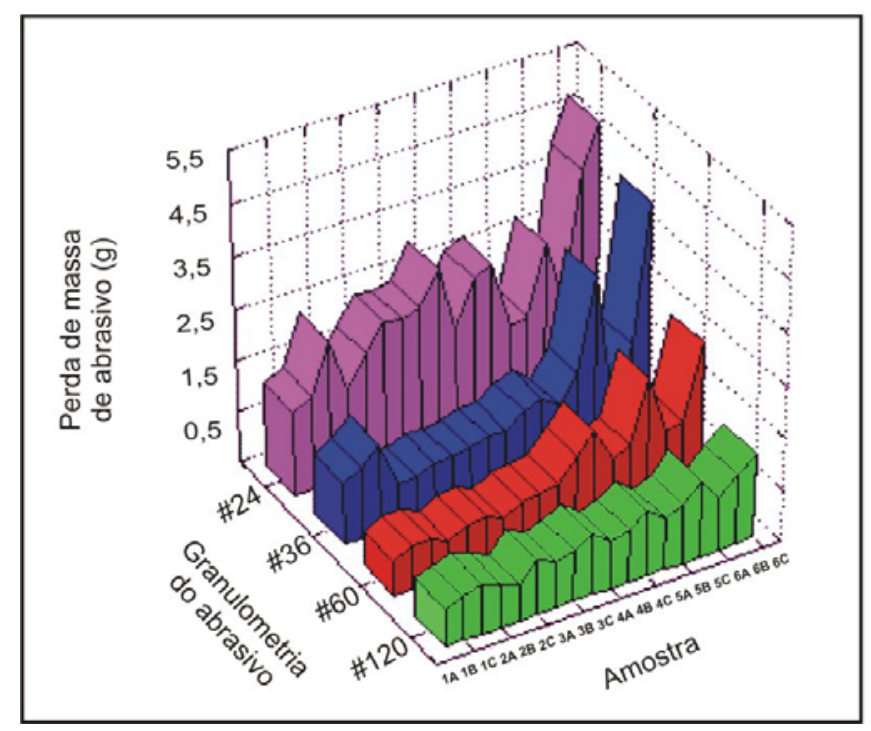

Figura 4.153 - Gráfico em linha mostrando taxas de desgaste dos abrasivos no "granito" Preto Indiano ao longo das etapas de desgaste com as granulometrias de abrasivo 24, 36, 60 e 120 mesh.

Para o granito Vermelho Brasília a quantidade de abrasivo desgastado nas quatro etapas ficou muito abaixo dos valores encontrados para o Preto Indiano (Figura 4.154). Devido ao fato desta rocha apresentar baixo grau de anisotropia, o processo de desgaste foi meramente o abrasivo, não tendo contribuição de um desgaste por fadiga. Percebe-se que as relações entre abrasivo e rocha transcendem os valores de dureza de cada componente, tornando o grau de anisotropia da rocha uma variável importante no processo de desgaste.

Tanto nesta rocha como nas demais estudadas o abrasivo \#36 mesh foi o que menos se desgastou. Este abrasivo também em pouco contribuiu para o desgaste do material rochoso, sendo o abrasivo de menor importância nas quatro primeiras etapas de polimento. 


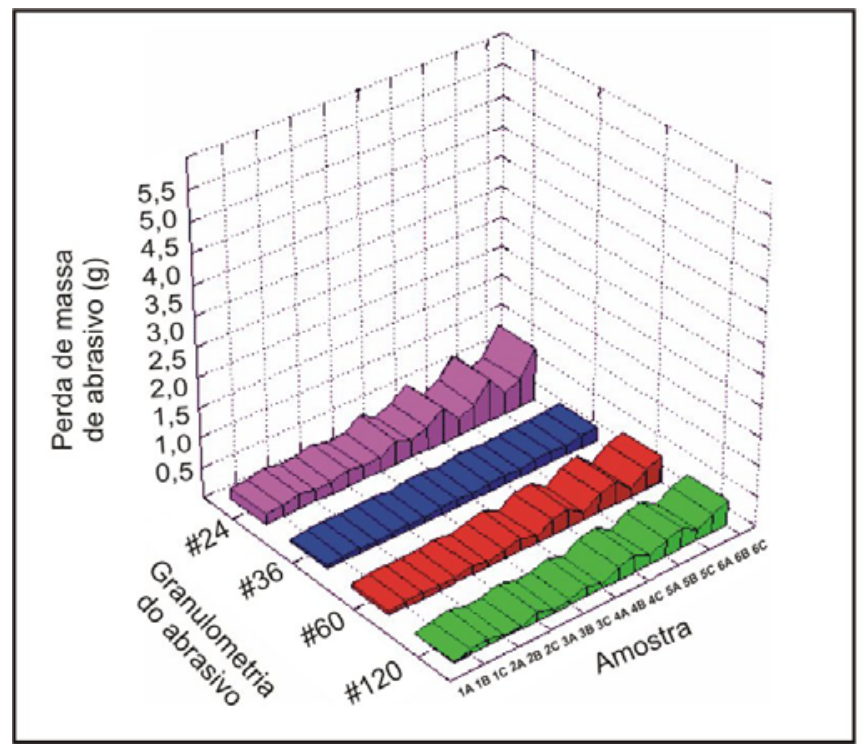

Figura 4.154 - Gráfico em linha mostrando taxas de desgaste dos abrasivos no granito Vermelho Brasília ao longo das etapas de desgaste com as granulometrias de abrasivo 24, 36, 60 e 120 mesh.

Os valores das taxas de perda de abrasivo para os corpos-de-prova do granito Cinza Castelo apresentaram-se maiores principalmente nas etapas \#60 e \#120 mesh. As situações operacionais mais severas foram as que causaram o maior consumo desses abrasivos (Figura 4.155).

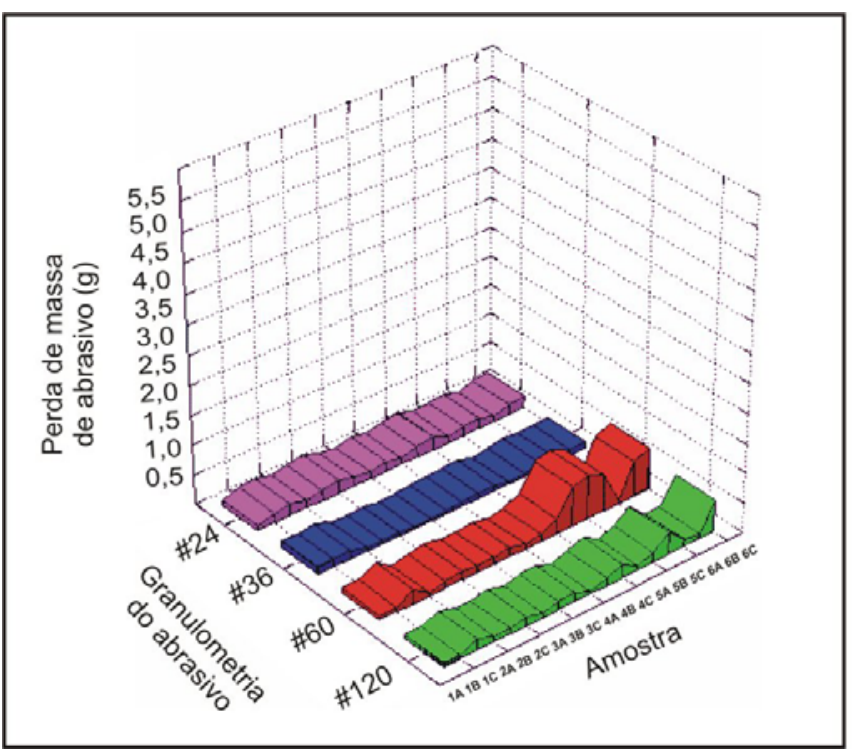

Figura 4.155 - Gráfico em linha mostrando taxas de desgaste dos abrasivos no granito Cinza Castelo ao longo das etapas de desgaste com as granulometrias de abrasivo 24, 36, 60 e 120 mesh. 
Devido à alta heterogeneidade dos corpos-de-prova do "granito" Desert Storm, os valores de perda de massa de abrasivos apresentaram uma distribuição mais heterogênea. Porém, o abrasivo \#36 mesh foi, também neste caso, o que mostrou a menor perda (Figura 4.156).

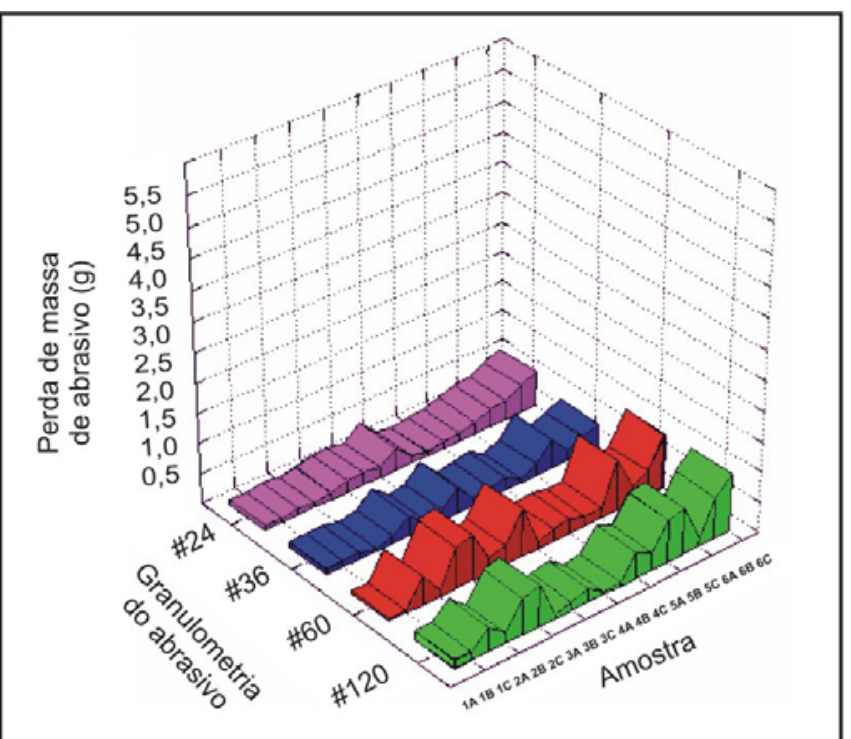

Figura 4.156 - Gráfico em linha mostrando taxas de desgaste dos abrasivos no "granito" Desert Storm ao longo das etapas de desgaste com as granulometrias de abrasivo 24, 36, 60 e 120 mesh.

O "granito" Verde Labrador foi o material que apresentou o maior brilho entre as rochas coletadas na indústria. Tal rocha foi a que apresentou, analisando todas as dez etapas de desgaste e principalmente a partir do abrasivo \#120 mesh, maior consumo de abrasivo (Figura 4.157). O abrasivo \#36 mesh, que nas outras cinco rochas estudadas não apresentou relevante importância, nesta rocha mostrou taxas de desgaste consideráveis, principalmente nas condições operacionais mais severas. 


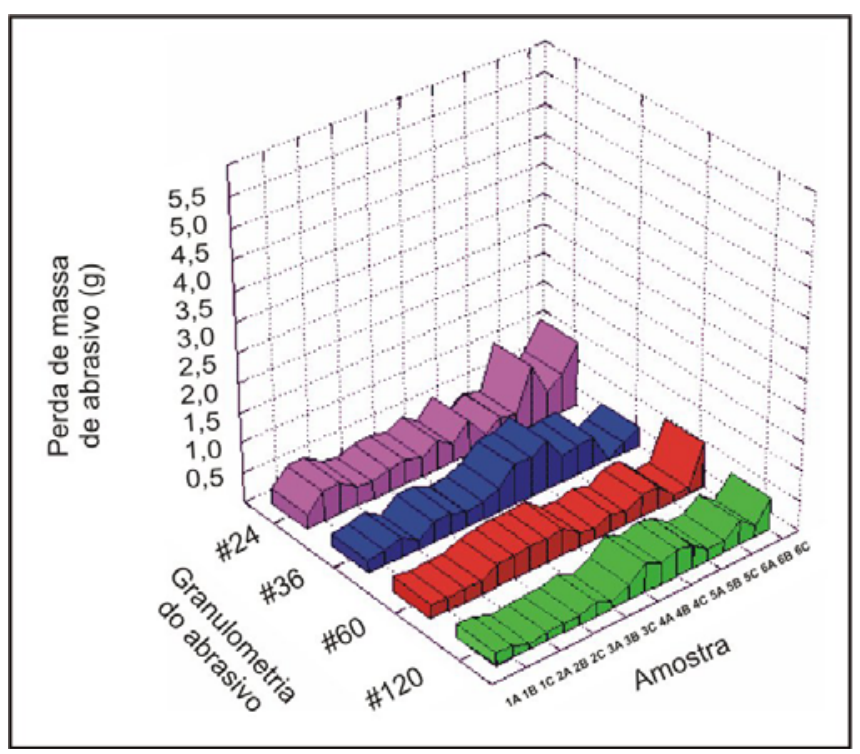

Figura 4.157 - Gráfico em linha mostrando taxas de desgaste dos abrasivos no "granito” Verde Labrador ao longo das etapas de desgaste com as granulometrias de abrasivo 24, 36, 60 e 120 mesh.

O gráfico de perda de massa de abrasivo do granito Vermelho Capão Bonito em muito se assemelha ao encontrado para o granito Vermelho Brasília (Figura 4.158).

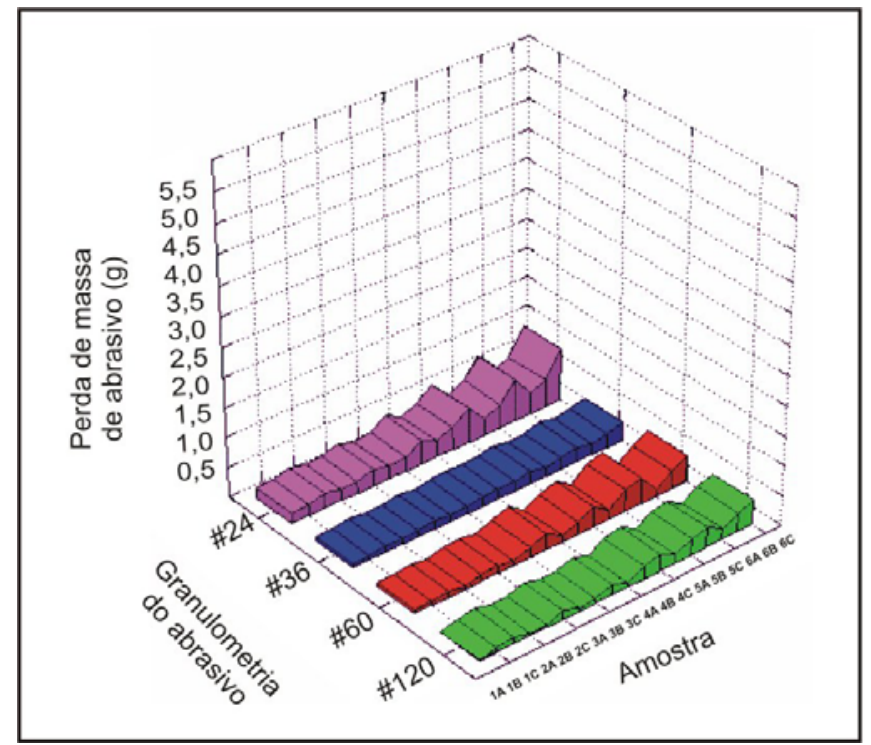

Figura 4.158 - Gráfico em linha mostrando taxas de desgaste dos abrasivos no granito Vermelho Capão Bonito ao longo das etapas de desgaste com as granulometrias de abrasivo 24, 36, 60 e 120 mesh.

A seguir serão mostrados os gráficos de perda de massa de abrasivo para as seis rochas nas outras seis etapas de desgaste (Figuras 4.159, 4.160, 4.161, 4.162, 4.163 e 4.164). 


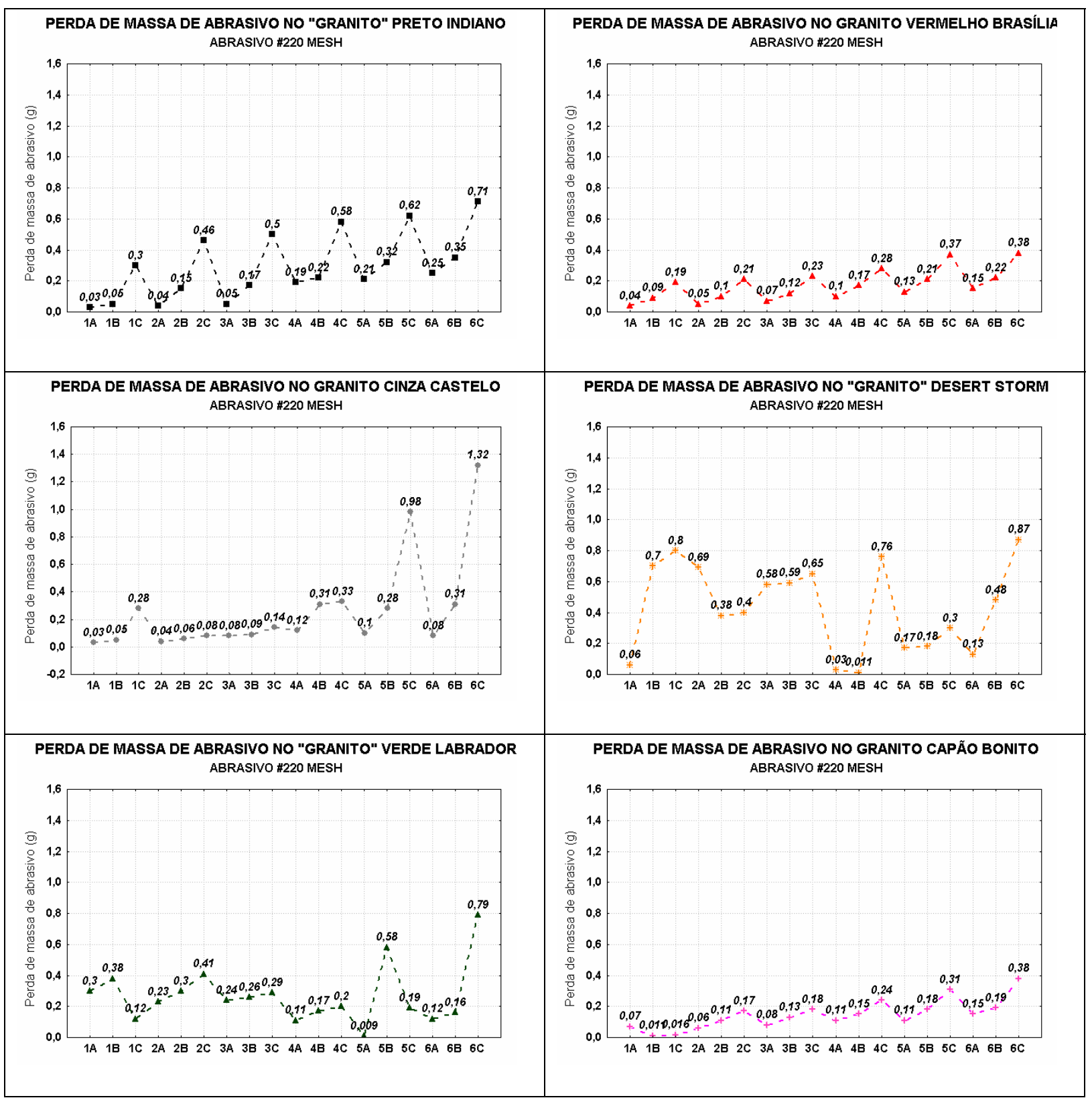

Figura 4.159 - Valores de perda de massa de abrasivo nas seis rochas estudadas na quinta fase de desgaste (220 mesh). 


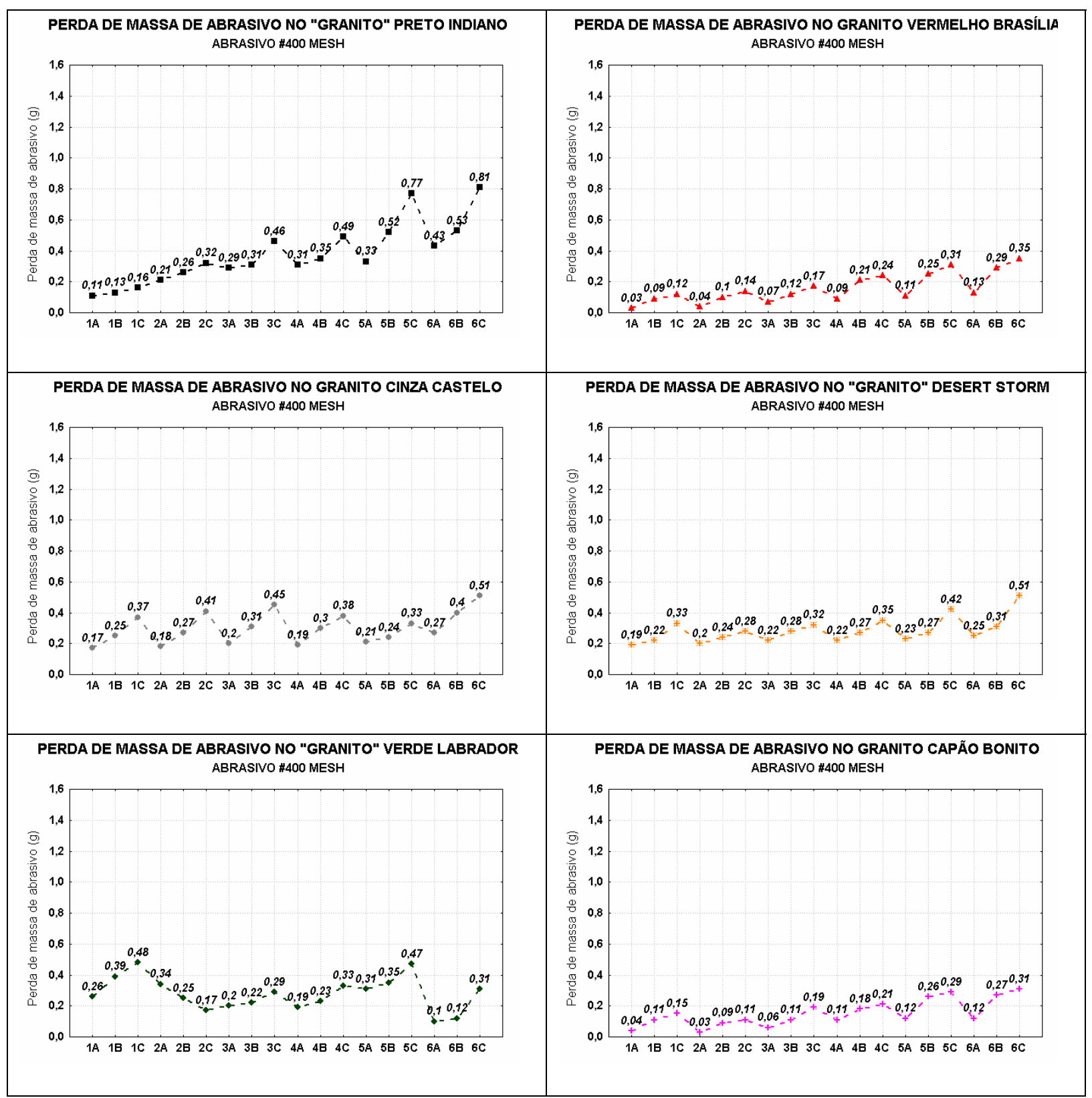

Figura 4.160 - Valores de perda de massa de abrasivo nas seis rochas estudadas na sexta fase de desgaste (400 mesh). 


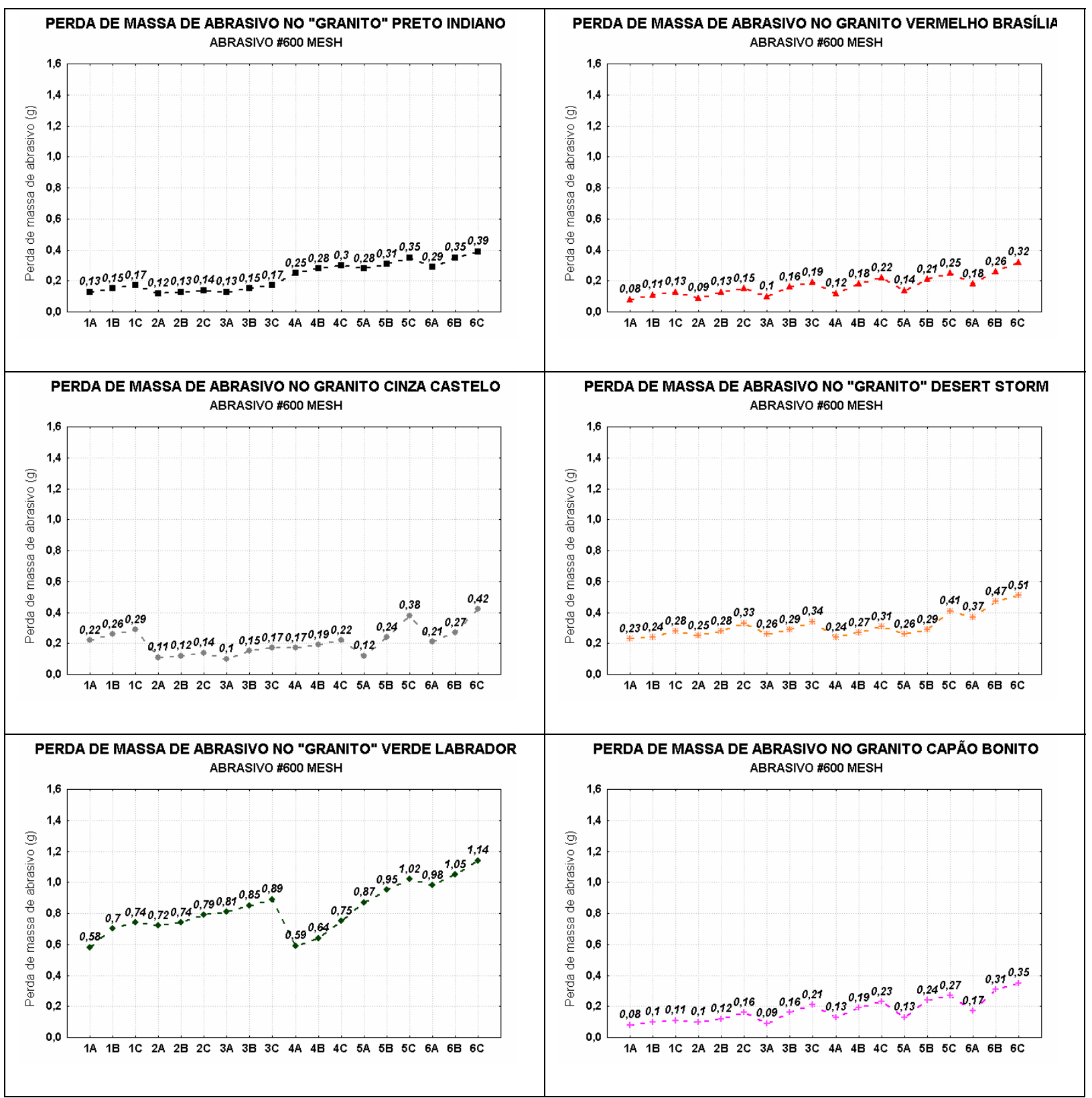

Figura 4.161 - Valores de perda de massa de abrasivo nas seis rochas estudadas na sétima fase de desgaste (600 mesh). 


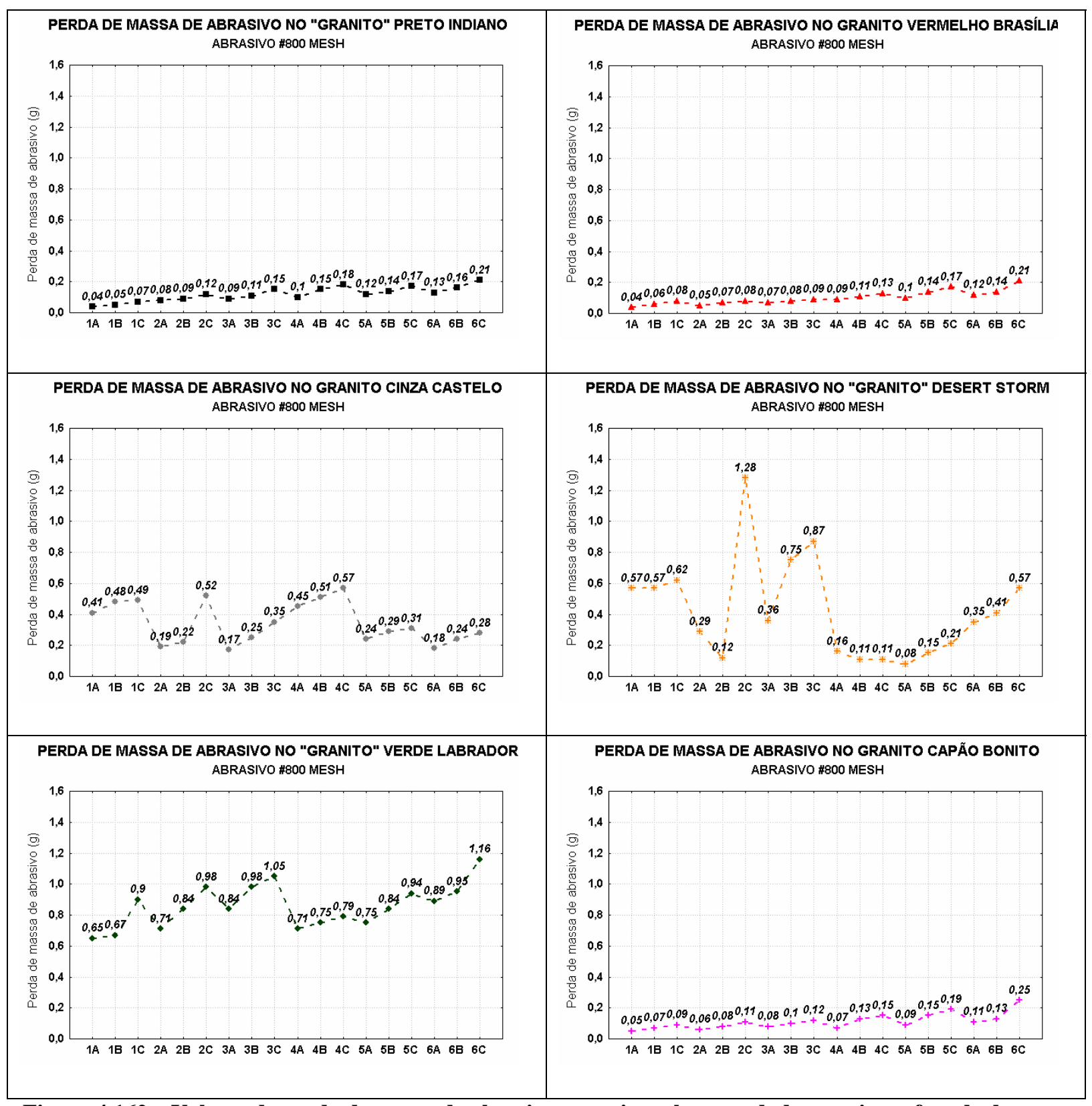

Figura 4.162 - Valores de perda de massa de abrasivo nas seis rochas estudadas na oitava fase de desgaste (800 mesh). 


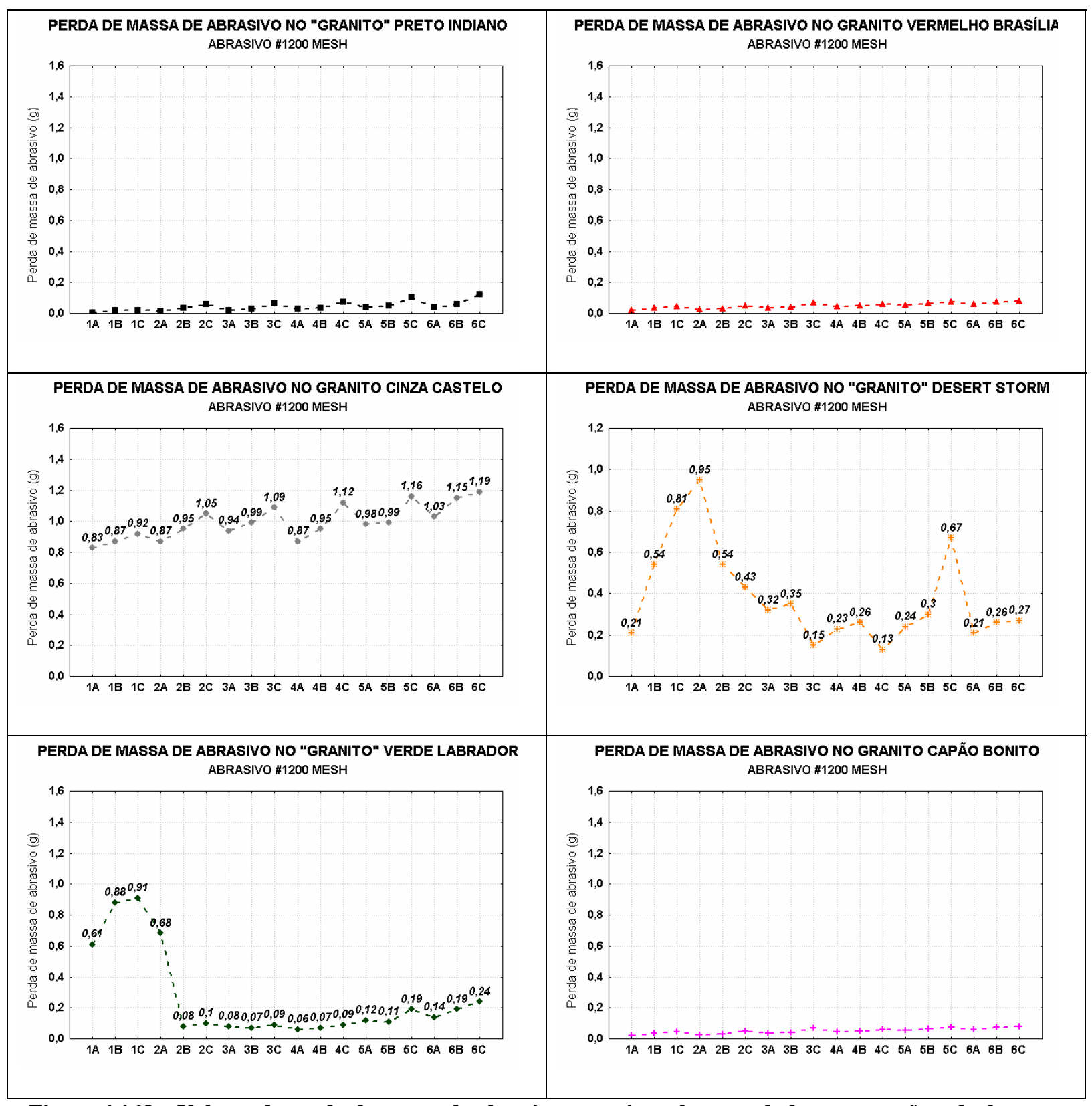

Figura 4.163 - Valores de perda de massa de abrasivo nas seis rochas estudadas na nona fase de desgaste (1200 mesh). 


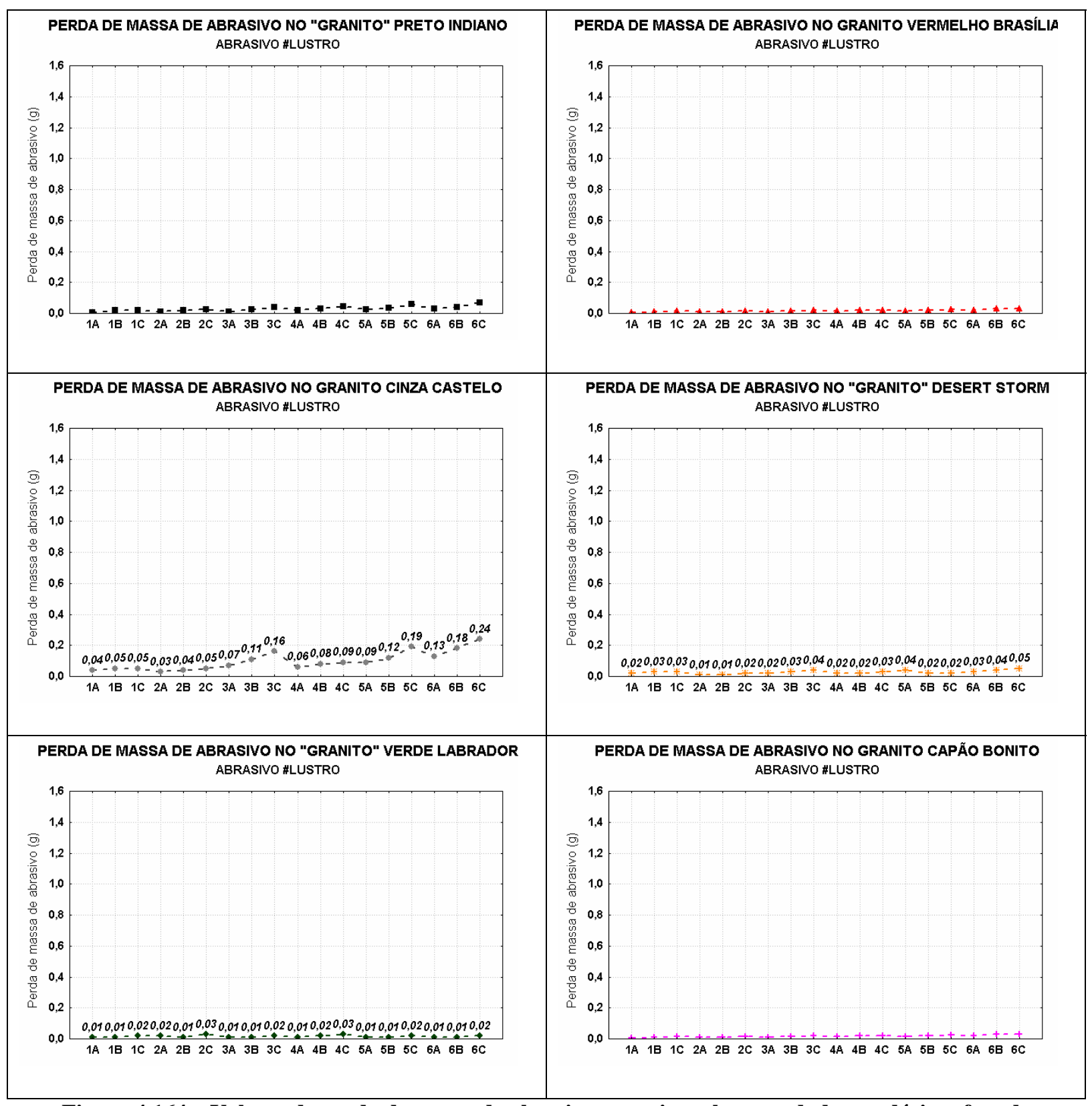

Figura 4.164 - Valores de perda de massa de abrasivo nas seis rochas estudadas na décima fase de desgaste (lustro).

De acordo com o apresentado nos gráficos é possível deduzir que:

- A taxa de consumo de abrasivo é muito influenciada pelo grau de anisotropia da rocha e pela granulometria do abrasivo. Quanto mais anisotrópica for a rocha maior a probabilidade de ocorrência de desgaste abrasivo por fadiga, devido a variação composicional da rocha.

- A princípio, o maior consumo de abrasivo redunda em melhor qualidade do produto final, visto que sugere uma melhor (ou ideal) interação entre o abrasivo e a rocha. Como 
exemplo desta afirmação tem-se o caso do "granito" Verde Labrador, que apresentou o maior brilho entre as rochas estudadas e também uma das maiores taxas de desgaste de abrasivo nas últimas seis fases de polimento. A relação entre as perdas de massa da rocha e do abrasivo pode vir a mostrar a situação mais adequada em termos das variáveis do processo, na qual se obtém a melhor qualidade e ao mesmo tempo o menor custo. Entretanto, são necessários estudos posteriores voltados para a definição da situação ideal entre consumo de abrasivo e qualidade final em escala real.

De acordo com o modelo analítico proposto por RABINOWICZ (1966) para definir o desgaste abrasivo em metais, tem-se:

$$
W=d^{2} \cdot \cot \alpha \cdot S \quad \text { (1) onde: }
$$

$\mathrm{W}$ - volume de material removido;

d - Profundidade da indentação;

$\alpha$; - ângulo do cone;

$\mathrm{S}$ - distância percorrida pelo indentador cônico.

A carga exercida pelo abrasivo $\left(\mathrm{F}_{\mathrm{N}}\right)$ sobre o material é o produto entre a área produzida por uma indentação e o limite de escoamento do material sobre a indentação (dureza, H).

$$
\begin{aligned}
& F_{N}=0,5 \cdot \pi \cdot(d \cdot \cot \alpha)^{2} \cdot H \\
& \quad d=\left[F_{N} /(0,5 \cdot \pi \cdot H)\right]^{1 / 2} / \cot \alpha \quad(3), \text { onde: }
\end{aligned}
$$

$\mathrm{F}_{\mathrm{N}}$ - carga individual da partícula abrasiva; 
$\alpha$ - Ângulo de ataque da partícula abrasiva na superfície a ser desgastada;

$\mathrm{H}$ - limite de escoamento do material sobre a indentação.

Substituindo $d$ da eq.(1) na eq.(3) é obtida a perda volumétrica de material em função da carga, da forma do abrasivo e da distância percorrida por ele:

$$
W=(2 . S \cdot \operatorname{tg} \alpha / \pi \cdot H) \cdot F_{N}
$$

O desgaste total do material pode ser então determinado a partir da somatória das perdas volumétricas de massa causadas por cada uma das partículas abrasivas:

$$
W_{\text {tot }}=\sum W=(2 \cdot \operatorname{tg} \alpha / \pi \cdot H) \cdot \sum F_{N}
$$

Para futura aplicação de um modelo analítico visando a previsão das taxas de desgaste em material rochoso é promissora, a tentativa da troca do limite de escoamento $(\mathrm{H})$, exclusivo de materiais metálicos, pela microdureza Knoop ou então a resistência à compressão uniaxial. De modo abrangente, o desgaste abrasivo verificado no polimento de rochas ornamentais pode ser representado como sendo função de:

$$
W=\int H, \delta, G a, c \quad \text { onde: }
$$

$\mathrm{W}$ - Volume de material rochoso retirado;

$\mathrm{H}$ - Dureza da rocha (knoop);

$\delta$ - Grau de anisotropia da rocha (textura/estrutura);

$\mathrm{Ga}$ - Granulomentria do abrasivo;

c - Condições operacionais.

Tais parâmetros devem estudados em conjunto, o que configura um tribossistema, sendo que para a obtenção de um modelo analítico que corresponda à realidade 
operacional na indústria, se faz necessário o melhor desenvolvimento deste modelo de modo contínuo com vista à obtenção de um banco de dados onde seja possível tratar tais informações e assim definir com mais segurança as situações ideais de desgaste em função de cada tipo rochoso.

\subsubsection{MEDIÇÃO DO BRILHO DOS CORPOS-DE-PROVA ENSAIADOS NO}

\section{EQUIPAMENTO SPR}

A medição do brilho dos corpos-de-prova utilizados no ensaio SPR (Figuras 4.165 e 4.166) processou-se com o auxílio de um glossmeter, sendo os resultados colocados numa curva de freqüência acumulada, com vista a obter um padrão de brilhos para as rochas estudadas considerando todas as condições operacionais. Nos gráficos apresentados, a seguir, foram plotados linha de tendência, juntamente com a equação da reta e o coeficiente de correlação. A interpretação dos resultados se baseou na análise da curva acima e abaixo da linha de tendência. Valores de brilho inferiores ao esperado ficaram situados abaixo da curva de tendência. Os valores que se encontram acima da curva de tendência pode-se confirmar que se configura a condição operacional ideal para se ter o melhor brilho com menor consumo de abrasivo, com menos tempo e menor velocidade de rotação. Quanto maior for a distância entre a curva de tendência e os valores situados a abaixo dela, pior e a condição operacional. 


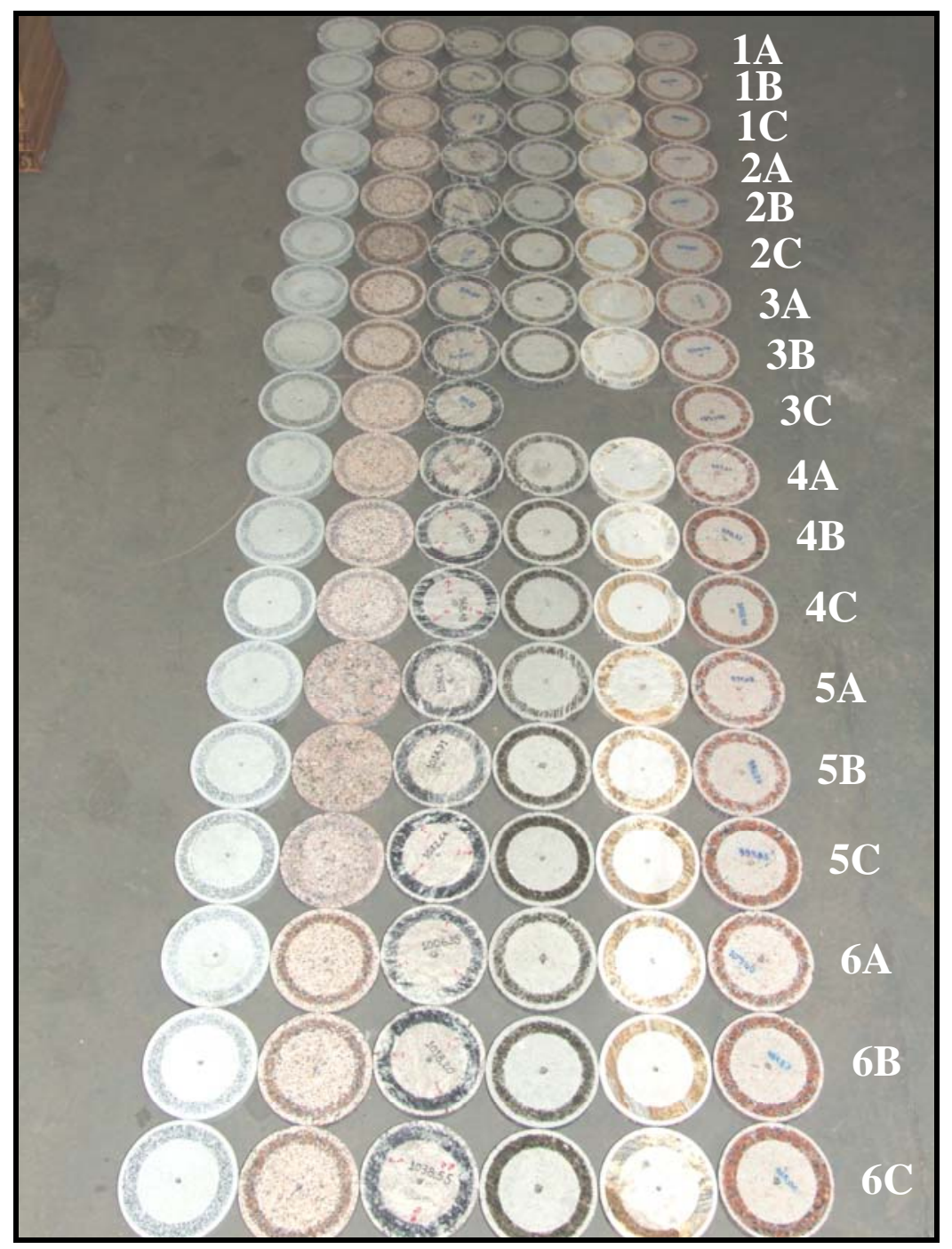

Figura 4.165 - Conjunto de todos os corpos-de-prova SPR.

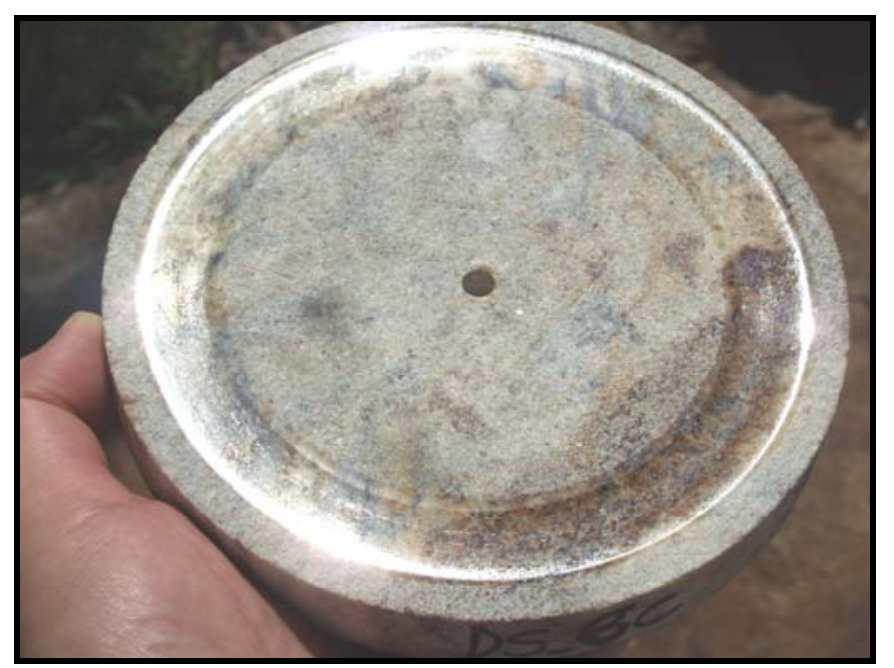

Figura 4.166 - Detalhe do corpo-de-prova após ensaio no SPR. 
A seguir serão mostradas as curvas de freqüência acumulada dos brilhos obtidos nas dezoito condições operacionais das seis rochas estudadas.

\section{“GRANITO” PRETO INDIANO}

Esta rocha apresentou a condição ideal de desgaste para brilhos superiores a curva de tendência a partir da situação 5B, que indica a condição de tempo de 4 minutos, carga de 2 bars e velocidade de 400 rpm (Figura 4.167).

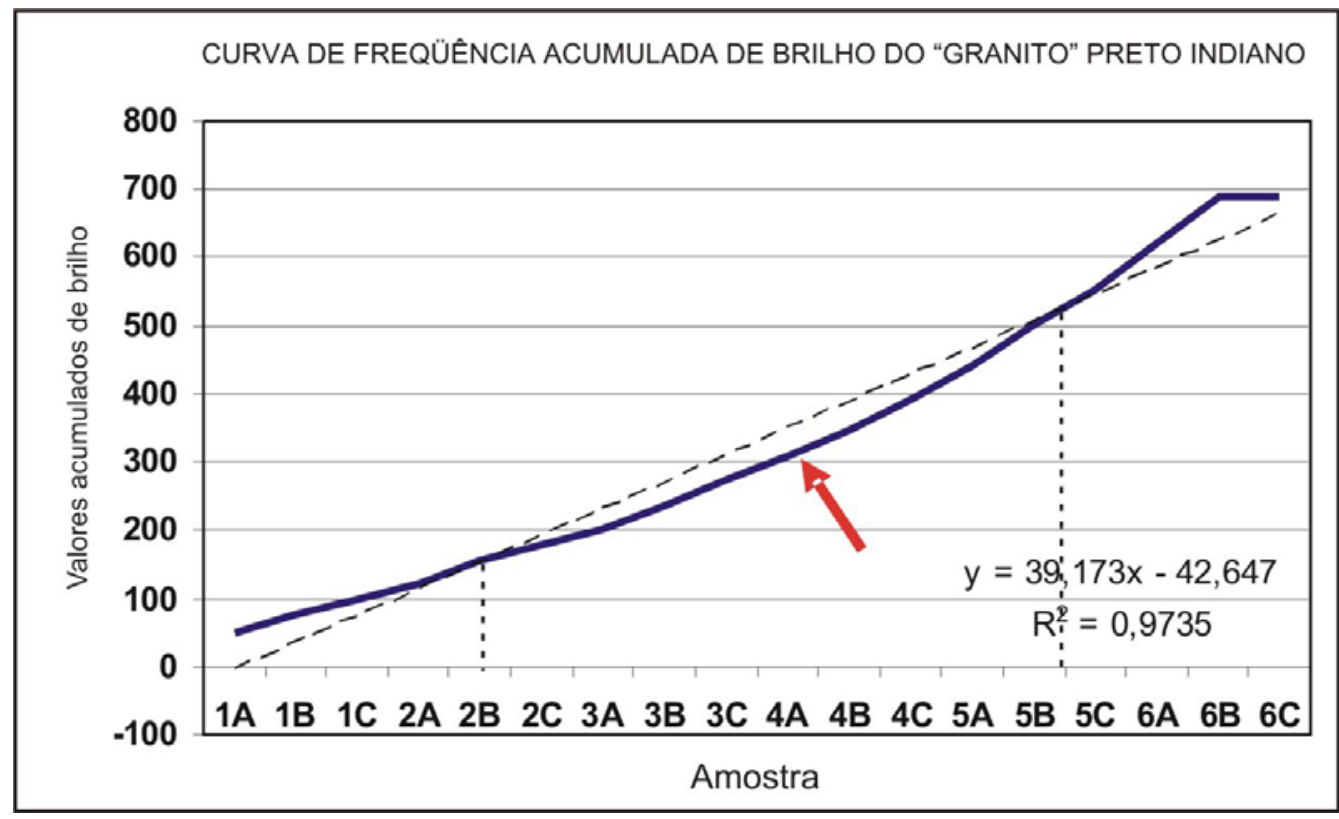

Figura 4.167 - Curva de freqüência acumulada dos valores de brilho para o "granito” Preto Indiano. A seta vermelha indica o intervalo de valores situados abaixo da curva de tendência.

\section{GRANITO VERMELHO BRASÍLIA}

O granito Vermelho Brasília mostrou a condição ideal de desgaste para brilhos superiores à curva de tendência a partir da situação 5B, que indica a condição de tempo de 4 minutos, carga de 2 bars e velocidade de $400 \mathrm{rpm}$ (Figura 4.168). 


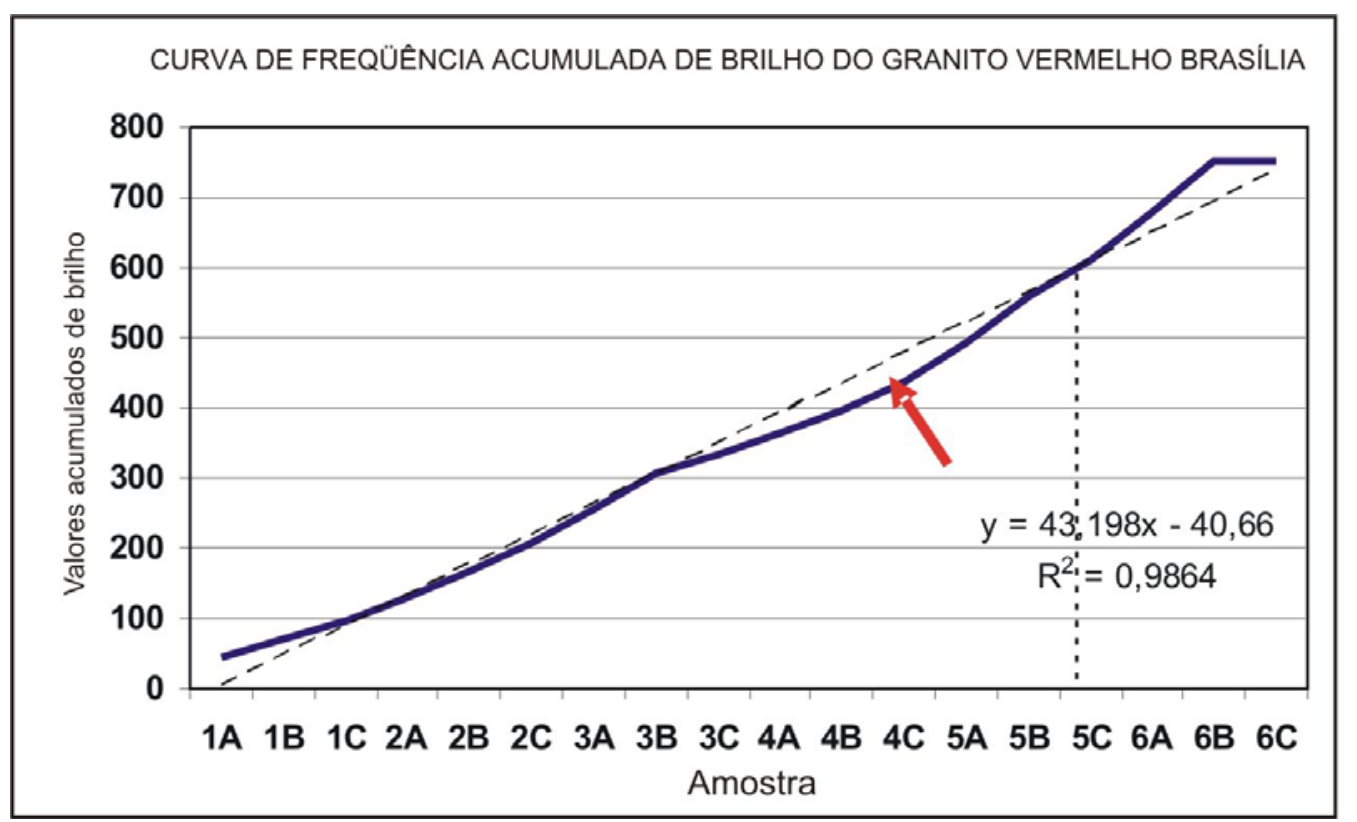

Figura 4.168 - Curva de freqüência acumulada dos valores de brilho para o granito Vermelho Brasília. A seta vermelha indica o intervalo de valores situados abaixo da curva de tendência.

\section{GRANITO CINZA CASTELO}

O granito Cinza Castelo mostrou a condição ideal de desgaste para brilhos superiores a curva de tendência a partir da situação $5 \mathrm{C}$, que indica a condição de tempo de 4 minutos, carga de 2 bars e velocidade de $600 \mathrm{rpm}$ (Figura 4.169).

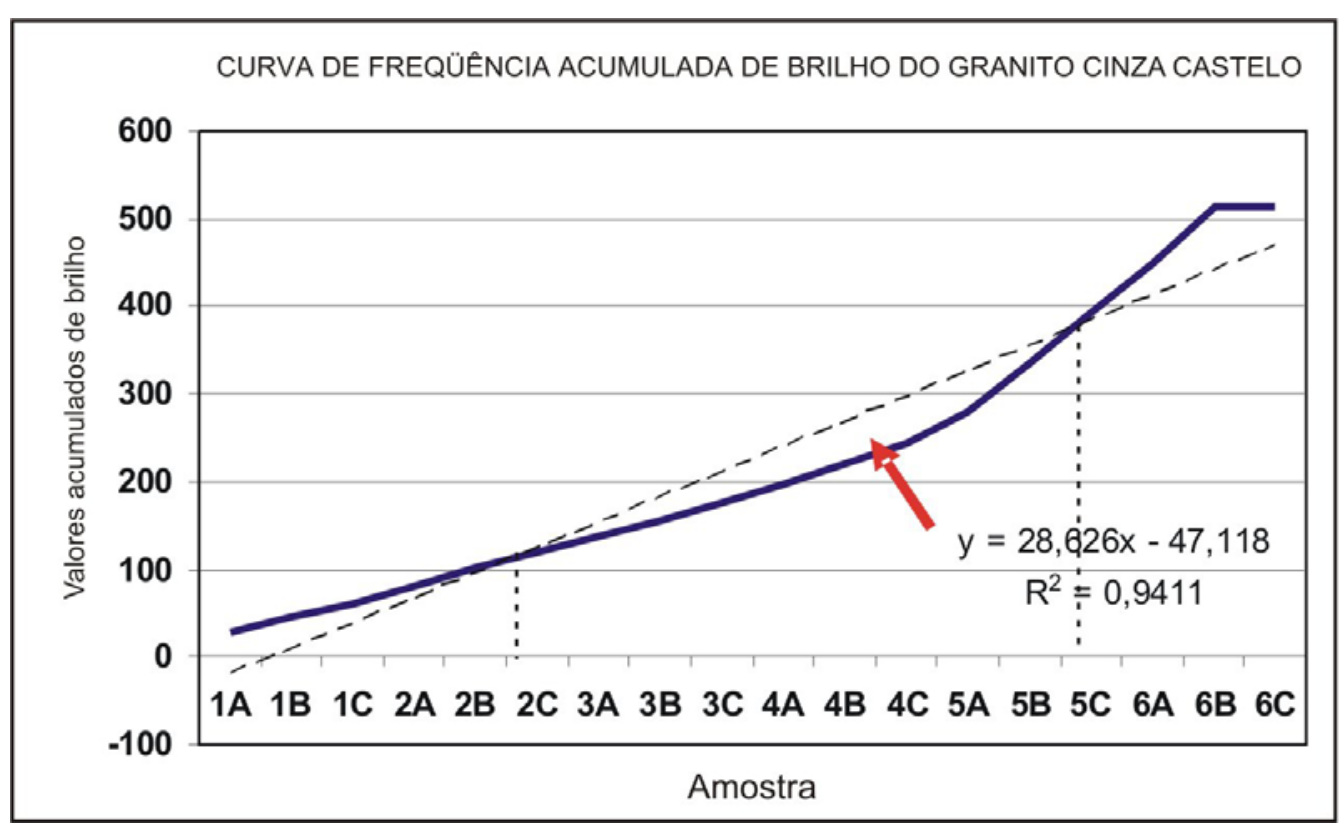

Figura 4.169 - Curva de freqüência acumulada dos valores de brilho para o granito Cinza Castelo. A seta vermelha indica o intervalo de valores situados abaixo da curva de tendência. 


\section{“GRANITO” VERDE LABRADOR}

Esta rocha mostrou a condição ideal de desgaste para brilhos superiores a curva de tendência a partir da situação $5 \mathrm{C}$, que indica a condição de tempo de 4 minutos, carga de 2 bars e velocidade de 600 rpm (Figura 4.170).

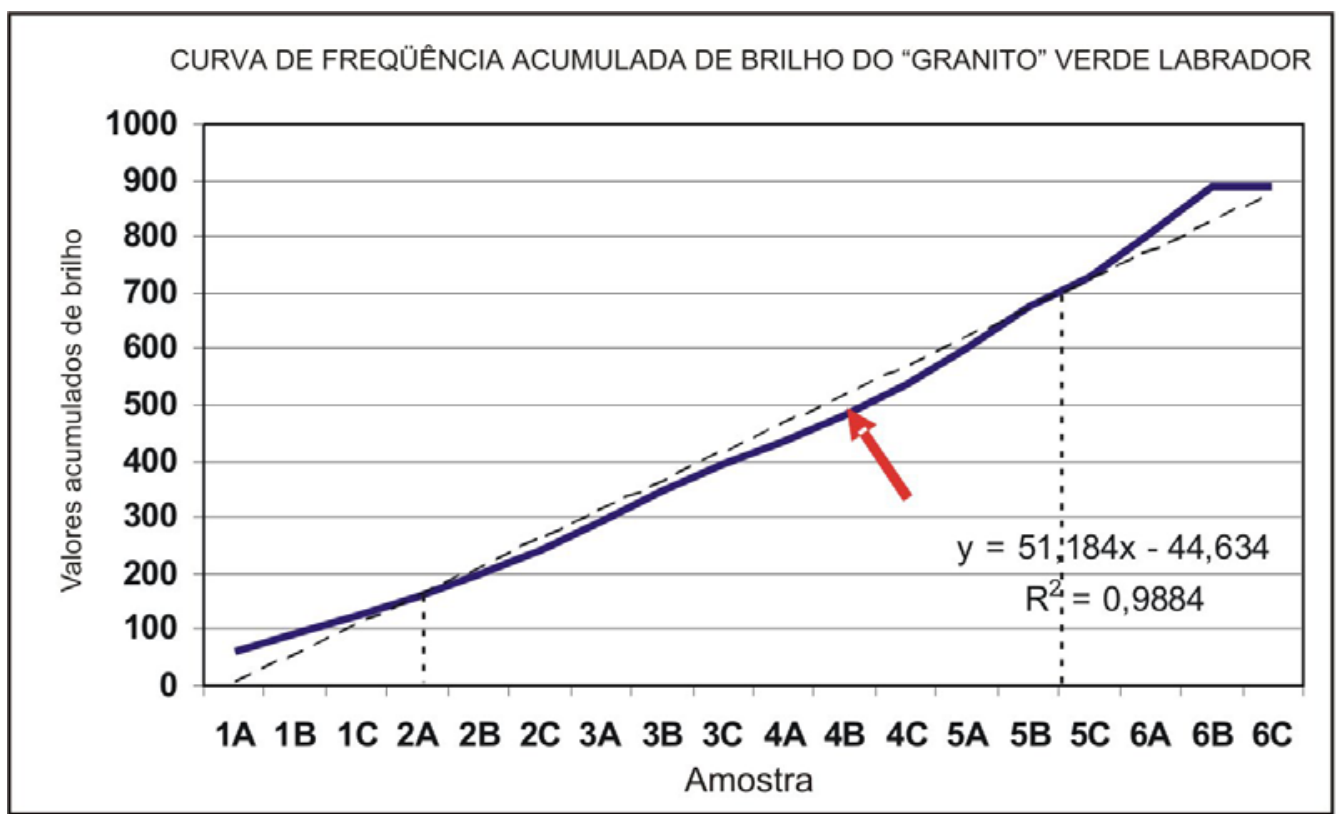

Figura 4.170 - Curva de freqüência acumulada dos valores de brilho para o "granito” Verde Labrador. A seta vermelha indica o intervalo de valores situados abaixo da curva de tendência.

\section{“GRANITO” DESERT STORM}

Esta rocha mostrou a condição ideal de desgaste para brilhos superiores a curva de tendência a partir da situação $5 \mathrm{~A}$, que indica a condição de tempo de 4 minutos, carga de 2 bars e velocidade de 200 rpm (Figura 4.171). 


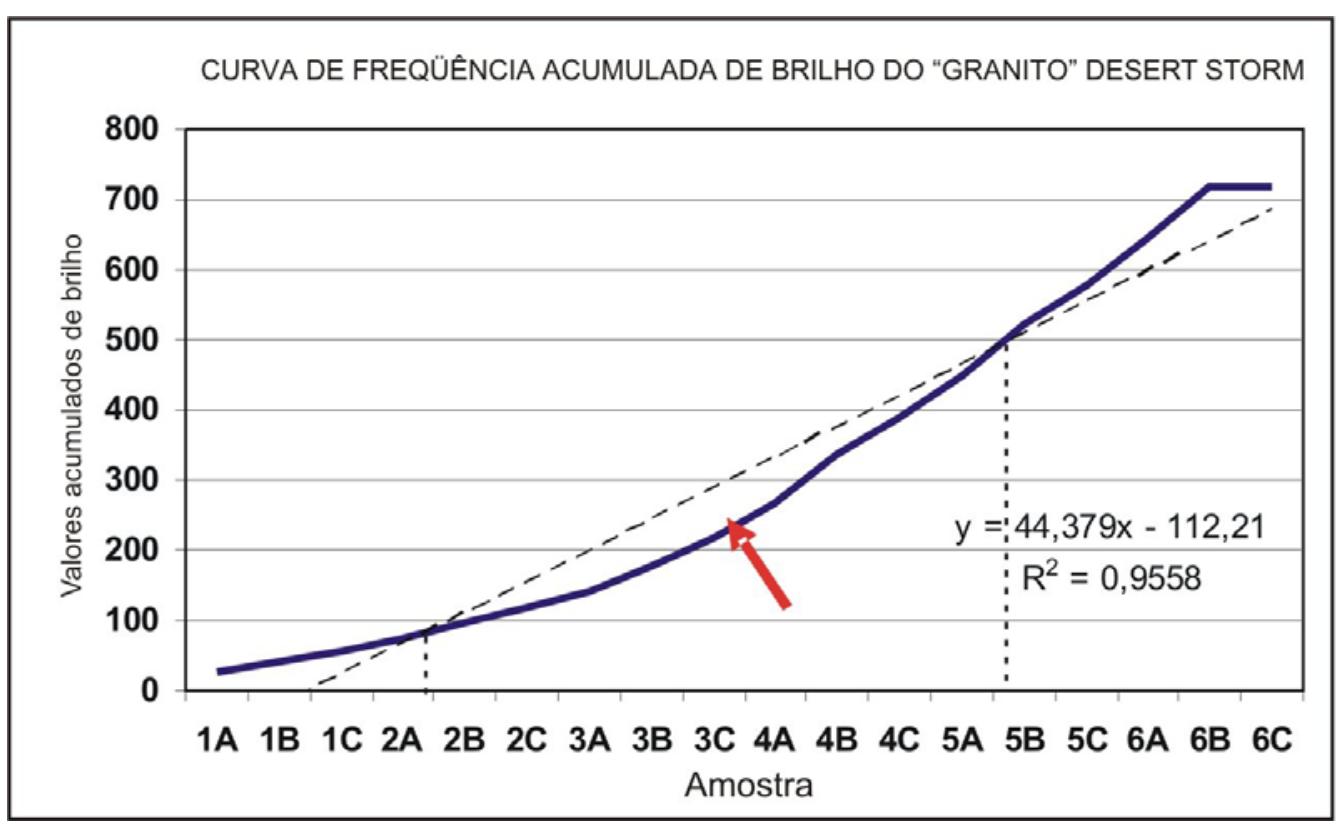

Figura 4.171 - Curva de freqüência acumulada dos valores de brilho para o "granito” Desert Storm. A seta vermelha indica o intervalo de valores situados abaixo da curva de tendência.

\section{GRANITO VERMELHO CAPÃO BONITO}

O granito Vermelho Capão Bonito apresentou a condição ideal de desgaste para brilhos superiores a curva de tendência a partir da situação $5 \mathrm{C}$, que indica a condição de tempo de 4 minutos, carga de 2 bars e velocidade de $600 \mathrm{rpm}$ (Figura 4.172).

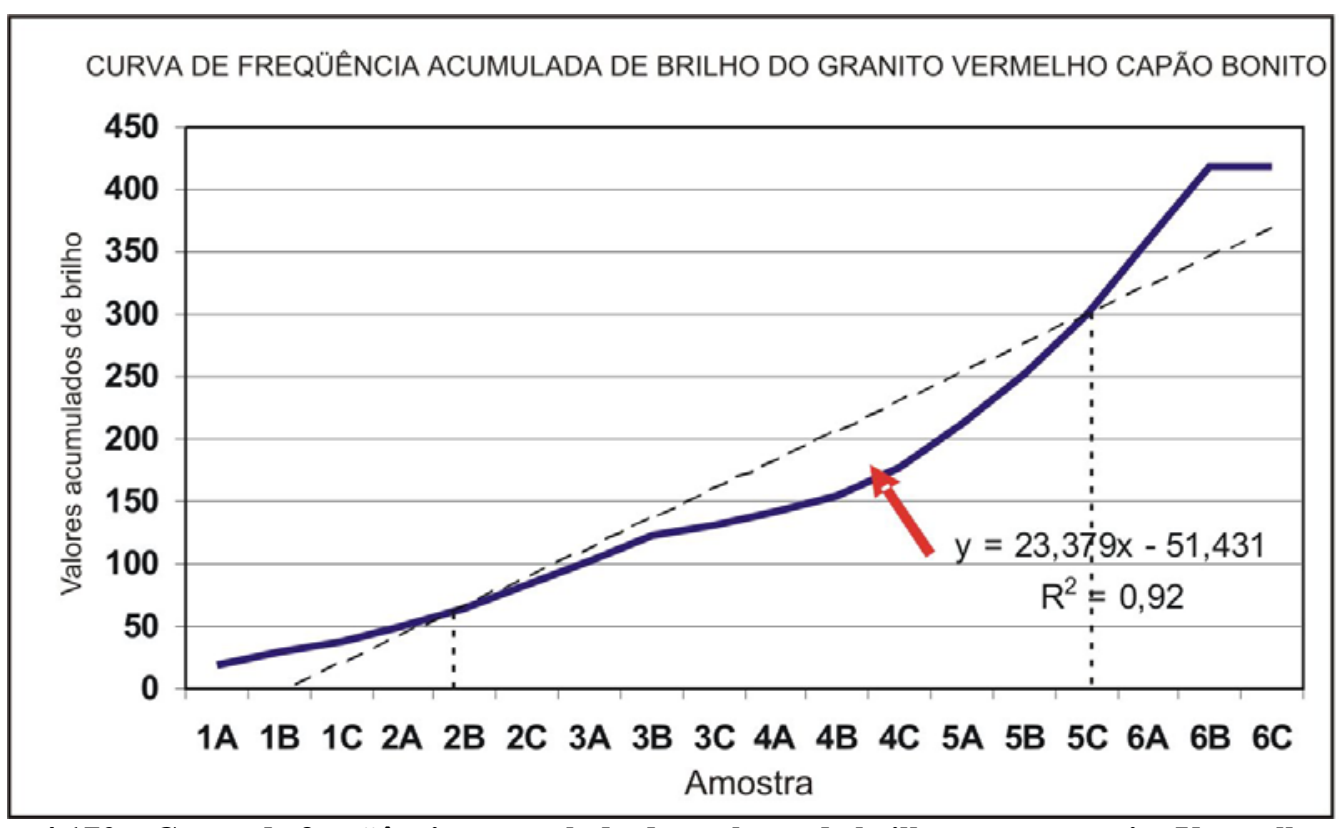

Figura 4.172 - Curva de freqüência acumulada dos valores de brilho para o granito Vermelho Capão Bonito. A seta vermelha indica o intervalo de valores situados abaixo da linha de tendência. 
Diante da constatação de que em condições distintas têm-se resultados diferentes, uma análise mais aprofundada do modelo analítico apresentado poderá contribuir para um melhor entendimento das relações entre a rocha e os outros dois elementos do sistema tribológico. 


\section{CONCLUSÕES}

O polimento de rochas ornamentais apresenta uma série de interações entre a rocha, os abrasivos e máquina de polir que a Indústria da Pedra ainda não considera.

De acordo com as informações adquiridas nesta pesquisa, teve-se a real constatação de que o processo polimento se insere num contexto tribológico com o desgaste do tipo abrasivo a dois corpos (rebolo abrasivo e rocha), sendo o terceiro elemento formador do sistema é a máquina de polir e suas variáveis operacionais.

O Simulador de Polimento de Rocha - SPR se mostrou eficiente na determinação da qualidade da superfície polida em contextos operacionais distintos.

Para determinados tipos rochosos a seqüência de abrasivos pode ser modificada com vista a agilizar o processo e economizar insumos. O abrasivo \#36 mesh não apresentou contribuição efetiva em cinco das seis rochas estudadas.

A proposta de um modelo analítico para previsão de taxas de desgaste ideais serviu para contextualizar o processo de polimento de rochas ornamentais em função dos principais fatores influentes no processo. Faz-se necessário o aprimoramento deste modelo, a se realizar com novas pesquisas voltadas a determinação dos pesos de cada fator proposto. 


\section{REFERÊNCIAS BIBLIOGRÁFICAS}

AGUS, M.; BORTOLUSSI, A.; CICCU, R. (1996) Abrasive-rock interaction in AWJ cutting. In: Gee C (ed) 1996 Jetting Technol., Mechan. Engng. Publ., London. Pp 509520.

AGUS, M.; BORTOLUSSI, A.; CICCU, R. (1995) Abrasive performance in rock cutting with AWJ and ASJ. In: Labus T J (ed) 1995 Proc. $8^{\text {th }}$ Amer. Water Jet Conf., Water Jet Techn.Ass., St. Louis, pp 31-48.

ALBERTIN, E. \& FILHO, F. A. (1994) Ensaios de desgaste de bolas de ferro fundido de alto cromo em moinhos de bolas de laboratório. In: Metalurgia \& Materiais, n 2428, 406-417p.

ALENCAR, C. R. A.; CARANASSIOS, A.; CARVALHO, D. (1996) Tecnologias de lavra e beneficiamento de rochas ornamentais. In: Federação das Indústrias do Estado do Ceará \& Instituto Euvaldo Lodi - IEL/CE. 225p.

AMERICAN SOCIETY OF METALS - ASM (2001) Surface engineering for corrosion and wear resistance. Davis \& Associates. USA, 279 p.

\section{AMERICAN SOCIETY FOR TESTING AND MATERIALS - ASTM C 880-89}

Standard test method for flexural strength of dimension stone. $3 p$.

AMERICAN SOCIETY FOR TESTING AND MATERIALS - ASTM D 523-94 Standard test method for specular gloss. $5 p$.

AMERICAN SOCIETY FOR TESTING AND MATERIALS - ASTM D 2845/95 Standard method for laboratory determination of pulse velocities and ultrasonic elastic constant of rocks. $4 p$ 
AMERICAN SOCIETY FOR TESTING AND MATERIALS - ASTM E 407-70 (Reapproved 1982) Standard methods for microetching metals and alloys. 505 $522 p$.

AMERICAN SOCIETY FOR TESTING AND MATERIALS - ASTM E 10 Standard Test Methods for Brinell of Metallic Materials, 5p.

AMERICAN SOCIETY FOR TESTING AND MATERIALS - ASTM E 18 Standard Test Methods for Rockwell Hardness and Rockwell superficial of Metallic Materials, $4 p$.

ASSOCIAÇÃO BRASILEIRA DE NORMAS TÉCNICAS - ABNT NB 93 - Rugosidade das superficies. Rio de Janeiro.

ASSOCIAÇÃO BRASILEIRA DE NORMAS TÉCNICAS - ABNT NBR 12763/92 Rochas para revestimento: determinação da resistência à flexão. Rio de Janeiro.

ASSOCIAÇÃO BRASILEIRA DE NORMAS TÉCNICAS - ABNT NBR 12766/92 Rochas para revestimento: determinação da massa específica seca aparente, porosidade aparente e absorção d' água aparente. Rio de Janeiro.

ASSOCIAÇÃO BRASILEIRA DE NORMAS TÉCNICAS - ABNT NBR 12767/92 Rochas para revestimento: determinação da resistência à compressão uniaxial. Rio de Janeiro.

ASSOCIAÇÃO BRASILEIRA DE NORMAS TÉCNICAS - ABNT NBR 12768/92 Rochas para revestimento: análise petrográfica. Rio de Janeiro.

ASSOCIAÇÃO BRASILEIRA DE NORMAS TÉCNICAS - ABNT NBR 12769/92 Rochas para revestimento: ensaio de congelamento e degelo conjugado à verificação da resistência à compressão. Rio de Janeiro. 
BAHADUR, S. \& BADRUDDIN, R. (1990) Erodent particle characteristics and the effect of particle size and shape on erosion. In: Wear 158, 189-208p.

BLASI, P.; COMAZZI, G.; FRISA MORANDINI A.; MARINI, P. (1995) Prenormative research concerning the measurement of polish of stone elements. In: $1^{\text {st }}$ International Congress of Natural Stones, Lisboa - Portugal. 19-22p.

CALLISTER, W. D. (2000) Ciência e Engenharia de Materiais: Uma Introdução. Ed. John Wiley \& Sons. 589p.

CENTRO TECNOLÓGICO DO MÁRMORE E GRANITO - CETEMAG (2003) Curso de polidor. Apostila, 21p.

CARPINETTI, L.C.R.; GONÇALVES FILHO, E.V.; PORTO, A.J.V.; JASINEVÍCIUS, R.G. (2000) Rugosidade Superficial. Conceitos e princípios de medição. EESC/USP Departamento de Engenharia Mecânica. 30p.

CAYLESS, M. A. \& MARSEDEN, A. M. (1991) Lamps and lighting. Edward Arnold, London. 351p

CHIODI FILHO, C. (2002a) Caracterização tecnológica das rochas ornamentais e de revestimento $-1^{\mathrm{a}}$ parte. In: Revista Pedras do Brasil no7 (Outubro), 24-26p.

CHIODI FILHO, C. (2002b) Caracterização tecnológica das rochas ornamentais e de revestimento $-2^{\mathrm{a}}$ parte. In: Revista Pedras do Brasil n ${ }^{\circ} 8$ (Novembro), 16-17p.

DANA, J. D. (1983) Manual de mineralogia. Rio de Janeiro, LTC - Livros Técnicos e Cinetíficos Editora S.A. 642p.

DEPARTAMENTO NACIONAL DE PRODUÇÃO MINERAL - DNPM (2006) Mineralnegócios: Guia do investidor no Brasil. Brasília - DF. 146p. 
ERDOGAN, M. (2000) Measurements of polished rock surface brightness by image analysis method. In: Engineering Geology 57. 65-72p.

FIORETI, A. (2003) Arquitetos querem mais informação. Entrevista na Revista Pedras do Brasil, no 16 (Julho), 16-17p.

FIRJAN/CIRJ/SESI/SENAI/IEL (1999) Estudo setorial de rochas ornamentais do Estado do Rio de Janeiro - Sumário executivo. Rio de Janeiro.

FRASCÁ, M. H. B. O.; MELLO, I .S. C.; QUITETE, E. B.; NAGATA, N.; CORTEZ, W. D. (2000) Rochas ornamentais e de revestimento do Estado de São Paulo. CDROM. Vol.2 - Publicação IPT no 2651.

FRASCÁ, M. H. B. O \& QUITETE, E. B. (2000) Estudos diagnósticos de patologias em rochas de revestimentos - Publicação IPT nº 2623.

FRAZÃO, E. B. (2002) Tecnologia de Rochas na Construção Civil. Ed. ABGE - Associação Brasileira de Geologia de Engenharia e Ambiental, 132p.

GODOY, A. M. (2003) Estudos geológico das rochas granitóides e metamórficas e suas aplicações como rochas ornamentais e de revestimento. Livre Docência. Departamento de Petrologia e Metalogenia do Instituto de Geociências e Ciências Exatas da Universidade Estadual Paulista - UNESP - Campus Rio Claro, 243p.

GONG, J. \& GUAN, Z. (2001) Load dependence of low-load hardness in ceramics: a modified PSR model. In: Materials letters, 47. 140-144p.

HAWORTH, R. D. Jr. (1949) The abrasion resistance of metals. Transactions of the A. S. M., v.41, 818-855p.

KASCHNER, D. (1996) Tecnologias para beneficiamento. In: II Encontro do Centro-Oeste Sobre Granitos, Mármores e Pedras Ornamentais, Goiânia-GO. 36p. 
KRANZ, R. L. (1983) - Micro cracks in rocks: A Review. In: Tectonophysics, 100. 449$480 p$.

LEE, J. D. (1996) Química inorgânica não tão concisa. Editora Edgar Blucher. 527p.

MISRA, A. \& FINNIE, I. (1983) An experimental study of three body abrasive wear. In: Wear, v. 85, 57-68p.

MOMBER, A. W. \& KOVACEVIC, R. (1998) Principles of Abrasive Water Jet Machining. Ed. Springer, 394p.

MORAIS, T. L. M. \& SUSTER, M. (2001) Uso de materiais abrasivos na indústria cerâmica. In: $45^{\circ}$ Congresso Brasileiro de Cerâmica. 12p.

MUMMERY, L. (1992) Surface Texture Analysis. The Handbook. Ed. Hommelwerke GmbH. $105 p$.

NOBLE, D. N. (1985) Abrasive wear resistance of hardfacing weld deposits. In: Metal Construction, v.17, $n^{\circ} 9$, 605-611p.

NOVASKI, O. (1994) Introdução a engenharia de fabricação mecânica. São Paulo, Editora Edgar Blucher.

ONODERA, T. F. \& KUMARA, A. H. M. (1980) Relation between texture and mechanical properties of crystalline rocks. In: Bull. Int. Assoc. Eng. Geol. 22, 173-177p.

QUITETE, E. B. (2002) Dureza knoop em rochas para revestimento: metodologia e correlação com desgaste abrasivo. Dissertação de Mestrado, Poli-USP. 70p.

QUITETE, E. B. \& RODRIGUES, E. P. (1998) Dureza knoop aplicada a rochas ornamentais. São Paulo. Publicação IPT 2561. 4p.

RABINOWICZ, E. (1966) Friction and Wear of materials. Cambridge, Massachusetts, John Wiley, $243 p$. 
SAFANIK, J. (1991) Garnet bohemia M. K.: a new abrasive material from Czecho-slovakia. In: Int. Conf. Geomechanics, Hradec n. M., poster presentation.

SANTANA, S. A. \& MELLO, J.D.B. (1994) Abrasão a três corpos de ferros fundidos brancos eutéticos. In: II Seminário Brasileiro Sobre Materiais Resistentes ao Desgaste, Fortaleza, CE, 15-38p.

SCOGNAMIGLIO, F. R. (1995) Abrasivos mais duros são realmente mais econômicos? In.: Revista Rochas de Qualidade, edição 120, Jan/Fev. 113p.

SINGH, P. \& RAMAKRISHNAN, P. (1996) Powder characterization by particle shape assessment. In. KONA, $n^{\circ} 14,16-30 p$.

STACHOWAIAK, G.W. \& BATCHELOR, A. W. (1993) "Engineering tribology". Amsterdam, Elsevier. 314 p.

STEDMAN, M. (1987) Basis for comparing the performance of surface-measuring machines. In: Precision Engineering, vol.9, 149-152p.

TOMITA, Y. \& EDA, H. (1996) A study of the ultra precision grinding process on a magnetic disk substrate - development of new bonding materials for fixed abrasives of grinding stone. In: Wear 195, 74-80p.

TYLCZAK, J. H. (1992) Abrasive wear. In: ASM Handbook Friction, lubrification and wear technology. V.18. 184-190p.

TUGRUL, A. \& ZARIF, I. H. (1999) Correlation of mineralogical and textural characteristics with engineering properties of selected granitic rocks from Turkey. In.: Engineering Geology 51. 303-317p. 
VILLASCHI FILHO, A. \& SABADINI, M. S. (2000) Arranjo produtivo de rochas ornamentais (mármore e granito) no Estado do Espírito Santo. Nota técnica 15, In: Instituto de Economia da Universidade Federal do Rio de Janeiro - IE/UFRJ. 132p.

WADELL, H. (1933) - Sphericity and roundness of rock particles. In: Journal of Geology 41, 316-331p.

XIE, Y. \& BHUSHAN, B (1996) Effects of particle size, polishing pad, and contact pressure in free abrasive polishing. In. Wear, 200, 281-295p.

ZUM-GAHR, K. H. (1987) Microstructure and wear of materials. Institute of Materials Technology. University of Siegen, Siegen, Federal Republic of Germany, v.10. 